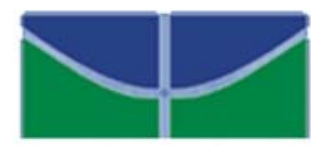

Universidade de Brasilia

Centro de Excelência em Turismo

\title{
Parque Estadual da Serra Dourada: Uma opção para o ecoturismo, seu cenário atual e perspectivas futuras
}

Monografia apresentada ao Centro de Excelência em Turismo da Universidade de Brasília como requisito parcial para a obtenção do certificado de Especialista em Ecoturismo

Aluna: Fernanda Rodrigues de Lima

Orientadora: Prof. Dra. Thereza Negrão

Brasília, DF.

Setembro de 2004. 
UNIVERSIDADE DE BRASÍLIA

Centro de Excelência em Turismo

Curso de Especialização em Ecoturismo

\title{
Parque Estadual da Serra Dourada: Uma opção para o ecoturismo, seu cenário atual e perspectivas futuras.
}

\author{
Aluna: Fernanda Rodrigues de Lima
}

Orientadora: Prf. Dra. Thereza Negrão

Banca Examinadora: Prof. Dra. Tânia Montoro

Brasília, DF.

Setembro de 2004. 
LIMA, Fernanda Rodrigues de. Parque Estadual da Serra Dourada:

Uma opção para o ecoturismo, seu cenário atual e perspectivas

Futuras. Brasília 2004.

$157 \mathrm{p}$. 


\section{DEDICATÓRIA}

Este projeto de monografia dedico aos meus pais, Gislaine Costa Lima e Donaldo Rodrigues de Lima, que permitiram a realização do curso de Especialização em Ecoturismo e que sempre me apóiam nos momentos de decisão, dando-me amor e carinho. 


\section{AGRADECIMENTOS}

A trajetória de elaboração dessa monografia só foi possível, pois contou com a colaboração de algumas pessoas. Registrar esses agradecimentos é uma forma de expressar minha gratidão para com as mesmas.

O meu sincero agradecimento à equipe docente do curso de Especialização em Ecoturismo da Universidade de Brasília, pelas contribuições científicas recebidas, e de maneira especial, a minha orientadora Thereza Negrão. Também aos colegas, pelo compartilhamento de informações.

As pessoas que tão prontamente me atenderam, ou seja, o consultor do SEBRAE/GO, o Sr. Joel Rocha; a artista plástica, a Sra. Goiandira Aires do Couto; a gerente de planejamento e pesquisa da AGETUR a Sra. Flávia Rabelo; o geógrafo e vereador, o Sr. Rodrigo Santana, o secretário municipal de cultura, turismo e meio ambiente da Cidade de Goiás, o Sr. Marco Antônio da Veiga, a bióloga e gestora de recursos naturais da Agência Ambiental, a Sra. Lívia Leite Santos e a presidente da associação de condutores e visitantes da Cidade de Goiás, a Sra. Otávia Xavier.

Ao meu namorado, João Luiz de Oliveira Lopes, pelo constante incentivo, troca de conhecimentos e generosidade, aos turistas e aos moradores da Cidade de Goiás pela receptividade e disposição em responder meus questionários. 


\section{EPÍGRAFE}

"É preciso resguardar em tempo a memória de uma cidade para que nossos descendentes não se queixem de nós mais tarde” (Cora Coralina).

"E quando das águas separadas aflorou Goyaz, há milênios, ficou ali a Serra Dourada” (Cora Coralina). 


\section{RESUMO}

Esse projeto de monografia analisou a viabilidade de implantação do ecoturismo no Parque Estadual da Serra Dourada, situado nos arredores da Cidade de Goiás. Para tanto, se fez necessário pesquisar junto aos turistas, sobre o interesse, para com essa atividade dentro dessa unidade de conservação, bem como, realizar um estudo de percepção junto aos moradores da cidade, como forma de verificar se são favoráveis a implantação da mesma, nessa área. O projeto revela ainda a situação atual da área do parque a fim de propor alternativas para o seu desenvolvimento.

Apresento também nesse projeto, a proposta de implantação do turismo regionalizado para a Cidade de Goiás, tendo como estudo de caso, o “Circuito da Estrada Real”, programa de turismo desenvolvido nos Estados de Minas Gerais, Rio de Janeiro e São Paulo. Dessa forma, sugiro que o ecoturismo no Parque Estadual da Serra Dourada seja um dos produtos a serem comercializados dentro de um roteiro, já existente, que é chamado de "Caminhos do Ouro”.

Palavras-chave (Serra Dourada, ecoturismo, viabilidade). 


\begin{abstract}
This project analysed the viability of introduction the ecotourism in Parque Estadual da Serra Dourada, situated in the outskirts of Cidade de Goiás. So that, was necessary to research with tourists, if they want to practice this activitiy inside this conservationt unity, as well as, a perception study with the local residents, to check if they are favorable to introduce this activity in this area. The project reveal this area present's situation, and so that, intend to offer some development alternatives.

I also present in this project, a proposal, of introctuction a regional tourism for Cidade de Goiás, having with case study, the "Circuito da Estrada Real”, a tourism program that is developed in the States of Minas Gerais, Rio de Janeiro and São Paulo. I suggest, that the ecoturism in Parque Estadual da Serra Dourada, could be just one of the products to be market inside an itinerary, that already exist, that is called "Caminhos do Ouro".
\end{abstract}

Key-Words (Serra Dourada, ecotourism, viability). 


\section{SUMÁRIO}

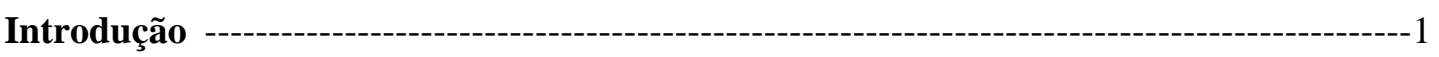

\section{Capítulo 1 - Passos Metodológicos}

1.1 Modalidade ----os

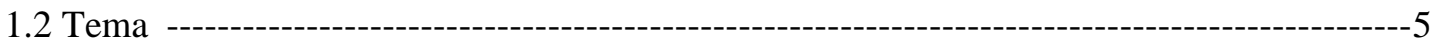

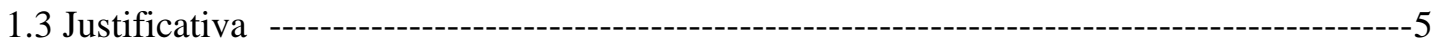

1.4 Problema --------------------------------------------------------------------------------------------------7

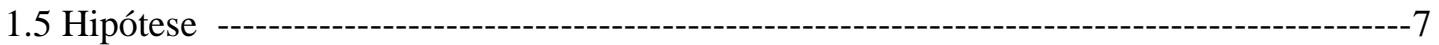

1.6 Objetivos

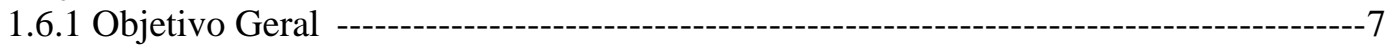

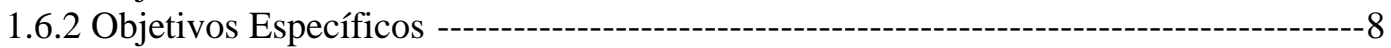

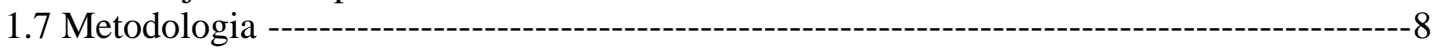

Capítulo 2 - Revisão da Literatura ---o- 11

Capítulo 3 - Cidade de Goiás

3.1 Contextualização Histórica e Geográfica do Município ---------------19

3.2 O Município Preservando Sua Memória e Fortalecendo Sua Identidade Local ---------- 33

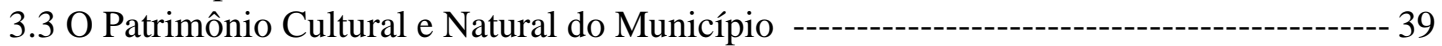

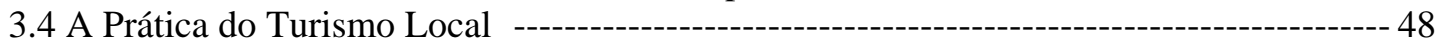

Capítulo 4 - Questões ambientais no Brasil e no Mundo

4.1 A Devastação do Meio Ambiente -------------- 59

4.2 As Conferências sobre Meio Ambiente e a Legislação Ambiental ------------------------- 62

4.3 O Surgimento das Unidades de Conservação (UCs) e do Sistema Nacional das

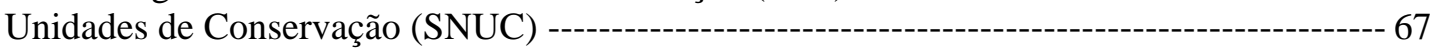

4.4 A Prática do Ecoturismo em Unidades de Conservação ------------------------------------- 71

Capítulo 5 - Parque Estadual da Serra Dourada

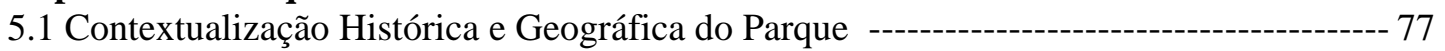

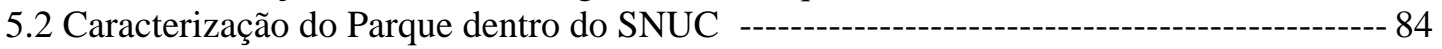

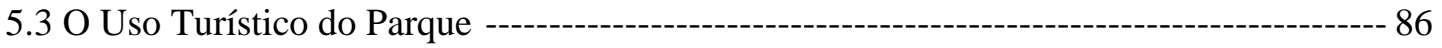

Capítulo 6 - Programa Caminhos para o Desenvolvimento Sustentável de Goiás ---- -88

Capítulo 7 - Benchmarking - Circuito da Estrada Real

7.1 Contextualização Histórica da Estrada Real ------------------------------------------------- 98

7.2 A Redescoberta dos Caminhos Reais -----on

Capítulo 8 - Pesquisa de Campo --_-109

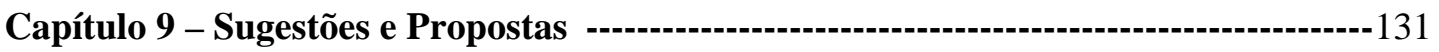

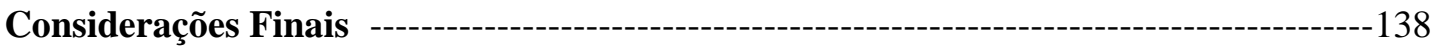

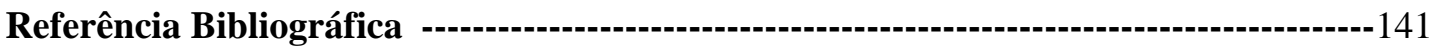

Anexos ------------------------------------------------------------------------------------------------------143

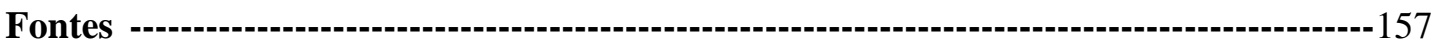




\section{LISTA DE ILUSTRAÇÕES}

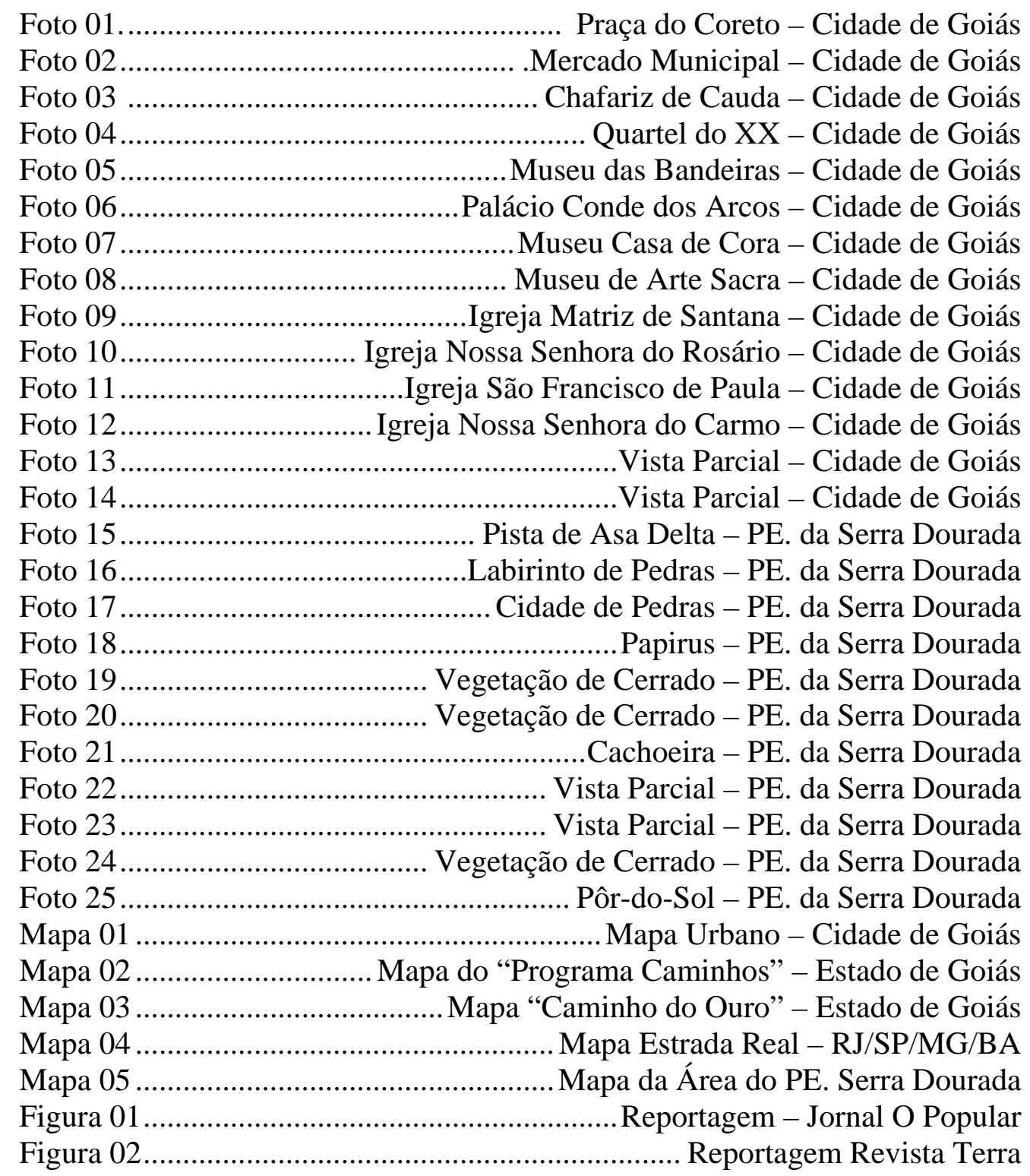




\section{LISTA DE ABREVIATURAS E SÍMBOLOS}

AGETUR

APA

CAT

COMTUR

CONAMA

CPDS

DAP

ECO-92

EIA

EMBRATUR

FICA

FUNATURA

IBAMA

IBDF

IBPC

ICCROM

Culturais

ICOMOS

IPHAN

IUCN

$\mathrm{Km}$

MPE

OMT

ONG

ONU

PARNA ou PN

PE

PNMT

PPA

RIMA

RPPN

SEBRAE

SEDUE

SEMA

SEMARH

SENAC

SEPLAN

SISNAMA

SNUC

SPHAN

UC

UFG

UNESCO
Agência Goiana de Turismo

Área de Proteção Ambiental Centro de Atendimento ao Turista - Conselho Municipal de Turismo Conselho Nacional de Meio Ambiente Comissão de Políticas de Desenvolvimento Sustentável da Agenda 21 Nacional - Departamento de Áreas Protegidas Conferência Mundial do Meio Ambiente e Desenvolvimento Estudo de Impacto Ambiental Instituto Brasileiro de Turismo - Festival Internacional de Cinema e Vídeo Ambiental Fundação Pró-natureza - Instituto Brasileiro de Meio Ambiente e Recursos Naturais Renováveis Instituto Brasileiro de Desenvolvimento Florestal - Instituto Brasileiro de Patrimônio Cultural --Centro Internacional de Estudos para a Conservação e Restauração de Bens Conselho Internacional de Monumentos e Sítios Instituto do Patrimônio Histórico e Artístico Nacional União Internacional para a Conservação da Natureza Quilômetro Micro e Pequenas Empresas Organização Mundial de Turismo Organização Não-Governamental - Organização das Nações Unidas Parque Nacional -Parque Estadual Programa Nacional de Municipalização do Turismo Plano Plurianual Relatório de Impacto do Meio Ambiente Reserva Particular do Patrimônio Natural Serviço Brasileiro de Apoio às Pequenas e Micro Empresas Ministério do Desenvolvimento Urbano e Ecologia do México - Secretaria Especial de Meio Ambiente Secretaria do Meio Ambiente e Recursos Hídricos - Serviço Nacional de Aprendizagem Comercial - Secretaria Estadual de Planejamento Sistema Nacional de Meio Ambiente Sistema Nacional de Unidades de Conservação Serviço do Patrimônio Histórico e Artístico Nacional Unidade de Conservação Universidade Federal de Goiás Organização das Nações Unidas para Educação, Ciência e Cultura 


\section{INTRODUÇÃO}

O Turismo é uma atividade que a partir da década de 1960, tem apresentado índices consideráveis de crescimento, e se mostrado bem rentável em termos socioeconômicos e culturais. Segundo Petrochi (2002, p.11) “o mercado internacional do turismo evoluiu de 25 milhões de visitantes, em 1950, para 500 milhões, em 1990”. Através de dados do Instituto Brasileiro de Turismo (Embratur), pode-se verificar que somente observando entre os anos de 1992 e 2002, esse crescimento aumentou de 503 milhões de turistas para 688 milhões em escala mundial e particularmente no Brasil, esse índice passou de 1,7 milhões para 4,8 milhões de pessoas viajando no decorrer desses anos.

Com o desenvolvimento da tecnologia, que possibilitou a construção de motores a vapor para equipar navios e locomotivas, ocasionando também a evolução dos meios de transporte, bem como, as técnicas sofisticadas de engenharia e arquitetura, permitindo a construção de torres de observação, como por exemplo, a Torre Eiffel em Paris (França), a construção de ferrovias e portos, deu-se início a um processo de investimentos neste ramo de atividade.

A consolidação do capitalismo trouxe consigo o surgimento de uma classe social (classe média) com necessidades e recursos financeiros próprios, e para tanto, foi necessário atender esta nova gama de consumidores. Isto permitiu a ampliação do setor de prestação de serviços e especialmente favoreceu o surgimento do turismo. 
Além da tecnologia mencionada, as mudanças econômicas, ou seja, a riqueza, agora proveniente não só das fazendas e comércio, mas também das indústrias, as mudanças políticas, as próprias relações sociais e culturais também transformaram as sociedades pósindustriais. A cultura, o esporte, as artes, o lazer e a preocupação com a qualidade de vida também vieram beneficiar o desenvolvimento do turismo. Observamos então, que as pessoas estão sentindo necessidade cada vez mais de um estilo de vida diferenciado em que possam ter contato com lugares e culturas diversas.

Uma particularidade do turismo é o que o consumidor deve dirigir-se para o próprio lugar da produção turística, ou seja, exige-se o deslocamento para consumir o produto turístico, além é claro, de habitualmente pagar pelo serviço antes mesmo de consumí-lo, daí a importância de profissionais especialmente capacitados, já que, o único valor residual do produto turístico após o consumo, é a experiência ou a satisfação de realizar uma viagem desejada.

Para produzir e distribuir o produto no mercado é necessário um conjunto de equipamentos e serviços de alojamento, alimentação, transporte, lazer e recreação. Todos estes equipamentos mencionados devem estar em comum acordo com a própria infra-estrutura da região, na qual irá se desenvolver a atividade, ou seja, uma cidade com potencial turístico deve ter estrutura de acesso com estradas bem conservadas e sinalizadas, sistemas de transporte em bom estado de manutenção, segurança, sistema de água e energia, centros de informações turísticas, e claro, uma rede de atrativos capazes de atender os visitantes.

Evidenciando o crescimento do turismo na sociedade contemporânea e a potencialidade do Estado de Goiás como pólo receptor dessa atividade, é imprescindível que o Estado esteja preparado para atender esta demanda. A Cidade de Goiás (antiga Goiás Velho), patrimônio mundial da humanidade, com população aproximada de 28 mil habitantes, localizada a 149 km de Goiânia e cerca de 320 km de Brasília, é uma das principais cidades turísticas do Estado, por isso, meu projeto terá como pano de fundo este município.

A Cidade de Goiás tem origem no Arraial de Sant’Ana, às margens do rio Vermelho, onde o bandeirante Bartolomeu Bueno da Silva, o Anhangüera, localizou grandes jazidas de ouro. Em 1739, foi dado o nome de Villa Boa de Goyaz e a cidade passou a desempenhar papel de destaque na ocupação do Brasil Central, durante os séculos XVIII e XIX. A 
existência de ouro encorajou a corrida para esse território isolado e a fundação de vilas, das quais Goiás era a mais importante. No ano de 1918 finalmente passou a se chamar Cidade de Goiás. Manteve-se como capital do Estado até 1937, quando esta foi transferida para Goiânia.

Quando da mudança da capital, a cidade de maneira quase imperceptível passou a ser chamada popularmente de Goiás Velho, isto porque, parecia que os habitantes do Estado haviam rompido de tal modo com a antiga e tradicional identidade goiana, o que de uma certa forma significava tanto um espírito supostamente arcaico, quanto o status perdido da antiga capital. Porém, os moradores da cidade, ficaram inconformados com o nome por remeter a idéia de que Goiânia significava progresso e Goiás atraso e decadência.

Hoje, Goiás conserva o calçamento em pedras irregulares, características urbanas originais e um rico acervo arquitetônico colonial. Além da arquitetura civil e religiosa e do acervo de suas igrejas, a cidade tem rica vida social e cultural e preserva importantes tradições.

Assim, escolhi como objeto de estudo analisar a viabilidade de implantação do ecoturismo no Parque Estadual da Serra Dourada, que está localizado nos arredores desse município, além de englobar também parte do território dos municípios de Mossâmedes e Buriti de Goiás. Com uma área de 30.000 hectares, o Parque Estadual da Serra Dourada é o segundo maior parque do Estado, possuindo vários atrativos e pontos de beleza cênica como cachoeiras, afloramentos rochosos e diversidade de cobertura vegetal e faunística, constituindo-se como um verdadeiro patrimônio ecológico para o Estado de Goiás.

Dessa forma, irei pesquisar junto aos turistas que freqüentam a cidade, se eles têm o interesse de praticar o ecoturismo no Parque Estadual da Serra Dourada, além disso, esse projeto também fará um estudo de percepção junto à comunidade receptora, ou seja, irá analisar se a população local mostra-se favorável ao desenvolvimento do ecoturismo no parque estadual em questão.

Caso essa pesquisa comprovar a viabilidade de implantação do ecoturismo, irei sugerir que este atrativo se desenvolva como um produto turístico inserido dentro do Programa “Caminhos do Ouro”, que é atualmente um dos roteiros turísticos do Estado de Goiás, e de 
autoria do Serviço Brasileiro de Apoio às Pequenas e Micro Empresas (SEBRAE/GO) e em parceria com a Agência Goiana de Turismo (AGETUR).

Entendo, que o atrativo Parque Estadual da Serra Dourada possa ser formatado em um produto ecoturístico o qual esteja relacionado diretamente ao Programa "Caminhos do Ouro", por estar localizado em plena Cidade de Goiás, que tem esse forte apelo histórico, além é claro, pelo fato de a própria serra ter sido percorrida em alguns trechos pelos antigos bandeirantes e tropeiros quando da colonização do Estado, ou seja, o turismo histórico, religioso e ecoturismo se juntam, e assim, percorrer por esses caminhos torna-se uma verdadeira volta ao passado.

Desse modo, o Estado de Goiás, de grande importância no cenário nacional, deve situar o turismo, e em especial o ecoturismo, como uma das atividades prioritárias para o seu progresso.

Enfim, a monografia está subdividida em nove capítulos. O capítulo 1 relata os passos metodológicos utilizados no decorrer da execução desse projeto, e em seguida, o capítulo 2 desenvolve uma abordagem ampla de todo o conteúdo desenvolvido, ou seja, uma revisão da literatura. Mais adiante, o capítulo 3 discorre sobre a Cidade de Goiás situando-a em um contexto histórico-geográfico e relatando algumas de suas particularidades, como por exemplo, o turismo que é desenvolvido no município.

O capítulo 4 expõe algumas idéias relacionadas às questões ambientais no Brasil e no mundo, para posteriormente, no capítulo 5 inserir o meu objeto de estudo, que é um relato mais detalhado do Parque Estadual da Serra Dourada e toda a atividade de ecoturismo que poderá ser desenvolvida no mesmo. O capítulo 6 faz um relato do Programa Caminhos para o Desenvolvimento Sustentável de Goiás, e sua relação com o turismo no Estado, enquanto que o capítulo 7 revela um pouco sobre o Circuito da Estrada Real, programa de turismo desenvolvido nos estados de Minas Gerais, São Paulo e Rio de Janeiro e que serve de modelo para esse projeto.

O capítulo 8, posteriormente demonstra por meio de gráficos a pesquisa de campo realizada e finalmente no capítulo 9 exponho algumas sugestões e propostas que poderão ser adotadas para a implantação do ecoturismo no Parque Estadual da Serra Dourada. 


\section{CAPÍTULO 1}

\section{PASSOS METODOLÓGICOS}

\section{1 - Modalidade}

Projeto de Pesquisa.

\section{2 - Tema}

Parque Estadual da Serra Dourada: Uma opção para o ecoturismo, seu cenário atual e perspectivas futuras.

\section{3 - Justificativa}

O ecoturismo é uma forma de turismo alternativo, uma vez que, se contrapõe ao turismo de massa, ou seja, aquele empreendido pela maioria dos viajantes e cujo fluxo ultrapassa os limites da capacidade de recepção de um local, não considerando importante às questões relacionadas a sustentabilidade. 
Assim, considero o ecoturismo como um segmento de mercado, isto porque, devido à necessidade de atender consumidores com comportamentos específicos e homogêneos, houve a necessidade de homogeneizar o mercado, o qual engloba o deslocamento responsável a ambientes naturais, e as pessoas que o praticam, podem contribuir para a conservação do meio ambiente, pois os recursos naturais representam a matéria-prima da atividade.

Além disso, esse segmento de mercado do turismo pode ter papel educativo, pois geralmente o ecoturista apresenta um forte desejo de aprender sobre a natureza em suas viagens, daí a grande importância da educação ambiental. A consciência ecológica deve estar vinculada não somente ao viajante, bem como a comunidade, aos empresários e ao setor público. Outro fator determinante é a inclusão das comunidades locais na atividade, permitindo assim a valorização da cultura e história regional. Por outro lado, não se deve limitar somente as oportunidades de emprego, mas envolver a população no processo completo de desenvolvimento, desde a fase de planejamento até a implantação e administração de projetos, por meio de consultas e parcerias.

Assim, englobando todas essas variáveis, o ecoturismo torna-se verdadeiramente promissor, e estará no caminho certo para a busca do desenvolvimento sustentável, tanto economicamente, ecologicamente, socialmente e até politicamente.

Sabendo que o estado de Goiás é privilegiado, com grande quantidade de municípios com potencial para o turismo, seja na ecologia, na cultura, na história, ou mesmo nos negócios, nada mais relevante do que pesquisar este mercado consumidor.

Por isso, o fato de escolher a Cidade de Goiás (antiga Goiás Velho), que conserva um valioso acervo arquitetônico colonial como parte essencial do meu projeto de monografia. A antiga capital do estado, encravada nos pés da lendária Serra Dourada, mostra o vigor do ciclo do ouro em Goiás, além de manter viva a nostalgia dos pioneiros. Em cada um de seus becos, ruas estreitas, muros de pedras, casarios e igrejas, a cidade se mostra rica em história. Histórias estas, traçando a memória estadual e do próprio Brasil.

Sendo assim, optei em específico pela Serra Dourada, que recentemente foi transformada no Parque Estadual da Serra Dourada, área de proteção, propícia para o desenvolvimento do ecoturismo. Para tanto, inicialmente se faz necessário conhecer os gostos 
e preferências do mercado, ou seja, verificar se a demanda que freqüenta a cidade teria o interesse de praticar atividades de lazer e recreação nesta área natural.

É necessário também fazer um estudo de percepção junto à comunidade receptora, a fim de verificar o interesse para com a atividade ecoturística. A carência de pesquisa junto a todos os atores sociais envolvidos no processo de fomento do turismo (comunidades, turistas, poder público e iniciativa privada) é um ponto favorável para a realização desta análise, bem como, o próprio crescimento da atividade no Estado de Goiás.

\section{4 - Problema}

Por que a Cidade de Goiás, que tem como símbolo de sua história a Serrra Dourada, não desenvolve nesta área natural o Ecoturismo de forma planejada?

\section{5 - Hipóteses}

- Falta de conhecimento das autoridades e da própria comunidade quanto aos benefícios advindos da atividade ecoturística.

- Interesse da comunidade local de manter intocada a Serra Dourada, que durante anos, foi explorada pela mineração.

- Os turistas que visitam a cidade podem ter interesse apenas pelos aspectos históricoculturais da região, não se interessando pelo lado ambiental.

\section{6 - Objetivos}

\subsection{1 - Objetivo Geral}

Conhecer o cenário atual do Parque Estadual da Serra Dourada, verificar a viabilidade da implantação do ecoturismo nessa área, bem como, sugerir que essa atividade se desenvolva vinculada ao Programa “Caminhos do Ouro”, um dos roteiros turísticos do Estado de Goiás. 


\subsection{2 - Objetivos Específicos}

- Verificar o nível de interesse das autoridades e da população local pelo ecoturismo;

- Conhecer os motivos do atual despreparo da região em receber visitantes interessados exclusivamente no turismo em áreas naturais;

- Levantar dados junto à demanda que freqüenta a cidade sobre quais práticas ecoturísticas gostariam de participar dentro do parque estadual.

\section{7 - Metodologia}

O aumento da atividade turística trouxe consigo a necessidade de formação de recursos humanos e para tanto, esses profissionais devem adquirir um mínimo de conhecimento sobre os procedimentos para a execução de pesquisas na área, pois isso, permitirá uma leitura crítica da realidade e um aprendizado prático da atividade. Sendo assim, a metodologia irá servir de referência no processo de busca de explicações em relação a problemas específicos.

Neste projeto, em um primeiro momento, a pesquisa será de caráter exploratório a fim de familiarizar-se com o fenômeno a ser estudado, ou seja, buscar descobrir um maior número de informações relevantes, e para isso será necessário:

- Realizar pesquisas bibliográficas em livros e artigos, além de pesquisa documental, como relatórios, dados de instituições públicas e documentos pessoais dos moradores da cidade verificando os aspectos históricos e culturais da Cidade de Goiás.

- Pesquisar sobre o que são unidades de conservação e situar o Parque Estadual da Serra Dourada, dentro desse contexto.

- Pesquisar sobre o "Programa Caminhos" proposto pelo SEBRAE/GO e pela AGETUR. 
- Será feita também pesquisa virtual (sites) coletando informações sobre o Circuito da Estrada Real, que é desenvolvido nos Estados de Minas Gerais, São Paulo e Rio de Janeiro.

O segundo estágio da pesquisa será a realização de uma análise descritiva. Inicialmente se fará um levantamento, a fim de conhecer a infra-estrutura básica e de apoio ao turista existente na Cidade de Goiás, no intuito de verificar o mercado e obter informações mais detalhadas sobre a demanda existente na cidade (conhecer o perfil do turista que visita a cidade). Esta análise descritiva será feita também no Parque Estadual da Serra Dourada, levantando dados históricos e físicos-geográficos da serra e os motivos da implantação do parque estadual.

Em seguida, serão feitas entrevistas parcialmente estruturadas, cujos temas serão particularizados e as questões preparadas antecipadamente, mas com plena liberdade quanto à retirada eventual de algumas perguntas e ao acréscimo de perguntas improvisadas.

Será entrevistado o gestor do SEBRAE/GO o Sr. Joel Rocha, um dos colaboradores do Programa Caminhos; Flávia Rabelo, gerente de planejamento e pesquisa da AGETUR; o geógrafo, ambientalista e vereador do Partido Verde (PV) da Cidade de Goiás o Sr. Rodrigo Santana; o Secretário Municipal de Turismo da Cidade de Goiás o Sr. Marco Antônio da Veiga; Lívia Leite Santos que é bióloga e gestora de recursos naturais do Departamento de Áreas Protegidas (DAP) da Agência Ambiental e que foi uma das técnicas responsáveis pelo estudo de viabilidade de implantação do parque; Otávia Xavier, presidente da Associação de Condutores e Visitantes da cidade e a artista plástica Goiandira Aires do Couto, que eternizou as belezas da serra através de seus quadros de areias coloridas.

Por fim serão aplicados os questionários (compostos de questões abertas e fechadas) com a comunidade, sobre o interesse em desenvolver o ecoturismo no Parque Estadual da Serra Dourada e com os turistas que freqüentam a cidade sobre suas motivações quanto à prática de atividades ecoturísticas nessa mesma região. 


\section{Pesquisa - questionários:}

A - População ou Universo: É a totalidade de indivíduos que possuem as mesmas características definidas por um determinado estudo.

A população do meu projeto será subdividida em 2 áreas. O primeiro grupo da população será constituído pelos moradores da cidade de Goiás e o segundo grupo será composto pelos turistas que se encontram na cidade no período abordado pela pesquisa.

O período da pesquisa será o Carnaval (21 e 22/02/04), a Semana Santa (09 e 10/04/04), um final de semana comum (15 e 16/05/04) e no Festival Internacional de Cinema e Vídeo Ambiental - FICA (05 e 06/06/04).

B - Amostra: É parte da população ou do universo, selecionado de acordo com uma regra ou plano.

Este projeto terá como base uma pesquisa de caráter exploratório onde se fará uma sondagem de tendências, ou seja, é uma espécie de pesquisa piloto que poderá dar suporte para uma futura pesquisa de mercado, portanto, a amostra em questão será a amostragem em pesquisa de mercado onde serão aplicados 30 questionários por cada período pesquisado, sendo 15 com os turistas e 15 com os moradores locais. Número este, escolhido aleatoriamente.

O projeto terá então um total de 60 questionários aplicados com turistas e 60 aplicados com a comunidade receptora durante todos esses períodos mencionados. 


\section{CAPÍTULO 2}

\section{REVISÃO DA LITERATURA}

O surgimento de uma nova conjuntura internacional, as mudanças culturais e o crescimento econômico de alguns setores do mundo situam o turismo num contexto, cuja importância não pode ser menosprezada, visto a sua influência econômica, política e cultural.

Conforme Beni (1997, p.125) “o mundo já penetrou no alvorecer de um novo tempo do turismo, uma era de viagens em escala maciça, verdadeiramente global onde as pessoas das mais variadas classes sociais e de todos os países viajam para todos os quadrantes do planeta”.

Estas mudanças ocorridas nas últimas décadas alteraram profundamente as condições de vida da população e reservaram um espaço privilegiado para o prazer, lazer e turismo.

O desenvolvimento da atividade turística vem de encontro com uma complexa rede de definições técnicas de turismo, até porque, a precisão científica é praticamente impossível, visto que, o turismo se expande e muda constantemente. Um exemplo de proposta pioneira desta área é a formulação teórica do economista austríaco Hermann van Schullard.

Schullard (apud Vaz, 1999, p.15) entendia que "o turismo é a soma das operações, principalmente de natureza econômica, que estão diretamente relacionadas com a entrada, permanência e deslocamento de estrangeiros para dentro e para fora de um país, cidade ou região”. 
Antes mesmo da consolidação do fenômeno turístico como atividade econômica propriamente dita, idéias individuais surgiram a respeito de sua conceituação.

O governador geral da Índia, Curzon (apud Beni, 1998, p.17) sugeria que “o turismo é uma escola em que o aluno nunca se gradua, é um templo onde o suplicante cultua, mas nunca vislumbra a imagem de sua veneração, é uma viagem com destino sempre à frente, mas jamais atingido onde haverá sempre discípulos, sempre contempladores, sempre errantes aventureiros”.

Não posso deixar de mencionar ainda, o fato de que, as definições podem surgir por meio de consenso entre um grupo, como é o caso da Conferência das Nações Unidas sobre Viagens Internacionais e Turismo, realizada em Roma em 1963, que estabeleceu as clássicas categorias de turista (permanência superior a 24 horas) e excursionista (permanência inferior a 24 horas).

Outra definição por consenso encontrada é da Organização Mundial de Turismo (OMT), que vê esta atividade como sendo "a soma de relações de serviços resultantes de um câmbio de residência temporária e voluntária motivado por razões alheias a negócios ou profissionais".

O que se pode verificar é que não existe certo ou errado nos inúmeros conceitos encontrados a respeito do Turismo, já que, todos se complementam.

Por mais complexa que seja, a atividade turística sem dúvida nenhuma, traz benefícios econômicos as populações, envolvem variáveis de caráter ecológico, tecnológico, social, demográfico, cultural, entre tantos outros. O turismo é acima de tudo, o deslocamento temporário de pessoas para fora de seu domicílio e envolvem um conjunto de equipamentos, bens e serviços de transporte, alojamento, alimentação, lazer e recreação.

Em razão de sua importância no contexto internacional, se faz necessário que cada vez mais definições sejam elaboradas, mais bibliografias da área sejam produzidas, publicadas e mais pesquisas sejam realizadas, a fim de aprimorar o conhecimento daqueles que trabalham na área e conseqüentemente melhorar a qualidade do serviço prestado. 
Vale inserir aqui o ecoturismo como sendo uma nova opção para viajar e passar as férias. Este tipo de turismo vem se destacando a cada dia no nosso país, pois o território brasileiro abriga boa parte das espécies de organismos viventes em nosso planeta. Esse patrimônio, único no mundo, deve ser conservado e não lacrado numa redoma de vidro.

É bom ressaltar, que o surgimento do ecoturismo deu-se a partir do momento que os seres humanos mudaram o seu modo de observar e se relacionar com o meio ambiente. Como meio ambiente Holder diz "entende-se a biosfera, isto é, as rochas, a água e o ar que envolve a terra, juntamente com os ecosistemas que ele mantém” (apud Ruschuman, 1997, p.19).

Segundo o filósofo John Locke (apud Wearing e Neil, 2001, p.16) “tudo na natureza é inútil até ser transformado em objetos de valor utilizáveis”. Isto significa dizer, que os ecossistemas sendo substituídos por ambientes construídos (habitações, indústrias, rodovias, cidades) só assim, satisfariam as necessidades humanas. Esse pensamento, mostra de fato, esse ímpeto pelo desenvolvimento, que acabou por ocasionar práticas sistemáticas de devastação, atingindo seu ápice no final dos anos de 1980, e durante a década de 1990. Foi somente depois de terem sido dados alguns alertas, que realmente a humanidade tomou consciência dos abusos cometidos contra a natureza, em nome do crescimento econômico.

"Na verdade, o ser humano sempre utilizou recursos naturais em seu benefício: água, madeira, frutas e outros alimentos extraídos das matas, minerais, e o próprio ar pareciam inesgotáveis e acessíveis a toda e qualquer pessoa. Os abusos, num problema de escala, começaram com a Revolução Industrial, no século XVIII, acentuando-se nos séculos XIX e XX, devendo-se considerar o aumento populacional como fator complicador” (Pellegrini, 1993, pág. 15).

Portanto, o esgotamento da natureza possibilitou maior interesse para com ela e para sua conservação, permitindo uma mudança no perfil da demanda que sentiu a necessidade do desenvolvimento sustentável.

"Por sustentável geralmente queremos dizer desenvolvimento que satisfaz nossas necessidades hoje, sem comprometer a capacidade das pessoas satisfazerem as suas no futuro. Tratase, portanto, de uma perspectiva em um prazo mais longo que o usual ao tomarmos decisões, $e$ envolve uma necessidade de intervenção e planejamento" (Swarbrooke, 2000, p.3). 
Cabe bem citar a idéia fundamentada de Murphy (apud Swarbrooke, 2000, p.6) que diz "nós não herdamos a terra de nossos antepassados, mas a tomamos emprestada de nossos filhos".

Já nas primeiras décadas de 1970, essa tomada de consciência a respeito da degradação do meio ambiente e esforço internacional em defesa da ecologia, foi o que levou a Organização das Nações Unidas (ONU) a convocar uma grande conferência de paísesmembros, com a colaboração de cientistas, no sentido de estudar esse fenômeno. Isso, no ano de 1972 na Suécia, que ficou então conhecida como Reunião de Estocolmo.

A Reunião de Estocolmo, hoje em dia, constitui um marco dos primeiros tempos da conscientização em âmbito mundial e dos problemas surgidos com a acentuada degradação do ambiente natural. Nas duas décadas que se seguiram a essa reunião, diversos outros encontros internacionais foram realizados, chegando-se a documentos importantes.

Conforme Pellegrini “no Brasil, na década de 1980/90, o debate de assuntos relacionados à ecologia provocou uma considerável conscientização dos problemas ambientais, com importante papel cumprido por órgãos de comunicação social, que chegam a reservar grandes espaços e tempos para notícias, entrevistas, mesas-redondas e semelhantes, além de matérias e programas importados. O assunto integrou também campanhas políticas de candidatos a cargos da administração pública, em todos os níveis” (1993, pág. 29).

Assim, o ecoturismo surgiu já nos anos de 1980, inicialmente, como uma alternativa à crescente ameaça imposta pelo turismo de massa, ou seja, é a introdução de um novo tipo de turismo, comedido, que tivesse mínimo impacto sobre ecossistemas naturais.

À medida que os impactos negativos do turismo foram sendo reconhecidos, uma série de iniciativas foi sendo tomada para administrar a atividade, empregando aí o conceito da sustentabilidade. Não posso deixar de mencionar que a mídia tem exercido um papel significativo nas pessoas quanto ao maior interesse pelo ecoturismo e/ou por segmentos ligados ao ambiente natural (turismo rural, turismo de aventura, turismo científico, entre outros). 
As preocupações com questões verdes fizeram com que surgisse então os diversos conceitos de ecoturismo, cada um expressado diferentemente, mas contendo sempre aspectos comuns entre si.

"Hector Ceballos - Lascurain é amplamente reconhecido como o primeiro a usar o termo ecoturismo. Em 1981, Ceballos Lascurain começou a usar o termo espanhol turismo ecológico para designar essa forma de turismo. Então em 1983, o termo se reduziu para ecoturismo, e ele o empregou em debates, quando era diretor geral do SEDUE - Ministério do Desenvolvimento Urbano e Ecologia do México”.(Wearing e Neil, 20001, p.5).

“A definição do termo como a conhecemos apareceu pela primeira vez em 1987, em um documento intitulado (O Futuro do Ecoturismo), que foi reproduzido no Mexico Journal” (Wearing e Neil, 20001, p.6) “.

Conforme Ruschmann (1997, p.21) "trata-se, portanto da renovação do turismo, cuja clientela busca a calma, as aventuras e o conhecimento mais profundo das regiões visitadas”.

Outra definição encontrada é da Sociedade Internacional de Ecoturismo, a maior e mais conhecida organização não-governamental, que definiu o ecoturismo como sendo “viagem responsável a áreas naturais, visando preservar o meio ambiente e promover o bem estar da população”.

Segundo Lindberg e Hawkings (2002, p.16) “o ecoturismo é mais do que uma pequena elite de amantes da natureza. É, na verdade, um amálgama de interesses que emergem de preocupações de ordens ambiental, econômica e social".

Independente qual definição seja correta, o ecoturismo é um segmento de mercado que se relaciona ao deslocamento responsável a áreas naturais, envolvendo as comunidades locais, com sua cultura e história. Deve estar relacionado a uma consciência ecologicamente correta, daí a importância de programas de educação ambiental destinados aos viajantes, ao poder público, a iniciativa privada e a comunidade.

Freqüentemente o ecoturismo se realiza em regiões remotas e protegidas, áreas de grande beleza, interesse ecológico e importância cultural. Hoje, essas áreas são criadas para 
conservar a biodiversidade e deter a perda em grande escala dos ecossistemas naturais. Em um país como o Brasil, com graves problemas sociais, o uso dessas áreas para fins turísticos é recomendável, pois pode gerar benefícios econômicos para a população da região.

“A primeira área natural protegida (Parque Nacional de Yellowstone) surgiu nos EUA, em fins do séc. XIX sendo considerado oficialmente a primeira Unidade de Conservação do mundo. Por outro lado, a área natural do atual Parque Nacional de Yosemite (EUA), foi decretada em 30 de junho de 1864, a primeira área de preservação do mundo".(Costa, p.11).

Já no Brasil, considera-se o Parque Nacional de Itatiaia, criado em 1937 no Rio de Janeiro como a primeira unidade de conservação do país, e depois deste, outros foram sendo criados ao longo dos anos.

De acordo com a União Internacional para Conservação da Natureza, (apud Costa, 2002, p. 12) “a unidade de conservação é uma superfície de terra ou mar consagrada à proteção e manutenção da diversidade biológica, assim como dos recursos naturais e dos recursos culturais associados, e manejada por meios jurídicos e outras eficazes”.

Vale citar aqui a criação da lei 9.985/2000 - Lei do Sistema Nacional de Unidades de Conservação (SNUC). As unidades de conservação integrantes do SNUC dividem-se em 2 grupos com características específicas (Unidades de Proteção Integral e Unidades de Uso Sustentável).

Portanto segundo a legislação ambiental brasileira "os parques pertencem ao grupo de unidades de conservação de proteção integral, e destina-se à preservação integral de áreas naturais com características de grande relevância sob o aspecto ecológico, beleza cênica, científica, cultural, educativa e recreativa, vedada às modificações ambientais e a interferência humana direta. Excetuam-se as medidas de recuperação de seus sistemas alterados e as ações de manejo necessárias para recuperar e preservar o equilibrio natural, a diversidade biológica e os processos naturais, conforme estabelecido em seu plano de manejo. Os Parques Nacionais (PARNA ou PN) comportam a visitação pública com fins recreativos e educacionais, regulamentada pelo plano de manejo da unidade. As pesquisas científicas, quando autorizadas pelo órgão responsável pela sua administração, estão sujeitas às condições e restrições determinadas por este, bem como ao que for definido em seu plano de manejo". 
Segundo Wearing e Neil (2001. p.63) "no mundo existem aproximadamente 8.500 áreas de proteção, que abrangem cerca de 5,17\% da superfície terrestre, observando que a criação de áreas de proteção aumentou muito durante os últimos anos”.

Constata-se então, que os parques, inicialmente criados por razões ligadas à recreação, hoje já mantêm também como foco, o lado preservacionista.

Cada vez mais, devido aos benefícios advindos da atividade ecoturística, os administradores de áreas protegidas estão procurando levar um número maior de visitantes a parques e reservas. As comunidades próximas a essas áreas protegidas estão podendo usufruir novas oportunidades.

Desta forma, a escolha do Parque Estadual da Serra Dourada, localizado na Cidade de Goiás é o meu campo de estudo a ser analisado, por acreditar que o ecoturismo em áreas de proteção possibilite fornecer resultados que demonstrem à sociedade, os benefícios da atividade como um todo. Vale ressaltar que o parque em questão representa uma unidade de proteção integral, cujo objetivo principal é preservar a natureza, sendo admitido apenas o uso indireto dos seus recursos naturais.

O sucesso da atividade irá depender da conquista e manutenção dos turistas, e para isso, é fundamental conhecê-lo, bem como, o mercado no qual está inserido. Justamente por isso será feita uma análise junto à demanda, a fim de verificar se os turistas que freqüentam a cidade teriam interesse e motivações de praticar o ecoturismo no parque. Além disso, será feito um estudo de percepção junto à comunidade receptora para saber se a mesma, mostra-se favorável quanto ao desenvolvimento de práticas ecoturísticas no Parque Estadual da Serra Dourada.

Por fim, caso a viabilidade seja comprovada, irei propor que o ecoturismo esteja intimamente ligado a história local, ou seja, ao processo de colonização do município. Para isso, irei sugerir que se elabore produtos ecoturísticos vinculados ao Programa "Caminhos do Ouro”, criado pelo SEBRAE/GO e AGETUR. 
Serão propostas organizadas e baseadas em experiências de sucesso, como é, por exemplo, o Circuito Turístico Estrada Real, que engloba os Estados de Minas Gerais, Rio de Janeiro e São Paulo. Este circuito representa o antigo caminho aberto pelas entradas e bandeiras no final do século XVII com a descoberta das reservas de ouro e diamantes, integrando uma série de atrativos em vários municípios destas regiões, revivendo a memória do Brasil e contribuindo ao mesmo tempo para a sustentabilidade do ecoturismo, pelo fato de envolver as comunidades locais.

Enfim, da mesma forma que existe o Circuito Turístico da Estrada Real, acredito que o Parque Estadual da Serra Dourada também possa ser formatado em um produto, o qual envolva toda essa questão histórica referente à época da colonização dos bandeirantes paulistas, vindo até mesmo, a ser um diferencial competitivo no mercado, já que, na região do parque existem áreas de antigos garimpos, bem como, uma antiga estrada por onde passaram os colonizadores. É uma área rica em histórica, e claro, de grande beleza paisagística. 


\section{CAPÍTULO 3}

\section{CIDADE DE GOIÁS}

\section{1 - Contextualização Histórica e Geográfica do Município}

Este capítulo faz um relato histórico-geográfico da Cidade de Goiás, uma vez que, o Parque Estadual da Serra Dourada, objeto de pesquisa dessa monografia, está localizado em partes do território desse município. Por isso, entendo que essa é uma maneira de estar conhecendo um pouco mais a localização dessa unidade de conservação, bem como, o contexto em que se encontra inserido. Desse modo, o capítulo retrata também a importância da manutenção do patrimônio histórico da cidade, a necessidade de se buscar o fortalecimento da identidade local e a própria atividade turística presente nesse município.

Assim, historicamente, o Brasil constituiu-se, no período colonial, em colônia de exploração, cuja organização da produção utilizou-se da adoção do regime do trabalho escravo. Como é sabido, durante o período colonial a economia brasileira caracterizou-se por ciclos econômicos, sendo primeiro o do pau-brasil, seguindo-se do açúcar e depois do ouro. A base política fundamentou-se na centralização administrativa, primeiro com as Capitanias Hereditárias e depois com a implantação do Governo Geral, consolidando o Pacto Colonial (pacto entre a Metrópole - Portugal, e suas Colônias, dentre elas o Brasil, em que ambas as partes davam e recebiam numa troca de benefícios para todos). 
"Durante os séculos XVI e XVII, as regiões interioranas do país permaneceram praticamente esquecidas, devido ao sistema de colonização implantado no país, que teve por base o latifúndio monocultor açucareiro e exportador, cuja produção veio concentrar-se na faixa litorânea, uma vez que esta oferecia facilidades tanto de solo como de clima e, sobretudo, de transporte" (Souza e Carneiro, 1996, p.14).

Portanto, o século XVI foi à época em que os colonizadores mantiveram contato com apenas a fachada de Mata Atlântica do país. Segundo o geógrafo Aziz Ab’Saber (2002, p.30) “durante muito tempo as condições paisagísticas do país foram tachadas de monótonas e extensivas. Observadores estrangeiros que visitavam o Brasil na primeira metade deste século não tiveram a sensibilidade suficiente para perceber as sutis variações nos padrões de paisagens e ecossistemas de nosso território. Isso provocou um certo retrocesso em relação aos conhecimentos acumulados no decorrer do século XIX, mormente no que concerne às contribuições pioneiras dos viajantes naturalistas”.

As feições hoje da Cidade de Goiás, podem ser comparadas com as características originais da cidade, graças às descrições e desenhos deixados justamente por esses observadores estrangeiros que visitaram a região nas primeiras décadas do século XVIII, ou seja, pode-se verificar a espantosa permanência dos modelos da cidade antiga ao longo dos últimos anos.

É dentro desse contexto de penetração no interior do Brasil Central, que se destaca então a importância da presença dos viajantes naturalistas. Alguns dos naturalistas europeus mais renomados do século XIX organizaram expedições científicas a este verdadeiro território até então desconhecido.

A historiografia brasileira, hoje tem como uma de suas principais fontes a literatura de viagens do século XIX, em que esses viajantes, visitaram em especial Goiás, deixando preciosas descrições da cidade e de sua região. O famoso viajante francês Auguste de SaintHilaire, por exemplo, realizou viagem ao Brasil entre 1816 e 1822, visitando as províncias do Centro e do Centro-Sul do país, entre elas, a província de Goiás, e recolheu pelo caminho um proveitoso acervo botânico, registrando cada passo de suas andanças em um diário de viagem. 
Saint-Hilaire escreveu vários livros resultantes de suas pesquisas e viagens, sendo esses relatos sempre enriquecidos com lições de história, geografia, sociologia e antropologia. Algumas pessoas chegam a considerá-lo um pioneiro do turismo ecológico, já que, a caminho de Goiás, segundo seus documentos, ele desviou-se do roteiro só para ver uma cachoeira, a Casca D’Anta, primeira grande queda do Rio São Francisco na Serra da Canastra (MG), fazendo a seguinte descrição: “... para se ter uma idéia de como é fascinante a paisagem ali, o leitor deve imaginar em conjunto tudo o que a natureza tem de mais encantador: um céu de um azul puríssimo, montanhas coroadas de rochas, uma cachoeira majestosa, águas de uma limpidez sem par, o verde cintilante das folhagens e, finalmente, as matas virgens que exibem todos os tipos de vegetação tropical”.

Além de Saint-Hilaire, o austríaco Johann Emmanuel Pohl percorreu esse território entre 1817 a 1821 e em 1828, foi a vez do inglês William John Burchell.

Pode-se dizer que o Brasil permaneceu durante quase todo o século XVI, como uma terra vasta, encoberta por imensas florestas, onde viviam várias nações indígenas. A presença do homem branco só se fazia notar ao longo de sua costa. Era só. Em seu interior, somente aventureiros de espírito mais arrojado ousavam entrar.

"Entre os aventureiros que ousaram arriscar os primeiros passos nessas antigas trilhas estavam missionários jesuítas procedentes de Portugal e instalados em São Vicente, na baixada Santista. Escalaram as encostas da Serra do Mar e avançaram algumas léguas, encontrando o planalto de Piratininga, onde acamparam. No dia 25 de janeiro de 1554 foi celebrada a primeira missa nesse local. Desde então, começou a se formar ali uma povoação que, com o tempo se transformou na cidade de São Paulo” (Leão, 1999, p.9).

"A descoberta e colonização da savana brasileira (cerrado), iniciou-se então em fins do século XVI, com colonizadores franceses anteriores a 1616 e, depois com padres jesuítas, ao norte, no Rio Tocantins, e ainda com os famosos bandeirantes de São Paulo, pelo sul. As bandeiras compostas de paulistas e índios civilizados, logo miscigenados entre si, avançaram sobre os territórios espanhóis a oeste, capturando outros índios e, ao cabo de um século, encontraram jazidas de ouro, nas altas montanhas de Minas Gerais. Em seguida, invadindo o cerrado, fundaram no Centro-Oeste do Brasil as regiões auríferas de Cuiabá, Vila Bela, no Mato Grosso, Vila Boa de Goiás que nucleava diversas outras áreas de mineração" (Bertran, 1994). 
Portanto, no século XVII, estabeleceu-se uma linha de penetração constante devido ao bandeirismo e à catequese Jesuíta. Especificamente referindo-se à conquista do território de Goiás, esta foi efetuada então, por meio de duas vias de penetração: Segundo Doles “uma oriunda do Norte, que, pela via fluvial do Tocantins, penetrou a porção setentrional de Goiás e outra paulista, advinda principalmente do Centro-Sul” (apud Sousa e Carneiro, 1996, p.14).

É certo que, já no primeiro século de colonização do Brasil, diversas expedições, “entradas”, “descidas”, “bandeiras”, percorreram parte do território do atual Estado de Goiás, embora não se conservem notícias precisas. Estas expedições eram umas de caráter oficial destinadas a explorar o interior e buscar riquezas minerais, e outras, empresas comerciais de particulares, organizadas para a captura de índios. Inicialmente as bandeiras saídas de São Paulo eram feitas em canoas. Mais tarde, depois de 1630 introduziu-se o uso de muares (animal pertencente à raça do mulo) e as bandeiras preferiam a viagem por terra.

"O interesse então pela mineração aparece nas últimas décadas do século XVII, mas, em meados do século $X V I$, há registros de bandeiras de apresamento de índios, destacando a de Sebastião Marinho, em 1592. Ao todo, há registros de 14 bandeiras, sendo que uma das últimas foi a de Sebastião Paes de Barros, em 1673. Tudo indica que a bandeira de Bartolomeu Bueno da Silva (pai) tenha feito parte dessa expedição” (Souza e Carneiro, 1996, p.23).

É bom ressaltar que as primeiras bandeiras não vinham para fixar-se em Goiás, tendo a intenção apenas da captura de índios, por isso, costuma-se dizer que o descobridor de Goiás foi Anhanguera (filho). Isto não significa dizer que ele fosse o primeiro a chegar a Goiás, mas sim que ele foi o primeiro com a intenção de se criar povoações nessa região.

Assim, as origens históricas de Goiás estão intimamente ligadas à corrida do ouro empreendida pelos bandeirantes paulistas. Entre 1682 e 1684, uma expedição chefiada por Bartolomeu Bueno da Silva (pai) atravessa um imenso território, à época conhecido como Sertão dos Goyases. Bartolomeu Bueno da Silva, que do contato com os índios Goyases recebeu a alcunha de Anhanguera, (que na língua dos nativos significava diabo velho), segundo relatos da história, era ignorante, valente, astuto e de caráter perseverante.

Segundo relata Pohl em seu livro Viagem ao Interior do Brasil “uma prova da rara presença de espírito de Bartolomeu Bueno ficou demonstrada por ele, certa vez quando, ante o perigo 
iminente, salvou-se das mãos dos índios com a ameaça de que, se não satisfizessem as suas exigências, incendiaria os rios. Depois da ameaça pôs fogo numa tigela com aguardente, o que deixou os índios aterrorizados, fazendo com que consentissem em obedece-lo".

Portanto, o processo de ocupação do Estado de Goiás deu-se dentro da conjuntura do descobrimento do ouro no Brasil. Em 1690 descobriram-se as minas de ouro em Minas Gerais, foi então que Anhanguera (filho), paulista que tinha vivido em Minas Gerais, com mais dois outros paulistas (João Leite da Silva Ortiz e Domingos Rodrigues do Prado) pediu licença ao rei para organizar uma bandeira que viesse para Goiás. "A resposta do rei chegou no ano seguinte, delegando a Dom Rodrigues César Menezes a assinatura do contrato com esses três bandeirantes. O rei concedeu, entre outros benefícios, o cargo de superintendente das minas a Bartolomeu Bueno da Silva, de guarda-mor a João Leite da Silva Ortiz e de escrivão a Antônio Ferraz de Araújo” (Assunção. Goiás nos 500 Anos do Brasil. Jornal O Popular. Goiânia, 16/04/2000).

O regimento da bandeira de Bartolomeu Bueno da Silva (filho), tinha a atribuição de descobrir minas de metais preciosos, estabelecer um sistema de autoridade e paz com os índios e principalmente cobrar os direitos reais, como, por exemplo, o quinto, que era a quinta parte que se retirava do ouro a ser entregue para o rei, sendo somente o restante devolvido ao proprietário. Assim, em 1722 partiu a bandeira de Bartolomeu Bueno da Silva (filho), cuja viagem durou cerca de três anos. Somente durante sua segunda viagem, em 1727 inicia-se o processo de povoamento do atual Estado de Goiás.

Esses primeiros tempos são marcados então, por aventureirismo aonde vão se abrindo caminhos e aonde vão se rechaçando índios. Deste modo, os desbravadores povoam uma imensa área aonde a atividade mineratória iria futuramente absorver todos os braços livres ou escravos.

“Exploradas inicialmente as lavras da Barra (Buenolândia, hoje), em 1727 Bartolomeu Bueno (filho) descobria as ricas aluviões do Rio Vermelho, entre a Barra do Manuel Gomes e do Bagagem, local para onde se transferiu com toda a sua parentela e agregados, fazendo logo erigir uma capela sob a invocação de Nossa Senhora Santana, a milagrosa padroeira de seu berço paulista” (Élis, 1979, p.6). 
Portanto, foi desta forma que surgiu a atual Cidade de Goiás, antiga capital do Estado, fundada em 1727, nos contrafortes ocidentais da Serra Dourada, por Bartolomeu Bueno da Silva, o filho, que como dito anteriormente, por ali já havia estado quarenta anos antes, nas cercanias da atual Cidade de Goiás, acompanhando seu pai, de mesmo nome e alcunha Anhanguera.

Surgiu como um pequeno arraial às margens do Rio Vermelho (afluente do rio Araguaia e cujo nome foi dado em razão de suas águas ficarem sujas com os trabalhos de mineração). A cidade, situada a quase $500 \mathrm{~m}$ de altitude, que inicialmente foi chamada de Arraial de Sant`Ana, surgiu como sendo então resultado do processo de expedições exploratórias dos bandeirantes vindos de São Paulo, desrespeitando os limites da Linha de Tordesilhas, que marcava os limites entre os territórios portugueses e espanhóis na América do Sul. Segundo dados da Unesco (2002, p.232) “assim, acabaram por incorporar ao território brasileiro mais de três milhões de quilômetros quadrados de terras oficialmente pertencentes aos espanhóis”.

Assim, a primeira lavra aurífera de Goiás foi descoberta na cabeceira do Rio Vermelho, local onde se fundou o Arraial de Sant’Ana. Além do Rio Vermelho, como já mencionado, a maior concentração aurífera em Goiás deu-se em torno das serras dos Pirineus (Pirenópolis) e Serra Dourada (Cidade de Goiás). Os primeiros arraiais no Estado se caracterizaram pela irregularidade e falta de planejamento. Segundo Souza e Carneiro (1996, p.16) “formaram-se três zonas de povoamento assim divididas: $1^{a}$ zona (Centro Sul), englobando Arraiais de Santa Cruz, Santa Luzia (Luziânia), Meia Ponte (Pirenópolis), Jaraguá, Villa Boa (Goiás), Cocal e Barra; $2^{a}$ zona (Região do Tocantins no limite com Maranhão), englobando os Arraiais de Traíras, Água Quente, São José (Niquelândia), Santa Rita, Muquém e Cachoeira e finalmente a $3^{a}$ zona (Limite com a Bahia) englobando os Arraiais de São Félix, Cavalcante, Natividade e Porto Real (Porto Nacional)".

Os reflexos da Serra Dourada materializavam-se no precioso metal que o leito do Rio Vermelho generosamente deixava nas bateias aventureiras. Rapidamente surgiram também outros arraiais: o da Barra, Ouro Fino, Ferreiro. Foi, porém, o de Sant`Ana que o governador de São Paulo, Dom Luís de Mascarenhas, Conde d’Alva, escolheu, em 1739, como sede da comarca instituída para melhor controle das minas. 
Isto quer dizer, que com a divulgação da notícia dos novos achados (ouro) milhares de pessoas foram para essa região. Da noite para o dia um arraial surgia, reunia milhares de pessoas e imediatamente desaparecia, conforme o ouro surgisse e se esgotasse.

“O Arraial de Sant’Ana crescia em população e estabilidade, o que levou as autoridades portuguesas a enviar a Goiás o conde de Sarzedas, capitão-general de São Paulo, com o objetivo de se criar a primeira vila. A missão frustrou-se pela morte de Sarzedas em viagem. O substituto dele, Dom Luís de Mascarenhas, dois meses após assumir o governo de São Paulo, vem a Goiás para dar cumprimento à missão de Sarzedas” (Élis, 1979, p.6).

Dessa forma, Lisboa queria que se criasse no distrito das minas de Goiás, uma Vila e sua Comarca, que era a divisão judiciária administrativa sob a autoridade de um ouvidor. O objetivo era administrar a justiça, instalar uma força militar, organizar o recolhimento de impostos, enfim, implantar a autoridade do Estado português.

O vilarejo de exploradores de ouro transformou-se, então, em vila administrativa no ano de 1739 e recebeu o nome de Villa Boa de Goyaz, em homenagem a Bartolomeu Bueno e ao mesmo tempo aos índios Goyazes, seus primeiros habitantes. Na época, tomaram-se providências para a criação dos primeiros prédios públicos para estabelecer condições de abrigar a administração local. Assim, foram edificados, por exemplo, a Igreja de Nossa Senhora da Boa Morte, o Largo do Chafariz, a rua da Fundição, o Largo do Rosário e o Palácio Conde dos Arcos, este construído entre 1735 e 1759, entre outros.

De acordo com Élis (1979, p.7) “praticamente a sede da Capitania de São Paulo passou a ser Villa Boa, pois em Goiás viveu Dom Luís de Mascarenhas (governador de São Paulo) os três primeiros anos de sua administração”.

Villa Boa apresentava um comércio bastante movimentado nesta época e segundo estatísticas de 1741, dão para o território goiano 253 estabelecimentos comerciais, dos quais 146 eram vendas. Calcula-se que um terço desses estabelecimentos estivesse em Villa Boa. Além disso, a população começou a crescer e segundo o historiador Palacín, nesta época, havia a proporção de três escravos para cada homem branco. 
“Nunca tanto ouro foi visto nas minas de Goiás, como no tempo de D. Luís de Mascarenhas. Atingia o apogeu, a faina mineradora quando a 20 de setembro de 1740 morria o descobridor de tais tesouros, o cabo Bartolomeu Bueno da Silva” (apud Élis, 1979, p.8).

Conforme Palacín “Os paulistas foram os descobridores das minas de Goiás. Esse fato fez com que a província pertencesse a São Paulo até 1749. Toda Capitania do Brasil tinha um governo próprio e independente, ligado diretamente ao Rei e aos organismos centrais de Lisboa, especialmente ao Conselho Ultramarino" (apud Souza e Carneiro, 1996, p.27).

A Província de Goiás neste período já rivalizava com São Paulo, chegando a superá-la em diversos aspectos, inclusive na população. Por isso, foi então separado Goiás do governo de São Paulo.

Portanto, em 1748, a Capitania de São Paulo foi desmembrada em mais duas: Mato Grosso e Goiás. O primeiro governador da recém-criada Capitania de Goiás, Dom Marcos de Noronha, Conde dos Arcos (1749-1755), transformou a vila em pequena capital, sendo então, elevada à sede da Capitania Geral em 8 de novembro de 1749. Nesta época, Goiás compreendia áreas do atual Distrito Federal, do Tocantins, as regiões do rio da Morte e Pardo nos Estados de Mato Grosso e Mato Grosso do Sul, o triângulo mineiro, em Minas Gerais, e Carolina, hoje no Estado do Maranhão.

Goiás desempenhou um papel estratégico importante como centro de colonização da savana brasileira, cumprindo, durante mais de dois séculos, algumas das funções hoje exercidas por Brasília.

A Villa tornou-se cidade em 17 de setembro de 1818 através da Carta Régia de Dom João VI, com o nome de Cidade de Goiás, mas a publicação no Correio Oficial só aconteceu exatamente um século depois, em 17/09/1918. Conde dos Arcos construiu a Casa de Fundição, o Palácio e o Quartel. Seu sucessor ergueu a Casa de Câmara e Cadeia, em 1761.

A alteração do nome de Villa Boa de Goyaz para Cidade de Goiás só ocorreria então acompanhada de melhorias urbanas significativas, como a criação do Hospital, da Biblioteca Pública e do Liceu (escola). 
O governador José de Almeida, Barão de Mossâmedes (1772-1777), restaurou estradas e pontes, construiu a Fonte da Carioca, o Chafariz de Cauda e o Teatro. José de Almeida era considerado um homem possuidor de uma sólida cultura intelectual, além disso, foi popular, pois demonstrou experiência na arte de governar e pediu a nomeação de professores públicos.

Neste período, pode-se dizer que Villa Boa atingira sua plenitude, em que os principais logradouros foram estabelecidos, calçados e melhorados, e os edifícios públicos mais significativos construídos. É justamente nesta época, que acontece o progressivo esgotamento das aluviões, assim, sua população diminuiu consideravelmente, bem como, a própria pobreza impedia que novas construções com as dimensões das demais fossem erguidas.

Entretanto, é a Luís da Cunha Meneses (1778-1783) que se deve creditar a estruturação da cidade que conhecemos hoje, pois foi o responsável pela elaboração, em 1782, do prospecto de Villa Boa de Goyaz para reordenar o processo de ocupação urbana. Além disso, arborizou a cidade, alinhou suas ruas e organizou a bela Praça do Chafariz. Vale ressaltar, que foi já dentro desse espírito de decadência aparente que Luís da Cunha Menezes assumiu o Governo de Goiás.

A província de Goiás foi a segunda região maior produtora de ouro no país, mas sua produção não foi uniforme devido às precárias técnicas empregadas para a retirada do ouro de aluvião, desta forma, a partir de 1770, os resultados da exploração do ouro decaem fortemente. Inicia, então, um longo período de estagnação para Goiás.

A partir desta época as descobertas de ouro começam a diminuir no atual Estado de Goiás, mesmo assim, alguns sucessivos governadores continuaram investindo na procura de novas jazidas, e quase todo o território de Goiás foi vasculhado. Entretanto, somente no ano de 1778, a decadência do ouro começa a ser sentida mais intensamente. Com a quantidade de ouro se esgotando foi ficando cada vez mais difícil a vida de muitos garimpeiros, por isso, um grande contingente de pessoas acabou abandonando a Capitania de Goiás, ficando esta isolada do resto do país.

Segundo Tiballi “a decadência da mineração em Goiás se deu devido a um conjunto de fatores tais como as técnicas rudimentares (bateia), a carência de mão-de-obra, a má administração 
local, os interesses escusos do governo central e esgotamento das minas de superfície, suficientes para não permitir que Goiás estruturasse sua economia através da mineração aurífera” (apud Souza e Carneiro, 1996, p.29).

Nessa época, segundo relata Saint-Hilaire, em seu livro, Viagens às nascentes do Rio São Francisco “essa província não tem, por assim dizer, nenhum comércio, suas exportações são insignificantes, e em vários pontos dela é praticamente impossível vender alguma coisa”.

Apesar da decadência da mineração, por outro lado, pode-se dizer que a corrida do ouro abriu caminhos para Goiás, ou seja, a economia de subsistência não mais comportava o escravo, pois seu custo era alto. Esse período de crise na economia e na sociedade goiana provocou mudanças como, por exemplo, a proliferação de uma economia agropecuária e conseqüentemente mudanças nas relações de trabalho, onde o escravismo cedeu lugar ao trabalho familiar, isto porque, o comércio já se ressentia da decadência da mineração.

A pecuária, portanto, seria a possível saída para a crise, mas o isolamento geográfico da capitania (Cidade de Goiás), era um obstáculo a ser transposto. Tal atividade acabou sendo responsável pelo surgimento de novos centros urbanos no sudoeste do Estado como Rio Verde, Jataí, Caiapônia, Quirinópolis, entre outros.

O declínio da mineração se deu de forma gradativa durante todo o século XVIII, levando o Brasil a uma grave crise econômica. Segundo Souza e Carneiro (1996, p.31) “ $a$ crise do sistema colonial se inicia com o surgimento do capitalismo industrial e com a disputa entre França e Inglaterra pela ampliação de mercados, resultando no Bloqueio Continental, em 1806. Portugal, sempre foi aliado da Inglaterra e, sob ameaça da invasão do país por Napoleão Bonaparte, aceita a Proteção Inglesa, imigrando a Família Real para o Brasil”.

A vinda da Família Real para o Brasil inicia a quebra do sistema colonial e propicia a Independência do país. Deste modo, o Príncipe Regente D. Pedro, proclama a independência em 7 de setembro de 1822, iniciando assim, o período imperial brasileiro, que teve curta duração. “A abdicação de D. Pedro I, em 1831, que opta pelo trono português e deixa aqui seu filho mentor, Pedro de Alcântara, leva o Brasil ao período regencial que durou de 1831 a 1840" (Souza e Carneiro, 1996, p.37). 
Foi durante o Império que justamente a cidade assistiu à ascensão das artes em geral e do nível cultural da elite, o que favoreceu o desenvolvimento das delicadas obras de Veiga Valle, além do surgimento de poetas, músicos, compositores de valor e uma cultura literária que fez da cidade o berço das tradições e costumes de inúmeros goianos atuais.

Consolidada a Independência, agrava-se a crise econômica, por isso, o período regencial, segundo dados históricos, foi sacudido por constantes revoluções populares de norte a sul do país. Foi nesse período, que surge um movimento separatista no norte de Goiás, em 1821, onde os grandes proprietários de terras afirmavam que apesar de pagar impostos, os benefícios do governo não chegavam até lá, além disso, afirmavam que o povo vivia em completa miséria. D. Pedro I não reconheceu o direito dos revoltosos, mas o ideal de libertação no norte continuou vivo e tornou-se realidade com a criação do Estado de Tocantins em 1988.

O descaso do governo com os goianos levaram, após a abdicação de D. Pedro I, ao movimento revolucionário que depôs o presidente da Província e demitiu todos os portugueses dos cargos administrativos. Assim, a rebelião levou a nomeação de presidentes goianos, e a agropecuária, passou a ser a principal atividade econômica de Goiás.

Posteriormente, instituiu-se a proclamação da maioridade de D. Pedro II, o que foi a solução encontrada para acabar com essa crise de autoridade reinante no país e centralizar o poder novamente. Essa centralização se fez sentir em Goiás, e, os novos presidentes da Província que voltaram a ser nomeados eram estrangeiros, deixando somente o cargo de vicepresidente para o clã dos goianos.

O desenvolvimento da agropecuária em Goiás no século XIX possibilitou a organização e o crescimento das vilas, onde o fazendeiro era o representante do poder econômico e político, consolidando as bases do coronelismo. Mesmo assim, devido à precariedade dos meios de comunicação e transporte, o isolamento da Província ainda se fazia sentir. Começam a emergir nesse período a elite das famílias goianas na busca pelo poder local.

Com a abolição da escravidão no ano de 1888 e mesmo com a Proclamação da República em 1889, os anseios de liberdade e justiça social em Goiás não se concretizou, 
justamente porque, as famílias importantes locais, formaram as oligarquias e os coronéis, com seus capangas, constituiram-se no poder econômico e político local. As oligarquias se sucederam no poder desde o advento da República, com a família dos Bulhões, dos Xavier de Almeida e dos Caiado, até 1930.

Vale destacar aqui que foi justamente depois do advento da República, em 1889, que o Congresso Nacional introduziu na Constituição de 1891 a velha idéia de se instalar a capital no coração do Brasil. Uma expedição de cientistas, dirigida pelo astrônomo belga Louis Cruls, foi enviada ao planalto central para delimitar o território da futura capital do país.

Assim, nas últimas décadas do século XIX, grupos locais manifestaram insatisfação com a administração e responsabilizaram os presidentes estrangeiros pelo grande atraso de Goiás, passando a lutar pelo nascimento de uma consciência política, com a criação do partido político liberal (1878) e conservador (1882). A transformação então, do regime monárquico em republicano ocorreu sem grandes dificuldades, e os Bulhões (partido liberal) tornaram-se os donos do poder até o ano de 1909. Em seguida, surge a chamada oligarquia Caiado, que perdura até os anos de 1927.

Nesse mesmo período, a partir de 1922, jovens oficiais começaram a protestar contra essa situação oligárquica. Com o fracasso de uma revolta, um grupo deles empreendeu, de 1924 a 1926, uma marcha famosa através do cerrado brasileiro, aproximando-se da Cidade de Goiás, mas evitando sempre os combates diretos. Essa marcha, ficou conhecida pelo nome de Coluna Prestes e revelou um Brasil esquecido.

É nesta época, que acontece a crise do sistema capitalista em amplitude mundial (Quebra da Bolsa de Valores de Nova Iorque em 1929), que repercute também no Brasil, principalmente no setor agrário, e acaba promovendo a quebra do setor cafeeiro. Segundo Souza e Carneiro (1996, p.65) "a revolução de 1930, foi a solução encontrada por facções insatisfeitas da própria classe dominante que, por meio do Estado, tentam impor a unidade nacional, utilizando-se das instituições, contra o particularismo regional (coronelismo). O populismo foi então, a forma política adotada”.

"Foi exatamente em 1930 (ano de eleições para presidente), que o paulista Washington Luiz, então presidente, apoiou Júlio Prestes (outro paulista) para ser candidato, embora o acordo com 
Minas Gerais dizia que naquele ano o chefe da nação teria que ser mineiro. Os políticos de Minas Gerais, vendo seus direitos contrariados se uniram aos políticos da Paraíba e do Rio Grande do Sul, juntos indicando outro candidato a presidente (o gaúcho Getúlio Vargas) e vice o paraibano João Pessoa. Acabou vencendo Júlio Prestes, mas João Pessoa foi assassinado na Paraíba por problemas políticos locais, e isso bastou para que estes Estados não aceitassem o resultado das eleições, derrubando assim, Washington Luiz e colocando no poder Getúlio Vargas. Tal movimento foi denominado Revolução de 30" (autor desconhecido, 1997).

Portanto, a revolução de 1930 leva à formação de um governo provisório, com a criação de uma Junta Militar cujo principal objetivo era diminuir o poder local dos coronéis e conseqüentemente fortalecer o Estado Nacional. Foi a revolução de 1930 que marcou o poder de Pedro Ludovico Teixeira, abrindo uma nova fase na história do Estado de Goiás.

Pedro Ludovico Teixeira, cuja liderança se impôs durante todo o tempo em que Getúlio foi presidente (15 anos), fazia parte do núcleo de oposição que se esboçava nos municípios de Rio Verde, Inhumas e Anápolis. Com a vitória da Revolução de 1930, foi imposto a Goiás um governo provisório, composto por membros, dos quais Pedro Ludovico fazia parte, sendo este, posteriormente, nomeado interventor (governador não eleito).

Enquanto interventor, Pedro Ludovico, buscou criar condições para impulsionar a ocupação do Estado, isto é, para a expansão do capitalismo. A estratégia utilizada foi direcionar os excedentes populacionais para os espaços demográficos vazios, na tentativa de aumentar a produção econômica. Desta forma, a resolução do Estado, respaldado na ideologia desenvolvimentista e nacionalista, bem como, os jovens políticos que assumiram o poder constatando a incapacidade física, moral e política de exerce-lo a partir da Cidade de Goiás, levou à resolução da mudança da capital de Goiás para Goiânia, em 1933.

A situação geográfica de Villa Boa, entre serras de difícil acesso, a insalubridade do clima e a falta de estradas para uma melhor comunicação com o centro-sul constituíram as causas principais necessárias para a construção de uma nova capital.

A resistência à mudança da Capital, se fez sentir até recentemente pelos moradores de Goiás, até porque, os grandes fazendeiros, mais conhecidos como coronéis, eram muito poderosos e a permanência da sede do governo em sua região era muito importante para a 
manutenção dos seus poderes. Entretanto, a pedra fundamental foi lançada em 24 de outubro de 1933, a mudança provisória aconteceu em 7 de novembro de 1935 e em 1937 deu-se a mudança definitiva para Campinas (atual cidade de Goiânia), dando início a uma outra parte da história do Estado de Goiás.

Com a criação de Goiânia confirmando a viabilidade de se construir uma capital inteiramente nova no centro quase despovoado do Brasil, o presidente Juscelino Kubitschek decidiu transferir a capital federal para essa área em 1960, quando Brasília foi então inaugurada e a expansão interna do Brasil, iniciada com Goiás, chegava ao seu apogeu.

Assim, hoje a Cidade de Goiás, há aproximadamente 149 km de Goiânia e 320 km de Brasília, apesar de não mais ser a capital do Estado, é importante não especificamente no quesito político, mas no que se refere a sua grande potencialidade para o turismo, bem como, para o ecoturismo.

A cidade assenta-se sobre uma área de transição geológica mais acidentada do que os chapadões e campos gerais do Brasil Central. O município caracteriza-se por apresentar uma importante interação com o cerrado, que constitui o segundo maior ecossistema da América Latina, ocupando 25\% do território brasileiro. Árvores como o ipê-amarelo e as palmeiras, como macaúba e buriti, podem ser vistos nas veredas e brejos existentes na região. Também se encontram plantas medicinais como a arnica, a sucupira e a douradinha.

A Cidade de Goiás situa-se, em um cenário topográfico singularmente bonito, dentro de um vale envolvido por morros verdes e ao sopé da Serra Dourada. Está localizada, dentro da microbacia do Rio Vermelho, com terreno bastante acidentado onde se destacam, além da Serra Dourada, os morros do Cantagalo e das Lages.

Com cerca de 500 metros de altitude, de clima úmido e aproximadamente 340.166 km², o município conta com uma vegetação bastante variada, dividida em regiões de florestas, cerrados e campos, sustentando uma boa atividade pecuária e agrícola, além da exploração do ouro, esmeralda, calcário, e reservas de prata, cobre, barinita, gnaisse, talco, cromita, fosfato, manganês e zinco. Além do Rio Vermelho, o município também é cortado pelos rios Urú, do Peixe, Ferreira e Índio. 
A colonização portuguesa permitiu que a flexibilização dos traçados urbanos da Cidade de Goiás configurasse numa série de arranjos espaciais, na implantação de sua malha urbana, integrando-se à paisagem nativa, motivando um tipo particular de relação homem e meio ambiente Assim, a cidade que pousa sobre o vale da Serra Dourada e se molda às curvas sinuosas do Rio Vermelho, é, portanto, uma área ideal para a prática do ecoturismo, em decorrência de sua beleza e localização geográfica, bem como, pela história que ali está impregnada.

\section{2 - O Município Preservando Sua Memória e Fortalecendo Sua Identidade Local}

Hoje em dia, devido à expansão em grande escala do turismo em todas as partes do mundo, ganham força, os questionamentos a respeito das conseqüências que essa atividade ocasiona para o meio ambiente natural e cultural.

De acordo com Barretto "biólogos e ecologistas, principalmente, têm-se preocupado com os impactos do turismo na natureza; sociólogos e antropólogos têm-se preocupado com os impactos nas populações receptoras, ao passo que historiadores e arquitetos têm prestado a atenção nas áreas da cultura material, verificando os efeitos do turismo em bens culturais, tais como o patrimônio histórico" (2000, p. 7).

Primeiramente é bom ressaltar, que as primeiras preocupações e debates a respeito de conservação/restauração/intervenção/reconstrução/revitalização de imóveis, com valor extraordinário, começaram em fins do século XIX, com especialistas e autoridades do Velho Continente. No Brasil, por outro lado, são raras as manifestações e iniciativas de preservação de bens patrimoniais nesses tempos passados, mas mesmo assim, comparando-se as atenções face ao patrimônio cultural e ao patrimônio natural, o patrimônio cultural recebeu cuidados especiais antes mesmo, dessas questões relativas ao meio ambiente.

Esses cuidados referentes ao patrimônio cultural, vêm desde os anos 30, mediante a criação do Serviço do Patrimônio Histórico e Artístico Nacional (SPHAN) pela lei federal 378, mais especificamente no ano de 1937. Apesar de não dispor de verbas e de elemento humano especializado, o SPHAN conseguiu preservar muitos bens culturais. Enquanto isso, nem no Brasil nem em outros países, como dito no parágrafo anterior, havia grande 
preocupação por ecologia, de modo que, a preservação do meio ambiente só se fez sentir nos anos de 1970, refletindo iniciativas dos países do Primeiro Mundo e reuniões especiais da Organização das Nações Unidas para Educação, Ciência e Cultura (UNESCO).

Assim, a década de 1930, é quando se dá o grande passo no sentido de preservação sistemática do patrimônio nacional, quando Mário de Andrade ficou então encarregado de elaborar anteprojeto de lei visando à preservação. Já no ano de1972, em Paris, a UNESCO cria um tratado internacional denominado "Convenção sobre a Proteção do Patrimônio Mundial Cultural e Natural”, para incentivar a preservação de bens culturais e naturais considerados significativo para a humanidade, vindo então a definir e especificar o Patrimônio Cultural em nível internacional. Em nosso país, a Convenção de 1972 só foi aprovada em 1977.

No Brasil, a questão do patrimônio no que se refere a prédios, está sendo gerida por órgãos oficiais como o Instituto do Patrimônio Histórico e Artístico Nacional (IPHAN), o Serviço de Patrimônio Histórico e Artístico Nacional (SPHAN) criado em 1937 e Fundação Pró-memória, havendo, um incipiente envolvimento da empresa privada. Modificações estruturais do Governo Federal, em 1990, levam também à criação do Instituto Brasileiro de Patrimônio Cultural (IBPC), porém, não necessariamente significando vantagens para a preservação ativa de bens culturais.

No que diz respeito aos bens culturais é sabido que até a primeira metade deste século, praticamente, patrimônio cultural foi sinônimo de obras monumentais, obras de arte consagradas, propriedades de grande luxo, associadas às classes dominantes, pertencentes à sociedade política ou civil. Os prédios considerados merecedores de cuidados especiais e exibição, eram antigos palácios, residências de nobres ou locais onde aconteceram fatos relevantes para a história política de determinado local.

Atualmente, há consenso de que a noção de patrimônio cultural é muito mais ampla, que inclui não apenas os bens tangíveis como os mencionados, mas também os intangíveis, não só as manifestações artísticas, mas todo o fazer humano, e não só aquilo que representa a cultura das classes mais abastadas, mas também o que representa a cultura dos menos favorecidos. 
Assim, vale ressaltar que a política preservacionista oficial acabou privilegiando a proteção e a conservação de monumentos que foram produzidos pelo Estado e Igreja. É claro, que não podemos desvalorizar a importância desse trabalho, mas apenas demonstrar que o interesse com os produtos da cultura popular, que hoje definimos como bens imateriais, é importante.

Verifica-se com isso, que os seres humanos não produzem apenas obras de arte, produzem ciência, sabedoria, história, vestuário, receitas de cozinha, formas de relacionar-se com os vizinhos, enfim, hábitos, usos e costumes. Portanto, modernamente se compreende por patrimônio cultural todo e qualquer artefato humano que, tendo um forte componente simbólico, seja de algum modo representativo da coletividade, da região e da época específica, permitindo melhor compreender-se o processo histórico.

Foi percebendo tal fato, que foi criado então o decreto 3.551, de 4 de agosto de 2000, que instituiu o Registro de Bens Culturais de Natureza Imaterial, como o resultado de um anteprojeto, elaborado por uma comissão nomeada pelo até então ministro da Cultura, o sociólogo Francisco Weffort.

"Por mais oportuno que tenha sido esse Decreto, por mais nobre que sejam os seus objetivos, entre eles o de regulamentar o artigo 216 da Constituição Federal, é ele uma manifestação tardia por parte do Estado em reconhecer o valor do nosso patrimônio cultural imaterial. Oito décadas o separam do anseio dos modernistas preocupados com a valorização de nossa cultura. É verdade que há 66 anos, o Estado brasileiro deu um importante passo ao criar o Serviço de Patrimônio Histórico e Artístico Nacional, mas é verdade também, apesar da presença de Mário de Andrade entre seus fundadores, que o SPHAN preocupou-se predominantemente pela conservação do chamado patrimônio de pedra e cal” (Laraia, 2004, p. 12)

Os bens de natureza imaterial, tal como os entendemos hoje, foram incorporados legalmente à noção de patrimônio cultural no Brasil a partir da promulgação da Constituição Federal de 1988, conforme expressa no artigo 216:

"Constituem patrimônio cultural brasileiro os bens de natureza material e imaterial, tomados individualmente ou em conjunto, portadores de referência à identidade, à ação, à memória dos diferentes grupos formadores da sociedade brasileira, nos quais se incluem:

I. as formas de expressão;

II. os modos de criar, fazer e viver; 
III. as criações científicas, artísticas, tecnológicas;

IV. as obras, objetos, documentos, edificações e demais espaços destinados às manifestações artístico-culturais;

V. os conjuntos urbanos e sítios de valor histórico, paisagístico, artístico, arqueológico, paleontológico, ecológico e científico".

Patrimônio é então uma reserva de valores, uma herança, e hoje, é compreendido não apenas na acepção material (bens móveis e imóveis), mas ainda em sua dimensão imaterial. Bens imóveis como monumentos, edificações, paisagens, sítios arqueológicos ou paleontológicos, ambientes históricos, urbanos e arquitetônicos, tanto quanto bens móveis como um livro, uma obra de arte, um disco, uma foto e as formas de expressar de uma determinada população são bens culturais, impregnados de rico potencial de informações sobre a vida humana, sobre a história do homem e sobre a cultura de cada povo.

A medida legal mais concreta para proteger o patrimônio é o tombamento, que consiste num registro do bem num "livro de tombo", em cujas páginas ficam registrados os bens considerados valiosos e sujeitos às leis de preservação do patrimônio, o que implica em não poderem ser demolidos nem modificados em seu aspecto externo ou em suas características essenciais.

Em relação aos bens imateriais, o registro é a forma de proteção instituída pelo Decreto, mas é importante, que esta proteção não seja entendida como uma forma de congelamento do patrimônio cultural, pois as manifestações populares são componentes vivos de nossa cultura e, portanto suscetíveis de mudanças. A questão positiva do registro é justamente o reconhecimento pelo Estado de sua existência e de seu valor como referência de nossa identidade.

Vale destacar ainda, que quando se pensa em preservar, significa proteger, resguardar e evitar que alguma coisa seja atingida por alguma outra que lhe possa ocasionar dano, ou seja, é o uso de um conjunto de métodos, procedimentos e políticas que visem a proteção em longo prazo. Conservar, por outro lado, significa manter, guardar para que haja uma permanência no tempo. Desta forma, preservar o patrimônio implica mantê-lo estático e intocado, ao passo que conservar implica integrá-lo no dinamismo do processo cultural. 
Acredita-se, que o patrimônio transformado em monumento passou a ser considerado um mediador entre passado e presente, ou seja, uma forma capaz de dar uma sensação de continuidade em relação a um passado, de ser um referencial capaz de permitir a identificação de uma localidade ou de uma nação. A manutenção do patrimônio histórico, em sentido amplo, faz parte então de um processo maior ainda, que são a conservação e a recuperação da memória, graças à qual os povos mantêm sua identidade.

Lê Goff (apud Barretto, 2000, p. 43) lembra que "a memória é um elemento essencial do que se costuma chamar identidade, individual ou coletiva, cuja busca é uma das atividades fundamentais dos indivíduos e das sociedades de hoje, na febre e na angústia”.

A continuidade com o passado nos permite, de uma certa forma, que saibamos mais ou menos quem somos e de onde viemos, ou seja, que tenhamos uma identidade. Recuperar ou manter essa identidade aparece neste final de século, como uma necessidade generalizada em face da globalização.

Conforme Barretto “manter algum tipo de identidade - étnica, local ou regional - parece ser essencial para que as pessoas se sintam seguras, unidas por laços extemporâneos a seus antepassados, a um local, a uma terra, a costumes e hábitos que lhes dão segurança, que lhes informam quem são e de onde vêm, enfim, para que não se percam no turbilhão de informações, mudanças repentinas e quantidade de estímulos que o mundo atual oferece” (2000, p.46).

Identidade e a territorialidade são dois requisitos fundamentais para a definição de uma referência cultural. Essa territorialidade e idéia de lugar apontam para a afirmação social, ou seja, o reconhecimento e pertencimento dos indivíduos a um grupo ou dos grupos a uma sociedade ou nação. Com relação a essa questão, afirma Barretto "além da questão identitária, $a$ recuperação da memória leva ao conhecimento do patrimônio e este, à sua valorização por parte dos próprios habitantes do local” (2000, p. 48).

A recuperação dessa memória coletiva, mesmo que seja para reproduzir a cultura local para os turistas, é sem dúvida benéfica para um determinado lugar. Assim, a busca dos elementos característicos e diferenciais de cada cultura aparece como uma necessidade de mercado, a cultura autóctone é a matéria-prima para a criação de um produto turístico comercializável e competitivo internacionalmente. Como diz Barretto "a identidade turística 
dos lugares é uma construção social, feita de tradições inventadas e de construções culturais atendendo aos mais diversos interesses" (2001, p. 18).

De acordo com Delphim “o patrimônio cultural assume um valor coletivo e constitui a riqueza e a herança mais caras de um povo. Compõe-se de bens que um grupo social produziu ou adquiriu ou elegeu como testemunho de sua cultura. Os bens são uma marca, uma forma de identificar cada cultura. Esses bens devem permanecer além de sua época, devem ser legados de uma geração a outra” (2004, p. 2).

Assim, trabalhar a tradição como atrativo ajuda a recuperar a memória e a identidade local, por isso, cabe ao planejador em turismo a atuação consciente para que o patrimônio, as tradições e o legado cultural como um todo, possam ser transformados num produto turístico de qualidade, bom para ser usufruído também pela comunidade local.

"História, arte, religião, diversão, ecologia, etc. são temas colocados em questão a todos os que chegam ou que ali já estão, formando um manancial de eventos e atrativos que não só permitem o lazer, mas, produzindo um terreno de interação entre pessoas de várias origens, despertam nelas aspectos importantes de suas culturas” (Giovannini, 2001. p.149)

Pensando justamente em trabalhar a tradição como atrativo, foi criado no ano de 1998 o Movimento Pró-Cidade de Goiás, formado por entidades vilaboenses, cuja finalidade era conscientizar a população local sobre as potencialidades turísticas, culturais e artísticas da cidade. O $1^{\circ}$ Seminário Cultural Turístico e Ambiental da Cidade de Goiás, realizado neste mesmo ano, é considerado o embrião do movimento. Inspirado na Serra Dourada e nas cores da bandeira de Goiás, o artista plástico Siron Franco criou a logomarca do movimento em dezembro de 1998.

Vale ressaltar aqui, que a primeira idéia de transformar a Cidade de Goiás em Patrimônio Mundial da Humanidade surgiu já no início da década de 1990. Foi no ano de 1998, que o então governador Maguito Vilela solicitou formalmente ao ministro da Cultura Francisco Weffort, a candidatura de Goiás a Unesco, no mesmo ano em que foi criado esse movimento.

O Movimento Pró-Cidade de Goiás foi uma forma de estar valorizando a tradição da cidade e sua importância histórica, dentro do contexto nacional e internacional, sugerindo que 
a mesma viesse a ser tombada pela Unesco, portanto, de uma certa forma, ajudando a recuperar a identidade local.

É através de seus museus, igrejas, suas manifestações culturais, sua culinária e o modo de viver do povo vilaboense, com seus hábitos e costumes que se estará fortalecendo a identidade do município, valorizando sua cultura e conseqüentemente permitindo a prática do turismo local, com base em todo esse legado cultural.

Como diz o músico Paulinho da Viola "não vivo no passado, é o passado que vive em mim”. Exatamente por considerar este aspecto, creio que os moradores da cidade deverão entender que a valorização do passado enriquece mais ainda a memória coletiva e identifica o cidadão dentro de um contexto histórico e cultural.

Enfim, o título de Patrimônio Mundial da Humanidade concedido a Cidade de Goiás, foi uma forma dos moradores se sentirem mais valorizados e desta forma, mais dispostos a continuar mantendo as características que lhes são próprias, e conseqüentemente, fortalecendo a identidade local principalmente por meio da atividade turística.

\section{3 - O Patrimônio Cultural e Natural do Município}

Proteger a cultura e a natureza exige um grande esforço das pessoas. É importante se preservar toda essa riqueza, pois só assim, o homem continuará a aprecia-la e a valoriza-la. Desta forma, sentindo essa necessidade de se preservar tanta riqueza, no ano de1972, como já dito no tópico anterior deste capítulo, a UNESCO criou um tratado internacional denominado “Convenção sobre a Proteção do Patrimônio Mundial Cultural e Natural”.

Essa Convenção é parte de um esforço internacional na valorização de bens, que por sua importância para a referência e identidade das nações, possam ser considerados patrimônio de todos os povos.

A Convenção entrou em vigor em 1975, quando 20 nações assinaram o termo de adesão, e em 1976, foi criado o Comitê do Patrimônio Mundial, constituído por técnicos representantes dos países que aderiram à Convenção. A esse Comitê compete organizar seu 
regulamento interno, definir critérios e realizar a seleção dos bens a serem inscritos nas Listas do Patrimônio Mundial e do Patrimônio Mundial em Perigo. Cabe também ao Comitê definir a alocação das verbas do Fundo do Patrimônio Mundial, formado pela contribuição dos países membros.

Participam do Comitê, como consultores para a cultura, os representantes do Conselho Internacional de Monumentos e Sítios (ICOMOS) e do Centro Internacional de Estudos para a Conservação e Restauração de Bens Culturais (ICCROM) e, para a natureza, da União Internacional para a Conservação da Natureza (IUCN).

Antes, porém, é bom se questionar como se chegou a essa Convenção de 1972, ou seja, qual a importância de se associar o patrimônio cultural com o natural. De acordo com a própria Unesco "a idéia de se criar um movimento internacional para a proteção de sítios em outros países surgiu após a Primeira Guerra Mundial, nascendo de dois movimentos distintos: o primeiro, que dava ênfase ao perigo que cercava os sítios culturais, e o segundo, que se ocupava da conservação da natureza”.

Assim, o acontecimento que resultou na preocupação internacional mais acentuada, foi a decisão de se construir uma grande represa no Egito, a qual inundaria um vale onde se encontravam templos, que representavam um tesouro da antiga civilização egípcia. Desta forma, em 1959, a UNESCO, decidiu lançar uma campanha internacional a partir da convocação dos governos do Egito e do Sudão, para acelerar a investigação arqueológica nas áreas que seriam inundadas. Tais templos tiveram que ser desmontados, transportados a um terreno seco e lá remontados, em uma campanha que teve um custo de cerca de 80 milhões de dólares, cuja metade desse valor, foi doada por cerca de 50 países. Isso acabou demonstrando a importância da responsabilidade compartilhada entre as nações para a conservação desses sítios.

Algum tempo depois, a UNESCO iniciou com a ajuda do ICOMOS, a elaboração de um projeto de convenção sobre a proteção do patrimônio cultural. Já a idéia de combinar a conservação dos sítios culturais e naturais foi dos Estados Unidos no ano de 1965, em uma conferência na Casa Branca, em Washington que se pediu que se criasse uma "Fundação do Patrimônio Mundial”, que estimulasse a cooperação internacional para proteger as zonas naturais e paisagísticas mundiais consideradas excepcionais. Em 1968, a União Internacional 
para a Conservação da Natureza e seus Recursos (UICN) elaborou propostas similares para seus membros, as quais foram apresentadas na Conferência das Nações Unidas sobre Meio Ambiente em Estocolmo no ano de 1972.

Assim, os países signatários dessa Convenção podem indicar bens culturais e naturais a serem inscritos na Lista de Patrimônio Mundial. As informações sobre cada candidatura são avaliadas por comissões técnicas e a aprovação final é feita anualmente pelo Comitê do Patrimônio Mundial.

Os sítios selecionados para inclusão na Lista do Patrimônio Mundial são aprovados com base em suas qualidades como melhores exemplos possíveis de patrimônio cultural e natural. E, é nessa lista, que se irá destacar a riqueza e a diversidade do patrimônio cultural e natural do nosso planeta. Entretanto, vale ressaltar, que a proteção e a conservação dos bens declarados Patrimônio da Humanidade é compromisso do país onde se localizam. A Unesco participa apoiando ações de proteção, pesquisa e divulgação com recursos técnicos e financeiros do Fundo do Patrimônio Mundial, como já mencionado anteriormente.

Mas o que seria esse tão falado Patrimônio?

Por Patrimônio cultural entende-se um conjunto de bens materiais (móveis e imóveis), como monumentos, obras de arte, fotos antigas, grupos de edifícios e sítios que tenham valor histórico, estético, arqueológico, científico, etnológico ou antropológico e bens imateriais como as formas de expressão do homem. Já o Patrimônio natural são as formações físicas, biológicas ou geológicas consideradas excepcionais, habitats, animais e vegetais ameaçados e áreas que tenham valor científico, de conservação ou estético. O Patrimônio é o legado que recebemos do passado, o qual vivemos no presente e que transmitimos às gerações futuras. Nosso patrimônio cultural e natural é uma fonte insubstituível de vida e inspiração representando a nossa identidade, tema discutido no tópico anterior desse capítulo.

O que faz com que o conceito de Patrimônio Mundial seja excepcional é sua aplicação universal. Os sítios do Patrimônio Mundial pertencem a todos os povos do mundo, independente do território no qual estão localizados, ou seja, isso significa que um sítio egípcio do Patrimônio Mundial pertença da mesma forma aos egípcios, bem como a outros povos do mundo, isto porque, a "Convenção sobre a Proteção do Patrimônio Mundial 
Cultural e Natural” através do qual, os países reconhecem que os sítios localizados em um território nacional, e inscritos na Lista do Patrimônio Mundial (sem perda da sua soberania), constituem um patrimônio universal, com cuja proteção toda a comunidade internacional deve cooperar.

Sem o apoio de outros países, alguns sítios de reconhecido valor cultural ou natural já teriam deteriorado-se ou desaparecido, provavelmente devido à falta de fundos para sua preservação. A Convenção é, dessa forma, um acordo para fornecer os recursos intelectuais necessários à proteção dos sítios do Patrimônio Mundial. Todos os países possuem sítios de interesse local ou nacional, que constituem motivo bem justificado de orgulho nacional, e a Convenção, os estimula a identificar e proteger seu patrimônio, esteja esse incluído ou não na Lista do Patrimônio Mundial. Hoje, existem aproximadamente 721 sítios inscritos na Lista do Patrimônio Mundial.

"No Brasil, dezessete bens brasileiros já foram inscritos na Lista. Esses sítios refletem o esforço de construção de uma lista equilibrada, capaz de representar a notável diversidade cultural e natural do país. Especialmente após a inscrição, recente e há muito esperada, de sítios naturais emblemáticos, como é o caso da Amazônia e Pantanal, chegou-se a esse desejado equilíbrio. Atualmente, o conjunto de bens brasileiros, distribuídos entre dez sítios culturais e sete naturais, contempla situações variadas como Brasília, a capital federal com arquitetura modernista, o préhistórico Parque Nacional da Serra da Capivara, a Costa do Descobrimento, com sua singular simbiose entre natureza e cultura, e Goiás, representativa de técnicas e tradições vernaculares” (Bouchenaki, 2002, p.6).

Portanto, considerando-se ambos os aspectos natural e cultural do patrimônio, a Convenção, lembra-nos a forma como o homem interage com a natureza e ao mesmo tempo a necessidade fundamental de se preservar o equilíbrio entre ambos.

A crescente adesão de países e inscrição de novos sítios nos permite afirmar que este é o instrumento internacional de maior difusão e aceitação entre os propostos pela Unesco. Vale lembrar, que pessoas físicas e jurídicas devem trabalhar em conjunto para preservar esses sítios. O Brasil é um dos países que vem demonstrando e provando seu profundo interesse em reviver e manter suas tradições e conhecimentos, e ainda, o seu meio ambiente tão abundante e diversificado que o mundo sempre admirou. 
"Os sítios naturais e culturais que o Brasil se empenhou em inscrever na Lista do Patrimônio Mundial são os lugares que o país escolheu não apenas para deles se lembrar, mas também para, por meio deles ser lembrado e compreendido. Lugares pelos quais se expressam suas formas de existência, sua relação com a história, com a cultura e com o ambiente" (Albuquerque e Werthein, 2002, p.10).

Em 1980, a cidade de Ouro Preto (MG) foi apresentada pelo Brasil para ser inscrita na Lista do Patrimônio Mundial como obra-prima da criação humana, um núcleo urbano excepcional e íntegro do período do Ciclo do Ouro do século XVIII. Seqüencialmente outras regiões do país foram sendo inscritas na Lista, como por exemplo, O Centro Histórico de Olinda (PE), as ruínas de São Miguel das Missões (RS), um dos Sete Povos das Missões Jesuíticas, o Centro Histórico de Salvador, o Conjunto Urbanístico do Plano Piloto da cidade de Brasília, entre outros.

Em 2000, o Centro Histórico da Cidade de Goiás foi indicado na Lista de Patrimônio Mundial, que perfaz uma área de 40,3 hectares. Com seu traçado e sua arquitetura, a cidade histórica de Goiás constitui um notável exemplo de núcleo urbano com características européias, admiravelmente adaptadas às condições climáticas, geográficas e culturais da área central da América do Sul. A cidade também apresenta a evolução de uma estrutura urbana e arquitetônica representativa da colonização da América do Sul, que fez uso completo dos materiais e técnicas disponíveis, em meio a uma paisagem excepcional e bastante conservada.

Um fato interessante é com que a mudança da capital de Goiás para Goiânia, na década de 1930, a velha cidade, ficou desfalcada de gente, de recursos econômicos e financeiros, e em um breve período passou por um processo de desfiguração e mesmo de destruição acentuada. Desde esse momento, porém, o IPHAN começou a cuidar desse patrimônio, dando assim, sinais de reação e recuperação.

A Cidade de Goiás faz parte, juntamente com outros centros goianos, do legado do ciclo do ouro. Objeto de duas ações de proteção de seu patrimônio histórico nos anos de 1950 e 1978, por legislação federal, a Cidade de Goiás representa uma das cidades brasileira mais interiorana a merecer uma especial atenção, devido ao seu patrimônio plural e às condições que vêm condicionando o seu desenvolvimento através dos séculos. 
Entre 1950 e 1951, o IPHAN tombou como monumentos históricos as principais igrejas de Goiás, o Quartel do XX, a Casa de Câmara, o Palácio Conde dos Arcos, o Chafariz de Cauda e a Rua da Fundição. Em seguida, no ano de 1978, o Conjunto Arquitetônico e Urbanístico da Cidade de Goiás foi tombado. Em 1996, foi elaborado o Plano Diretor da cidade, e nesse mesmo ano, a candidatura da Cidade de Goiás ao título de Patrimônio Mundial promoveu o significativo crescimento dos investimentos privados direcionados à sua preservação. Ressalte-se a isso as ações do Estado, como a retirada da fiação aérea no Centro Histórico. Já no ano de 1998, um decreto estadual ampliou a Área de Proteção Ambiental da Serra Dourada, assegurando a permanência da paisagem preservada, desde o centro até o cume da serra.

A obtenção do título, em 14 de dezembro de 2001, deu-se em um primeiro momento, graças a esse esforço da década de 1950, o que tem permitido que a Cidade de Goiás preserve a singularidade de seu patrimônio. Esta foi também uma conquista de luta coordenada pelo Movimento Pró-Cidade de Goiás, portanto, o processo envolveu um conjunto de órgãos e entidades e cumpriu um roteiro de ações definidas no Dossiê de Goiás, documento que reuniu informações diversas sobre a antiga capital do Estado, da história à arquitetura, do meio ambiente à população e à cultura.

Quanto às singularidades mencionadas anteriormente, podemos destacar que os primeiros arruamentos do Arraial de Sant`Ana, surgido às margens do Rio Vermelho nos primórdios da mineração, se organizaram em três sentidos: em direção a sudeste, isto é, dos caminhos vindos de São Paulo, em direção ao norte e a oeste, rumo à Cuiabá. Assim, ruas e becos se implantaram, sem formar os tradicionais ângulos retos. Esse planejamento não ortogonal resultou da interligação dos três largos de formato triangular, onde foram espontaneamente se instalando os edifícios do poder, de culto e, à sua volta, o casario.

Permanece íntegro esse traçado urbano com seu calçamento em pedras irregulares, emoldurado a leste e ao norte pelos morros São Francisco e Cantagalo, e ao sul pelos longos contrafortes da Serra Dourada, que conferem ao sítio histórico, nas palavras do arquiteto Augusto da Silva Telles, “um valor paisagístico suplementar por seu caprichoso perfil no horizonte, pelo colorido que apresenta a partir dos reflexos dos raios solares e pela massa arbórea que a encobre parcialmente”. 
Por isso, é bom lembrar que a Cidade de Goiás foi inscrita na lista do Patrimônio Cultural, mas não sem antes estabelecer todos os mecanismos necessários à proteção de sua paisagem e do ambiente natural no seu entorno, portanto, tentando o caminho da preservação sustentada, onde natureza, cultura e desenvolvimento são reconciliados.

Detentora de um traçado orgânico adaptado às condições topográficas do sítio e à fundamental presença do Rio Vermelho, Goiás apresenta um esquema urbano, que não teve alterações desde o século XVIII. Por conta do isolamento dos principais centros culturais do Brasil colonial, a arquitetura, tanto dos prédios públicos quanto dos privados, é bastante austera, com apenas ligeiras diferenças entre prédios "monumentais" e "menores", e com soluções técnicas particulares, que colocam Goiás como um exemplo relevante da arquitetura vernacular.

Ao mesmo tempo, considerando a cidade como um processo vivo, em vez de um objeto, é lógico que algumas mudanças ocorreram, incluindo a perda ou alteração de alguns prédios significativos, mas essas mudanças, que aconteceram principalmente na primeira metade do século XX, não alteraram a extraordinária unidade do conjunto. A extensão da cidade durante o final do século XIX e no século XX não introduziu insensíveis mudanças de escala. É excepcional essa relação entre a cidade e o ambiente, ou seja, um território natural de significante beleza, exemplo típico da paisagem do Brasil Central.

“Cochichando uma com as outras”, no dizer da poetisa Cora Coralina, as casas se abrem diretamente para a rua, em cadenciamento constante de portas e janelas, cujo número depende da largura dos lotes. Esses, de modo geral, são estreitos e compridos, estendendo-se da rua com a fachada até o muro dos fundos, limitando quintal e pomar. Um portão nesse muro em taipa ou adobe se abre para os becos, que hoje chamaríamos de ruas de serviço.

Da mesma forma, a arquitetura religiosa prima pela simplicidade, ainda que os forros pintados das igrejas de São Francisco e de Nossa Senhora d`Abadia e o frontão da Igreja da Boa Morte demonstrem certa erudição. Os edifícios públicos e moradas são feitos de pau-apique, taipa ou adobe, em sua maioria, sem ornamentação significativa. Apenas no interior das igrejas notam-se traços de um barroco tardio, expressos em imagens, talhas e pinturas, encomendadas aos poucos artesãos residentes na região pelas irmandades religiosas. 
As construções religiosas de maior porte são, em geral, feitas em taipa de pilão ou pedra, e as mais simples, em adobe. A maioria dessas edificações data da segunda metade do século XVIII, quando o ouro já se encontrava em processo de esgotamento. Talvez, por isso, os elementos decorativos e estéticos não se vinculam, formal e plasticamente, aos edifícios característicos das ordens religiosas estabelecidas no litoral da colônia. Assemelha-se mais à primeira fase da arquitetura religiosa de Minas Gerais.

No momento atual, outro ponto a se destacar é a valorização do patrimônio imaterial, ou seja, os ritos, práticas e conhecimentos tradicionais das populações inseridas nos sítios objeto de preservação. Em sintonia com as políticas da UNESCO, o Ministério da Cultura deu um passo importante ao propor o registro e a política de valorização do patrimônio imaterial brasileiro, representados pelo Decreto Presidencial $n^{0}$ 3.551, promulgado em 2000. Assim, a cidade de Goiás integra bem essa idéia, isto porque, além da arquitetura civil e religiosa de caráter vernacular e do acervo de suas igrejas - imagens, talhas e pinturas - Goiás tem rica vida social e cultural e preserva importantes tradições, algumas das quais mescladas a elementos profanos do folclore local, como é o caso das celebrações da Semana Santa com a Procissão do Fogaréu.

A riqueza cultural da Cidade de Goiás pode ser atestada através de seus pintores, músicos e musicistas, poetas e tantos mais. Referência especial cabe citar ao artista genial José Joaquim da Veiga Valle. No tocante às letras, destaca-se Hugo de Carvalho Ramos, e a poetisa Cora Coralina. Encontramos ainda Goiandira Aires do Couto pintando com as areias da Serra Dourada os casarios de Villa Boa, entre outros.

"Goiás detinha uma nata intelectual, que apesar de pequena, de cultura tão refinada quanto a melhor do Brasil. Alegre, o povo goiano tinha suas festas, muitas de cunho popular, como cavalhadas, congadas, reisados, malhação de Judas, Zé-pereira, e também as eruditas, como bailes em casas particulares e no palácio, recitação de poemas audições musicais” (Élis, 1979, p. 21).

Certamente que as condições de isolamento não permitiram criar em Goiás aquele espetáculo de esplendor das velhas cidades mineiras e litorâneas, mas o espírito e a cultura mestiça geraram ali características próprias definitivas e únicas. Sua cultura é essencialmente brasileira, tanto no material como no espiritual. 
Segundo Élis (1979, p. 22) “em Goiás, a arte se apresenta caldeada dentro do temperamento mestiço nacional e afeiçoada às nossas peculiaridades mais estranhamente brasileiras. Se pobre, o barroco, apresenta o essencial, esse espírito complexo e contraditório, gerador das ruas tortuosas, do calçamento incerto, da predominância de linhas curvas, do casario pequeno e de paredes-meias, enfim, esse clima, esse ar sensual e místico, em que o pecado e as penas se temperam com o ardente impulso de gozar a vida naquelas melhores coisas que Deus deixou no mundo para os homens e para os bichos. É com ternura que se sente a simplicidade aparente de Villa Boa, atual Cidade de Goiás”.

Os sitos brasileiros do Patrimônio Mundial, (como é o caso da Cidade de Goiás), são peças fundamentais no mosaico da diversidade cultural e natural do Brasil e do mundo, mas ao mesmo tempo, são também instrumentos de promoção de bem estar social, de participação, de cidadania, de incremento do turismo cultural e ecoturismo, e justamente por isso tenho a convicção de que Goiás não pode viver apenas de seu passado, pelo contrário, deve cada vez mais fortalecer sua identidade e originalidade, aproveitando sua riqueza histórica e cultural em prol do fomento da atividade turística, já que, na Cidade de Goiás, o que não falta é atração para os turistas.

Portanto, o título de Patrimônio Mundial da Humanidade, mostra a importância das pessoas valorizarem seu patrimônio e como a população deve dar continuidade, buscando enriquecer cada vez mais a história de um povo.

Mais do que se deleitar com o conjunto arquitetônico da cidade, hoje os moradores com seus quitutes da terra, com suas tradições folclóricas como a Procissão do Fogaréu, com seu artesanato arraigado pela mistura de índios, negros e brancos, deve criar uma identidade que permita fazer do turismo mais uma das atividades econômicas da cidade e que realmente mostre esse traço cultural característico do povo goiano.

Segundo Aristóteles, “a memória é um lugar da alma a ser visitado”, por isso, no próximo tópico deste capítulo estarei abordando a questão da visitação turística, demonstrando os principais atrativos da Cidade de Goiás, ou seja, a importância de se divulgar a cidade e fazê-la conhecida aos olhos do Brasil e do mundo. 


\section{4 - A Prática do Turismo Local}

A Cidade de Goiás é lembrada como uma típica representante do Brasil Colonial, e de certa forma, quando se pensa nessa cidade, geralmente a primeira idéia que vêm em nossas mentes é a riqueza histórica e cultural do município. E foi particularmente através do turismo que a cidade foi sendo conhecida, onde visitantes das mais diferentes regiões de nosso país e do mundo se dispuseram a visitá-la. Atualmente os turistas podem encontrar diversas opções de lazer e atrativos na Cidade de Goiás, dentre as quais vale destacar:

\section{Nas artes}

Veiga Valle é o maior artista de todos os tempos em Goiás, cujo acervo, formado por imagens de santo em estilo barroco, está no Museu de Arte Sacra da Boa Morte. Kleber Gouveia, que era um grande pintor de quadros e Goiandira Aires do Couto, outra artista consagrada da região, que pinta seus quadros com areia colorida que recolhe da Serra Dourada, também são representantes da arte da cidade. Além disso, nasceu em Goiás a poetisa Cora Coralina, expressão maior da poesia goiana com a beleza e sutileza de seus versos.

Na Cidade de Goiás, o artesanato é outro fator importante que é enriquecido pela marcante mistura de índios, negros e brancos, assim, no ano de 1976 foi criada a Associação de Artesãos. Dos diversos povos indígenas que habitaram a região, veio a cestaria e os trabalhos em madeira, mas sem dúvida, é a cerâmica que mais caracteriza o povo goiano, sendo esta, feita ainda totalmente de forma manual pelo artesão, em que as peças se dividem em utilitárias, decorativas e figurativas, exatamente com o mesmo objetivo que eram produzidas pelos índios e que podem ser encontradas nas lojas de artesanato da cidade.

\section{Na arquitetura}

A cidade possui grande quantidade de casas e edificações da época colonial, entretanto, somente algumas dessas obras arquitetônicas estão descritas abaixo, dentre as quais: 
- Coreto do Jardim

O coreto atual foi construído na gestão do prefeito Lincoln Caiado em 1923, e está situado na praça Dr. Tasso Camargo, no antigo Largo da Matriz.

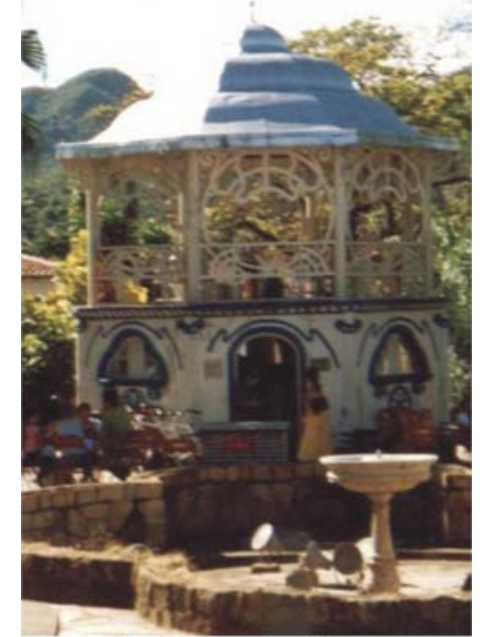

Foto 01: Fernanda Lima

- Mercado Municipal

Criado em 1857, o mercado passou por uma grande reforma em 1925, tendo sido reinaugurado em 1926.

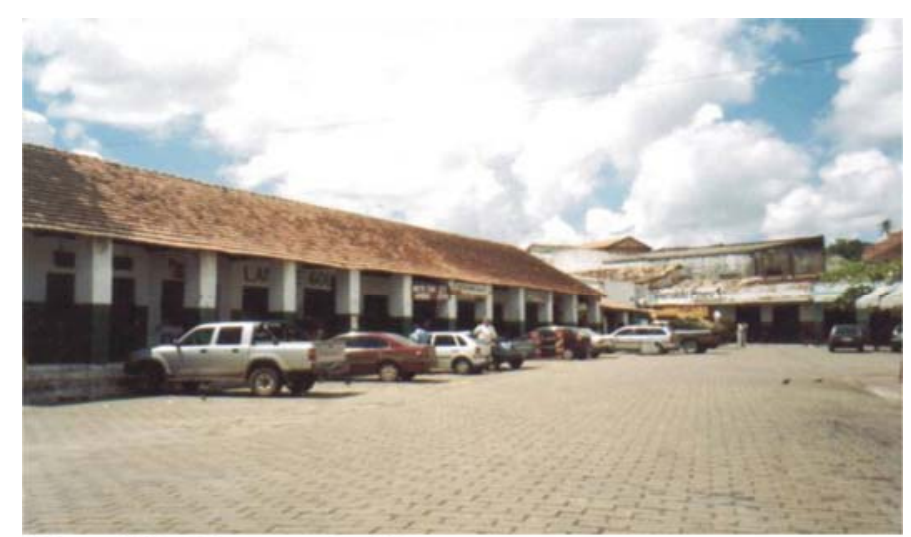

Foto 02: Fernanda Lima 
- Chafariz de Cauda da Boa Morte

Foi construído em 1778 para abastecer as casas do lado de Sant'Ana, sobre os alicerces da primeira capela da Boa Morte, sendo o único chafariz de cauda. Está localizado na Praça Dr. Brasil Caiado.

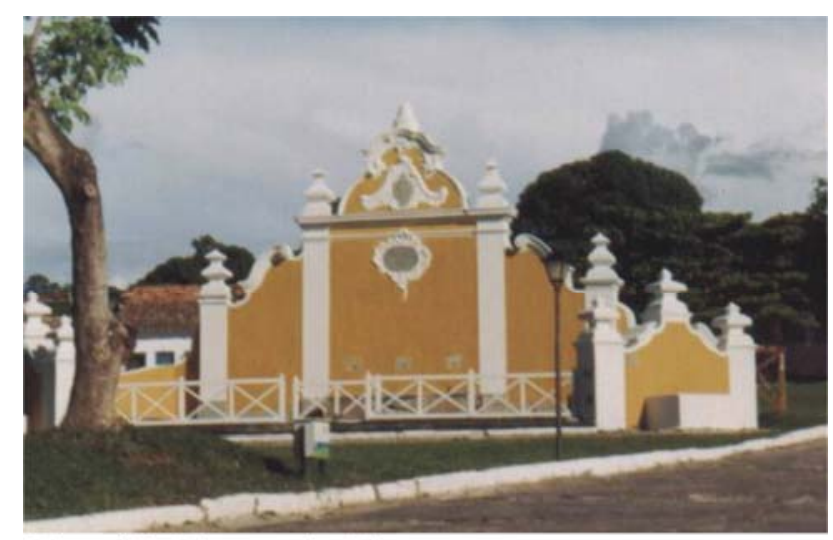

Foto 03: Fernanda Lima

- Quartel do XX

Situado na Praça Dr. Brasil Caiado foi edificado em 1747 para abrigar as Tropas de Linha. Hoje, o Quartel está reformado e aberto à visitação pública.

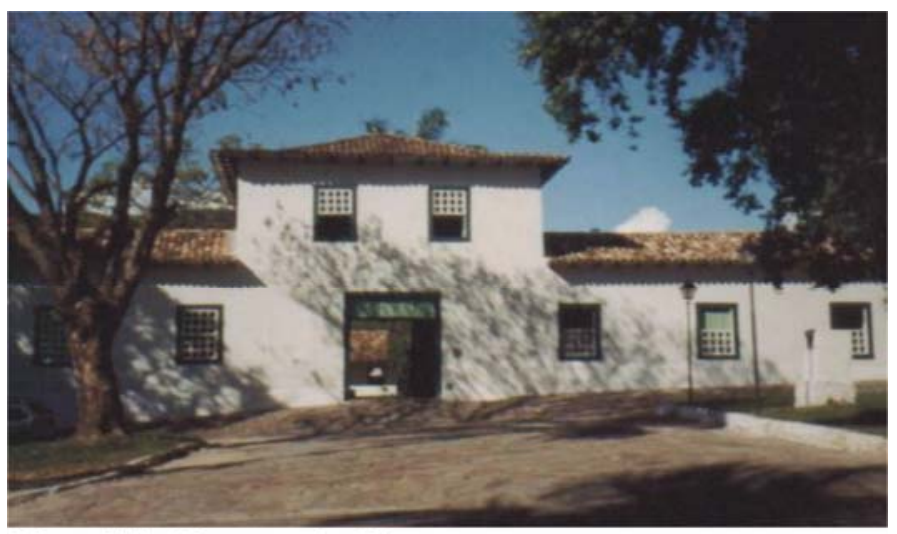

Foto 04: Fernanda Lima

Além destes, museus e igrejas são uma ótima pedida para os turistas que visitam a Cidade de Goiás, dentre os quais:

- Museu das Bandeiras

É um dos prédios históricos mais importantes do Centro-Oeste, principalmente pelo papel que teve na antiga capital. Foi construído em 1761, durante o Reinado de D. José e administração do governador goiano João Manoel de Melo para abrigar a Casa de Câmara e 
Cadeia, com projeto enviado pela corte especialmente para esse fim. A antiga Casa de Câmara e Cadeia segue algumas normas próprias desse tipo de edificação da época, em que no térreo encontra-se a cadeia e, no pavimento superior, alcançado a partir de uma escada de madeira estão os amplos salões que eram destinados às atividades legislativa e judiciária da antiga capital. Um dado interessante, é que o acesso às salas da prisão era feito originalmente por alçapões no piso do pavimento superior. O museu fica na Praça Dr. Brasil Caiado.

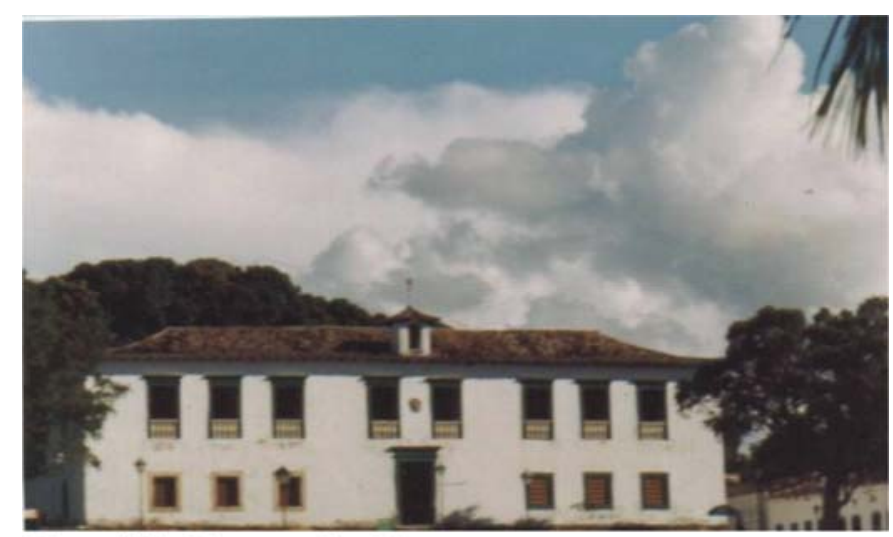

Foto 05: Fernanda Lima

- Palácio Conde dos Arcos

É também um dos prédios mais significativos da história goiana, tendo sido construído entre 1755 e 1759. Dom Marcos de Noronha, o Conde dos Arcos, tomou posse como primeiro governador geral da Capitania de Goiás em novembro de 1749 e ao chegar a Villa Boa, não encontrando nenhuma residência à altura de abrigar um governador comunicou tal fato a D. João que então, autorizou a construção da residência oficial em 1750. O prédio foi ampliado em 1867, com a construção de um terraço lateral.

Com a mudança da capital para Goiânia, em 1937, o Palácio passou a abrigar a prefeitura municipal de Goiás. Já no ano de 1961, o local foi transformado em monumento histórico. Algumas peças do mobiliário foram adquiridas em 1962, durante outra reforma, e em 1979 o prédio transformou-se em um centro cultural e hoje, um dos museus da cidade. Está localizado em frente a Praça Dr. Tarso Camargo, antigo Largo da Matriz. 


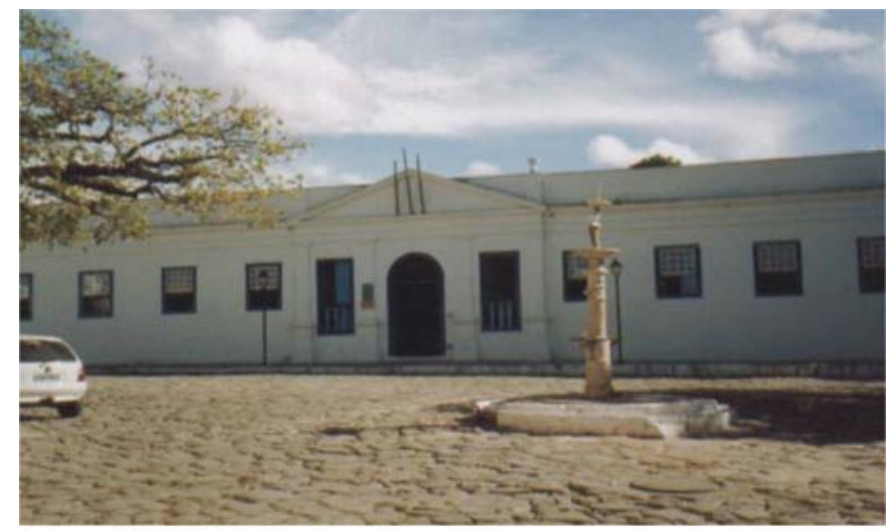

Foto 06: Fernanda Lima

- Museu Casa de Cora Coralina

A casa da escritora Cora Coralina representa o modelo típico da arquitetura residencial desenvolvida no Brasil no período colonial. O edifício é composto de duas residências unidas por um único telhado e apresenta dois corredores que fazem a ligação entre a via pública e o interior das residências. A construção é feita com estrutura autônoma de madeira e paredes de adobe e pau-a-pique, sobre alicerces de pedras, criando com isso uma muralha de contenção para as águas do Rio Vermelho.

Levantamentos realizados pelo IPHAN revela que este edifício teria sido construído em período anterior a 1782, cujo construtor teria sido o português Antônio de Souza Telles, seu primeiro proprietário, e que posteriormente, no início do século XIX teria sido adquirido pela família de Cora, onde seu avô teria passado toda sua infância, assim como sua mãe, e ela própria, sendo hoje aberto a visitação pública, estando localizado na ponte da Lapa, na Rua Cândido Penso n. 22.

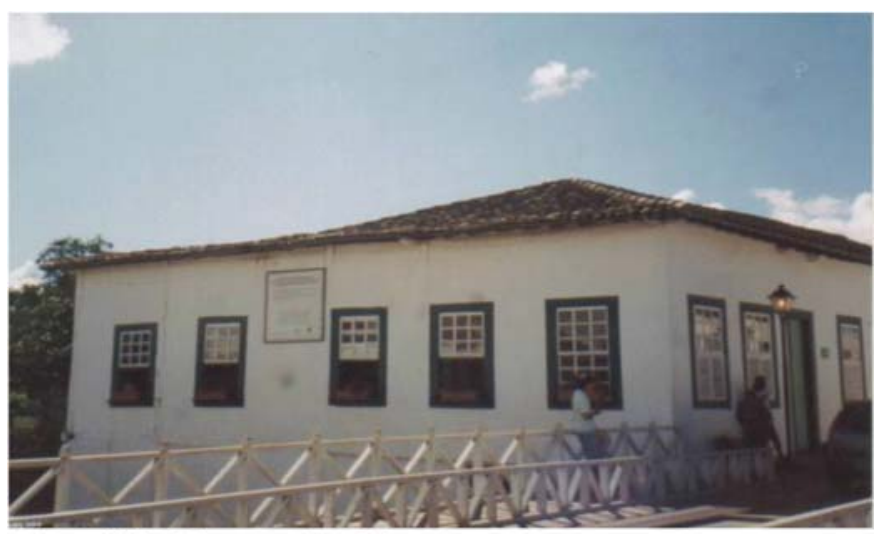

Foto 07: Fernanda Lima 
- Museu de Goiandira Aires do Couto

Com 89 anos de idade, a artista plástica e professora aposentada, pinta suas telas com areias da Serra Dourada, com mais de 500 tonalidades de cores. Suas obras ganharam o mundo e se transformaram em um dos produtos mais requisitados por quem passa pela Cidade de Goiás. Goiandira tem um ateliê em sua casa, que até recentemente era visitado pelos turistas, mas atualmente está disposto à visitação, um espaço, que é separado de sua residência, ou seja, foi criado o Museu Goiandira do Couto, localizado na Rua Joaquim Bonifácio.

- $\quad$ Museu de Arte Sacra da Boa Morte

O Museu de Arte Sacra da Boa Morte foi construído em 1779, como Igreja da Boa Morte, em estilo colonial. A antiga igreja tem paredes em taipa de pilão e seu interior possui uma nave central octogonal, decorado com elementos florais e torre sineira isolada do edifício. Um incêndio destruiu o detalhado e o forro em 1920, e reconstruída, permaneceu como templo religioso até 1967, sendo transformada em museu no ano de 1969 e hoje possuindo em seu acervo obras do artista Veiga Valle. Também localizado no antigo Largo da Matriz na Rua Luiz do Couto.

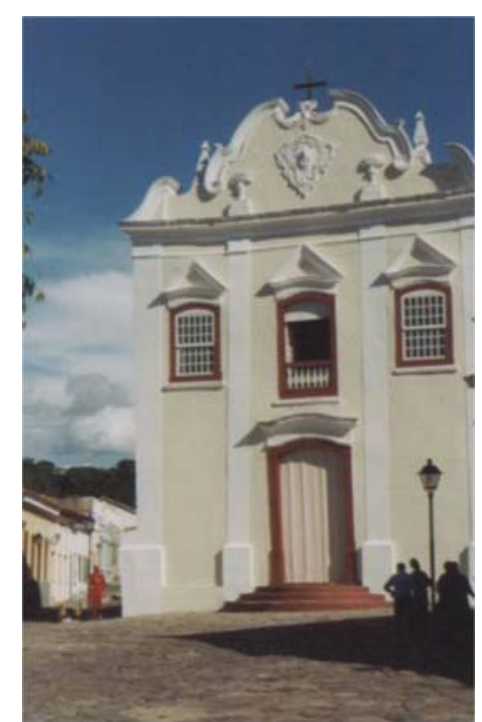

Foto 08: Fernanda Lima

- Matriz de Santana

Em 1727 foi erguida a Capela de Santana, sendo que somente no ano de 1743 foi demolida para a construção definitiva da matriz. A igreja sofreu danos artísticos, mais precisamente em seu teto no ano de 1759 sendo reconstruída sem o forro do teto três anos 
depois. No ano de 1874, novamente ocorreu um novo desabamento com total perda dos ornamentos internos, vindo a ser reconstruída no ano de 1970. Situado no antigo Largo da Matriz.

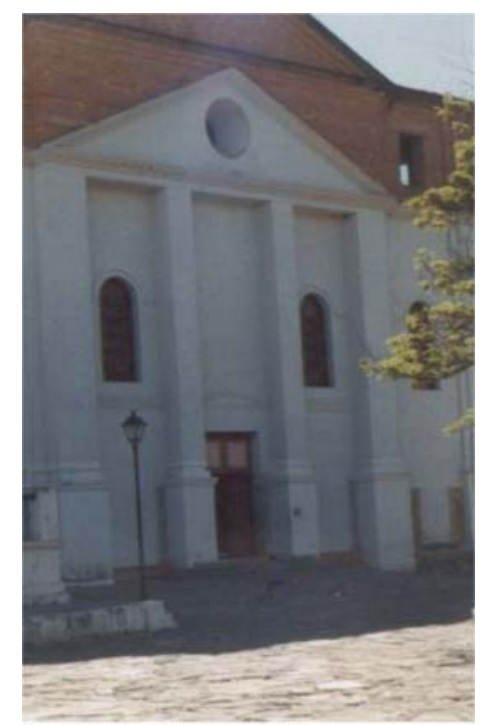

Foto 09: Fernanda Lima

- Igreja Nossa Senhora do Rosário dos Pretos

A Igreja pertencia a Irmandade dos pretos, tendo sido erguida em 1743 por Antônio Pereira Bahia em feição definitiva. Foi demolida em 1934 e reedificada em estilo renascentista pelos dominicanos. Ao lado da igreja está o convento do Rosário onde funciona a Associação dos Artesãos de Goiás.

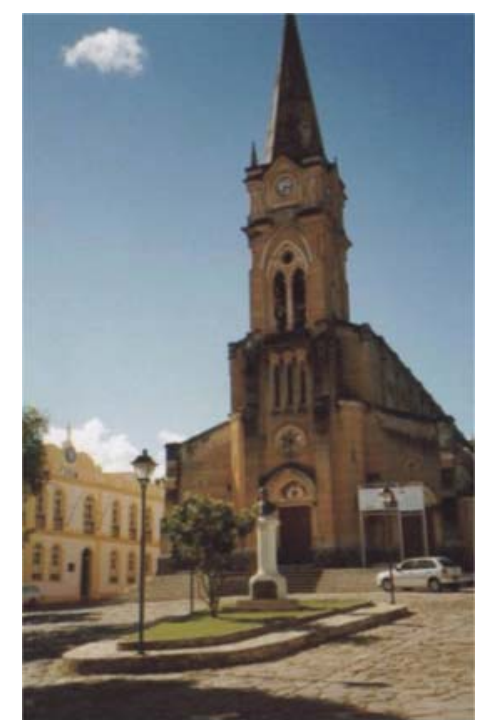

Foto 10: Fernanda Lima 
- Igreja São Francisco de Paula

Erguida por Antônio Tomás da Costa em 1761, no largo de acesso ao mercado atual. Com fachada simples colonial e campanário de madeira lateral. A igreja é hoje sede atual da Irmandade de Senhor dos Passos e possui rica alfaia (móveis, utensílios, paramentos). Está localizada na Praça Zacheu Alves na Avenida Sebastião Fleury.

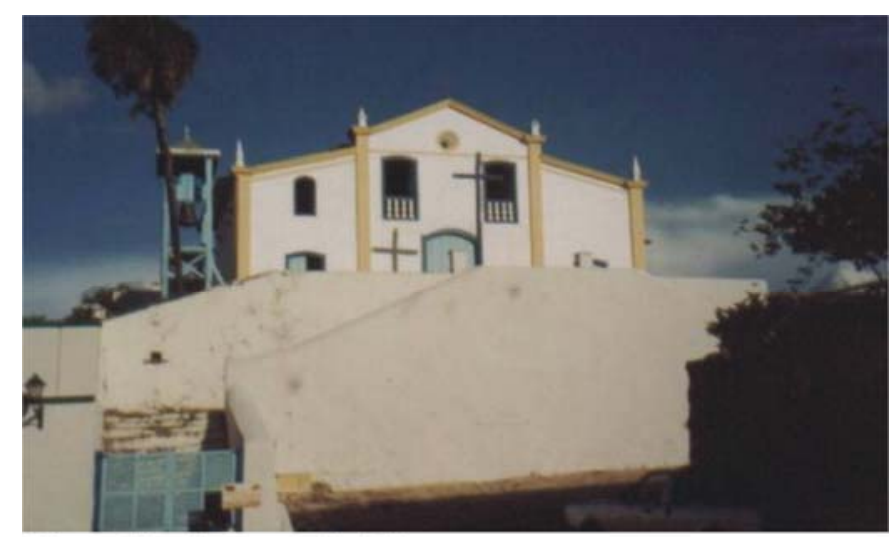

Foto 11: Fernanda Lima

- Igreja Santa Bárbara

Edificada numa colina fora da cidade, em 1780, por Cristóvão José Ferreira. A estrutura da fachada foi alterada. O altar é modesto barroco-rococó. Destaca-se na igreja, a presença de um par de anjos (sem asas) e deformados pelo acúmulo de mãos de tinta. A imagem de sua padroeira é de autora do escultor Veiga Valle.

- Igreja Nossa Senhora do Carmo

Fundada pelo secretário do governo Diogo Luís Peleja, teve Irmandade de Pretos de Santa Ifigênia e, por falta de patrimônio e rendimento, foi concedida à Confraria de São Benedito dos homens pretos crioulos, em 1786, data talvez da concessão e não da construção. A talha dos três altares é uma mistura de rococó com a sobriedade do neoclassicismo. Está localizada ao lado do Hospital São Pedro na Rua do Carmo. 


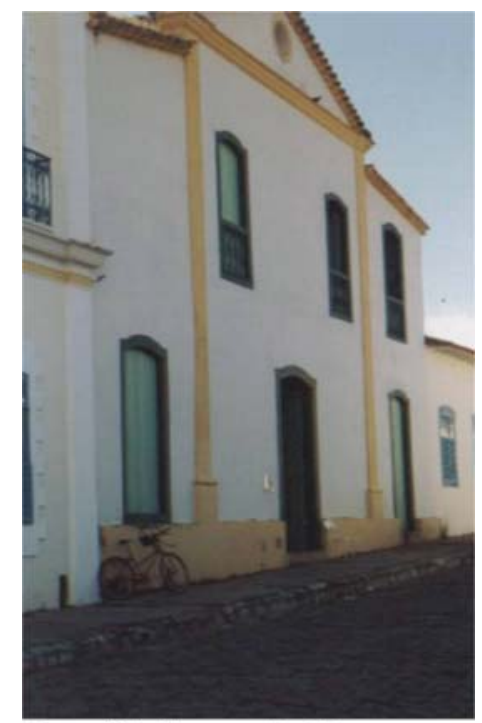

Foto 12: Fernanda Lima

- Igreja Nossa Senhora da Abadia

Foi fundada com esmolas do povo pelo Reverendo Dr. Salvador dos Santos Batista, em 1790. Existe uma harmonia de proporções de um barroco modesto, mas bem distribuído. Esta pequena igreja foi restaurada pelo Patrimônio e recolocada em seu aspecto original, apresentando policromia de belo efeito, com restos de douração. Está localizada na esquina da Rua dos Bancários.

- Igreja Nossa Senhora Aparecida

Foi construída em 1910 e está localizada no povoado de Areias a 10 km da Cidade de Goiás, na GO - 070.

\section{Na Culinária}

Quem quiser conhecer a culinária vilaboense tem que apreciar o arroz com pequi, arroz com guariroba, o empadão goiano, o bolo de arroz, o alfenim (doce típico local), e degustar também, os licores de pequi, de caju, de jenipapo, bem como, os doces cristalizados da terra. Existe uma boa quantidade de restaurantes e bares na cidade.

\section{Nas Manifestações populares}

A Cidade de Goiás proporciona o espetáculo maravilhoso da Semana Santa, principalmente, a impressionante Procissão do Fogaréu, que inicialmente aconteceu em 1976 onde somente três pessoas participaram. Daí em diante, esse número foi aumentando e hoje a procissão conta com 40 farricocos (homens encapuzados), e milhares de pessoas 
acompanhando, sempre na quarta-feira de cinzas com início às 24:00 na porta do Museu de Arte Sacra da Boa Morte, simbolizando assim, a busca e a prisão de Jesus em Jerusalém.

Além da Procissão do Fogaréu, vale destacar a Festa do Divino Espírito Santo e mais recentemente a criação do Festival Internacional de Cinema e Vídeo Ambiental. Pode-se revelar ainda a saída de blocos tradicionais como o Zé-Pereira nos dias de carnaval e a Festa de Nossa Senhora do Rosário com a realização de quermesses.

\section{Na música}

Além das famosas serestas de Goiás e da música caipira de raiz, a cidade ainda conta com músicas tradicionais como aquelas cantigas de catira (dança típica) e um legado de música sacra e barroca.

\section{No ambiente natural}

Além da potencialidade da Serra Dourada, que é objeto de estudo deste trabalho, outras áreas naturais também fazem parte do roteiro de muitos turistas na Cidade de Goiás, como por exemplo, a Cachoeira da Andorinha, distante cerca de 30 minutos do centro, no córrego Zanzan. No Balneário Santo Antônio, distante 9 km da cidade, também se pode tomar banho no rio.

Outra pedida para os turistas é percorrer a Trilha Imperial, antiga estrada que ligava Villa Boa aos vilarejos de Ouro Fino e Ferreiro, e por onde passavam as tropas de mula levando o ouro de Goiás, incluindo banho na bica do carreiro e no próprio Rio Vermelho. Existe também uma boa quantidade de hotéis-fazenda no entorno do município, o que propicia a prática do turismo em um ambiente natural.

Enfim, hoje a Cidade de Goiás conta com uma boa infra-estrutura de apoio ao turismo com hotéis, pousadas, restaurantes, bares, lojas de artesanato, guias locais, entre outros mais. A cidade disponibiliza ainda, de uma infra-estrutura básica, como serviços de mecânica, transporte (rodoviária), táxi e moto táxi, polícia, farmácias, hospitais, postos de combustível, bancos, serviço de correios, e outros que facilitam a vida do turista.

O fato da Cidade de Goiás ter todos os requisitos necessários para receber o turista, sem dúvida nenhuma, favorece ainda mais a implantação do ecoturismo no Parque Estadual 
da Serra Dourada, até porque, os turistas que já visitam a cidade terão uma opção a mais de lazer e conseqüentemente, já terão toda uma infra-estrutura de apoio durante sua visitação.

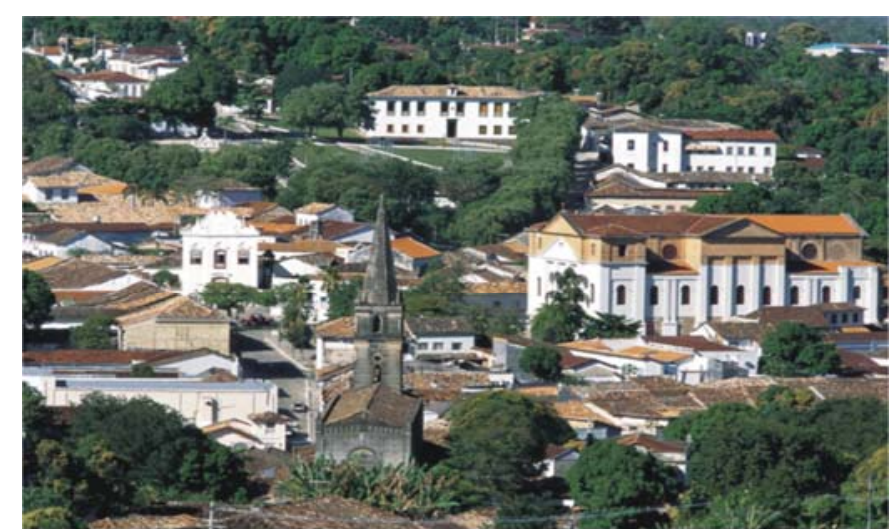

Foto 13: Lázaro Tuim

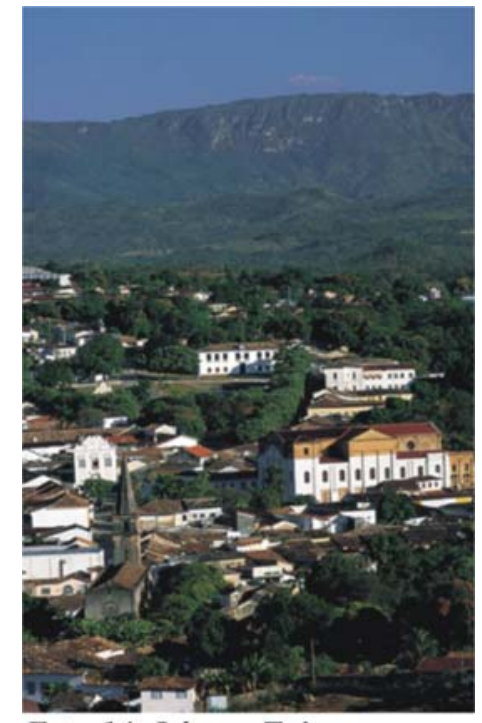

Foto 14: Lázaro Tuim 


\section{CAPÍTULO 4}

\section{QUESTÕES AMBIENTAIS NO BRASIL E NO MUNDO}

\section{1 - A Devastação do Meio Ambiente}

No presente capítulo, exponho questões relativas ao meio ambiente no Brasil e no mundo, pois com esta iniciativa, tenho a intenção de mostrar um cenário mais amplo, para em seguida, nele inserir meu objeto de estudo, ou seja, é uma maneira de estar relacionando o próprio desenvolvimento do ecoturismo em unidades de conservação, dentro desse panorama de dimensões vastas, que é a problemática ambiental.

Não poucos estudiosos lembram que o meio ambiente é formado pelos elementos produzidos pela própria natureza, a chamada primeira natureza (solo, vegetação, rios, relevo, clima, entre outros), e pelos elementos produzidos pelo homem, ou seja, a segunda natureza (habitações, fábricas, campos cultivados, entre outros). De todos os seres vivos, o ser humano é o único que, além de fazer parte do ambiente natural, participa também do ambiente artificial, que é produto da interferência e do desenvolvimento tecnológico do próprio homem.

É impossível prever se o homem conseguirá um dia tornar-se totalmente independente do meio natural, ou se antes disso já terá destruído a natureza e a si próprio, mas o importante é que já vivemos atualmente uma época de preocupações ecológicas, isto porque, estamos diante de um quadro de degradação ambiental tão grande que já existe ameaça para a própria 
continuidade da vida em nosso planeta. Ao longo de sua história evolutiva, o homem tem sido o maior responsável pela destruição da natureza, mas nunca havíamos chegado no nível em que nos encontramos.

A poluição, os desmatamentos, a exploração irracional de recursos naturais, a degradação dos solos agriculturáveis e outras agressões, atingiu no último século níveis inadmissíveis. Referindo-se particularmente ao Brasil, que ainda possui uma das maiores áreas naturais intactas em todo o mundo, nem por isso, a devastação aqui é menor, pelo contrário, a cada dia tem aumentado esses índices, que se mostram alarmantes.

“O aumento populacional, aliado à má distribuição de renda, ao escoamento de alimentos dos povos pobres para os ricos e ao extremo consumismo dos países desenvolvidos, tem transformado o homem numa ameaça aos demais seres do planeta, pois, para garantir nossa sobrevivência, estamos dizimando toda a biosfera” (Neiman, 1989, p. 3).

Apesar do crescimento populacional ser um dos principais responsáveis pela devastação ambiental, este não é o único fator, pois a própria necessidade crescente de produção de alimentos e de obtenção de matéria-prima para as indústrias, pode provocar em curto espaço de tempo, o colapso total dos sistemas biológicos.

Além disso, a própria necessidade de deslocamento do homem, com a construção de mais estradas é um fator agravante, isto porque, a aceleração desse desenvolvimento industrial, a partir principalmente da segunda metade do século XIX, com a Revolução Industrial e o próprio desenvolvimento do capitalismo, foi responsável pela crescente necessidade de exploração dos recursos naturais.

Um dado importante a se destacar, é que os países mais desenvolvidos, pagando o preço de seu progresso, logo esgotaram suas fontes energéticas e minerais, onde florestas inteiras foram queimadas. Uma vez devastados os seus territórios, esses países voltaram-se para a exploração das riquezas do Terceiro Mundo, hoje chamados de países em desenvolvimento.

As florestas tropicais do mundo começaram a ser destruídas na década de 1940, principalmente na Ásia, e hoje, devido ao seu potencial madeireiro, a América Latina tem 
sido, o alvo principal. O Brasil tem-se tornado o centro das atenções internacionais, pois são milhares os focos de devastação em todo o país, como por exemplo, os impactos ecológicos nos manguezais, a ocupação irracional da Amazônia, a destruição de dunas em nosso litoral, a poluição de pólos petroquímicos, as ameaças ao Pantanal, a extinção quase que completa da Mata Atlântica, os incêndios constantes no cerrado, e incontáveis outras agressões.

A questão de degradação do meio ambiente é eminentemente política e econômica, pois envolve diretamente as relações dos países desenvolvidos e em desenvolvimento, isto é, países ricos e pobres. Constata-se, que o modelo sócio-econômico e político de nossa civilização contribuem de maneira fundamental para o uso irracional dos recursos naturais, mesmo ainda, particularmente acreditando, que é perfeitamente possível conciliar desenvolvimento com preservação do meio ambiente.

Apesar de todos esses problemas mencionados, o quadro parece estar finalmente se alterando, ou seja, a devastação chegou a tal ponto que não consegue mais passar despercebida. Por isso mesmo, ao longo dos últimos anos, diversas associações de defesa da natureza foram criadas a fim de divulgar o pensamento ecológico, sendo assim, qualquer cidadão hoje em dia está razoavelmente informado e ciente destes problemas. De acordo com Neiman "ao contrário da defesa apaixonada da mãe natureza, os ecologistas atuais atacam com argumentos consistentes” (1989, p.6).

O apoio da comunidade científica foi fundamental nessa conquista, bem como, a imprensa, que também tem desempenhado um papel fundamental, uma vez que torna públicos todos os problemas ambientais, alertando a todos sobre seus efeitos. Na abordagem atual, privilegia-se a idéia de conciliar o desenvolvimento com a preservação ecológica e com a melhoria da qualidade de vida do ser humano, e foi exatamente dentro desse contexto que surgiu então a idéia da sustentabilidade, tão amplamente difundida nos dias de hoje, nascendo, portanto, um novo paradigma do desenvolvimento.

Apesar do avanço conseguido, nossos ecossistemas continuam sendo agredidos, por isso, muito ainda há que se fazer, pois cada um de nós pode desempenhar um papel importante na luta pela preservação de toda exuberância que a natureza levou milhões de anos para construir. Essa nossa contribuição pode vir até mesmo através do incentivo ao 
ecoturismo, que pode ser uma alternativa de utilização racional dos recursos naturais, desempenhando assim uma função ímpar de combate à descaracterização do meio ambiente.

Em decorrência disso, no próximo tópico deste capítulo será abordada a importância da criação de leis, bem como, de órgãos governamentais, para também tentar evitar a exploração dessas áreas naturais.

\section{2 - As Conferências sobre Meio Ambiente e a Legislação Ambiental}

A preocupação com a questão ambiental tal como se apresenta hoje é um fato muito recente na história da humanidade, ou seja, esse tipo de consciência teve início na década de 1970, principalmente em meio aos debates promovidos pela Organização das Nações Unidas (ONU).

Dentre essas primeiras discussões, vale destacar a Conferência de Estocolmo no ano de 1972, em que a percepção global das reais conseqüências da utilização da energia nuclear, dos grandes desmatamentos e da queima de combustíveis, começou a preocupar a opinião pública e os governantes. A partir dessa reunião, a questão social, como resultado de desenvolvimento econômico, passa a ser eixo dos debates ambientais, em que a pobreza é encarada como raiz dessa problemática. Surge assim, a tese conservacionista que difunde idéias de um ecodesenvolvimento.

Foi ainda nesse mesmo ano, que em Paris, a Organização das Nações Unidas para a Ciência e Cultura (UNESCO) criou um tratado internacional denominado “Convenção sobre a Proteção do Patrimônio Mundial Cultural e Natural”, para incentivar a preservação de bens culturais e naturais considerados significativo para a humanidade, questão esta, já tratada no capítulo anterior.

Já na década de 1980, mais precisamente no ano de 1988, surge o Relatório Brundtland da ONU, que introduz o conceito de desenvolvimento sustentável, ou seja, satisfazer as necessidades do presente sem comprometer as possibilidades de as gerações futuras satisfazerem as suas próprias. O relatório prioriza também a satisfação das necessidades das camadas mais pobres da população, bem como, define como condições 
básicas para o desenvolvimento a própria conservação dos ecossistemas e questiona os limites que o estado atual da tecnologia e organização social impõem ao meio ambiente.

No ano de 1992, na cidade do Rio de Janeiro, acontece a Conferência Mundial do Meio Ambiente e Desenvolvimento - ECO 92, que cria a Agenda 21, um documento assinado pelos 200 países que aí estiveram. Segundo Montoro "esse documento é formado por 40 capítulos com metas para mudar o desenvolvimento injusto e destrutivo do planeta, buscando práticas sustentáveis e modalidades de cooperação internacional de combate à pobreza, questionando os padrões de consumo, especialmente, colocando a necessidade de informação aberta para que todos possam participar de decisões e ações que afetam a vida no planeta” (2003, p. 18).

A Agenda 21, hoje é considerado o documento de maior abrangência e maior alcance com relação à questão ambiental, sendo também a proposta mais consistente que existe de como alcançar o desenvolvimento sustentável, isto é, de como podemos continuar desenvolvendo nossos países e nossas comunidades sem destruir o meio ambiente e com maior justiça social. É considerado ainda um roteiro de ações concretas, com metas, recursos e responsabilidades definidas, bem como, um planejamento do futuro com ações de curto, médio e longo prazos, pois reintroduz uma idéia até então esquecida, a de que podemos e devemos planejar e estabelecer um elo de solidariedade entre nós e nossos descendentes.

Enfim, é um programa estratégico e universal, obtido através de consenso e que estabelece uma parceria entre os governos e a sociedade, a fim de alcançarmos o desenvolvimento sustentável.

A Agenda 21 Global, favoreceu logo em seguida, a iniciativa de se criar uma Agenda 21 Brasileira. Esta é considerada um processo de planejamento estratégico participativo, que está sendo conduzido pela Comissão de Políticas de Desenvolvimento Sustentável da Agenda 21 Nacional - CPDS. A metodologia de elaboração da Agenda privilegiou uma abordagem multissetorial da realidade brasileira, procurando focalizar a interdependência das dimensões ambiental, econômica, social e institucional. Além disso, determinou que o processo de elaboração e implementação deve estabelecer parcerias, entendendo que a Agenda 21 não é um documento de governo, mas um produto de consenso entre os diversos setores da sociedade brasileira. 
Definiu-se que a Agenda 21 Brasileira seja estruturada em três grandes partes: uma introdução, onde se pretende traçar um panorama do país no limiar do século 21; uma parte consagrada a seis temas estabelecidos como prioritários (cidades sustentáveis, agricultura sustentável, infra-estrutura e integração regional, gestão dos recursos naturais, redução das desigualdades sociais, ciência e tecnologia e desenvolvimento sustentável); e uma parte final sobre os meios de implementação das estratégias estabelecidas para cada tema.

Foi definido também, que as proposições que a Agenda vier a apontar como políticas públicas brasileiras se constitua na base da elaboração dos Planos Plurianuais do governo (PPA), obrigação constitucional brasileira de a cada quatros anos aprovar no Congresso Nacional, os programas nos quais serão aplicados os recursos públicos do país. Assim, cada estado brasileiro terá suas diretrizes e ações inseridas dentro das vertentes do documento “Agenda 21 Brasileira - Bases para a Discussão”, que foi lançado em 2002.

Dois documentos compõem a Agenda 21 Brasileira: “Agenda 21 Brasileira - Ações Prioritárias”, que estabelece os caminhos preferenciais da construção da sustentabilidade brasileira, e “Agenda 21 Brasileira - Resultado da Consulta Nacional”, produto das discussões realizadas em todo o território nacional.

A Agenda 21 serve de guia para as ações do governo e de todas as comunidades que procuram desenvolvimento sem com isso destruir o meio ambiente. Da mesma forma que os países se reuniram e fizeram a Agenda 21, as cidades, os bairros, os clubes, as escolas também podem fazer a Agenda 21 Local.

É bom lembrar ainda, que quando se elaborou a Agenda 21, pouco destaque foi dado aos impactos ambientais e sociais do turismo. Assim, desde 1992, as preocupações internacionais sobre a sustentabilidade do turismo vêm aumentando constantemente e por isso mesmo, os países endossaram declarações sobre uma vasta gama de temas afins, inclusive o turismo e desenvolvimento sustentável, o impacto social do turismo, o turismo e a biodiversidade e o turismo e a ética.

Dessa maneira, em 1996, a Organização Mundial do Turismo, o Conselho Mundial de Viagens e Turismo e o Conselho da Terra divulgaram um plano de ação, a Agenda 21 para a Indústria de Viagens e Turismo. Essas discussões internacionais sobre os impactos do turismo 
adquiriram um ímpeto maior ainda em 2002, no momento em que começa a se desenvolver o “Ano Internacional do Ecoturismo”, declarado pela ONU, que teve um encontro em Quebec no Canadá.

Já no ano de 2002, a cidade de Joaenesburgo na África do Sul, sediou a II Conferência Mundial para o Desenvolvimento Sustentável, popularmente conhecida como "Rio + 10", que avaliou a implantação da Agenda 21. Conforme Montoro “as metas da Conferência, em grandes linhas, podem ser agrupadas em três vertentes, ou seja, identificar os resultados após 10 anos, tomar decisões para ação e renovar compromissos e estratégias de governança” (2003, p. 19).

Enfim, preocupações de parte das elites mundiais como essas mencionadas, terminaram por estimular o surgimento, também em nosso país, de um discurso ambiental em nível governamental e conseqüentemente dando aberturas para a criação do Direito Ambiental Brasileiro. Assim, é importante se destacar a evolução da legislação ambiental no Brasil, apontando os avanços que já conquistamos em relação à consolidação dos instrumentos jurídicos que possam levar a sustentabilidade.

No Brasil Colônia, por exemplo, quase inexistia leis que versassem sobre a questão ambiental, mesmo assim, de acordo com Martins; Soler e Soares "em 1605 foi editado o Regimento sobre o pau-brasil, no qual estava estabelecido que o corte efetuado sem a devida anuência real sujeitava os autores a diversas penalidades” (2001, p. 168). É claro que isso não evitou sua arrasadora exploração, mas foi um primeiro alerta. Já no Estado Novo, foi regulamentado o uso das águas e estabelecido o primeiro Código Florestal Brasileiro.

A partir dos anos 70, veio a se constituir as políticas ambientais, sendo que, em 1973 houve a criação da Secretaria Especial de Meio Ambiente (SEMA) e em 1979, houve a criação de lei que definiu os princípios gerais para o parcelamento do solo urbano. Vale ressaltar que a Sema foi criada em pleno regime ditatorial, com traços fortemente burocráticos e sem nenhuma articulação com a sociedade. Fraco já em seus primeiros momentos, este órgão ambiental do governo federal fortaleceu-se com a Lei 6.938/1981, que definiu os marcos e os instrumentos da política nacional de meio ambiente. Gradualmente, se constituiu um Sistema Nacional de Meio Ambiente (SISNAMA), e também o Conselho Nacional de Meio Ambiente (CONAMA). 
Em 1988, a Constituição Federal passou a exigir a execução de Plano Diretor para cidades com mais de 20 mil habitantes, assim como, nesse mesmo ano, se estabeleceu a implementação dos programas de zoneamento e elaboração dos planos de gestão e monitoramento.

Em 1989, foi criado o Instituto Brasileiro de Meio Ambiente e Recursos Naturais Renováveis (IBAMA), órgão executor da política de meio ambiente, tendo a intenção de associar a proteção ambiental ao uso conservacionista de alguns recursos naturais. Hoje, o Ibama está subordinado ao Ministério do Meio Ambiente, este criado em 1992.

Diversas outras leis foram sendo promulgadas ao longo dos anos, como por exemplo, a Lei 9.433/1997, criando a Política Nacional de Recursos Hídricos, a Lei 9.795/2000 que cria a Política Nacional de Educação Ambiental, a Lei 9.985/2000, que instituiu o Sistema Nacional de Unidades de Conservação da Natureza (SNUC), entre tantas outras. Por isso, há de se constatar que é notória a importância da criação de órgãos e leis ambientais no Brasil, uma vez que a construção de estratégias de desenvolvimento sustentável, necessita contar com instrumentos jurídicos eficientes e eficazes, com vistas ao manejo adequado dos ecossistemas.

Desse modo, pode-se verificar que com o movimento ambiental ganhando forma e conteúdo pelo mundo, a produção de leis com temas socioambientais foi uma questão de tempo. É, portanto, dentro desse panorama, que particularmente na segunda metade da década de 80, a questão ambiental brasileira é fomentada, pela criação de secretarias estaduais do meio ambiente, pela presença de sindicatos, por grupos científicos e por empresas que buscam uma gestão ambiental.

Segundo Martins; Soler e Soares "as leis ambientais brasileiras, de certa forma, guardam um perfil mais punitivo do que preventivo, e a prevenção é fundamental para a sustentabilidade, pois a punição do degradador, prevista em lei e eventualmente aplicada, não evita o dano ambiental" (2001, p.176).

É bom deixar claro, que muitos desafios ainda devem ser transpostos na luta para fazer a questão ambiental penetrar a consciência da própria sociedade civil, em que o meio ambiente passe a ser visto como base para as melhores condições de vida e trabalho das populações, construindo a cidadania para o desenvolvimento. Isto porque, mesmo sabendo 
que as leis ambientais brasileiras são das mais consistentes do mundo, os órgãos ambientais no Brasil foram se caracterizando por acentuada descontinuidade administrativa. Além disso, esses instrumentos jurídicos devem prescindir de aperfeiçoamentos constantes.

Como diz Santilli, J. e Santilli, M. "apesar dos entraves ainda existentes, democracia e meio ambiente não se juntam apenas episodicamente, nem se resumem a uma questão de formalidade no cumprimento das leis, mas constituem uma aliança política e simbólica intrínseca aos projetos de futuro para o Brasil”" (2002, p. 53).

Afinal de contas, para que seja possível a aplicação da justiça ambiental é importante o conhecimento das pessoas sobre seus direitos, pois isso, consolidará instrumentos para a gestão de um ambiente ecologicamente equilibrado, inclusive garantido pela Constituição Federal, como bem de uso comum do povo. Essa justiça social será alcançada também, quando se recuperar e estruturar efetivamente o poder público nos três níveis de governo (federal, estadual e municipal). Assim, o próximo item desse capítulo, trata justamente do fato de que, um ambiente ecologicamente equilibrado poderá ser alcançado quando áreas de grande sensibilidade estiverem protegidas por lei, como é o caso das unidades de conservação.

\section{3 - O Surgimento das Unidades de Conservação (UCs) e do Sistema Nacional de Unidades de Conservação (SNUC)}

Foi nos Estados Unidos no final do século XIX, que surgiu a primeira área natural protegida, o Parque Nacional de Yellowstone, devido à luta de exploradores do rio Yellowstone pela preservação das belezas naturais. Esse é considerado o ponto de origem para a conceituação de áreas protegidas e para a concepção de parque nacional, embora, muitas pessoas acreditam que iniciativas semelhantes já tivessem ocorrido em outros lugares do mundo, como por exemplo, as reservas de caça da realeza européia.

O Parque Nacional de Yosemite, também merece destaque, visto que, no ano de 1864, o então presidente dos Estados Unidos, Abraham Lincoln, uniu-se aos movimentos de proteção à natureza que lutavam contra a crescente expansão industrial, decretando a criação desse parque, que era muito conhecido na época pelas enormes sequóias. 
Diversos países não tardaram a adotar a prática de criação de parques visando à conservação de suas áreas naturais. São pioneiros também, o Parque Nacional Royal na Austrália, o Parque Nacional Banff no Canadá, o Parque Nacional Egmont na Nova Zelândia, o Parque Nacional Kruger na África do Sul, entre outros.

A idéia de parque foi tendo sucesso com o tempo. No início, o crescimento foi lento, apresentando um aumento durante os anos 20 e 30, antes de ficar estacionado por volta da II Guerra Mundial. A partir do início dos anos 50, o incremento tomou impulso, tendo sido criado entre 1970 e 1980 o dobro de áreas que existiam até 1960.

"Na América do Sul, as primeiras áreas protegidas foram criadas por iniciativa de um pequeno número de pessoas devotas à conservação, como por exemplo, Francisco P. Moreno, na Argentina, e Henri Pitter, na Venezuela” (Morsello, 2001, p. 24).

No Brasil, a primeira unidade de conservação (UC) criada, foi o Parque Nacional de Itatiaia no Rio de Janeiro no ano de 1937, apesar de que, desde o Brasil Colônia preservaramse áreas naturais como os hortos e jardins botânicos, criados a partir da instalação da família real portuguesa. Também em fins do século XIX, durante o Império, já havia sido proposto a criação de parques em outras regiões que não esse no Rio de Janeiro. De qualquer forma, após o Parque Nacional de Itatiaia, outros foram sendo criados, por exemplo, o Parque Nacional de Iguaçu no Paraná e o Parque Nacional da Serra dos Órgãos no Rio de Janeiro.

Após um longo intervalo de tempo, diversos outros parques foram criados no Brasil, dentre eles, o Parque Nacional de Aparados da Serra (RS/SC), o Parque Nacional do Araguaia (GO/TO), o Parque Nacional de Ubajara (CE), o Parque Nacional das Emas e Chapada dos Veadeiros (GO), Parque Nacional de Caparaó (MG/ES), entre tantos outros. Até esse momento, o principal objetivo que norteou a criação dessas unidades de conservação era propiciar o acesso a locais de grande beleza para as populações e já incorporando bem timidamente o objetivo de conservação biológica.

Pouco a pouco, o usufruto de belezas cênicas deixa de ser objetivo principal, tomando seu lugar a conservação da natureza, isso porque, em consonância com a Fundação Prónatureza (FUNATURA) “o reboque da conquista do Centro-Oeste brasileiro, aumentou a 
degradação de formações como o cerrado e o pantanal” (apud Morsello, 2001, p. 154). Contudo, hoje em dia, a recreação, a beleza cênica, a pesquisa e a educação, continuam a influenciar o processo de implantação de UCs, possibilitando com isso, a realização do turismo nesse mesmos locais.

“Em 1967 foi criado o Instituto Brasileiro de Desenvolvimento Florestal, o IBDF, organismo ligado ao Ministério da Agricultura - e que por muito tempo foi o grande mentor das Unidades de Conservação federais no país” (Costa, 2002, p. 20). Hoje, as unidades podem ser vinculadas a diferentes órgãos administrativos, de acordo com sua natureza, seu objetivo e seu estatuto, apesar de a grande maioria encontrar-se sob a administração do Ibama ou outros órgãos estaduais e municipais competentes na área ambiental.

É bom ressaltar, que as unidades de conservação podem ser criadas em nível federal, estadual (como é o caso do Parque Estadual da Serra Dourada) e em nível municipal, seja por meio de decreto ou lei, sendo que, embora a criação ocorra oficialmente mediante diploma legal, sua existência se dá de fato, apenas após a adoção de medidas concretas, ou seja, que efetivem sua criação, tais como a demarcação do terreno, a instalação de infra-estrutura, a colocação de recursos humanos, entre outros.

Com a ampliação dos parques nacionais em todo o mundo, o título de parque, passou a ter uma variedade enorme de significados, e a inconsistência nos termos levou a iniciativas de unificação tanto dos conceitos como de práticas, vindo a ocorrer várias convenções com esse propósito.

Com o objetivo de cooperação nessa área, foi criada em 1948 a União Internacional para a Proteção da Natureza, que após algumas transformações, originou a União Internacional para a Conservação da Natureza (IUCN), que entre outras linhas, tinha a responsabilidade de inventariar todas as áreas protegidas do mundo. Em 1962, a IUCN realiza em Seatle (EUA) a primeira Conferência Mundial de Parques Nacionais, discutindo-se os critérios de classificação de áreas protegidas, e desde então, a IUCN faz recomendações sobre as diferentes terminologias utilizadas e quais os diferentes tipos de unidades de conservação.

Conforme Mcneely (apud Morsello, 2001, p. 21) "por muito tempo, as unidades públicas, e dentre estas os parques nacionais, foram o centro da política de conservação mundial”. Hoje, já se 
observa um movimento crescente de ampliação de iniciativas para a instituição de reservas particulares, tendência bastante seguida também no Brasil. De uma certa forma, as unidades de conservação públicas são criadas para compensar usos indevidos nas áreas particulares, por isso, as reservas particulares podem auxiliar a conservação.

Sendo assim, com o tempo, o conceito de parque nacional foi sendo transformado dando origem a diferentes tipos de UCs. A própria IUCN desenvolveu então, uma classificação de UCs, e exatamente tendo por base essa classificação que foi criado no Brasil, o Sistema Nacional de Unidades de Conservação (SNUC).

O Sistema Nacional de Unidades de Conservação foi a primeira normatização nacional das áreas naturais protegidas por leis, tendo sido aprovado em 2000 através da Lei 9.985. Consoante com o SNUC, em seu artigo $2^{\circ}$ a unidade de conservação é "espaço territorial e seus recursos ambientais, incluindo as águas jurisdicionais com características naturais relevantes, legalmente instituído pelo PODER Público, com objetivos de conservação e limites definidos, sob regime especial de administração, ao qual se aplicam garantias adequadas de proteção".

Além de contribuir para a manutenção da diversidade biológica, de contribuir para a preservação da diversidade de ecossistemas, de promover o desenvolvimento sustentável, de proteger e recuperar os recursos hídricos, de proporcionar meios e incentivos para pesquisa, entre outros, um dos mais importantes objetivos do SNUC, é o de impor os critérios que devem regular as categorias de manejo, deixando claro os objetivos e a denominação a ser utilizada.

As unidades de conservação integrantes do SNUC dividem-se em Unidades de Proteção Integral e Unidades de Uso Sustentável. A primeira, composta pelas categorias de Estação Ecológica, Reserva Biológica, Parque Nacional, Monumento Natural e Refúgio de Vida Silvestre, enquanto o grupo de Uso Sustentável compõe-se pelas categorias de Área de Proteção Ambiental, Área de Relevante Interesse Ecológico, Floresta Nacional, Reserva Extrativista, Reserva da Fauna, Reserva de Desenvolvimento Sustentável e Reserva Particular do Patrimônio Natural.

Os parques são os principais elementos de unidades de conservação existentes, pois foi por meio deles, como já mencionado anteriormente, que surgiram as demais categorias, dessa 
forma, eles representam um grande atrativo turístico para o país e são responsáveis em grande parte, pelo marketing do segmento de ecoturismo. Por isso mesmo, essa monografia lança um olhar sobre a viabilidade de implantação do ecoturismo no Parque Estadual da Serra Dourada, que é uma de suas vertentes, porém com administração pública em âmbito estadual.

\section{4 - A Prática do Ecoturismo em Unidades de Conservação}

A criação de parques nacionais e demais áreas naturais protegidas, tem sido, um dos principais elementos de estratégia para a conservação da natureza, mas, desde seu início, essas áreas também foram estabelecidas para fornecer às populações urbanas meios de lazer e contemplação. Assim, a concepção dessas áreas protegidas nos remete a idéia de que, mesmo se a biosfera fosse totalmente transformada pelo homem, poderia haver espaços do mundo natural em seu estado primitivo sem a interferência humana.

Com a difusão da idéia de desenvolvimento sustentável, que repercutiu de várias maneiras entre os diversos agentes interessados em crescimento econômico no mundo, o turismo, e mais precisamente o ecoturismo nessas áreas, se apresentam como atividades econômicas visivelmente influenciadas pela tentativa de elaboração de novos parâmetros, estes sendo, ecologicamente viáveis e socialmente justos. O ecoturismo surge então como uma nova forma de "exploração" da natureza, exploração esta, dentro de um contexto econômico e não destrutivo.

A própria diversidade da fauna e da flora vem despertando cada vez mais o interesse das pessoas para esses ambientes naturais, bem como, o estresse da vida moderna têm gerado demanda cada vez mais crescente por essas atividades, sendo que, as UCs representam talvez os espaços mais significativos e importantes. É dessa maneira, que aos poucos, o governo começa a perceber o grande filão do turismo na natureza.

Desse modo, é bom ressaltar que a implantação de parques, reservas e outras categorias de manejo pode então funcionar como garantia estratégica de conservação da natureza em países periféricos, caracterizados por elevada biodiversidade, como é o caso do Brasil, e, além disso, também podendo representar uma importante fonte de renda e ingresso 
de divisas, considerando seu potencial como contribuição ao Produto Interno Bruto, a exemplo do que já ocorre em alguns países da América Latina.

Para Irving “ $a$ utilização de áreas protegidas para o ecoturismo reflete, portanto, algumas tendências globais, entre as quais, o crescimento da consciência ambiental, em razão dos níveis crescentes de degradação da base dos recursos naturais, incluindo a destruição dos ecossistemas de alta relevância para a preservação da biodiversidade global, e o processo de reencontro do homem com sua própria essência, abandonada pela sociedade de consumo, e profundamente afetada pelo fenômeno de globalização” (2002, p. 48).

Apesar de ser bastante vantajoso para o Brasil em se investir no ecoturismo em unidades de conservação, o seu planejamento e sua gestão representam, nos dias atuais, um dos maiores desafios que o país enfrenta, com o objetivo de estar compatibilizando os pressupostos de conservação ambiental, em áreas de elevado valor patrimonial em biodiversidade, com a operacionalização do conceito de desenvolvimento sustentável.

Um fato já detectado nesses últimos anos, é que apesar da lei 9.985/2000 estabelecer que os recursos obtidos com a utilização de áreas naturais protegidas deverão ser revertidos para a conservação da própria unidade e demais UCs do país, essa ainda não é a prática adotada, e estudos realizados já ilustram a tendência global de exclusão das populações locais, com relação aos benefícios trazidos pela atividade.

Esses espaços protegidos representam, sob meu ponto de vista, a relação homemnatureza, e dessa forma, não devem ser vistos apenas como natureza intocada, mas pelo contrário, devem se constituir em lugares desejados e procurados pelo homem para visitação. Por isso, considerando importante essa relação, acredito que as áreas naturais que permitem a entrada de turistas e excluem as populações tradicionais são inconcebíveis, ou seja, é negar a presença de moradores que vivem na área há muitas gerações e que, pelo seu modo de vida, são em grande parte responsáveis pela própria conservação dessas áreas.

Sendo assim, no processo de implantação do ecoturismo em unidades de conservação, todos esses aspectos devem ser levados em consideração, e para tanto, é necessário estar verificando de fato, a real necessidade de exclusão das comunidades, tradicionais ou não. $\mathrm{Na}$ realidade, um dos principais obstáculos para a utilização de parques para o ecoturismo talvez 
esteja ligado justamente à questão fundiária e todas as suas implicações. Como as UCs, em sua grande maioria, têm sido estabelecidas com base apenas em dados técnicos, e não por consultas às comunidades locais e aos segmentos vinculados, muitas dessas áreas ficam só no papel, uma vez que, a maior parte delas não tem sua situação fundiária regularizada e suas comunidades, que se utilizam da base de recursos naturais para a sua sobrevivência ainda não detêm o direito legal sobre a terra.

De acordo com Serrano, "no (cap. II, art. $4^{\circ}$ ) do SNUC, está estabelecido que dentre os seus objetivos, está o de favorecer condições e promover a educação ambiental e a recreação em contato com a natureza" (1997, p. 108). Esse parágrafo, embora não toque diretamente na atividade de turismo, abre possibilidades para o seu desenvolvimento em unidades de conservação, constatando-se, portanto, a viabilidade de implantação do ecoturismo nesses ambientes naturais.

“Um problema freqüente, observado em planejamento ecoturístico, diz respeito à homogeneização do conceito de unidades de conservação, o que pode resultar em problemas de difícil solução e gerenciamento. É importante que esteja clara a distinção com relação às tipologias de unidades de conservação e suas potencialidades e/ou restrições para o ecoturismo, principalmente em relação ao que o SNUC denomina de uso sustentável e proteção integral (Irving, 2002, p. 55).

Por isso mesmo, vale salientar, que entre as categorias de unidades de conservação, as únicas em que são permitidas as visitações são os parques, os monumentos naturais, os refúgios de vida silvestre, as áreas de proteção ambiental e as Reservas Particulares do Patrimônio Natural (RPPNs). Essas Reservas Particulares do Patrimônio Natural e as Áreas de Proteção Ambiental (APA) são juntamente com os Parques, as categorias de UCs mais importantes para o incremento do turismo, em seu segmento ecoturismo. No caso das RPPNs, que são particulares, o desenvolvimento turístico nessas áreas requer interesses privados.

De um ponto de vista ideal, o desenvolvimento do ecoturismo nessas áreas, quaisquer que sejam as categorias, pode gerar vários benefícios, como por exemplo, a possibilidade de integração das UCs com as comunidades locais, a circulação de informação ambiental por meio de programas educativos, o aumento da oferta regional de espaços de recreação e lazer, a geração de emprego e renda, entre outros aspectos. 
Entretanto, é bom lembrar sempre, que essa atividade também não deixa de provocar impactos negativos, como por exemplo, o pisoteamento, compactação e erosão na abertura de atalhos em trilhas; a depredação da infra-estrutura; a deposição inadequada de lixo que pode interferir na alimentação dos animais e poluir os cursos d’água e o barulho, excesso de cores e odores que podem também perturbar o ambiente sonoro, visual e olfativo da fauna.

Por isso mesmo, é necessário que o ecoturismo nesses ambientes se desenvolva por meio de um planejamento adequado, utilizando-se instrumentos de zoneamento, bem como, de estudo de capacidade de carga que devem ser previstos nos seus planos de manejo. Conforme Cifuente (Apud Serrano, 1997, p. 112) “a capacidade de carga turística poderia ser definida como o nível de visitação que um sítio pode suportar, sem causar a deterioração aos recursos e ao ambiente social do lugar, e sem que se diminua a qualidade da experiência dos visitantes".

Apesar de todo o processo de amadurecimento do SNUC, tais medidas ainda têm muita dificuldade em sair do papel, em encontrar sua efetivação. “Dados do Ibama de 1994 apontam para o fato de que, dos 35 parques nacionais existentes, apenas 18 encontravam-se abertos à visitação, e precariamente” (Serrano, 1997, p. 110). Essa precariedade é reflexo de pouca infraestrutura e de pouco pessoal qualificado, dessa maneira, a infra-estrutura mínima é condição essencial para o atendimento às necessidades de demanda turística, porém, a satisfação desse item engloba também a necessidade de um planejamento com mínimo impacto ambiental e total integração entre grupos sociais envolvidos.

A carência de informações sobre as áreas naturais protegidas, e à qualificação de pessoal para a transmissão desse conhecimento aos ecoturistas, nos mostra a necessidade sem precedentes, de pessoal qualificado, bem como, o que diz respeito à infra-estrutura deficitária disponível e em condições precárias que carece de melhorias imediatas.

Assim sendo, verifica-se que o desenvolvimento do ecoturismo em UCs, exige uma série de necessidades que devem ser satisfeitas para que se possa garantir um funcionamento eficaz da atividade, evitando com isso o uso incorreto e indesejável dos espaços naturais.

Para tanto, poderá ser realizada a construção e implantação de um centro de visitantes, a criação de estrutura administrativa no local, a contratação e treinamento de pessoal, a 
definição física e o zoneamento detalhado das potencialidades da área, a abertura ou melhoria nas condições físicas das trilhas de visitação, o desenvolvimento de um amplo programa de comunicação, a implantação de um sistema de sinalização, o cadastramento das potencialidades turísticas do entorno, a criação de material promocional, a promoção de estudos e pesquisas, como por exemplo, Estudos de Impacto Ambiental (EIA) e seus relatórios (RIMA), programas de educação ambiental para os turistas e comunidades receptoras, a intensificação da fiscalização e outros mais.

Mesmo se constatando esses problemas, muito dificilmente os órgãos governamentais atuam em conjunto para tentar minimiza-los, o que acaba gerando freqüentes conflitos e uma atuação institucional distante da realidade local. Adicionalmente, também não existe um mecanismo sistemático de integração entre os órgãos federais, estaduais e municipais com atribuição na gestão de unidades de conservação, o que acaba por produzir ações segmentadas e pouco efetivas com relação à conservação de áreas de elevada biodiversidade.

Por isso mesmo, em consonância com Irving "há também que considerar a questão institucional, pois apenas recentemente os órgãos de meio ambiente passaram a trabalhar em conjunto com as instituições responsáveis pelo planejamento turístico e a resultante dessa sinergia foi o documento Diretrizes para uma Política Nacional de Ecoturismo, elaborado conjuntamente pela Embratur e pelo Ibama em 1994” (Irving, 2002, p. 60).

Logo, um fator que pode contribuir para o desenvolvimento do ecoturismo em UCs, é a própria Política Nacional de Ecoturismo, que volta-se para a necessidade de um planejamento integrado e para a articulação em vários níveis, para o gerenciamento dos atrativos, para o desenvolvimento de infra-estrutura baseado nas necessidades reais do setor, para a educação ambiental de turistas e empresários e para o envolvimento das comunidades locais, visando o desenvolvimento regional. Por conseguinte, o próprio regime jurídico pode facilitar quanto à adequação dessa atividade em ambientes frágeis e de grande sensibilidade.

Portanto, é evidente que sem a definição de um novo modelo de ação integrada e de gestão compartilhada com base local, o desenvolvimento do ecoturismo vinculado a UCs tende a ser lento e problemático. Por isso, da importância da legislação estabelecer que essas áreas poderão ser geridas por organizações da sociedade civil de interesse público com 
objetivos afins aos da unidade, mediante convênio ou contrato com o órgão responsável por sua gestão.

Enfim, são inúmeras as vantagens favoráveis ao desenvolvimento do ecoturismo em áreas protegidas no Brasil, mas também são ilimitados os problemas e conflitos a serem equacionados como pré-requisito à atividade. É importante, no entanto, que a discussão desse tema considere o valor patrimonial global das áreas protegidas para a nação brasileira e que o planejamento do ecoturismo nessas áreas deva ser um processo transparente e que tenha o compromisso de engajamento efetivo de toda a sociedade civil, afinal de contas, o desenvolvimento socioeconômico sustentável deve ser o objetivo maior do ecoturismo, principalmente em se tratando de espaços protegidos. 


\section{CAPÍTULO 5}

\section{PARQUE ESTADUAL DA SERRA DOURADA}

\section{1 - Contextualização Histórica e Geográfica do Parque}

A Serra Dourada é um anteparo para a Cidade de Goiás, que acaba envolvida por seus contrafortes. Com suas escarpas, formações de arenito e com seus campos altos, esta região representa especial valor ecológico, devido à fauna, flora e às veredas de onde nascem os rios. Ficou famosa pelas areias das mais diversas cores, e como já dito em capítulos anteriores, imortalizadas pelas obras de arte de Goiandira Aires do Couto.

À tarde, reflete a luz do sol provocando o efeito dourado que também lembra o ouro na origem da região. Vale destacar, que a Serra Dourada foi uma das regiões com maior concentração aurífera no Estado de Goiás e ainda hoje, possuem alguns resquícios desse ouro, com os garimpos ainda existentes na área. Também corta a serra, um trecho de estrada antiga, do mesmo período da Estrada Imperial, que ligava Goiás a Mossâmedes e por onde também passaram os bandeirantes quando da colonização do Estado.

No ano de 1988, ocasião em que houve retorno do garimpo no Rio Vermelho (rio que corta a Cidade de Goiás), ocorreu todo um processo de degradação ambiental decorrente justamente da atividade de mineração. Nesta época, foi movida uma ação na justiça que conseguiu fechar o garimpo. Nesse mesmo período foi fundada uma Organização Não- 
Governamental na cidade (Grupo Canoe - grupo de amigos praticantes de canoagem) que foi a primeira ONG ambientalista do município. A partir de então, foram sendo desenvolvidas uma série de atividades de educação ambiental com os proprietários rurais, bem como, foi feito um diagnóstico ambiental do rio Vermelho da nascente até a foz do Rio Araguaia (350 km de rio).

Em seguida, surgiu o Grupo Canoe Júnior, que é um segmento do Grupo Canoe, que começou a realizar um trabalho de educação ambiental com crianças. Depois deste trabalho de educação ambiental com crianças, duas outras ONGS ambientalistas foram fundadas. Uma delas é o Grupo Amigos da Natureza, que desenvolveu um trabalho de educação ambiental no sentido de preservação dos recursos hídricos, e especialmente, dos atrativos turísticos, como por exemplo, o trabalho de mutirão de limpeza nos rios, portanto, junto às pessoas que freqüentavam os lugares. A outra ONG foi a Acif - Associação de Combate a Incêndios Florestais, e uma parte da Acif fundou uma outra ONG - Grupo Anjos Verdes.

Constata-se então, que esse processo de degradação ambiental na região, que tem uma paisagem extremamente bonita e uma riqueza ambiental muito grande, propiciou nos moradores locais um aumento de consciência quanto à preservação desses recursos naturais.

No ano de 1997, a secretaria municipal de Meio Ambiente, na figura do então secretário, o Sr. Rodrigo Santana, já defendia a criação do Parque Estadual da Serra Dourada, bem como, a criação do Parque Municipal do Rio Vermelho. Nesta época não se conseguiu a criação do parque, mas por outro lado, em 1998 foi criada uma APA - Área de Proteção Ambiental, com 16.851 hectares que ia da estrada de Goiânia (GO) para a Cidade de Goiás, onde cruzava a Serra Dourada até o rio dos Índios. Sua área foi ampliada no ano de 2000 e toda a região de entorno da cidade (área urbana, nascentes do Rio Vermelho e distritos históricos em volta da antiga capital de Goiás), foram incluídos. Totalizaram-se 35 mil hectares de uma unidade de conservação da categoria de uso sustentável, criada por decreto estadual e sob responsabilidade da Agência Ambiental do Estado de Goiás.

Mesmo não se conseguindo a criação do parque, segundo o geógrafo, o Sr Rodrigo Santana, a população local continuou na luta de criação do mesmo, visto que, acreditavam que ainda se permanecia a ineficácia do poder público estadual. Entendiam que precisavam implantar uma unidade de conservação de categoria de proteção integral porque a APA não 
estava conseguindo frear a ocupação e o parcelamento desordenado do solo, especialmente a degradação das faixas ciliares dos rios, da vegetação de encosta e o parcelamento e crescimento desordenado também da cidade.

Assim, a demanda pela criação de uma Unidade de Conservação de Proteção Integral que envolvesse a Serra Dourada, mais especificamente da categoria de Parque Estadual, surgiu entre a população vilaboense, já na década de 1990, e tendo sido manifestada até o presente, por atos e documentos de caráter público, dentre os quais, três ofícios destinados às autoridades do poder executivo estadual e um abaixo-assinado. E foi através de uma ONG Núcleo de Consciência e Cidadania, presidida pelo Sr. Rodrigo Santana, que foi feito esse movimento de coleta de mais de 10 mil assinaturas pedindo a criação do parque em abril de 2003, documento este, entregue ao governador.

Vale destacar, que as assinaturas foram colhidas somente na Cidade de Goiás porque foi um movimento que partiu do próprio município, mas os outros municípios que possuem áreas dentro da Serra Dourada (Buriti de Goiás e Mossâmedes), também apresentaram interesse quanto à criação do parque e de fazerem parte do conselho gestor que ainda vai ser implementado. Foram realizadas audiências públicas em Mossâmedes e na Cidade de Goiás e os prefeitos, vereadores e representantes das três comunidades foram convidados a participar.

Foi desta forma, que em abril de 2003, foi solicitada pelo corpo diretivo da Agência Ambiental, entidade executora da política ambiental do Estado de Goiás, e mais especificamente ao seu Departamento de Áreas Protegidas, a realização de um estudo técnico de viabilidade de criação do Parque Estadual, tendo o mesmo, vindo a ser criado no mês de junho do mesmo ano com atual área de 30 mil hectares.

Nesse processo de estudo de viabilidade de criação do parque, participaram o geógrafo e vereador municipal, o Sr Rodrigo Santana e duas técnicas da Agência Ambiental, a Sra. Lívia Leite, bióloga e gestora de recursos naturais, bem como, a Sra. Denise Daleva, geógrafa e também gestora de recursos naturais e chefe do departamento de Áreas Protegidas deste órgão.

O estudo técnico, por se tratar de um documento preliminar à criação da unidade, não costuma conter inventários ou levantamentos exaustivos das características bióticas, físicas e 
sócio-econômicas, senão uma caracterização destes aspectos que atenda aos pré-requisitos para identificação da vocação e categoria da unidade a ser criada. Conteúdos mais detalhados deverão ainda ser criados quando da elaboração do Plano de Manejo, após o ato de criação da UC.

Foram realizadas pesquisas bibliográficas, cartográficas e de sensoriamento remoto em gabinete e mais dois trabalhos de campo num nível de reconhecimento, sendo o primeiro, dos dias 26 a 28 de abril de 2003 e o segundo, no dia 10 de maio do mesmo ano. Foram percorridos 200 quilômetros de carro e 16 quilômetros a pé.

No relatório do Estudo Técnico, que me foi disponibilizado pela Sra. Lívia Leite, que é gestora da Agência Ambiental, segundo a metodologia utilizada em gabinete (estudo em escritório), em que em um primeiro momento partiu-se de uma observação regional, identificando e delimitando unidades de paisagem, por meio do sensoriamento remoto e de cartas topográficas. Este procedimento permitiu estabelecer as rotas das vistorias de campo, distribuindo-as também de acordo com os recursos e o tempo disponível para o trabalho local.

Em campo, as rotas foram rediscutidas e ajustadas com o representante do Poder Público Local, o vereador Rodrigo Santana, que indicou pontos prioritários, acessíveis e privilegiados de observação. Posteriormente, adquiriu-se imagens de satélites recentes, georreferenciadas e em escala, junto ao setor de geoprocessamento da Agência Goiana de Indústria (AGIN), levando a equipe novamente a campo para verificar, elaborar e propor os limites do parque com maior precisão.

Durante o processo de estudo de viabilidade foi percorrida então toda a extensão do parque, se conversando com as comunidades e com as autoridades, fazendo reuniões nas câmaras municipais e todo um levantamento da unidade de conservação (UC) onde se detectou e constatou que além de ser viável a criação do parque, essa é uma área que tem um potencial muito grande para o desenvolvimento do ecoturismo e de atividades ligadas à educação ambiental e pesquisa.

Segundo os levantamentos realizados, a Serra Dourada de Goiás insere-se nas faixas de dobramentos do ciclo brasiliano (cinturões orogênicos), associada ao cinturão de Brasília, na unidade morfoestrutural denominada Planaltos de Goiás - Minas. Esta unidade estende-se 
desde o sul do Estado de Tocantins até o sudoeste de Minas Gerais, na região da Serra da Canastra, e configura uma seqüência de verdadeiras serras residuais, como ocorre com as Serras da Canastra (MG), da Bocaina, Dourada e Geral do Paraná, em Goiás - Tocantins.

Essas serras, e, portanto a Serra Dourada em particular, são resíduos das antigas dobras (orogênese) e constituem-se em alinhamentos de cristais, estreitas e alongadas. São sustentadas com freqüência por rochas metamórficas, sobretudo quartzitos. As direções e ângulos das camadas das rochas evidenciam a intensa movimentação tectônica a que foi submetida à região aonde se ergue a Serra Dourada. Já os solos que se desenvolvem na região são predominantemente litólicos na serra, ou seja, solos com teores elevados de minerais primários e cambissolos no entorno, que são solos em estágio primário de formação.

O clima regional está submetido à ação da massa ou sistema Tropical continental no outono-inverno, responsável pela estação seca, e do sistema Tropical atlântico, na primaveraverão. Localmente, devem ocorrer variações topoclimáticas devido ao efeito da morfologia da serra, quanto a altura, direção do alinhamento dos cristais, declividade e orientação das vertentes.

Quanto à hidrografia, as principais bacias da face norte da serra são, de leste para o oeste, a partir da GO-070, a do Córrego Bagagem, Córrego Aguapeí, Córrego Água Fria e Córrego Caxambu. Todos estes drenam para o Rio Vermelho, que drena para o Rio Araguaia. A face sul tem duas bacias principais, sendo a leste, a bacia do Rio Urú e a oeste a Bacia do Rio Fartura.

A vegetação natural predominante na área de estudo é constituída basicamente pelos subsistemas campestre, cerrado strictu-sensu, mata, veredas e ambientes alagadiços e mata ciliar ripária do Bioma Cerrado.

No subsistema campestre, que corresponde a um tipo de vegetação baixa e média, exibindo maciçamente um conjunto herbáceo-graminoso, com subarbustos e arbustos bem espaçados, observa-se à formação de campo sujo e rupestre. Na formação de campo sujo, o espaçamento entre as árvores nas encostas (vertentes) é em torno de $5 \mathrm{~m}$. A formação campo rupestre ocorre em áreas com altitudes superiores a $800 \mathrm{~m}$. É um tipo de vegetação que cresce sobre os afloramentos de rochas, geralmente quartzitos e metaxistos. A vegetação lenhosa 
aparece na fenda das rochas em solos rasos ainda em formação e provoca muitas vezes a desagregação de blocos rochosos. Algumas espécies estabelecem-se diretamente sobre a rocha ou nos acúmulos de musgos e formam uma flora característica. Observa-se, entre outras, Vochysia, Tibouchina, Cactus, Vellozia, Orquidáceas e Bromeliáceas. Nessa formação, foi observada uma espécie endêmica da região identificada como Tibouchina papirus.

O subsistema cerrado strictu-sensu corresponde à paisagem típica dos cerrados. Tratase de um corpo vegetacional com significativa expressão dada por seus elementos arborescentes (árvores e arbustos, entremeados por subarbustos e cipós) e com vegetação rasteira menos densa do que nos campos, provavelmente devido ao seu dossel (cobertura ornamental) mais compacto - entre $30 \%$ e $60 \%$ de cobertura. É um subsistema caracterizado por árvores de pequeno e médio porte, com acentuada tortuosidade e aspecto xeromórfico, ou seja, que não sofre deficiência hídrica. Encontra-se, entre outras espécies, Cariocar brasiliense (pequi), Byrsonima verbascifolia (murici), Hymenaca stigonocarta (jatobá), Bowdichia virgilioides (sucupira), além disso, vale ressaltar que a área do parque é muito rica em espécies vegetais frutíferas e medicinais.

A Mata Ciliar é o tratamento genérico para todos os ambientes florestados que acompanham os cursos d'água de diversa natureza. Os ambientes ciliares desempenham funções ecológicas importantes para o sistema dos cerrados, servindo de corredores naturais de migração a uma fauna bem variada, distribuída por todos os demais sistemas. Destaca-se no parque a presença de Xylopia emarginata (pindaíba), Tabebuia (ipês), Inga edulis (ingácomum).

O subsistema de veredas e ambientes alagados corresponde a ambientes úmidos ou alagadiços, geralmente cabeceiras de rios, ou em locais onde o solo apresenta uma constante saturação d'água, formando verdadeiros pântanos. A paisagem constitui-se de palmeiras, principalmente a espécie Mauritia vinifera (buriti), e um estrato graminoso contínuo e perene, conservando-se o verde o ano inteiro.

O subsistema de mata ocorre nos interflúvios em várias áreas da província dos cerrados, com solo de boa fertilidade natural. Estruturalmente, compõe-se de espécies arbóreas que atingem até 30 metros de altura e estrato inferior com espécies variando entre 1 
- 12 m. Entre outras, as espécies mais encontradas na Serra Dourada são a Hymenaea courbail (jatobá) e Myracrodruon urundeuva (aroeira).

No que diz respeito à fauna, a região é rica em biodiversidade de aves, sendo local de reprodução do urubu-rei. Os mamíferos sofreram grande pressão devido à caça, mas de acordo com a observação de moradores, são encontrados na região catetos, veados-campeiro, veados-mateiro, antas e felinos de médio e grande porte. Constata-se também a presença de répteis (lagartos) e insetos variados.

Enfim, o estudo técnico permitiu, em um primeiro momento, uma avaliação favorável à criação do parque estadual na Serra Dourada, segundo critérios legais e técnicos. A área atual desse parque é então de 30 mil hectares, entre a GO-070 e a rodovia que liga o município Cidade de Goiás aos de Mossâmedes e Buriti de Goiás. Praticamente a área inteira está ambientalmente bem preservada, passível de ser integralmente protegida, mas com alguns setores localizados que, merecerão ser delimitados como zonas de recuperação. Portanto, a maior parte do ecossistema está preservada porque justamente uma das preocupações quando se delimitou a área do parque foi evitar que se incorporassem dentro dele, áreas que já tivessem sido muito degradadas.

Esses aspectos físicos e bióticos, aqui mencionados, fazem parte do diagnóstico de campo realizado pela Agência Ambiental para o estudo técnico da criação da unidade de conservação de proteção integral, na região da Serra Dourada, envolvendo os municípios de Buriti de Goiás, Mossâmedes e Cidade de Goiás Essa descrição mostra como essa área é realmente de grande importância ambiental e como é propícia para o desenvolvimento de atividades ligadas ao ecoturismo e de educação ambiental.

Já que em termos legais foi viável a criação dessa unidade de conservação, mostrarei por meio dessa monografia, a real viabilidade com relação à implantação do ecoturismo nessa mesma área, por meio das entrevistas e pesquisas de campo realizadas tanto com os moradores locais quanto com os turistas. 


\section{2 - Caracterização do Parque dentro do SNUC}

O Parque Nacional é o principal elemento dentre as áreas naturais protegidas brasileiras. As unidades dessa categoria, quando criadas pelo Estado ou pelo município são denominadas, respectivamente, Parque Estadual e Parque Natural Municipal. O Parque Estadual da Serra Dourada, localizado na Cidade de Goiás, bem como, nos municípios de Mossâmedes e Buriti de Goiás, insere-se, portanto, dentro dessa primeira categoria, uma vez que, sua administração está a cargo da Agência Ambiental do Estado de Goiás, que é o órgão responsável pelo gerenciamento das UCs no Estado.

Essa categoria de UC tem como objetivo básico, segundo o Sistema Nacional de Unidades de Conservação, à preservação de ecossistemas naturais de grande relevância ecológica e beleza cênica, possibilitando a realização de pesquisas científicas e o desenvolvimento de atividades de educação e interpretação ambiental, de recreação em contato com a natureza e de ecoturismo.

É bom deixar claro, que a visitação pública deve estar sujeita às normas e restrições estabelecidas no Plano de Manejo da unidade, às normas estabelecidas pelo órgão responsável por sua administração, e às previstas em regulamento. A pesquisa científica depende também de autorização prévia do órgão responsável pela administração da UC, pois geralmente nas áreas dos parques, devem existir zonas proibidas (intangíveis) para o uso público, que deverão ser somente abertas para estudiosos desenvolverem seus projetos.

Antes mesmo da criação da atual área do Parque Estadual da Serra Dourada, foi criada em 1969 a Reserva Biológica da Universidade Federal de Goiás - UFG, conhecida como Reserva “Professor José Ângelo Rizzo”, uma gleba doada pelo governo do Estado de Goiás à universidade. Atualmente a reserva está localizada dentro do parque, possuindo uma área de 16.851 hectares, onde está inclusa a Área de Proteção Ambiental - APA, a partir da rodovia que demanda à Cidade de Goiás até a cabeceira do Rio dos Índios. A reserva situa-se mais precisamente dentro dos limites do município de Mossâmedes e está sendo administrada pelo Departamento de Botânica da UFG.

Com boa infra-estrutura, a reserva possui laboratórios para pesquisa, alojamentos, vigilância integral, além de estar toda cercada. Devido à sua riqueza de recursos naturais, a 
reserva é utilizada para pesquisas por estudiosos nacionais e estrangeiros, entretanto, os turistas que já começam a freqüentar o parque entram pela entrada principal, que é justamente a entrada da reserva, fato esse, que é proibido pelo Sistema Nacional de Unidades de Conservação, pois segundo a legislação do SNUC, as reservas biológicas destinam-se exclusivamente a pesquisa, sendo proibida a visitação pública e a interferência humana.

Em entrevista realizada, o geógrafo e vereador Sr. Rodrigo Santana, informou-me que caso essa área continuar sendo visitada, dentro do futuro plano de manejo do parque, certamente os técnicos deverão estar sugerindo ou que seja mudada a categoria da UC, ou seja, que deixe de ser uma reserva biológica e passe a ser uma UC que permita atividade do ecoturismo, ou por outro lado, que seja proibida a visitação nessa área.

O Parque Estadual da Serra Dourada é de posse e domínio públicos, sendo considerado um bem inalienável e indisponível, ou seja, é intransferível. No caso específico das várias propriedades particulares incluídas nos seus limites, estas deverão, quando da execução do plano de manejo, serem desapropriadas e seus proprietários indenizados pelo Estado.

Segundo o Sr. Rodrigo Santana, apesar de estarem satisfeitos com a criação do parque, existe ainda uma certa apreensão por parte dos proprietários rurais, pois estes, já querem saber quando vão ser desapropriados e como será feito o pagamento das indenizações, ou seja, qual será o valor a ser pago por alqueire. Em algumas propriedades em que as pessoas têm uma relação histórica e emocional com a terra, pois muitas das vezes foram transferidas de pai para filho, essas questões terão de ser discutidas mais detalhadamente e serem bem trabalhadas pelo conselho gestor do parque para se tentar chegar a um entendimento.

Além disso, um outro aspecto importante, é que em certas propriedades, as áreas já foram transformadas em pastagens e em alguns casos, os proprietários não concordam com a criação do parque, aonde certamente vão acontecer alguns debates, mas o conselho gestor também deverá ter maturidade para ouvir todos os envolvidos e chegar num bom termo.

O fato, é que em toda essa área que foi transformada em parque, a maioria das propriedades desenvolve a pecuária extensiva e a agricultura praticamente inexiste, isto porque, a qualidade do solo não permite. Portanto, realmente tornou-se uma região que tem 
vocação natural para ser unidade de conservação. Por isso mesmo, não há dúvida da necessidade e da importância de criação e implantação do parque com vistas a se proteger essa região que abriga uma série de espécies de animais que estão ameaçados de extinção e que é fonte de água e extremamente sensível a qualquer tipo de alteração no solo.

Conforme o SNUC, as unidades de conservação como os parques, devem possuir uma zona de amortecimento, ou seja, no entorno da unidade, as atividades humanas estarem sujeitas a normas e restrições, com o propósito de minimizar os impactos negativos. Quando da elaboração do Plano de Manejo do Parque Estadual da Serra Dourada, que segundo o Art.

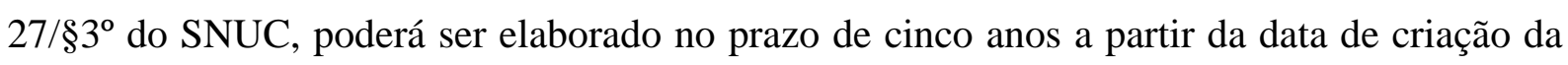
unidade, assim sendo, se deverá estipular então uma zona como essa mencionada.

Enfim, esses ambientes naturais protegidos são de imenso valor patrimonial, pois seus recursos podem ser utilizados na melhoria da qualidade de vida humana, além é claro, de poder representar importante fator de rentabilidade econômica, e para tanto, é necessário que a implantação de uma área do tamanho do Parque Estadual da Serra Dourada seja efetivada realmente de acordo com as regras previstas no SNUC, pois só assim terá maiores e melhores condições de atender aos verdadeiros princípios que regem a atividade de ecoturismo.

\section{3 - O Uso Turístico do Parque}

É fato, que a maioria das áreas protegidas de nosso país não estão preparadas para receber visitantes, pois muitas destas, não foram designadas nem projetas como locais turísticos, carecendo de fundos e de pessoal para satisfazer as necessidades dos viajantes.

Por isso mesmo, a maior parte dos administradores dessas áreas está enfrentando desafios de gerir o crescimento do turismo a fim de que possa ser benéfico tanto para os parques como para as comunidades vizinhas. Deste modo, os administradores deverão avaliar que nível de turismo é o melhor para cada área, como forma de assegurar que a mesma não seja excessivamente ocupada nem destruída por turistas, criar mecanismos capazes de gerar empregos e renda para as comunidades próximas e de oferecer educação ambiental aos visitantes. 
Além disso, o princípio da conservação deve estar sempre à frente das atividades de desenvolvimento do ecoturismo, prevalecendo sobre interesses ou necessidades da iniciativa privada, pois essas áreas naturais são a base do produto que se coloca no mercado. É de fundamental importância os gestores de parques conhecerem a legislação e suas respectivas restrições quanto a administração dessas áreas, que deverão estar contidas em regulamentos próprios no Plano de Manejo.

O planejamento de uma UC para o ecoturismo, como é o caso do Parque Estadual da Serra Dourada, terá por objetivo desenvolver um sistema de áreas de visitação, de infraestrutura de apoio aos visitantes, meios de interpretação ambiental, capacitação dos próprios gestores e dos prestadores de serviços. De uma maneira geral, o processo de planejamento do ecoturismo do Parque Estadual da Serra Dourada deverá considerar um levantamento de informações, de campo e mapeamento, e um diagnóstico e zoneamento do uso recreativo da área.

Assim sendo, quando da implantação do Parque Estadual da Serra Dourada, em um primeiro momento, foi necessário se avaliar a situação da área proposta, ou seja, qual o status dos recursos naturais dentro desse limite proposto. Esse trabalho, como mencionado no começo desse capítulo, foi desenvolvido pela Agência Ambiental do Estado de Goiás em um relatório descritivo de toda a área, bem como, daqueles recursos intactos ou ameaçados pela mineração e pela agricultura e/ou pecuária predatória.

De qualquer forma, o que pretendo expor nesse tópico do capítulo sobre o uso turístico do Parque Estadual da Serra Dourada, é que o desenvolvimento do ecoturismo envolve aspectos muito mais complexos do que apenas o gerenciamento interno dessa unidade de conservação, ou seja, o produto ecoturístico que poderá ser criado, deverá contemplar ainda, uma integração com a própria Cidade de Goiás e com a região a qual está inserida a serra.

Exatamente acreditando que o parque não conseguirá viver isolado, é que proponho então a regionalização do turismo para a Cidade de Goiás e conseqüentemente para esse próprio atrativo, ou seja, o uso turístico do parque deverá estar embasado em um programa de turismo mais amplo, que ao meu ver é o Programa Caminhos do Ouro, que será mais detalhadamente explicado no próximo capítulo. 


\section{CAPÍTULO 6}

\section{PROGRAMA CAMINHOS PARA O DESENVOLVIMENTO SUSTENTÁVEL DE GOIÁS}

Este capítulo tem por objetivo estar relatando um pouco o que é o Programa Caminhos para o Desenvolvimento Sustentável de Goiás, como forma de estar agregando valor a essa monografia, uma vez que, as propostas por mim idealizadas para o Parque Estadual da Serra Dourada, estão diretamente ligadas ao próprio Plano de Turismo do Estado. Por isso mesmo, cabe ainda dizer aqui que o respectivo programa foi idealizado inicialmente pelo SEBRAE/GO.

O Serviço Brasileiro de Apoio às Pequenas e Micro Empresas (SEBRAE), é uma entidade que trabalha desde 1972 em busca do desenvolvimento sustentável das empresas de pequeno porte. Para isso, a entidade promove cursos de capacitação, procura facilitar o acesso ao crédito, estimula a cooperação entre as empresas, organiza feiras e rodadas de negócios e incentiva o desenvolvimento de atividades que contribuem para a geração de emprego e renda. Hoje, o SEBRAE atua em todo o Brasil, por meio de unidades nos 26 Estados, bem como, no Distrito Federal, buscando então disseminar o empreendedorismo e o associativismo.

O SEBRAE/GO concentra seus esforços no sentido de uma ação integrada, articulada e sistêmica, pelo desenvolvimento econômico e social do Estado de Goiás, através de ações 
focadas em suas potencialidades setoriais, entre as quais destacam-se o agronegócios, o artesanato e o turismo. O propósito é buscar o crescimento desses setores, atrelado ao crescimento das condições de vida daqueles que dele participam.

Vale destacar, que paralelamente ao crescimento econômico e social, busca-se a garantia de preservação ambiental e cultural, e na visão do SEBRAE, é importante que Goiás seja visto pela comunidade nacional e internacional como um estado com crescente posicionamento preservacionista, mas ao mesmo tempo também é importante que a população possa aproveitar os benefícios desse posicionamento, para seu próprio crescimento.

O SEBRAE/GO, a AGETUR - Agência Goiana de Turismo, a Secretaria Estadual da Agricultura, a SEPLAN - Secretaria Estadual de Planejamento, a SEMARH - Secretaria do Meio Ambiente e Recursos Hídricos, a Secretaria Estadual de Ciência e Tecnologia, a Agência Rural, as Prefeituras Municipais, a Federação da Agricultura do Estado de Goiás, a Agência Ambiental, as Universidades, as Associações, os Sindicatos, as Organizações e outras entidades ligadas ao meio ambiente, à produção agrícola, ao turismo, à cultura e à cidadania, devem então unir forças pelo desenvolvimento particular desses setores.

Assim sendo, no ano de 2001 foi criado pelo SEBRAE/GO o Programa Caminhos para o Desenvolvimento Sustentável de Goiás, tendo como âncoras os segmentos mencionados anteriormente (agronegócios, artesanato e turismo).

Com características de integração entre ecologia, cultura, desenvolvimento econômico e cidadania, o programa passa pela combinação de ações locais de identificação e mapeamento dos potenciais turísticos e agroecológicos, com a identificação de suas deficiências, conscientização das pessoas envolvidas e com o despertar de seu público consumidor, culminando com ações específicas de busca da produção agroecológica, assim entendida a produção de alimentos ecologicamente adequados, sem agressão ao meio ambiente, livres de agrotóxicos, e em especial aos direcionados para o atendimento à demanda turística, estabelecendo-se alternativas para um modelo de desenvolvimento sustentável e integrado.

Através deste trabalho, o SEBRAE/GO e seus parceiros, têm a possibilidade de uma atuação concentrada, potencialmente direcionada, a serem trabalhadas sob forma de 
caminhos, estabelecendo-se um roteiro que permita a integração dos empreendimentos, a elaboração de guias sobre ecologia, alimentação e rotas turísticas, entre outros meios de divulgação. Inicialmente foram criados o (Caminho do Paraíso ou Biosfera), o (Caminho do Ouro) e o (Caminho da Ecologia ou do Sol). Posteriormente surge o (Caminho das Águas), o (Caminho dos Negócios) e o (Caminho da Estrada de Ferro).

- Caminho da Biosfera - Abrangendo uma região que tem como um destaque a cidade de Alto Paraíso. Partindo-se de Brasília, cidade mundialmente conhecida, pretende-se a organização de uma caminhada até São Domingos, passando pelas cidades de Planaltina, São Gabriel de Goiás, São João D’Aliança, Alto Paraíso, Cavalcante, Terezina de Goiás, Nova Roma e São Domingos. Os municípios goianos listados têm grande potencial ecológico e contam com uma população estimada de 100.000 pessoas, com problemas de ocupação e renda.

- Caminho do Ouro - Com foco no turismo histórico, seguindo-se uma rota que pode ser vista como o “Caminho dos Bandeirantes”, partindo-se do Brasília, como "ponto zero” e iniciando a caminhada em território goiano por Cocalzinho, seguindo-se Corumbá de Goiás, Pirenópolis, Petrolina, Taquaral, Itaberaí e Cidade de Goiás. Destacam-se, nesta rota, cidades com forte apelo histórico-cultural, como Pirenópolis e Cidade de Goiás. Os municípios citados contemplam uma população próxima de 130.000 habitantes.

- Caminho do Sol - Tendo-se como referência à “Caminhada Ecológica”, tradicionalmente realizada por andarilhos, partindo-se de Goiânia e passando por cidades como Goiânia, Inhumas, Itaberai, Cidade de Goiás, Faina, Araguapás e Aruanã. Em cada cidade é seguido um cerimonial em defesa do meio ambiente, com plantio de árvores e discursos focando a natureza. Esta região não se limita apenas às belezas do Rio Araguaia, mas o roteiro também inclui o Parque Nacional das Emas, bem como, os Sitos Arqueológicos de Serranópolis, e engloba uma população superior a 1.500.000 habitantes.

- Caminho das Águas - Estão nesse caminho os municípios e localidades que possuem recursos hídricos com potencial turístico. As águas quentes das fontes termais, com os lagos de barragens para a produção de energia elétrica no vale do Rio Paranaíba, fazem parte desse caminho, bem como, as águas de Caldas Novas, de Rio Quente, a cidade de Lagoa Santa, que é banhada de águas medicinais, a cidade de Cachoeira 
Dourada e suas fontes quentes e ricas em sais, e no sul de Goiás o Lago de São Simão e Três Ranchos.

- Caminho da Estrada de Ferro - Tem o propósito de revitalizar os trilhos da Estrada de Ferro do Estado, levando o desenvolvimento para essas regiões e dotando as mesmas, de toda uma infra-estrutura que possa proporcionar conforto e segurança aos passageiros, assim, a Estação de Trem que um dia fez parte do cotidiano destas cidades, terá nesse projeto a mesma ideologia do passado e abrangerá ainda aspectos culturais e pedagógicos que atenda aos interesses do turismo cultural.

- Caminho dos Negócios - Caracteriza-se por municípios com infra-estrutura respaldada por hotéis, restaurantes e espaços direcionados à realização de eventos e congressos. São cidades como Goiânia e Anápolis, de grande importância econômica para o estado.

Basicamente então, os pontos favoráveis para a elaboração desses programas ocorrem pelo potencial de pesca esportiva e lazer do vale do Araguaia; pelo potencial de ecoturismo na Chapada dos Veadeiros; pelo potencial de lazer nas águas quentes e região dos lagos; pelo potencial cultural nas cidades históricas; pela tradição das antigas estradas de ferro; pela pujança econômica do estado e pelo povo hospitaleiro e de cultura original.

Mapear os segmentos rurais e urbanos potencialmente turísticos, levantar suas condições favoráveis e críticas, estabelecer estratégias de criação de ambientes turísticos, por meio de investimentos, conscientização e capacitação dos proprietários rurais, pequenos empresários e potenciais empreendedores, são, portanto, meios para a criação de um novo filão no turismo e nos agronegócios goianos.

O SEBRAE tem como objetivos específicos desse Programa:

- Buscar o desenvolvimento de ações integradas para a efetiva participação das MPE Micro e Pequenas Empresas -, e de pequenas propriedades rurais em atividades ligadas ao turismo e à produção de alimentos agroecológicos, em especial sob a forma associativa;

- Buscar a promoção do fortalecimento das relações entre os órgãos públicos federal, estadual e municipais, com a iniciativa privada dos municípios e setores envolvidos; 
- Incentivar o intercâmbio com entidades nacionais e internacionais, a fim de promover a captação e a geração de eventos para os municípios, no sentido de minimizar os efeitos de sazonalidades;

- Contribuir para a formação e capacitação dos profissionais que prestam serviços para o turismo e para agronegócios;

- Buscar a ampliação do potencial turístico e de agronegócios das regiões e municípios priorizados, pela conscientização e capacitação da comunidade e mobilização de potenciais empreendedores;

- Captar e disseminar informações sobre tecnologias para empresários e produtores potenciais da cadeia alimentar;

- Viabilizar condições favoráveis ao acesso das MPE e de potenciais empreendedores às linhas de crédito;

- Trabalhar para a elevação dos níveis de participação da mão-de-obra ocupada pelas MPE instaladas nas regiões que integram os pólos turísticos do Estado de Goiás;

- Incentivar a legalização das MPE;

- Internamente, pretende-se uma difusão de informações técnicas do setor turístico pelas diversas áreas do agente, culminando com uma abrangente e completa proposta de intervenção pelo atendimento dos propósitos específicos e estratégicos estabelecidos.

Assim, é entendido que a abordagem do mercado a partir do turismo deva dar-se à luz de um amplo estudo, a ser posteriormente objeto de atualizações constantes, que permita o levantamento de indicadores sobre as cidades listadas na segmentação, buscando-se dados sobre qualidade de vida, exclusões sociais, modelos de gestão, potencialidades comuns e particulares, grau de envolvimento das sociedades locais, concentrações urbanas e rurais, produção agrícola, condições e locais de hospedagem, alimentação e lazer, infra-estrutura básica, atividades lucrativas, equipamentos e serviços disponíveis aos turistas, modelos de administração do município, existência de organismos voltados para os aspectos do turismo, etc.

A execução do projeto está a cargo do SEBRAE/GO, onde fica sediada a coordenação geral, e um dos responsáveis e colaborador nessa entidade é o Sr. Joel Rodrigues Rocha, administrador e consultor, cuja atuação é junto à gestão das Unidades Setorial e Regional do SEBRAE/GO. Apesar de ter sido criado pelo SEBRAE/GO, o Programa Caminhos já 
apresenta parceiros efetivos na realização desse trabalho, em especial a AGETUR (Agência Goiana de Turismo), principalmente através de sua Gerência de Planejamento e Pesquisa, cuja atribuição é estar identificando as áreas prioritárias para o desenvolvimento do turismo, ou seja, quando a AGETUR adotou o Programa em janeiro de 2002, este já havia sido criado pelo SEBRAE/GO.

Antes de qualquer coisa, é bom exemplificar que a AGETUR, criada em 1999 pela Lei n. ${ }^{\circ}$ 13.550, é uma entidade autárquica Estadual, dotada de personalidade jurídica de direito público interno, com autonomia administrativa, financeira e patrimonial, jurisdicionada a Secretaria de Indústria e Comércio, tendo como alguns de seus objetivos: contribuir para a qualidade dos serviços turísticos no âmbito do Estado; firmar convênios, acordos, contratos e parcerias com pessoas físicas ou jurídicas, de direito público ou privado, nacionais ou internacionais, a fim de melhorar e inovar o setor turístico no Estado; pesquisar fontes de financiamento, planejar e desenvolver programas e projetos com vistas ao fomento da atividade como um todo, entre outros mais.

A AGETUR, através dessa Gerência em particular, apresenta pesquisas desenvolvidas com as Instituições de Ensino Superior, por meio dos alunos de Turismo, referente ao perfil, motivação e percepção do visitante que freqüenta os municípios inseridos no Programa Caminhos. Além disso, a Secretaria de Planejamento (SEPLAN) e a Agência Ambiental são parceiras, apesar de diferir com relação à metodologia de trabalho.

A AGETUR, na realidade possui quatro vertentes principais de atuação, não trabalhando efetivamente o Caminhos como um Programa, como é o caso do SEBRAE. Essas linhas de atuação estão inseridas dentro da Política Estadual de Turismo através da proposta do Plano Plurianual - PPA 2004- 2007. Já é sabido, que o PPA é um instrumento por meio do qual os órgãos governamentais definem os investimentos e despesas, organizados em programas que resultem em bens ou serviços para o atendimento da sociedade, por um período de quatro anos. Esses Programas são:

- Programa de Infra-Estrutura Turística - Dotar os pólos turísticos de condições adequadas para recepcionar, instalar, e apoiar o turista, a fim de viabilizar os produtos no mercado nacional e internacional. Algumas medidas são a implantação e implementação da sinalização turística, a viabilidade de implantação de novos Centros 
de Convenções, uma melhoria nos terminais de passageiros, construção e melhoria dos Centros de Atendimento aos Turistas (CAT), entre outros.

- Programa de Informações Turísticas - Busca suprir a falta de informações tanto para a tomada de decisão em relação às políticas públicas, bem como, para investimentos do setor privado, que necessita de dados para subsidiar suas decisões sobre oportunidades de negócios, compartilhando informações entre o trade turístico, pesquisadores de turismo, acadêmicos e turistas.

- Programa de Produto Turístico - Está focado na formatação dos produtos, ou seja, utilizar o potencial na elaboração de pacotes, permitindo a sua comercialização no mercado. Assim, se faz necessário promover a melhoria das atividades desenvolvidas pelo trade, a gestão municipal ou da região, a qualificação do profissional da área, o incentivo a criação de novos produtos turísticos para serem divulgados, o cadastramento dos empreendimentos existentes, etc.

- Programa Mostra Goiás - Apesar de possuir atrativos naturais e culturais, Goiás é responsável por um fluxo nacional de turistas ainda pequeno, por isso, esse programa visa promover as potencialidades em nível nacional e internacional, transformando o Estado em um dos principais destinos turísticos do país.

Esses programas da AGETUR atuam em todos os destinos do Programa Caminhos. No Caminho do Ouro (foco principal de meu projeto), por exemplo, tem-se a aplicação desses quatro programas, portanto, o Programa Caminhos na visão da AGETUR, é uma espécie de ordenamento para se intervir na região, enquanto que os 04 programas mencionados, são as ações nessas mesmas regiões. Apesar da atuação do SEBRAE não ser exclusivamente o turismo, por outro lado, a base do programa é a mesma, ou seja, estar intervindo nessas regiões e produzindo uma cultura de planejamento nesses municípios, que hoje contempla 72 em todo o Estado.

A AGETUR tem como meta para o Turismo - Plano Estadual, até 2007, implantar o sistema de informações turísticas, criando os núcleos de pesquisa nos principais destinos turísticos (um banco de dados de 20 municípios). Criar também novos destinos turísticos, ampliando a oferta turística; regularizar os empreendimentos turísticos do Estado e estar cadastrando os empresários na Gerência de Planejamento e Pesquisa. Finalmente se deve estruturar e definir que cara tem Goiás e o que o Estado quer vender lá fora como destino, devendo então se trabalhar esses produtos, formatando e colocando-os no mercado, a fim de 
ampliar o número de turistas que visitam o Estado, ou seja, Goiás tem que ter produto e preço, portanto, as operadoras devem negociar os produtos existentes.

Segundo a Sra. Flávia Rabelo (gerente de planejamento e pesquisa da AGETUR) o projeto do SEBRAE/GO “Goiás é bom demais!”, que é a versão do Projeto “Cara Brasileira” do SEBRAE Nacional, vai dar subsídios para se estar trabalhando o turismo. Este projeto foi proposto ao SEBRAE pelo sociólogo italiano Domenico De Masi, cuja versão estadual é estar atuando no turismo, na moda, artesanato, patrimônio natural e cultural, produtos alimentícios, gestão do conhecimento, econegócios e biodiversidade, buscando criar estratégias de promoção da imagem e dos produtos do estado.

Esse projeto é, portanto, uma maneira de fortalecer a imagem do país e do Estado no exterior, para favorecer a inserção dos produtos goianos no mercado internacional. Assim, estará se promovendo a geração de negócios a partir da agregação dos valores da cultura goiana aos produtos e serviços das micro e pequenas empresas, visto que, o Brasil tem uma identidade cultural riquíssima apesar de se utilizar pouco da mesma no que se refere a realização de negócios, e particularmente, quando se fala em vender o turismo no exterior.

Um fato novo a se mencionar com relação à atividade do Turismo no Brasil e que vislumbra exatamente a filosofia do Programa Caminhos, é que basicamente antes se trabalhava o município como destino, mas agora se fala em regionalização, ou seja, em trabalhar regiões e roteiros integrados. O PNMT (Programa Nacional de Municipalização do Turismo) da EMBRATUR (Instituto Brasileiro de Turismo) e do Ministério do Turismo, não mais existe, visto que, justamente não está se trabalhando com essa municipalização, mas com a regionalização.

O Ministério passou a municipalização para o Estado, que tem de estar trabalhando a base. Dessa maneira, somente depois que esses municípios, localizados em um mesmo espaço geográfico e que possuem potenciais em comum ou potenciais que podem um agregar o outro, que o Ministério então vem e trabalha a região. Segundo a Sra. Flávia Rabelo, os municípios têm-se mostrado bem interessados e ansiosos de estarem identificando o seu potencial para o Turismo. 
De acordo ainda com o Sr. Joel Rocha, o SEBRAE teve uma atuação bastante efetiva no Caminho da Biosfera em 2003, em particular nas cidades de Cavalcante, Alto Paraíso e Colinas, realizando inventários, diagnósticos, bem como, treinamento de guias locais. A AGETUR, por outro lado, está atuando junto a esses municípios com a pesquisa, com o manual de orientação aos municípios, com a questão da municipalização, a sensibilização e a criação do Conselho Municipal de Turismo (COMTUR), que é muito importante. As pesquisas são realizadas para preparar os municípios para receberem o turista, e os conselhos só estão sendo formados nos municípios que teve a municipalização (Oficinas Participativas de responsabilidade do estado).

Enfim, o desenvolvimento sustentável do turismo prescinde de uma permanente articulação entre os diversos setores públicos e privados, e o Fórum e os Conselhos Estaduais e Municipais, que contam com representantes de todos os segmentos envolvidos no processo, são as instâncias deste relacionamento. Portanto, visando este desenvolvimento é que a AGETUR, adotou então a estratégia do "Programa Caminhos para o Desenvolvimento Sustentável de Goiás”, ordenando as regiões e consolidando esses destinos junto à atuação de quatro vertentes principais (informação, infra-estrutura, produto e divulgação) buscando atender a demanda turística do estado.

Um passo importante para a estruturação dessa estratégia, foi à elaboração do Manual de Orientação aos Municípios, já mencionado nesse mesmo capítulo, que se trata de estratégia de desenvolvimento do turismo, onde se descreve as etapas para a preparação dos mesmos, bem como, os pré-requisitos e critérios de classificação, orientando-os no desenvolvimento do turismo sustentável.

Essa monografia tem como objetivo maior estar propondo que se amplie a oferta turística do estado, criando produtos nessa área, que contemple o Programa Caminhos do Ouro, uma vez que, a Cidade de Goiás está inserida dentro desse roteiro.

Minha proposta é justamente afirmar que caso seja adequadamente implementado e efetivamente estruturado o ecoturismo dentro do Parque Estadual da Serra Dourada, este poderá ser um produto a ser comercializado dentro de uma rota turística, - Caminhos do Ouro, que já é trabalhado, como um ordenamento territorial em diversos municípios que possuem características em comum. 
Sendo assim, a adoção do Programa Caminhos é o passo inicial, que facilita o estabelecimento de um roteiro, e permite a criação e integração de empreendimentos tanto por parte da iniciativa privada, quanto da iniciativa pública, como é o caso do Parque Estadual da Serra Dourada, visto que, a Agência Ambiental é o órgão responsável pela gestão das Unidades de Conservação (UCS) do Estado. Isso conseqüentemente dará lugar ao surgimento de um mercado regionalizado, ou seja, se em cada cidade que faz parte desse programa for criado produtos, isso estará possibilitando que o turista conheça toda uma região, e não apenas um município.

Cidades históricas já inseridas dentro do Programa Caminhos do Ouro são riquíssimas tanto em valores culturais quanto naturais e paisagísticos, por isso, nada mais apropriado do que aproveitar essa beleza como forma de elaborar produtos que atenda aos interesses do turismo cultural, histórico e ecoturismo. 


\section{CAPÍTULO 7}

\section{BENCHMARKING - CIRCUITO DA ESTRADA REAL}

\section{1 - Contextualização Histórica da Estrada Real}

Antes de qualquer coisa, é bom esclarecer, que esse capítulo revela o que foi a antiga estrada real e sua importância atual para o desenvolvimento do turismo nos estados de Minas Gerais, Rio de Janeiro e São Paulo. Esse circuito, atualmente é responsável pela inserção de vários municípios desses estados dentro de um contexto da atividade turística, isto em decorrência tanto pela sua importância histórica quanto pela beleza cênica da região.

Por isso mesmo, constatando essa bem sucedida iniciativa, utilizo-a como um processo de benchmarking nessa monografia, que de uma maneira geral, trata-se uma técnica de aperfeiçoamento gerencial utilizado pelas empresas, aonde determinadas organizações comparam seus produtos com aquilo que o concorrente tem de bom, como forma de estar melhorando o seu próprio empreendimento. Sendo assim, a explanação desse capítulo é mais um argumento forte que sustenta a idéia de se trabalhar o atrativo Parque Estadual da Serra Dourada como um produto inserido dentro de um programa regionalizado de turismo.

Então, como já é sabido, o termo Estrada Real refere-se aos caminhos trilhados pelos colonizadores desde a descoberta do ouro em Minas Gerais até o período de sua exaustão. Um passeio nessa estrada é um retorno à história, ou seja, é voltar no tempo dos tropeiros que 
chegavam em seus cavalos, e nos adultos e crianças que faziam festa com a chegada dessa tropeirada.

Por terem constituído, durante longo tempo, as únicas vias autorizadas de acesso à região das reservas auríferas e diamantíferas da capitania das Minas Gerais, os caminhos reais adquiriram, já a partir da sua abertura, natureza oficial. A circulação de pessoas, mercadorias, ouro e diamante eram obrigatoriamente feitos por esses percursos, constituindo crime de lesamajestade a abertura de novos caminhos. Isto porque, o interesse fiscal, base da política metropolitana para a região mineradora da colônia prevalecia, e por isso, essas rotas de comunicação com as minas deveriam ser controladas e fiscalizadas, para que nelas se pudesse extrair uma massa cada vez maior de tributos para o tesouro real.

Ao longo dos caminhos reais espalharam-se os antigos registros, ou seja, os postos fiscais de controle, alguns dos quais, ainda podem ser apreciados na atualidade. Eram de diversos tipos, como, por exemplo, os registros do ouro, que fiscalizavam o transporte do metal e cobravam o quinto; os registros de entradas, que cobravam pelo tráfego de pessoas, mercadorias e animais; os registros da Demarcação Diamantina, responsáveis pelo severo policiamento do contrabando e pela cobrança dos direitos de entrada na zona diamantífera; e contagens, que tributavam o trânsito de animais.

Os prédios desses registros eram instalados em locais estratégicos dos caminhos, como por exemplo, em passagens entre serras, desfiladeiros e margens de cursos de água. No interior desses prédios se colocava o pessoal empregado, dentre os quais pode-se destacar, um administrador, um contador, um fiel e dois ou quatro soldados.

O nome Estrada Real passou a aludir, então, àquelas vias que, pela sua antiguidade, importância e natureza oficial, eram propriedade da Coroa metropolitana. Durante todo o século XVIII, e também em parte do XIX, quando a era mineradora já se fora e os caminhos se tornaram livres e empobrecidos, as estradas reais foram os troncos viários principais nas quatro capitanias do centro-sul do território colonial - Minas Gerais, Rio de Janeiro, São Paulo e Bahia.

As estradas, por terem sido então os eixos principais do intenso processo de urbanização do centro-sul brasileiro, ao longo do seu leito ou nas suas margens passaram a se 
distribuir as centenas de arraiais, povoados e vilas em que se organizou a massa populacional envolvida com a economia da mineração e com as economias a ela associadas. O povoado à beira do caminho, geralmente, com o cruzeiro, a capela, o pelourinho, o rancho de tropas, a venda, a oficina e as casas de pau-a-pique simbolizou, durante longo tempo, o processo de nucleação urbana do centro-sul da colônia.

Já é sabido, que essas povoações e vilas foram visitadas e descritas pelos viajantes europeus do século XIX, que nos deixaram páginas e páginas de notas de viagem, sobre as paisagens e os núcleos urbanos que encontraram nas suas jornadas, pelos caminhos coloniais brasileiros. No caso especificamente do Estado de Goiás, destaca-se, Saint -Hilaire, Pohl e Burchell, que já foram inclusive mencionados nesse projeto anteriormente. Em Minas, podese citar, por exemplo, os naturalistas alemães Spix e Martius.

Desse modo, no auge da mineração, esses caminhos se viram então percorridos por imigrantes paulistas, baianos, pernambucanos e europeus, por tropeiros do sul e de São Paulo, por boiadeiros do rio São Francisco e do rio das Velhas, por sertanistas da Bahia e das vilas paulistas, por escravos negros e índios, por mascates, administradores reais, homens do fisco, soldados mercenários e milícias oficiais.

Essa expansão, no centro-sul do território colonial brasileiro, conformou um dos mais significativos movimentos de apropriação do interior do país, e de sua integração com a faixa litorânea. Assim, a história da penetração, do povoamento e da ocupação econômica do vasto interior brasileiro está intimamente vinculada justamente à abertura e à expansão das rotas terrestres e fluviais que varreram o território nos quatro séculos da colonização do país. Desde a chegada do português até as últimas décadas do século XIX, foi aberta uma infinidade de caminhos, num esforço de apropriação, pelo colonizador europeu, da massa territorial representada pelo conjunto de terras da porção oriental da América do Sul, onde hoje está o Brasil.

Não é novidade, que nesse processo foram dizimados ou escravizados os primeiros povos ocupantes dessas terras, representados pelos indígenas, no momento da chegada dos portugueses. Milenares rotas indígenas foram utilizadas para o avanço das bandeiras e entradas. Somando-se aos jesuítas, responsáveis pela descaracterização cultural dos povos, 
ainda que tenham se esforçado para preserva-los fisicamente, os bandeirantes e entradistas foram os principais agentes da destruição das tribos indígenas do território colonial.

Com a chegada dos africanos, os caminhos de penetração passaram a ser também obra do escravo negro. Incontáveis trilhas e estradas foram abertas e assentadas pela mão-de-obra escrava e os calçadões de pedra que ainda hoje podem ser encontrados no interior brasileiro, dão uma idéia do árduo esforço que representou a sua construção pelo braço afro-brasileiro. A história dos caminhos antigos tem as cores da guerra contra o indígena e da escravidão africana.

Pelas vias antigas trafegaram, especificamente quanto à região mineradora do interior de Minas Gerais, as tropas de burros e mulas, responsáveis pelo transporte do ouro e do diamante nela extraídos para os portos do litoral e, no sentido inverso, pelo abastecimento da capitania de alimentos, armas, pólvora, aguardente, ferramentas, roupas, produtos importados da Europa e outras mercadorias.

O gado bovino, criado nos famosos currais do rio São Francisco, de lá chegava às minas, pelas vias terrestres, para abastecer de carne a sua população. Os comboios de escravos índios e negros eram trazidos das vilas paulistas e do litoral para o trabalho nas minas pelos caminhos que varavam a serra da Mantiqueira e chegavam ao centro da capitania pelo sul.

Há registros de que até 1721, são três, os grandes caminhos coloniais de ocupação da região mineradora da capitania das Minas Gerais. São eles, o Caminho Velho, o Caminho Novo e o Caminho da Bahia. Esses três caminhos, aos quais se somou a via para o antigo Distrito Diamantino, hoje a estrada que liga Ouro Preto a Diamantina, constituíram as primeiras e principais rotas de ocupação e exploração econômica do território da capitania. Eram eles as estradas de ligação entre a região mineradora e as vilas paulistas, o Rio de Janeiro e a Bahia. Depois, surgiram outras vias, como é o caso da Estrada Imperial na Província de Goiás.

\section{Caminho Velho}

As evidências históricas indicam que tenha sido a bandeira de Fernão Dias a expedição da qual resultou a abertura do chamado Caminho Velho, via de ligação entre as vilas paulistas do vale do rio Paraíba do Sul e os primeiros núcleos mineradores do que se 
conhecia à época, como "sertão dos cataguás”, região indefinida que veio a constituir a porção central da capitania das Minas Gerais. Entre 1674 e 1681 a famosa bandeira varreu boa parte do atual território mineiro, fundando os primeiros arraiais da futura capitania.

O Caminho Velho foi, então, na fase inicial das descobertas auríferas, a principal rota de chegada e abastecimento da região das minas. Conectando as vilas paulistas de São Paulo de Piratininga, Mogi, Jacareí, Taubaté, Pindamonhangaba e Guaratinguetá, bem como, os portos do Rio de Janeiro e Parati, esse caminho, logo se tornou uma via larga e movimentada.

Com a descoberta das primeiras reservas de ouro de aluvião nas bacias dos rios das Velhas, Doce e das Mortes, tornou-se esse, o caminho utilizado pelas levas de aventureiros que acorriam à região das minas a partir dos núcleos urbanos paulistas. Logo se formaram, na rota do Caminho Velho, as primeiras vilas do ouro: a Vila Rica de Nossa Senhora do Pilar (Ouro Preto), a Vila do Ribeirão de Nossa Senhora do Carmo (Mariana), a Vila Real de Nossa Senhora da Conceição do Sabará, a Vila Nova da Rainha (Caeté) e a Vila de São João-DelRei.

\section{Caminho Novo}

Ao contrário do Caminho Velho, formado de forma mais ou menos espontânea a partir das incursões paulistas pela região centro-sul, de onde hoje está Minas Gerais, o Caminho Novo, nasceu de um projeto oficial da Coroa Portuguesa, com a preocupação em reduzir o tempo de viagem entre o litoral e as minas. Para a abertura de um caminho que abreviasse substancialmente o percurso entre o litoral e as minas, foi contratado o sertanista Garcia Rodrigues, filho do grande Fernão Dias e os participantes da bandeira de 1674 - 1681.

Em 1700, após muitas dificuldades, o sertanista conseguiu concluir a picada para pedestres, passando posteriormente a aprimorá-la para que desse trânsito também para animais de carga, com o objetivo de explorar o promissor privilégio do uso exclusivo da via. Alguns anos mais tarde, entre 1722 e 1725, foi aberta uma variante do trecho fluminense do caminho de Garcia Rodrigues, encurtando ainda mais a nova via.

Em algumas décadas, o Caminho Novo se tornaria a principal via de acesso do litoral sul do território colonial, à região mineradora da capitania das Minas Gerais. Há registros históricos de que o tempo de viagem entre o Rio de Janeiro e Vila Rica se reduzira 
dez dias, evitando-se ainda, pela nova via, os lamaçais da serra do Mar e a travessia marítima até Parati. Desta forma, já nas primeiras décadas do século XVIII o caminho estava totalmente pontuado por roças, pousos, ranchos e povoados, todos eles formados e desenvolvidos como bases de apoio para os viajantes da via.

A consolidação do Caminho Novo provocou poderosa transformação no contexto econômico e político colonial. A cidade do Rio de Janeiro passou a centralizar a rota de povoamento, abastecimento e circulação mercantil da região aurífera e diamantífera, suplantando as vilas paulistas e a Bahia como centro distribuidor de pessoas e mercadorias, para a capitania das Minas Gerais e como porto de escoamento do ouro. Desse modo, o Rio de Janeiro passou a enviar aos povoados e vilas mineradoras escravos negros, açúcar, cachaça, gado, feijão, arroz, farinha e os produtos importados da Europa, que, com o refinamento social da capitania das Minas Gerais, passaram a ser crescentemente demandados pela população local.

Do ponto de vista político, o Caminho Novo, significou que a supremacia paulista na região das minas estava definitivamente vencida, e os imigrantes passaram a ter um caminho direto para as minas, completamente independente dos entroncamentos paulistas do Caminho Velho. Nas últimas décadas do século XVIII, quando se preparava a tentativa libertária da Inconfidência Mineira, o Caminho Novo também se tornou via privilegiada de propagação de ideais republicanos. Entretanto, a tentativa revolucionária, que teve o alferes Joaquim José da Silva Xavier (Tiradentes) como seu grande líder, também ao longo desse caminho, presenciou o esquartejamento de seu corpo.

\section{Caminho da Bahia}

A abertura do grande caminho que levava, no final do século XVII e no seguinte, do vale do rio das Velhas ao Recôncavo Baiano não pode ser estabelecida com precisão pela pesquisa histórica. Sabe-se que os imigrantes, escravos negros, mercadores e boiadas que vinham do norte da colônia, seja pelo porto de Salvador, sejam oriundos das capitanias nordestinas, já antes do século XVIII podiam utilizar-se de uma extensa via que nascia aí, seguia o curso do rio Paraguaçu até a Vila de Rio de Contas, para atingir as margens do São Francisco. O Caminho acompanhava a margem direita do São Francisco para seguir, depois, pelo vale do rio das Velhas até a Vila Real do Sabará. 
Não se sabe ao certo se a rota teria sido obra de exploradores paulistas avançando pelo sul, ou se seria resultado do avanço de criadores de gado baianos e pernambucanos a partir do nordeste da colônia, ou mesmo pelos dois movimentos. O certo, é que esse caminho foi uma das mais amplas redes de circulação de mercadorias para a região das minas. O Caminho da Bahia era ainda o descaminho do ouro. A expressão, que tem hoje um sentido de algo alegórico, tinha no século XVIII um significado bem preciso. Pelos descaminhos se evitava o pagamento de quintos, direitos de entrada, direitos de passagem e de todos os outros tributos que pesavam sobre a população envolvida com o conjunto de atividades geradas pela mineração. Eram os caminhos do contrabando.

Pelo menos nas três primeiras décadas do século do ouro, o Caminho da Bahia, hoje o menos conhecido e explorado dos caminhos coloniais da região mineradora, liderou com folga a concorrência com o Caminho Velho e o Caminho Novo na circulação mercantil. Foi somente quando a cidade do Rio de Janeiro se firmou efetivamente como o grande entreposto da capitania das Minas Gerais que esse caminho perdeu em significação econômica.

Essas vias, hoje reunidas sob o nome de Estrada Real foram, assim, fundamentais na história do povoamento e da colonização de vastas regiões do território brasileiro, tornando-se verdadeiros eixos histórico-culturais de construção de parte da nossa história.

\section{2 - A Redescoberta dos Caminhos Reais}

Atualmente a redescoberta moderna dos caminhos reais tem ensejado uma série de projetos e ações voltados para a proteção e recuperação do seu patrimônio cultural, a sua exploração econômica e a reafirmação da sua importância histórica.

O meio acadêmico, paulatinamente começou a redescobrir os caminhos terrestres como tema importante na análise histórica da formação da economia e da sociedade coloniais. Um pouco explorado nas primeiras décadas do século XX, por historiadores, o tema dos caminhos foi posteriormente esquecido. A iniciativa da publicação do livro Estradas Reais Introdução ao Estudo dos Caminhos do Ouro e do Diamante no Brasil, de autoria de Márcio Santos, insere-se num esforço contemporâneo de reconstituir historicamente a formação e a 
expansão dos caminhos reais, além de publicações, como “De volta à Estrada Real” de Flávio Leão, e outras mais.

Paralelamente a esses projetos, grupos de pesquisadores e agentes culturais e sociais promoveram expedições ao longo das estradas reais, em um movimento que, de certa forma, orienta a ação das instituições públicas e privadas envolvidas com a questão.

Em novembro de 1999 ocorreu a primeira fase da Expedição Estrada Real, quando foram percorridos a pé, em sete dias, 180 quilômetros entre o Rio de Janeiro e Juiz de Fora. Assim, em 1999, o Programa da Estrada Real, foi concebido a partir de uma reflexão dentro da Federação das Indústrias de Minas Gerais, com apoios fundamentais do Ministério do Turismo, do Governo de Minas, das prefeituras, além do SESI, SENAI, SEBRAE e SENAC, sendo um marco na exploração do potencial turístico de uma das rotas históricas mais importantes do Brasil, compreendendo os caminhos entre o Rio de Janeiro (RJ) e Diamantina (MG). Tudo isso, também em um primeiro momento, como decorrência do apoio do próprio SENAC à “Expedição Spix \& Martius”, quando vários profissionais empreenderam uma viagem de Ouro Preto a Diamantina, percorrendo o mesmo trecho do caminho que os naturalistas alemães Spix e Martius, haviam feito entre 1817 e 1820.

Em abril de 2000 realiza-se a segunda fase, entre Juiz de Fora e Ouro Preto, quando são percorridos, também a pé, 300 quilômetros em 14 dias, além de coleta de informações, dados, documentos e imagens de natureza histórica, arquitetônica, ambiental e cultural, e em setembro desse mesmo ano, o SENAC lançou o livro "Estrada Real de Minas - Guia e Roteiro Ecoturístico”. Com essa publicação, coroou-se um trabalho pioneiro de resgate histórico e cultural de um dos mais importantes caminhos para a Capitania das Minas. Hoje, essa rota privilegiada pela natureza e pontilhada de pitorescas cidades que abrigam um precioso acervo histórico e artístico está se transformando numa rica e agradável destinação ecoturística.

Com relação à exploração econômica das estradas, uma das vertentes em que se têm trabalhado governos e empresários, é a possibilidade de que a recuperação e valorização desses caminhos passem especialmente pelo turismo e pelas economias a ele associadas. E justamente tendo isso em mente, é que tem atuado órgãos e agências governamentais como a Secretaria de Turismo de Minas Gerais, o SENAC/MG e a própria EMBRATUR. 
Assim, foi criado no ano de 1999 o Programa de Incentivo ao Desenvolvimento do Potencial Turístico da Estrada Real, por meio da lei $n^{0}$ 13.173/99, regulamentada pelo Decreto $n^{\circ}$ 41.205/00, ambos do governo do Estado de Minas Gerais, representando um esforço, no âmbito da normatização legal, de estimular o turismo nessa área.

Atualmente, o Programa Estrada Real tem tido continuidade através de um Programa Educativo que leva capacitação técnica para as comunidades, oferecendo apoio para que a gestão comunitária se paute em um planejamento sustentável. Os cursos oferecidos no programa são direcionados para a qualidade na prestação de serviços turísticos.

Paralelamente, a entidade disponibiliza oficinas de sensibilização para a preservação do meio ambiente, para o resgate e potencialização das manifestações folclóricas, do artesanato e da culinária típica, e para a preservação dos bens históricos. Esses cursos culminam na implementação do ecoturismo na região e vem contribuindo para a geração de ocupações e renda, manutenção do homem no interior, perpetuação dos valores e preservação do patrimônio natural.

São muitos os trechos que podem ser percorridos na Estrada Real e cada roteiro esconde tesouros históricos, culturais e de belezas naturais. Nessas trilhas, homens e mulheres de variada ordem buscaram espaços de sobrevivência e de produção de bens, e na busca, construíram vida, memória e história. Ir por esses caminhos é desbravar e penetrar no interior num percurso de prazer e de fuga do cotidiano.

Segundo dizem, “a Estrada Real, que antes era um lugar em que o ouro habitava, hoje é uma mina de ouro para o turismo”. Isto porque, tem atrações para o ecoturista, para os interessados em história, para amantes de cavalgadas, caminhadas, e outras atividades mais. Hoje, quem vive nessa região guarda na lembrança o tempo em que o ouro "brotava no chão" e acolhe como ninguém quem chega a essas paragens, que agora não é mais a tropeirada, mas sim os turistas.

A região da Cidade de Goiás, também possui ruínas da Estrada Real, por onde passavam as tropas de mulas carregando o ouro de Goiás para São Paulo, Rio de Janeiro e seus portos, com destino à Europa. Ligava Villa Boa ao extinto povoado do Ferreiro, Ouro 
Fino, Itaberaí, depois Pirenópolis, minas de Santa Luzia (Luziânia) e a travessia do Rio Grande. Era o único caminho permitido e hoje está aguardando recuperação, perdendo-se entre os currais de velhas fazendas.

O que pretendo com essa explanação sobre esses antigos caminhos, é na verdade, mostrar como um roteiro turístico que engloba vários municípios pode vir a dar certo, ou seja, a adoção da regionalização, e justamente, tendo como exemplo de sucesso o Circuito da Estrada Real, que pode ser seguido e adotado em outras regiões do país, especialmente na Cidade de Goiás, até porque, já existe o Programa Caminhos, que se trata de um ordenamento territorial em que os municípios possuem características comuns. Assim, o Caminho do Ouro, que já foi mencionado no capítulo anterior, favorece e fortalece ainda mais essa idéia.

O Parque Estadual da Serra Dourada, que é uma área ambiental de grande beleza natural e de riqueza histórica, pode vir a se tornar um produto a ser disponibilizado no mercado, através de sua inclusão no Programa Caminhos do Ouro, sendo assim, a implantação do ecoturismo nessa área seria apenas um dos vários produtos que poderiam ser criados nesses municípios que fazem parte desse caminho. Além disso, vale ressaltar que a iniciativa privada ou mesmo os órgãos governamentais, poderiam estar permitindo a formatação desses produtos.

Na Cidade de Goiás, outro produto que poderia fazer parte desse roteiro seria o próprio desenvolvimento do ecoturismo nos trechos da antiga Estrada Imperial, que não está localizado dentro do Parque, mas situado no morro do Cantagalo entre a Serra de São Francisco e também entre o Rio Vermelho, que era uma região que se chamava antigamente de Barreira do Norte. Portanto, apesar da verdadeira estrada real não estar localizada na Serra Dourada, mas no entorno da cidade, por outro lado, isso seria até um diferencial a mais para a cidade, uma vez que, a mesma estaria ofertando mais produtos e conseqüentemente oferecendo mais opções de lazer aos turistas.

O desenvolvimento do ecoturismo no Parque Estadual da Serra Dourada, dentro desse Programa Caminhos, pode então, estabelecer relações entre a vida material do passado, a paisagem e os costumes, à realidade de quem busca diversão, conhecimento e fuga do cotidiano. Reconhecer a Serra Dourada como um espaço turístico é estar elaborando uma 
construção cultural, dando sentido e significado as coisas e aos costumes das pessoas que viveram e que vivem nessa região.

Como diz Menezes “a alegria de ver um chafariz centenário em Glaura, de conversar entre duas igrejas de Acuruí, de participar de uma festa religiosa no Serro, de admirar a paisagem de Milho Verde, de perceber a paz de Itapanhoacanga, de aproveitar a hospitalidade de Córregos, de banhar-se em cachoeira de São Gonçalo do Rio das Pedras, de comer um pastel de angu em Conceição do Mato Dentro, de ouvir uma seresta em Diamantina, de admirar a lua em Catas Altas, de cochilar em um banco de varanda de fazenda dos arredores de Barão de Cocais, de tomar uma pinga em Sabará ou de ouvir os casos de tropeiros que (incrível) ainda existem pelas lindas trilhas da Serra do Cipó, tudo isso e muito mais é reservado ao turista que se dispõe a abrir seu coração para a percepção de outros cotidianos, muito distintos do seu" (disponível na Internet em: http://www.descubraminas.com.br, acesso em 2004).

Assim como a implantação do turismo na Estrada Real visa construí-la culturalmente, dando a ela significados históricos e preservando-lhe a memória, isso também pode ser feito no Parque Estadual da Serra Dourada. Para tanto, grandes esforços devem ser investidos para que isso ocorra, devendo-se propiciar aos turistas informações e estrutura para que seja possível a experiência turística. Além disso, a atividade de ecoturismo no parque deve também esperar do turista um desmedido amor ao ambiente natural, bem como, à vida material e aos costumes das pessoas que vivem nessa região.

É imprescindível não perder de vista o enfoque municipal. Sem o envolvimento das comunidades residentes muito pouco poderá ser feito, e por isso mesmo, da aplicação dos questionários junto à comunidade receptora a fim de saber o que pensam sobre a implantação do ecoturismo na Serra Dourada.

Esses antigos caminhos, que transcendem a história, a economia e a geografia da ocupação desse espaço, estão arraigados na própria cultura do povo brasileiro, cuja formação dependeu da ação secular de bandeirantes, escravos índios, negros, mercadores, tropeiros e aventureiros na abertura de picadas, trilhas e estradas no imenso interior brasileiro. Assim, permitir que seja desenvolvido o ecoturismo no Parque Estadual da Serra Dourada, estará ao mesmo tempo se contribuindo e tornando possível a manutenção de nosso patrimônio natural e cultural, visto que, a Serra Dourada faz parte da formação histórica do povo goiano. 


\section{CAPÍTULO 8}

\section{PESQUISA DE CAMPO}

O Instrumento de atuação principal dessa monografia foi um conjunto de questionários aplicado em períodos distintos, com a seguinte distribuição: no Carnaval (30 questionários), na Semana Santa (30 questionários), em um final de semana comum (apenas 08 questionários) e no FICA (30 questionários). Essa pesquisa de campo foi o suporte empírico desse projeto, visando rastrear tendências e coincidências com a própria pesquisa realizada pela AGETUR quanto ao perfil do visitante que freqüenta a Cidade de Goiás.

Por isso mesmo, este capítulo em um primeiro momento, apresenta alguns dos gráficos tabulados pela AGETUR, e em seguida, alguns gráficos com base na pesquisa de campo realizada, com o objetivo de verificar, através da contrastação, as já referidas convergências. Utilizo, portanto, a pesquisa da AGETUR como fonte secundária e “corpus auxiliar” nessa monografia, uma vez que, os questionários que apliquei contrastam com essa pesquisa de arquivo.

A pesquisa de campo foi realizada no município durante esses períodos mencionados, abordando os turistas nos museus da cidade. Posso afirmar, que a maioria dos turistas (um total de 48 pessoas entrevistadas) foram receptivos e não se negaram em nenhum momento a responder as perguntas. Os moradores da cidade (num total de 50 pessoas entrevistadas), também se mostraram bastante abertos quanto a disponibilizarem os dados por mim solicitados, chegando às vezes, a complementarem informações que nem chegaram a ser pedidas de fato. 
A pesquisa da AGETUR, por outro lado, foi realizada no ano de 2002 com um total de 620 questionários, os quais foram aplicados durante a Semana Santa e o FICA, com o objetivo de conhecer os turistas que visitaram a Cidade de Goiás durante esses períodos e tendo em vista à identificação do perfil, motivação e percepção dos mesmos com relação ao município.

De acordo com essa pesquisa, os turistas que visitaram a Cidade de Goiás é a maioria do sexo masculino na Semana Santa (52,71\%) e do sexo feminino no FICA (52,54\%). São em geral, pessoas solteiras, provenientes de Goiânia e do interior do Estado, cuja faixa etária varia de 22 a 40 anos. Esses turistas apresentaram também, um gasto médio diário maior no FICA do que na Semana Santa.

O tempo de permanência dos turistas nesses dois eventos foi de 1 a 3 dias, sendo constatado que os mesmos, também viajam geralmente em feriados e em finais de semana para a Cidade de Goiás. Verificou-se ademais, que um número bastante significativo de pessoas já havia estado na região.

Evidenciou-se que na Semana Santa os turistas viajaram com seus grupos familiares (25,63\%) e no FICA predominou o deslocamento em grupo de amigos (43,33\%). Os dados revelam que na Semana Santa a maioria dos visitantes hospedou-se em hotéis/pousadas (45,36\%) e no FICA, a maior parte acomodou-se em casa de amigos (29\%).

A pesquisa revela que a grande maioria das pessoas desloca-se para a cidade com o intuito de viver experiências novas e diferentes, sendo a televisão responsável pela informação sobre a região e conseqüentemente, pela indução dessas viagens. No que tange às expectativas dos turistas, a maioria foi atendida com relação a esse item, mas por outro lado, a maioria não encontrou guias na região, vindo, portanto, a reclamar desse quesito.

A seguir, estão alguns desses dados coletados em forma de gráficos, bem como, aqueles relativos à própria pesquisa de campo. 
PERFIL DO TURISTA

Observa-se que em algumas questōes nå̃o foi atingido $100 \%$ das respostas.

Fig. 1: Regibes de origem

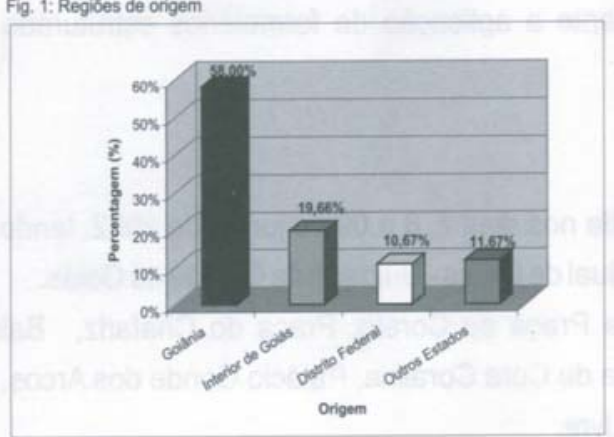

Fonte: AGETURNudieo de Perquin:

A pesquisa realizada na Cidade de Goiás revelou que a maioria dos turistas sảo originários do Estado de Goís com $77.66 \%$, sendo $58.00 \%$ de Goìnia, $19.66 \%$ do interior do Estado, $10.67 \%$ do Distrito Federal e $11,67 \%$ vindos de outros estados.

Fig. 9: Renda pessoal

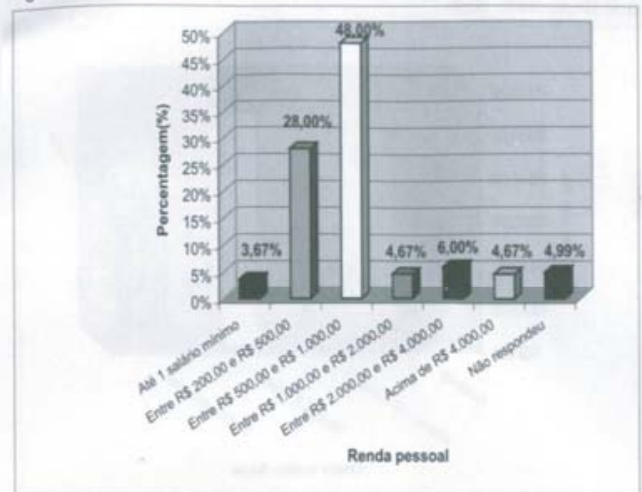

Fonte: AGETUR/ Núdeo de Pesquisa

No que tange a renda pessoal dos entrevistados, $48 \%$ se enquadram entre os que têm ganho mensal entre R\$ 500,00 e R\$ $1.000,00,28 \%$ entre R\$ 200,00 e RS 500,00 e 6\% entre R\$ $2.000,00$ e RS $4.000,00$.

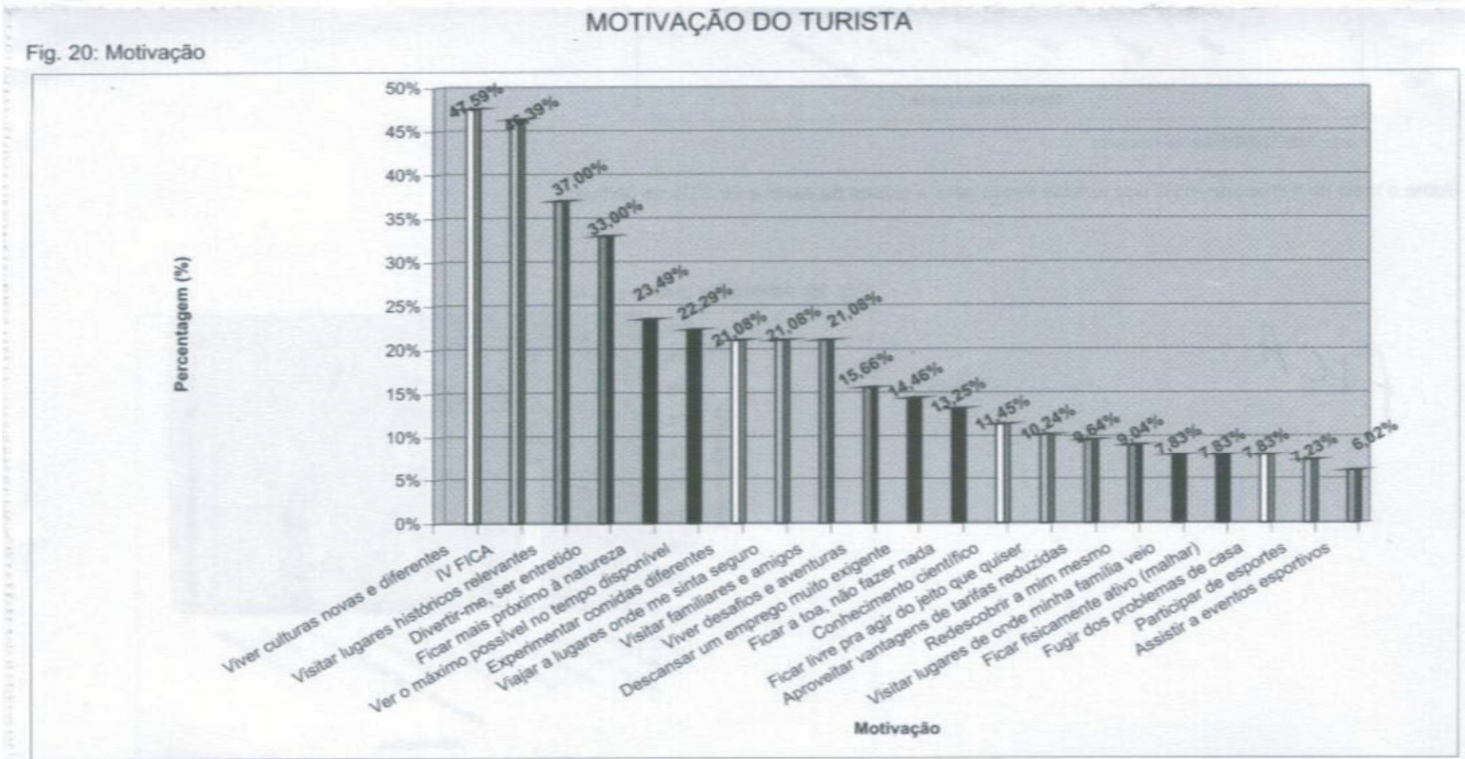

Fonte: AGETUR / Nücleo de Pesquise

Sobre motivaçăo, foram consideradas nas respostas apenas o item "muito importante". Vale ressaltar que esta questăo permitiu ao turista marcar várias opcōes. Verificou-se que $47,59 \%$ dos entrevistados foram à Cidade de Goiás para viverem culturas novas e diferentes, $46,39 \%$ para o IV FICA, $37 \%$ para visitarem lugares históricos relevantes e $33 \%$ para divertire-se e serem entratidos 
PERFIL DOS TURISTAS

Observa-se que em algumas questibes nầ foi atingido $100 \%$ das respostas

Fig. 1: Regiöes de origem

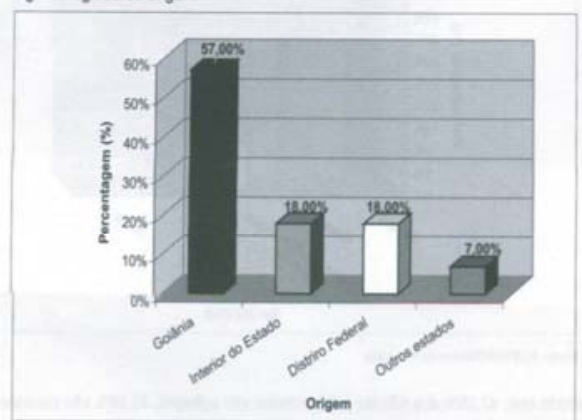

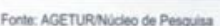

No que se refere à procedência, registrou-se que $57,00 \%$ dos turistas entrevistados provinham de Goiania, 18,00\% do Interior do Estado, $18,00 \%$ do Distrito Federal e 7,00\% de outros estados.

Fig. 9: Renda pessoal

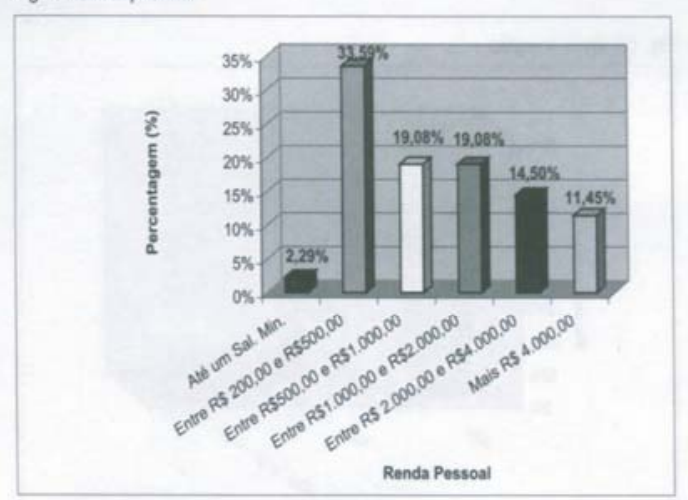

Fonte: AGETURNúdeo de Pesquisa

Dos turistas entrevistados, $33,59 \%$ têm renda pessoal entre RS 200,00 e RS $500,00,19,08 \%$ têm renda entre RS 500,00 e RS $1.000,00$ e entre RS $1.000,00$ e RS $2.000,00$ cada, $14,50 \%$ têm renda entre R\$ $2.000,00$ e R\$ $4.000,00$ e $11,45 \%$ têm renda acima de R\$ 4.000 .

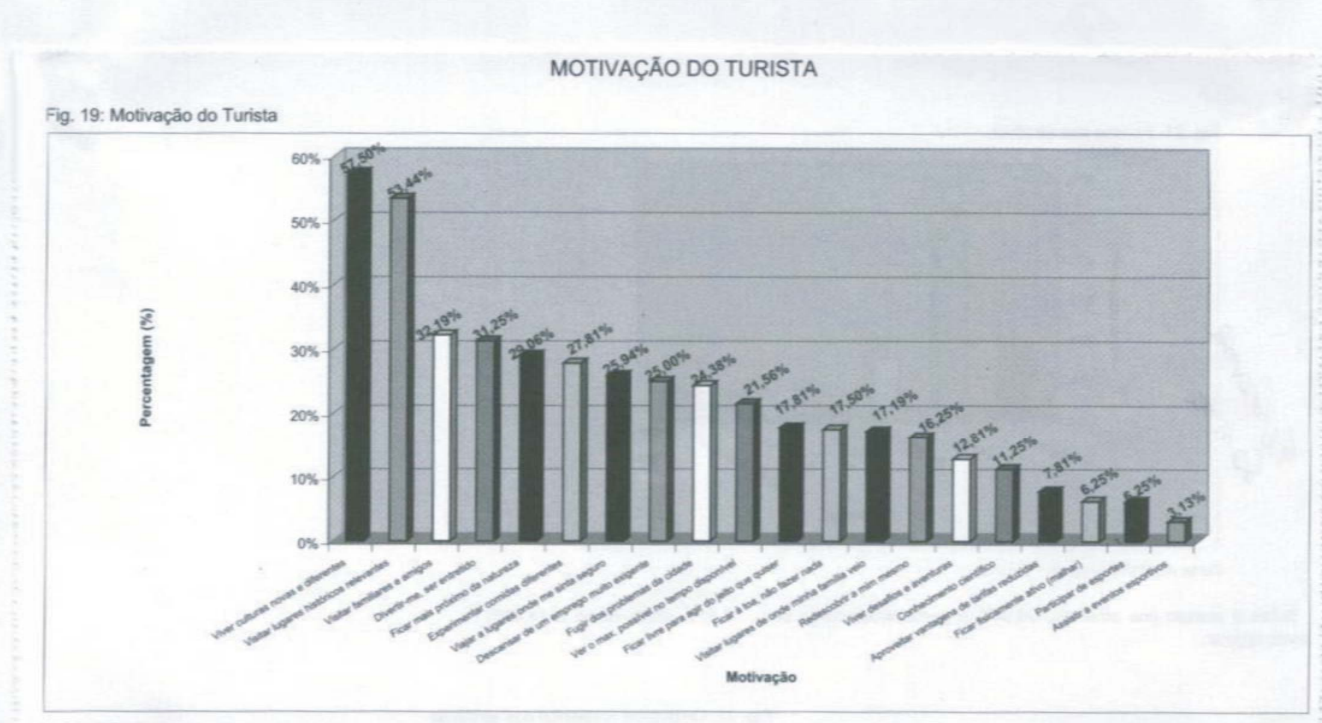

Fonte: AGETUR/ Nǘceo de Pesquisa

Sobre a motivaçăo foram consideradas nas respostas apenas o item "muito importante". Vale ressaltar que esta questão permitiu ao turista marcar várias opçés. Dos turistas entrevistados, $57,50 \%$ foram à Cidade de Goís para viver culturas novas e diferentes, $53,44 \%$ foram visitar lugares históricos relevantes. 3. $19 \%$ foram visitar familiares e amiaos e $31.25 \%$ foram divertir-se e serem entretidos. 
Gráficos dos questionários aplicados com os moradores da Cidade de Goiás

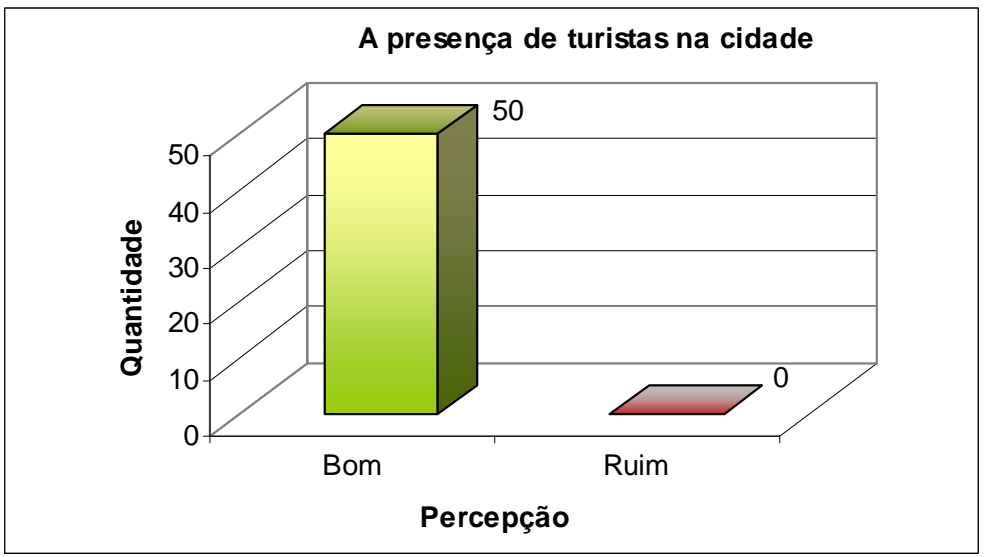

Fonte: Questionário aplicado na Cidade de Goiás em 2004.

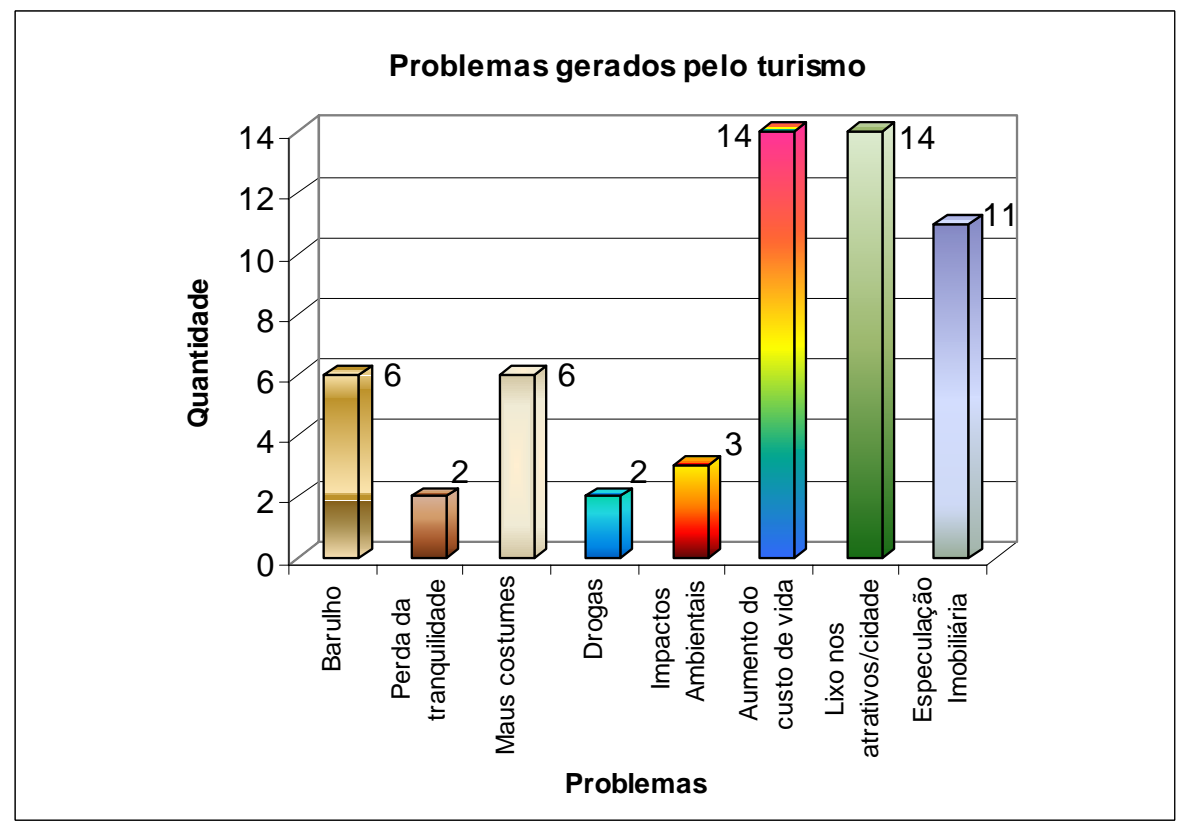

Fonte: Questionário aplicado na Cidade de Goiás em 2004.

Obs: Esta questão permitiu ao entrevistado marcar várias opções.

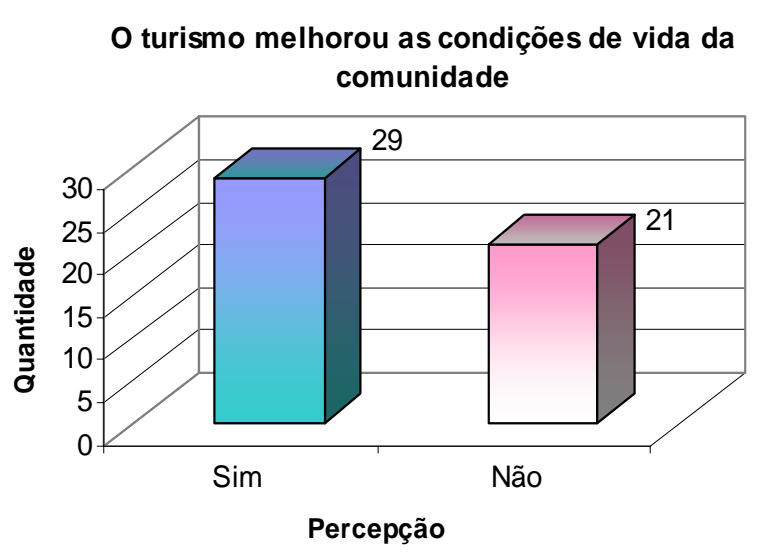

Fonte: Questionário aplicado na Cidade de Goiás em 2004. 
Gráficos dos questionários aplicados com os moradores da Cidade de Goiás

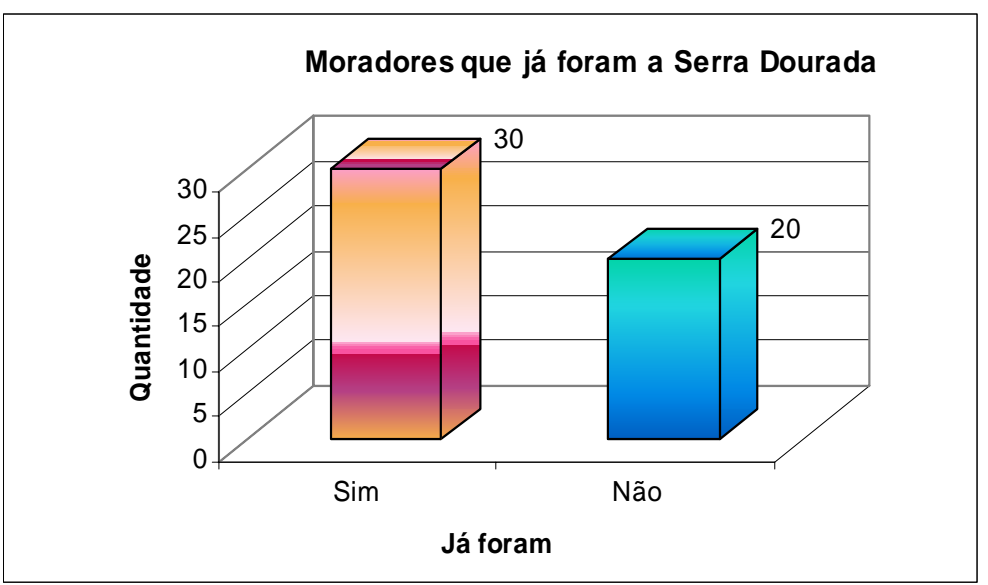

Fonte: Questionário aplicado na Cidade de Goiás em 2004.

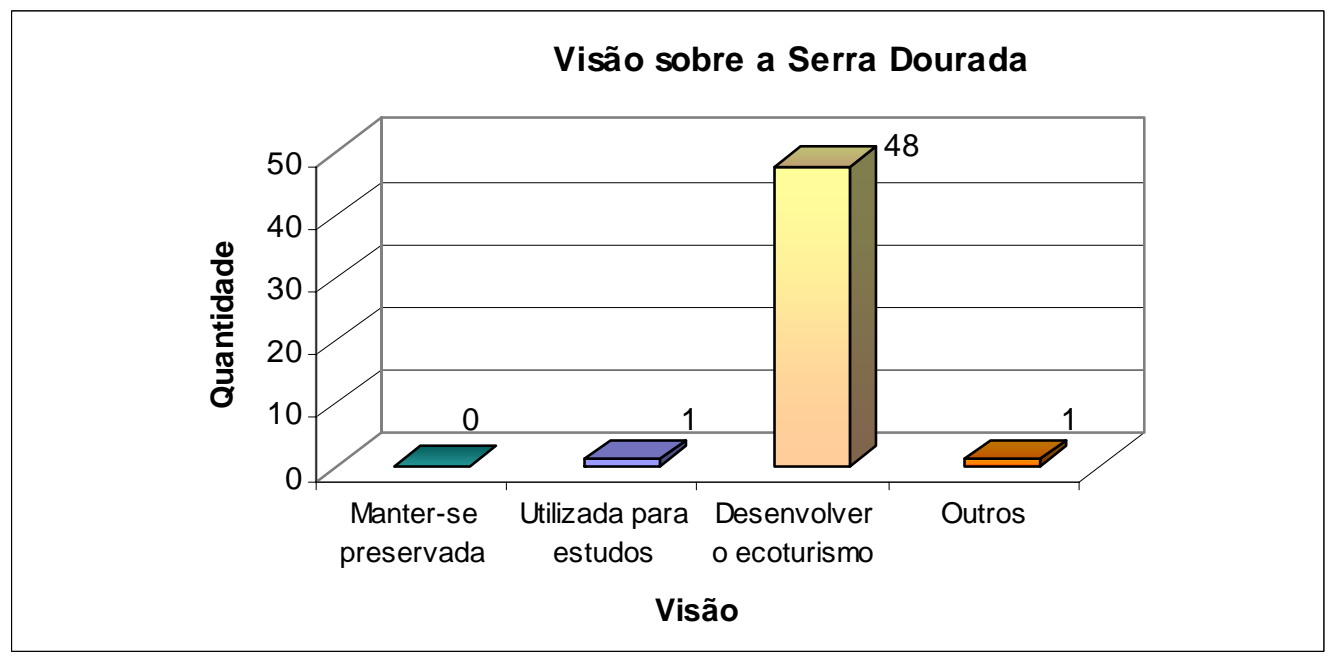

Fonte: Questionário aplicado na Cidade de Goiás em 2004.

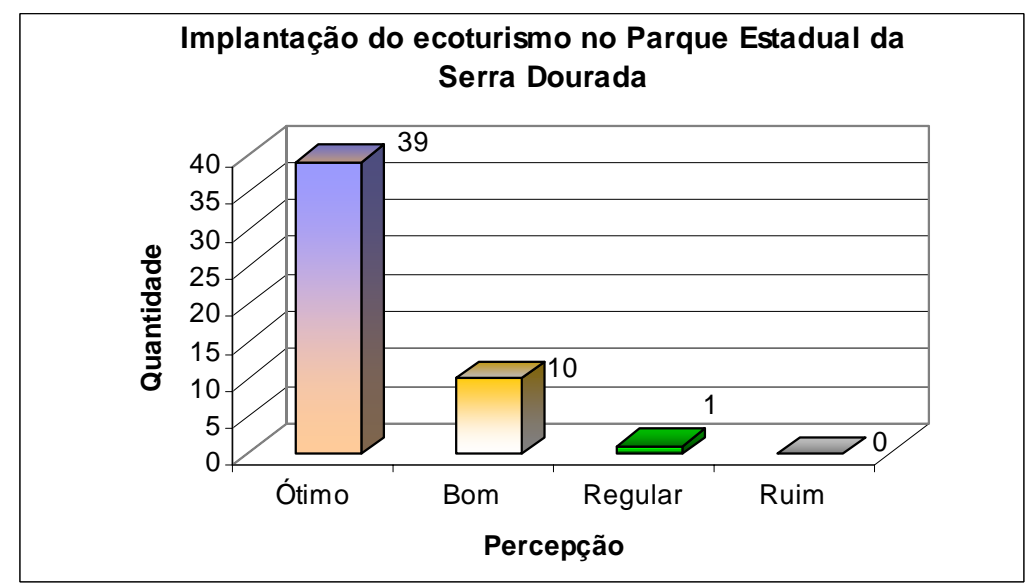

Fonte: Questionário aplicado na Cidade de Goiás em 2004. 
Gráficos dos questionários aplicados com os moradores da Cidade de Goiás
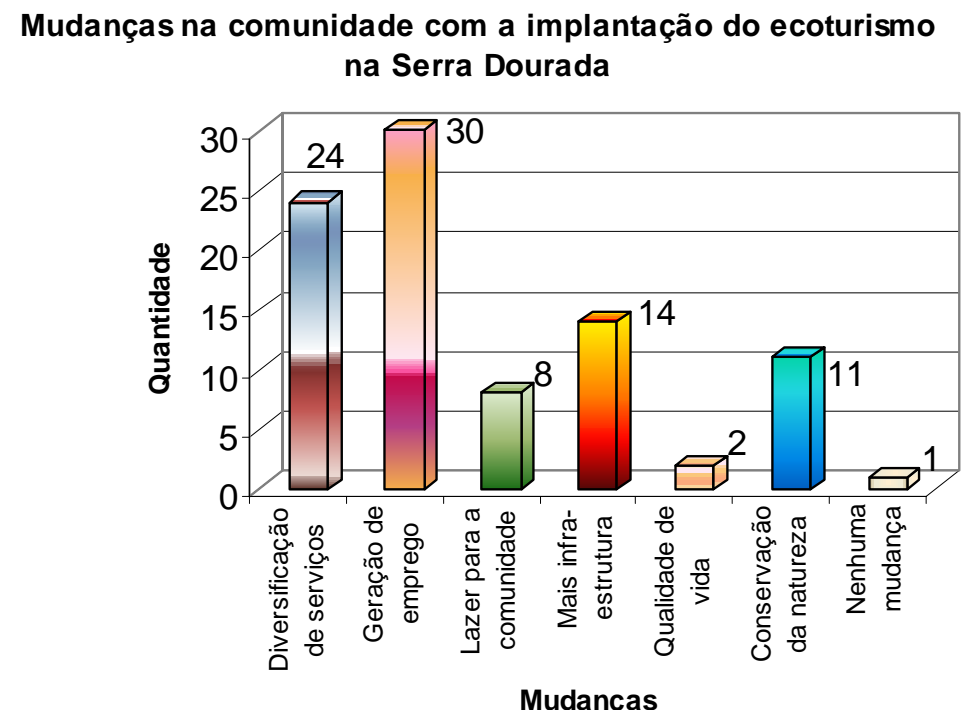

Fonte: Questionário aplicado na Cidade de Goiás em 2004.

Obs: Esta questão permitiu ao entrevistado marcar várias opções

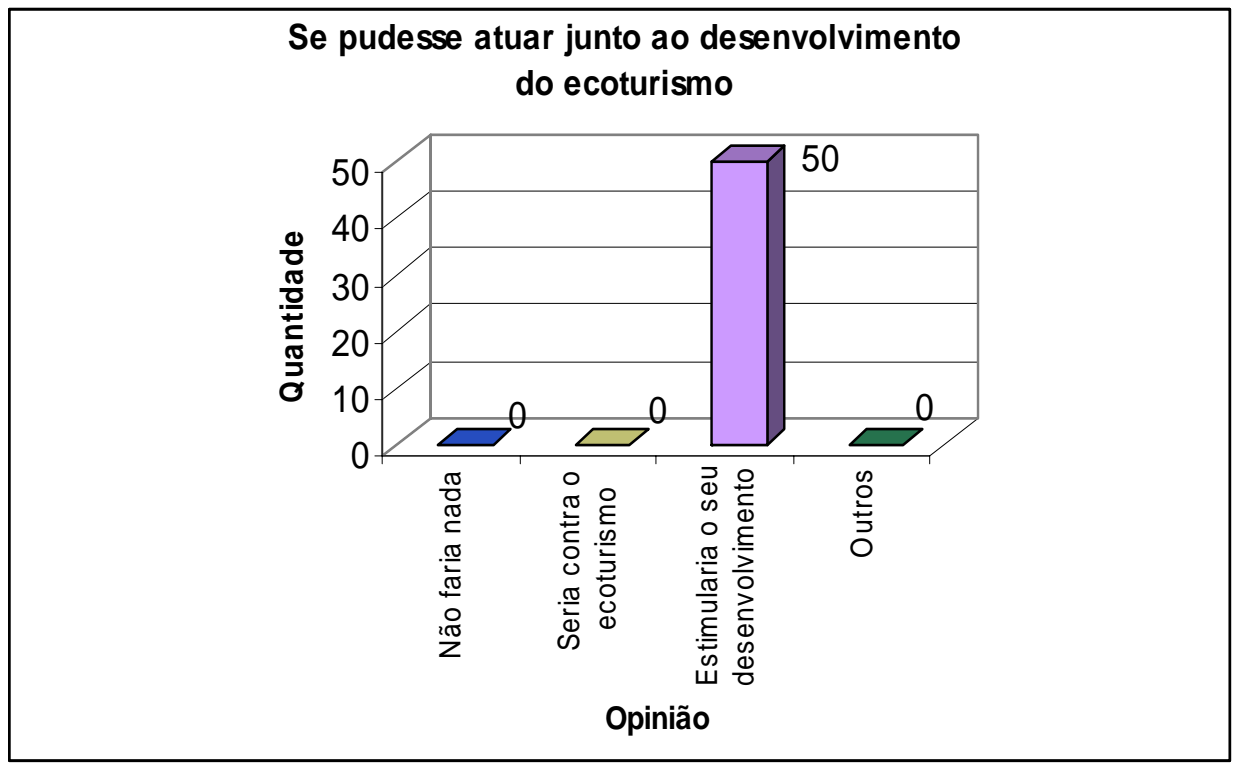

Fonte: Questionário aplicado na Cidade de Goiás em 2004. 
Gráficos dos questionários aplicados com turistas no Carnaval - 21 a 23/02/04

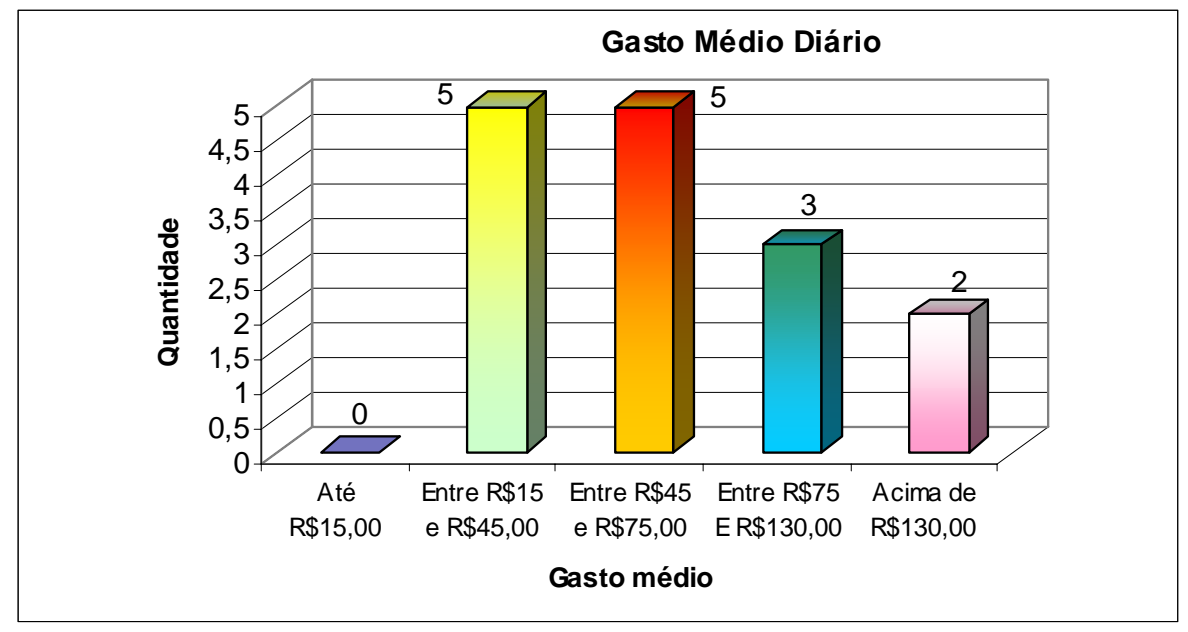

Fonte: Questionário aplicado na Cidade de Goiás em 2004.

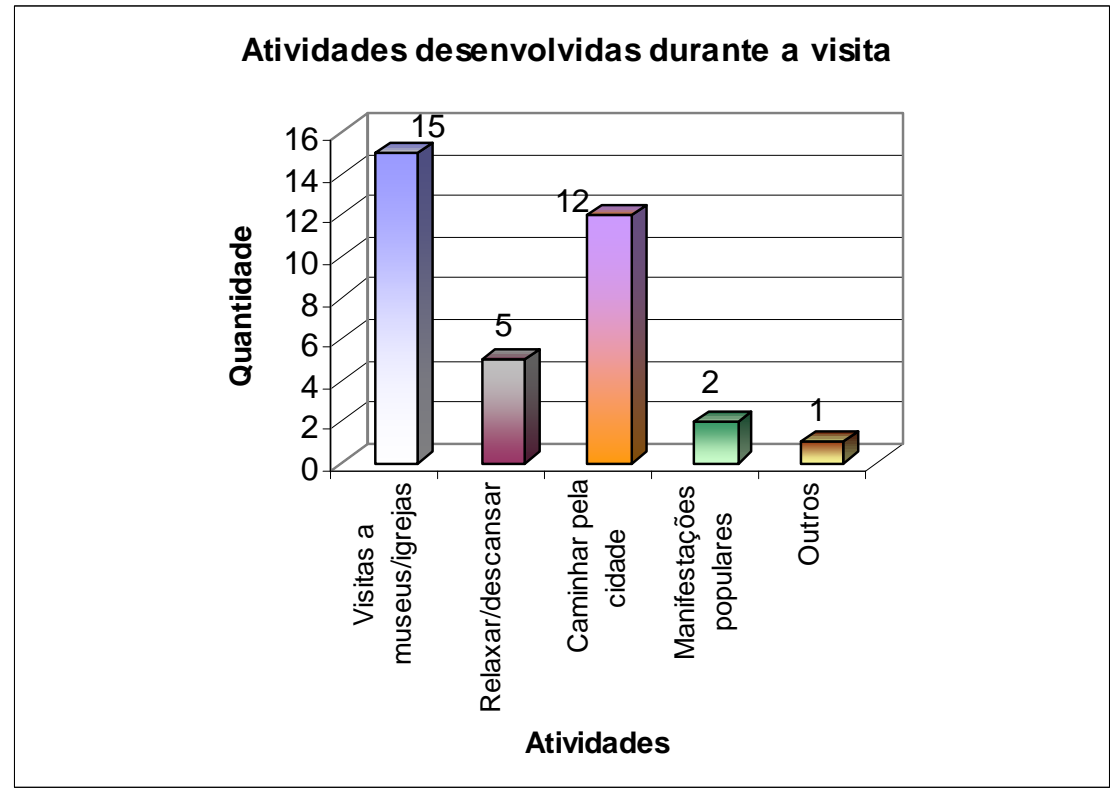

Fonte: Questionário aplicado na Cidade de Goiás em 2004.

Obs: Esta questão permitiu ao entrevistado marcar várias opções.

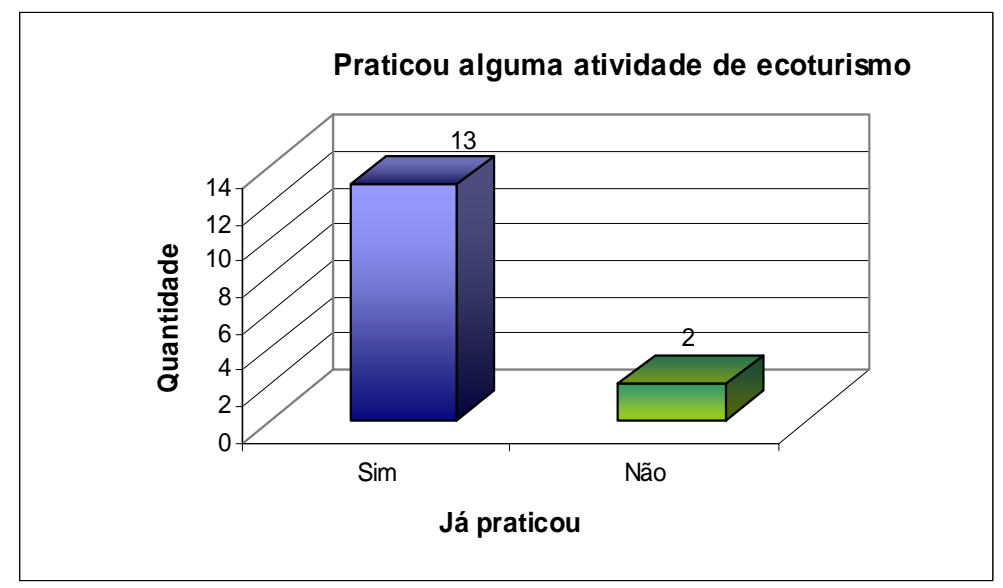

Fonte: Questionário aplicado na Cidade de Goiás em 2004. 
Gráficos dos questionários aplicados com turistas no Carnaval - 21 a 23/02/04

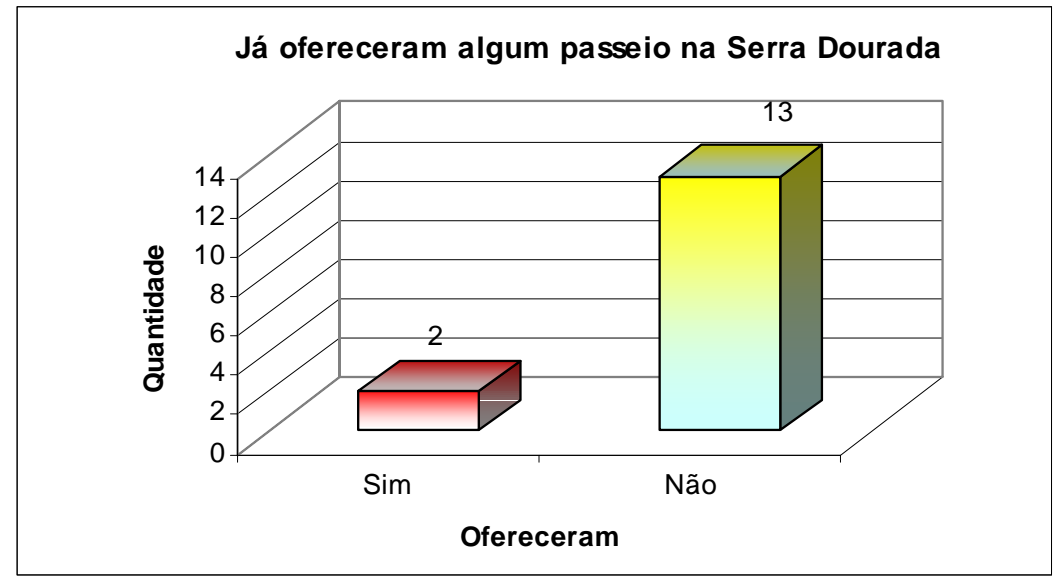

Fonte: Questionário aplicado na Cidade de Goiás em 2004.

Ecoturismo sendo realizado dentro de uma Unidade de Conservação - UC

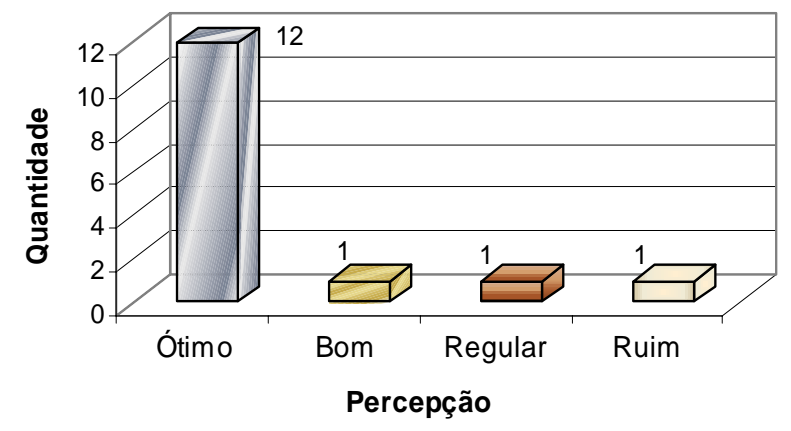

Fonte: Questionário aplicado na Cidade de Goiás em 2004. 
Gráficos dos questionários aplicados com turistas no Carnaval - 21 a 23/02/04

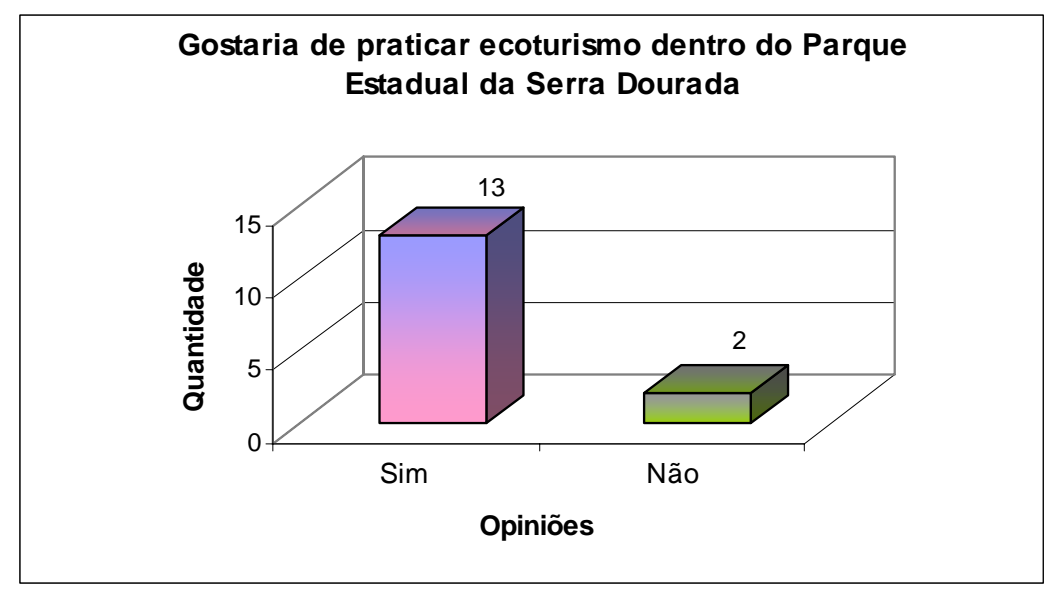

Fonte: Questionário aplicado na Cidade de Goiás em 2004.

Atividades que gostaria de fazer no Parque Estadual da Serra Dourada

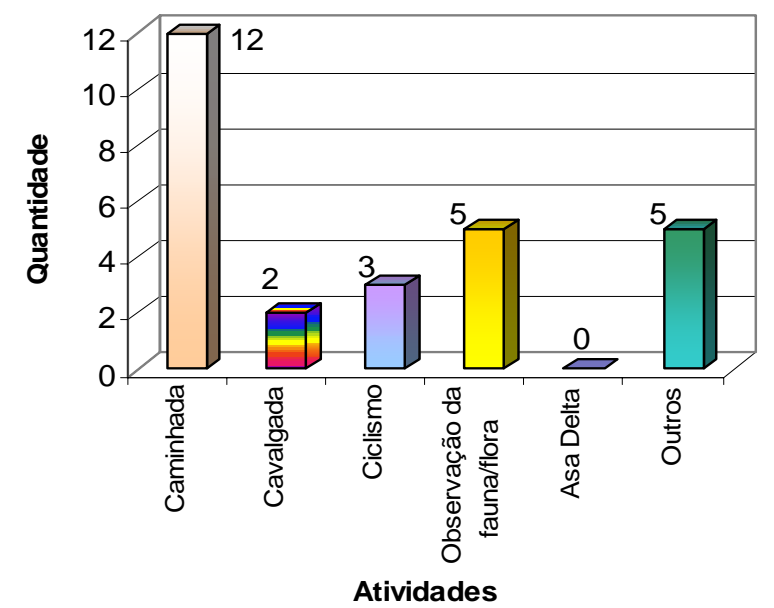

Fonte: Questionário aplicado na Cidade de Goiás em 2004.

Obs: Esta questão permitiu ao entrevistado marcar várias opções. 
Gráficos dos questionários aplicados com turistas na Semana Santa - 09 e 10/04/04

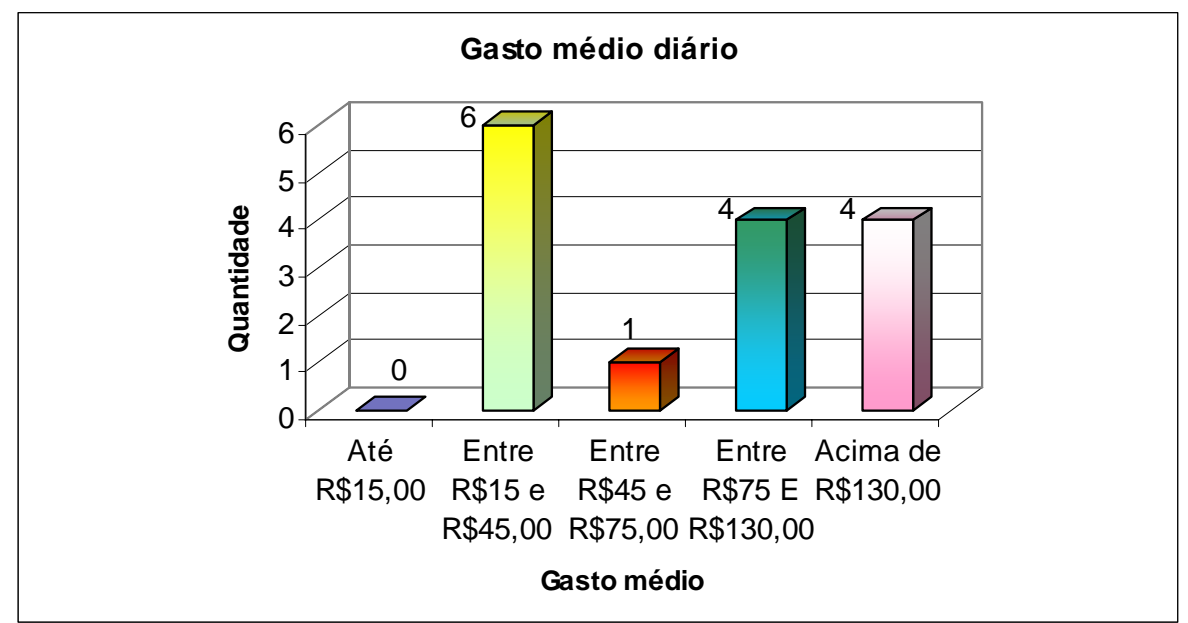

Fonte: Questionário aplicado na Cidade de Goiás em 2004.

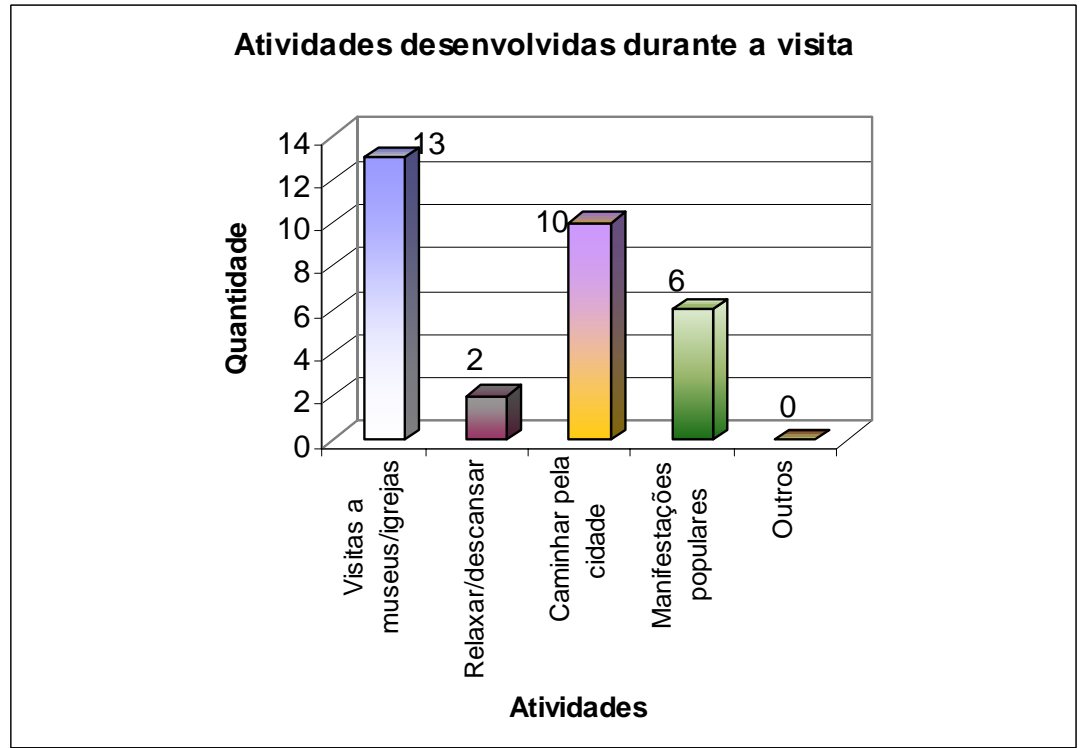

Fonte: Questionário aplicado na Cidade de Goiás em 2004.

Obs: Esta questão permitiu ao entrevistado marcar várias opções.

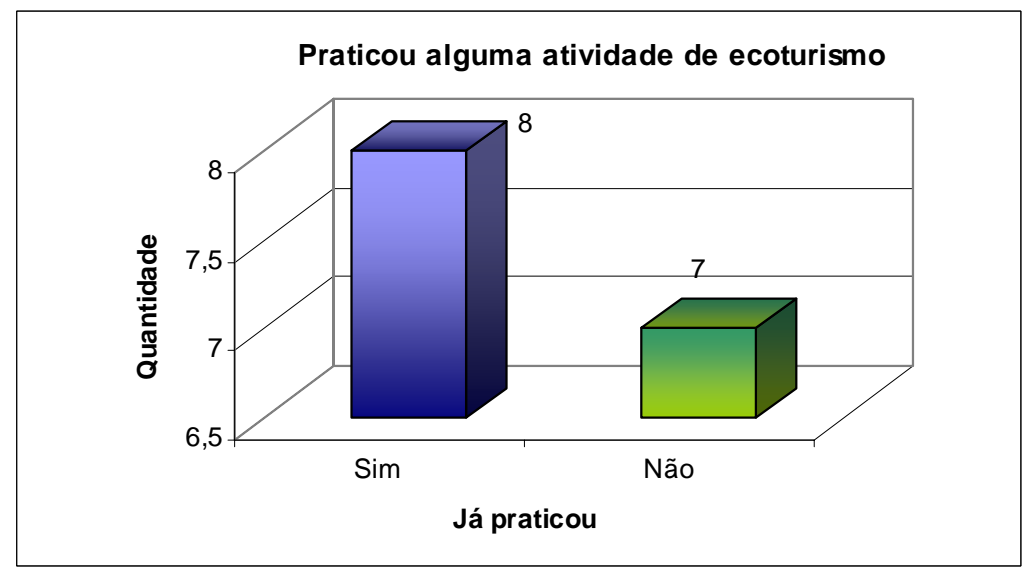

Fonte: Questionário aplicado na Cidade de Goiás em 2004. 
Gráficos dos questionários aplicados com turistas na Semana Santa - 09 e 10/04/04

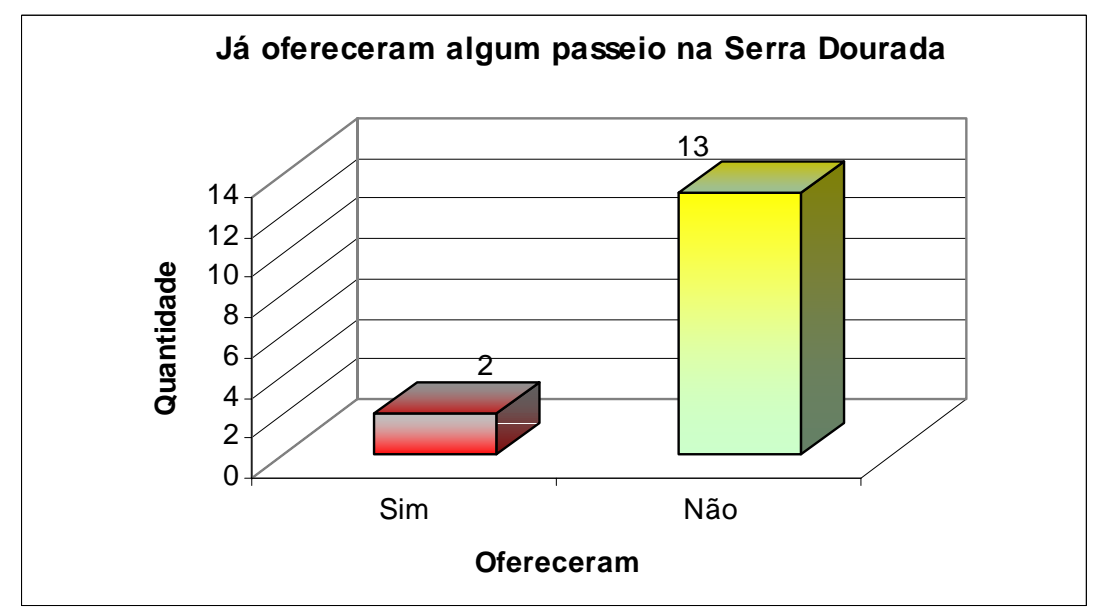

Fonte: Questionário aplicado na Cidade de Goiás em 2004.

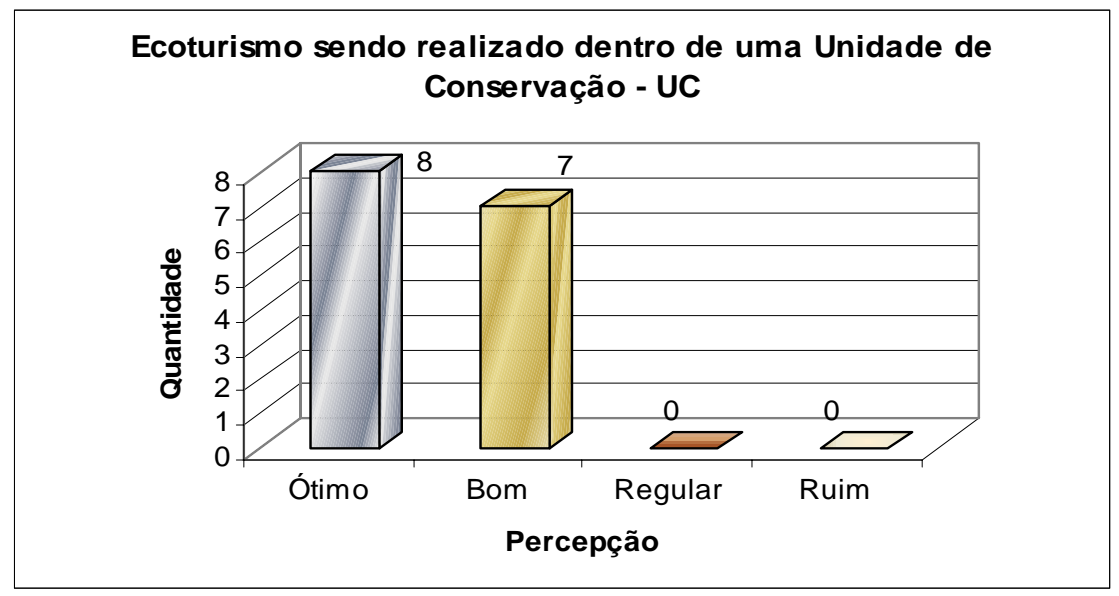

Fonte: Questionário aplicado na Cidade de Goiás em 2004. 
Gráficos dos questionários aplicados com turistas na Semana Santa - 09 e 10/04/04

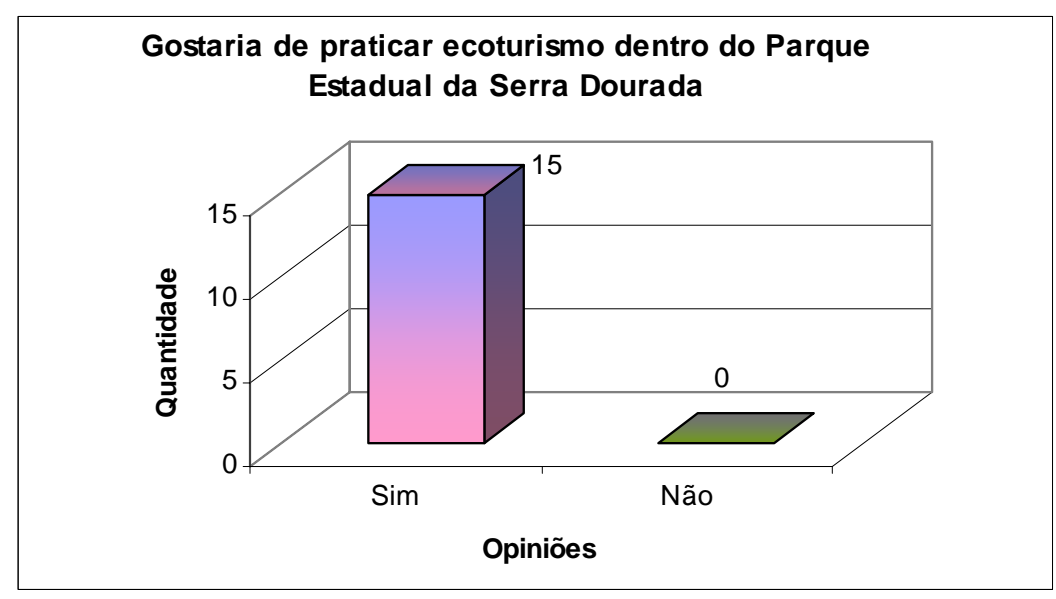

Fonte: Questionário aplicado na Cidade de Goiás em 2004.

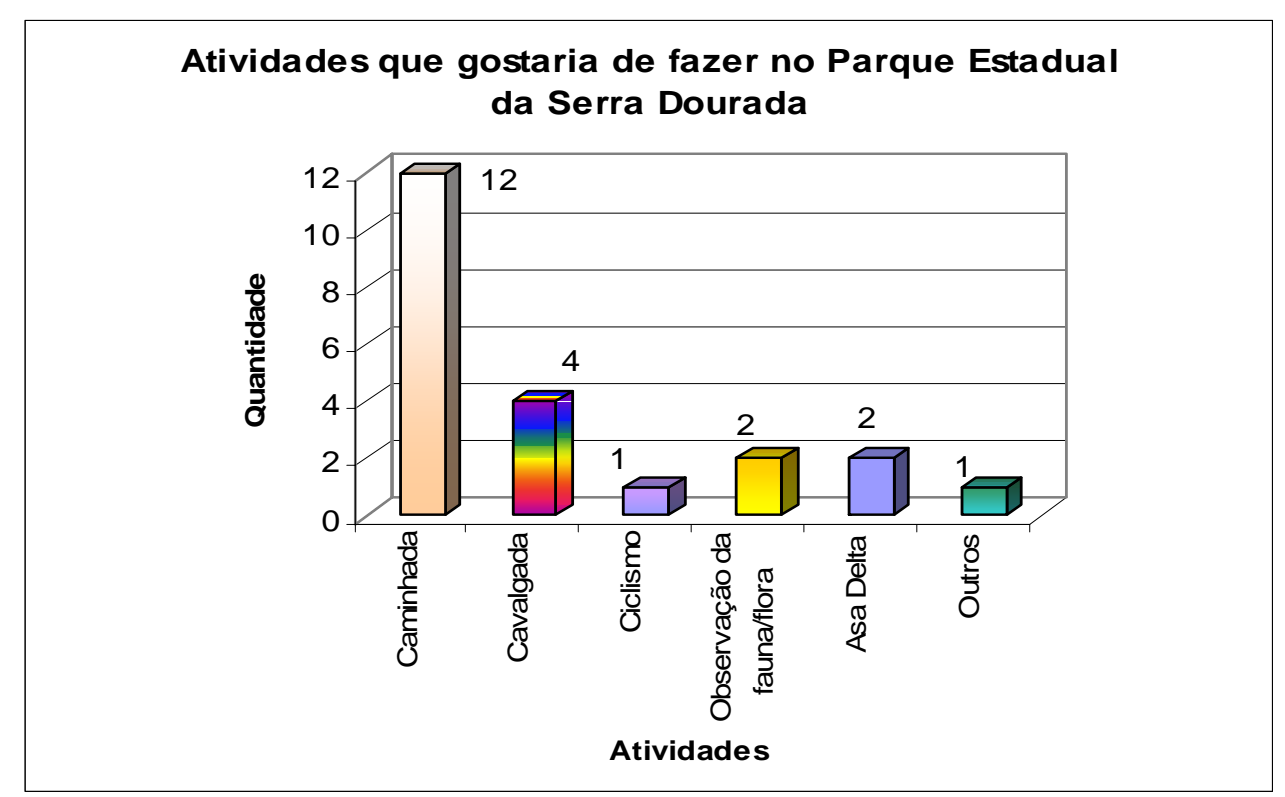

Fonte: Questionário aplicado na Cidade de Goiás em 2004.

Obs: Esta questão permitiu ao entrevistado marcar várias opções. 
Gráficos dos questionários aplicados com turistas em um final de semana - 15 e 16/05/04

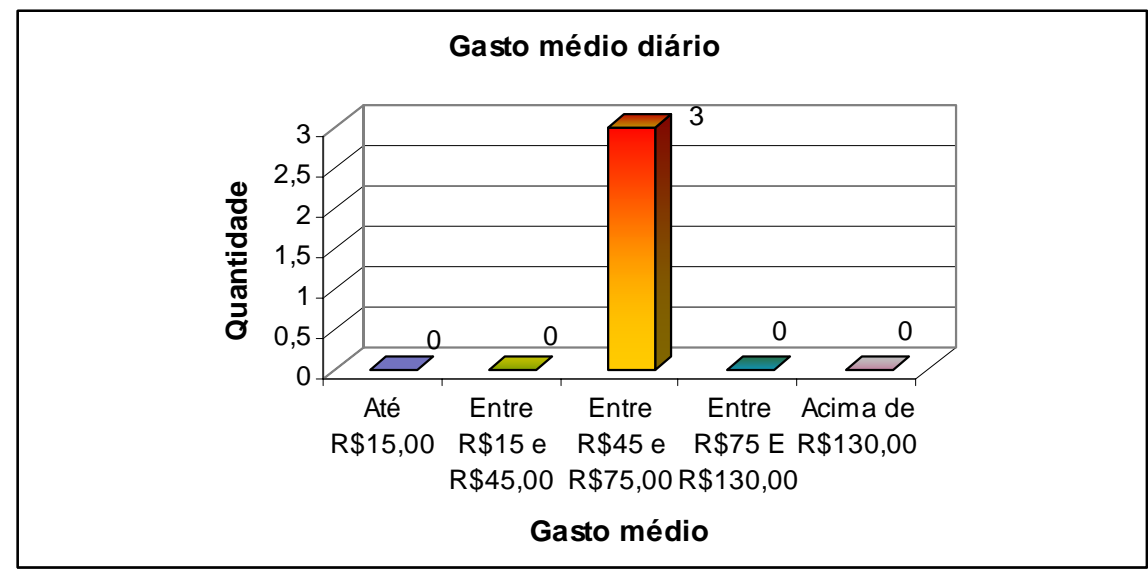

Fonte: Questionário aplicado na Cidade de Goiás em 2004.

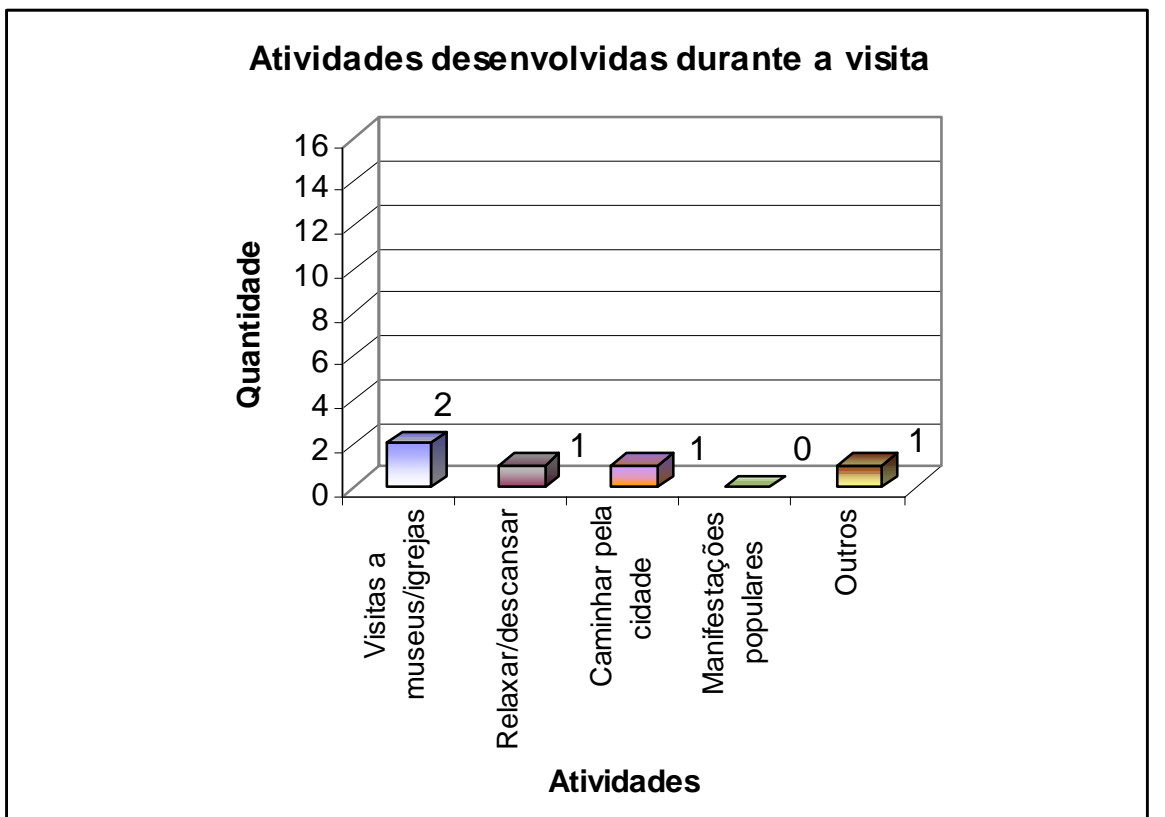

Fonte: Questionário aplicado na Cidade de Goiás em 2004.

Obs: Esta questão permitiu ao entrevistado marcar várias opções.

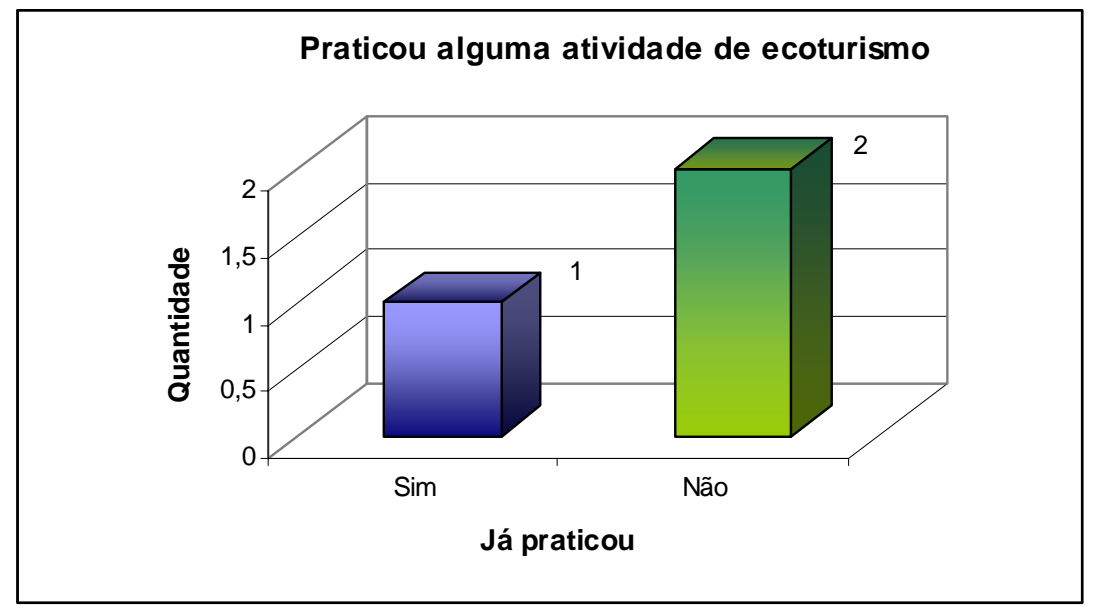

Fonte: Questionário aplicado na Cidade de Goiás em 2004. 
Gráficos dos questionários aplicados com turistas em um final de semana - 15 e 16/05/04

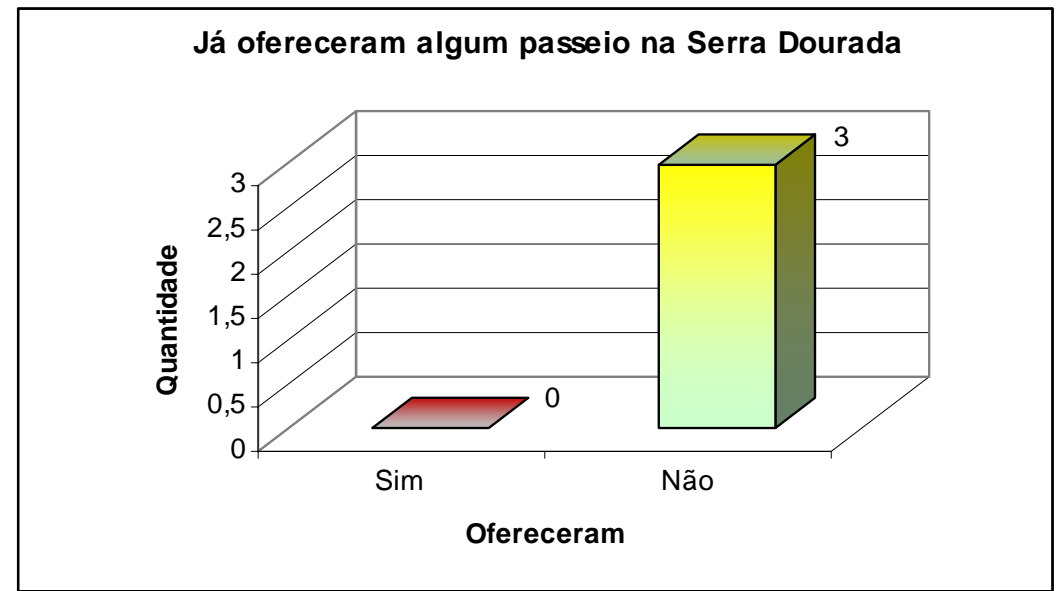

Fonte: Questionário aplicado na Cidade de Goiás em 2004.

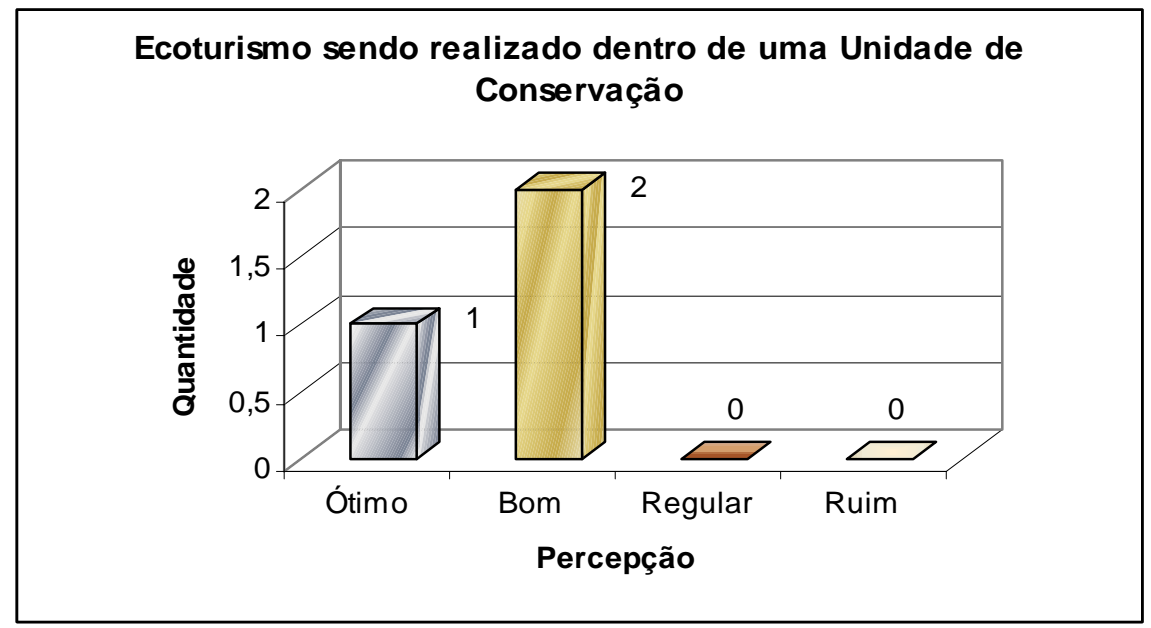

Fonte: Questionário aplicado na Cidade de Goiás em 2004. 
Gráficos dos questionários aplicados com turistas em um final de semana - 15 e 16/05/04

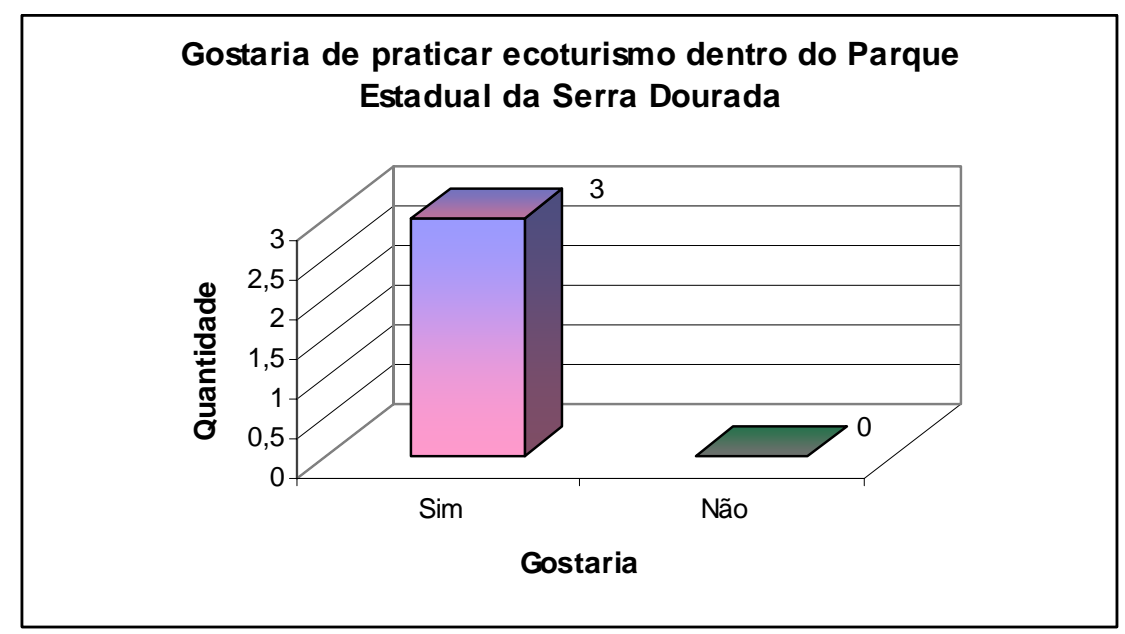

Fonte: Questionário aplicado na Cidade de Goiás em 2004.

Atividades que gostaria de fazer no Parque Estadual da Serra Dourada

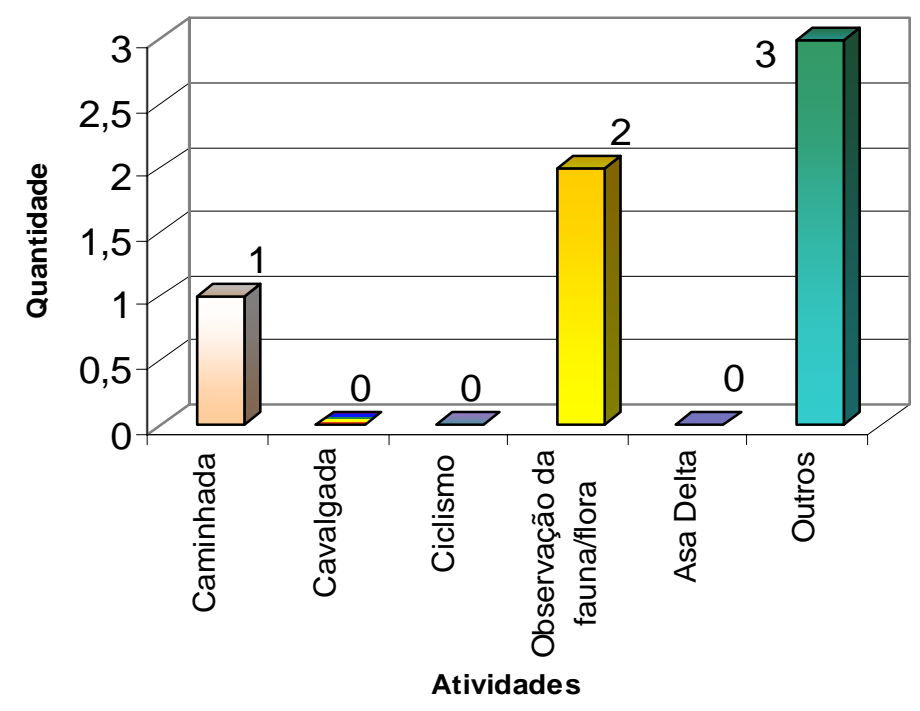

Fonte: Questionário aplicado na Cidade de Goiás em 2004.

Obs: Esta questão permitiu os entrevistados marcar várias opções. 
Gráficos dos questionários aplicados com turistas no FICA - 05 e 06/06/04

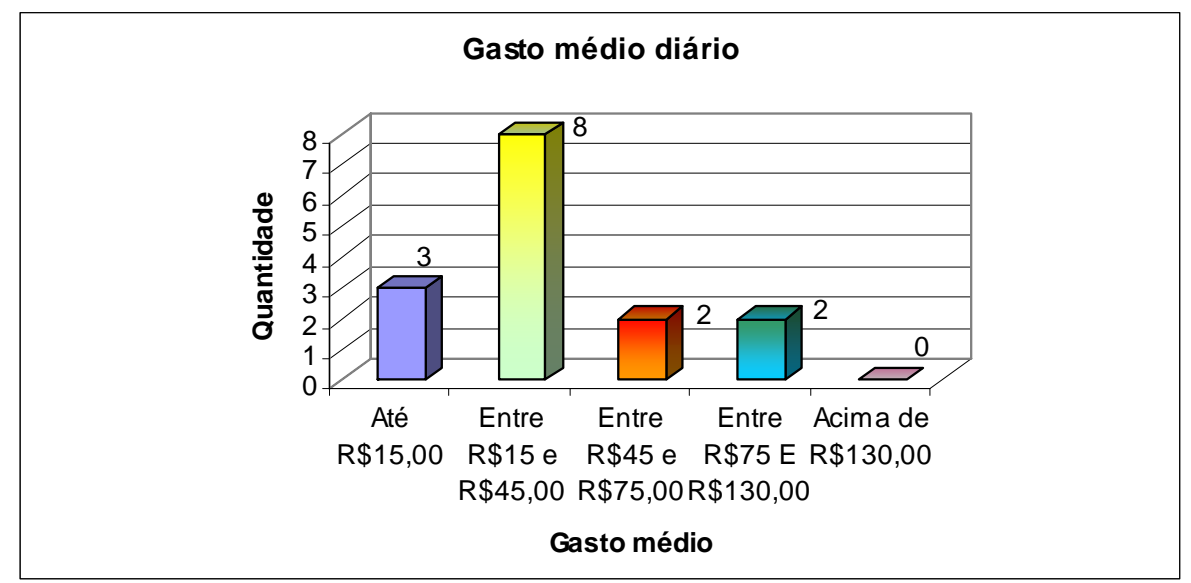

Fonte: Questionário aplicado na Cidade de Goiás em 2004.

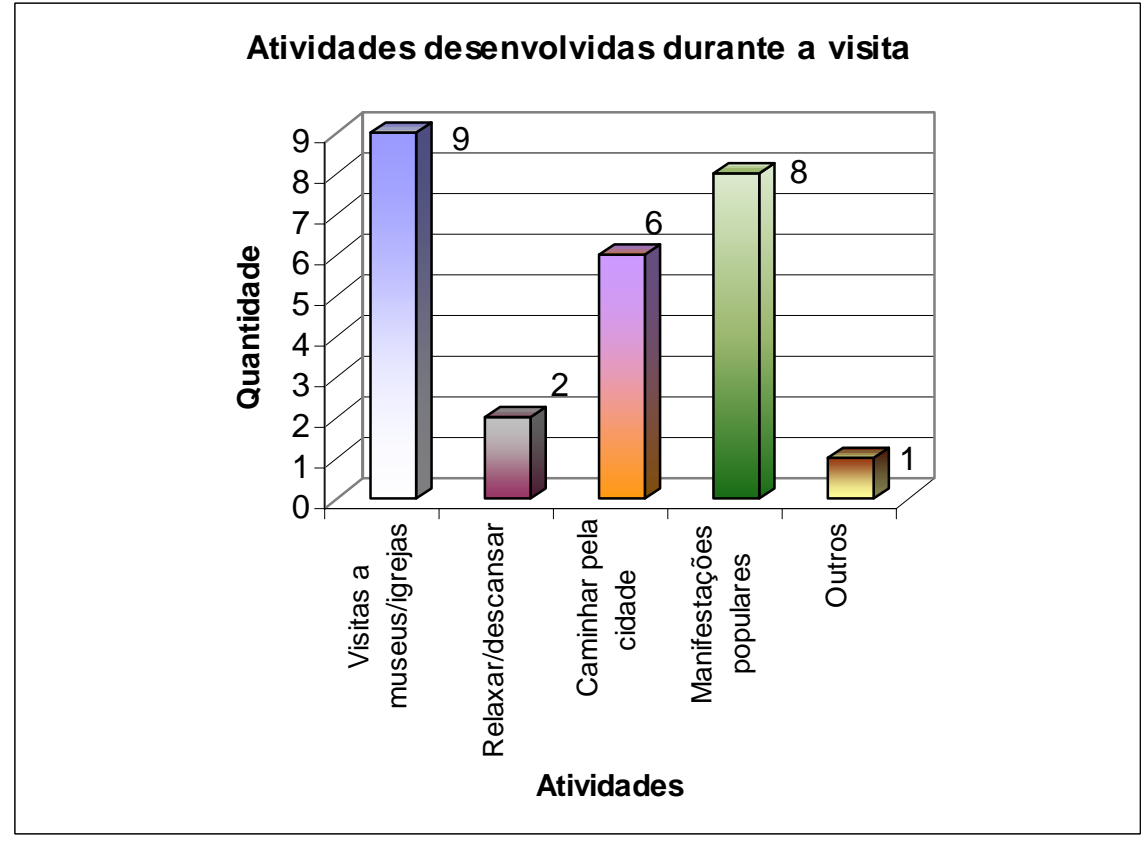

Fonte: Questionário aplicado na Cidade de Goiás em 2004.

Obs: Esta questão permitiu aos entrevistados marcar várias opções.

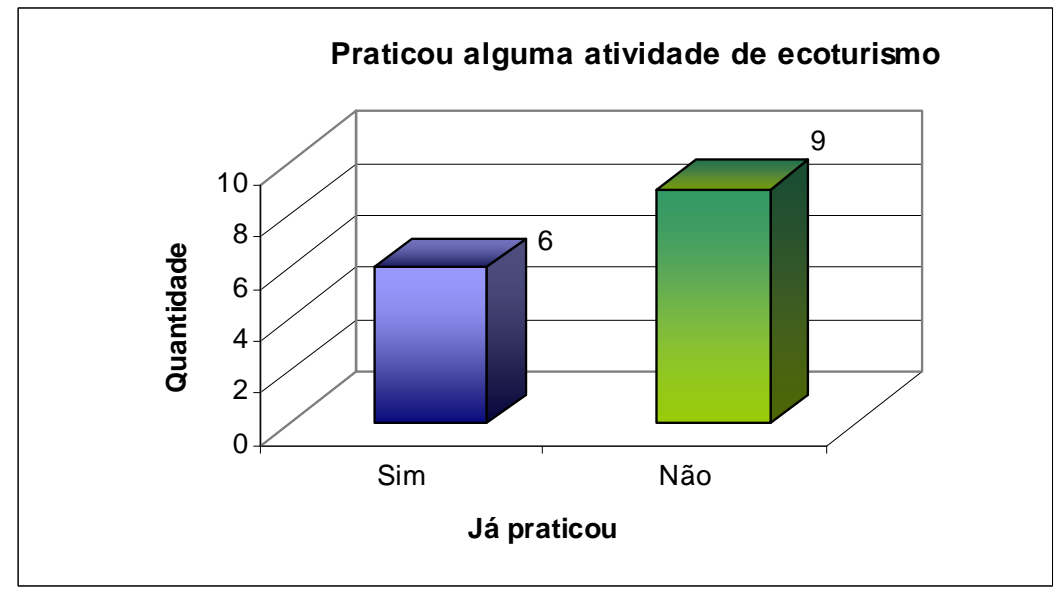

Fonte: Questionário aplicado na Cidade de Goiás em 2004. 
Gráficos dos questionários aplicados com turistas no FICA - 05 e 06/06/04

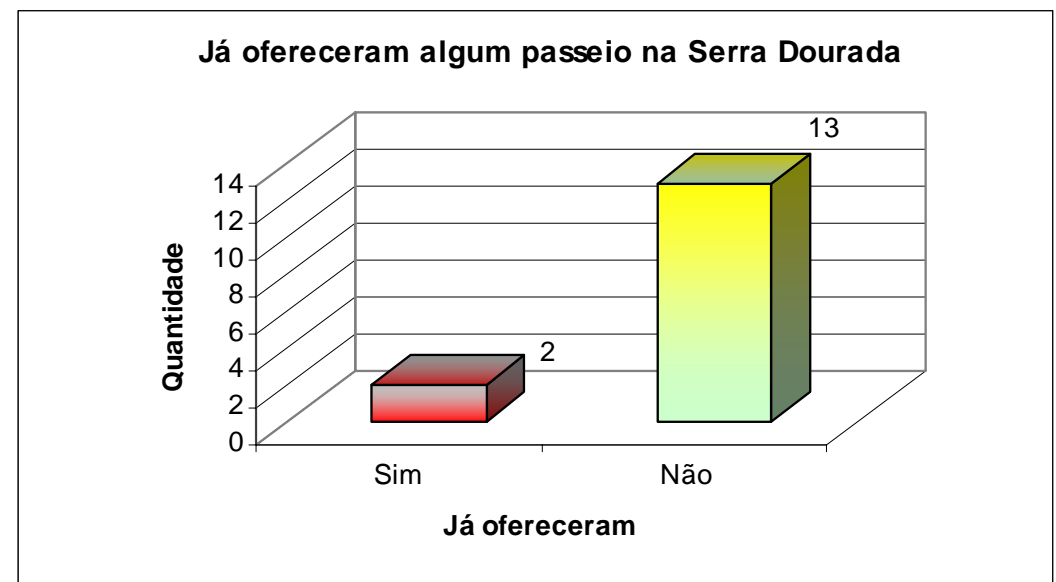

Fonte: Questionário aplicado na Cidade de Goiás em 2004.

Ecoturismo sendo realizado dentro de uma Unidade de Conservação - UC

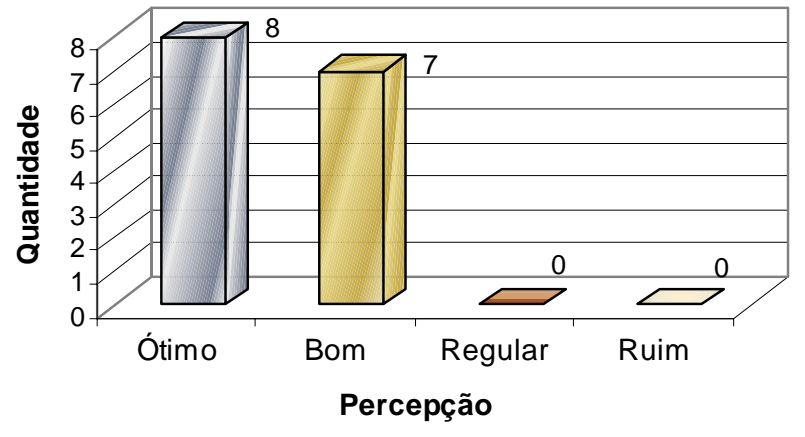

Fonte: Questionário aplicado na Cidade de Goiás em 2004. 
Gráficos dos questionários aplicados com turistas no FICA - 05 e 06/06/04

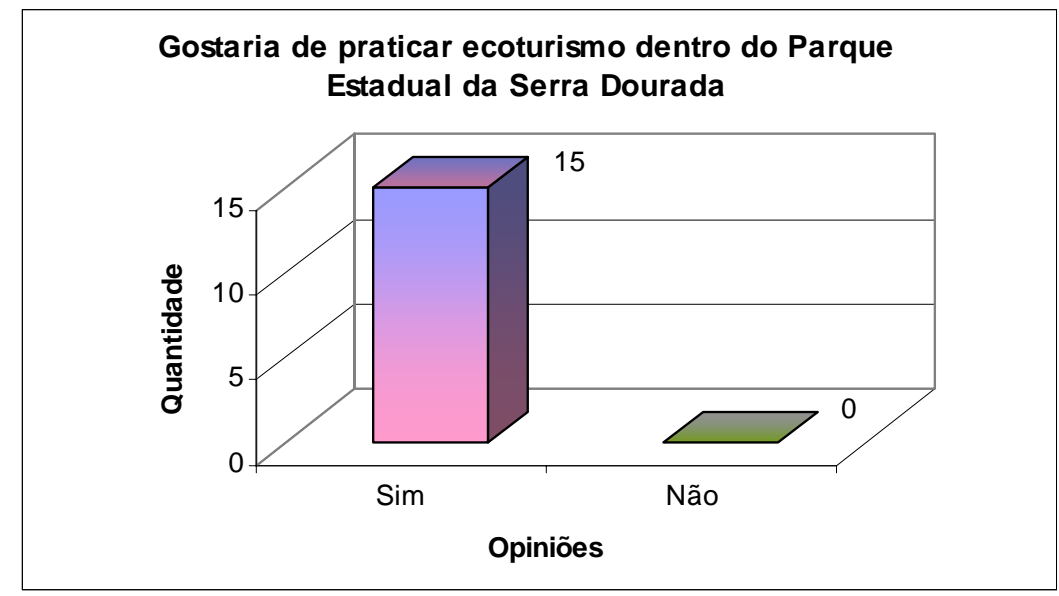

Fonte: Questionário aplicado na Cidade de Goiás em 2004.

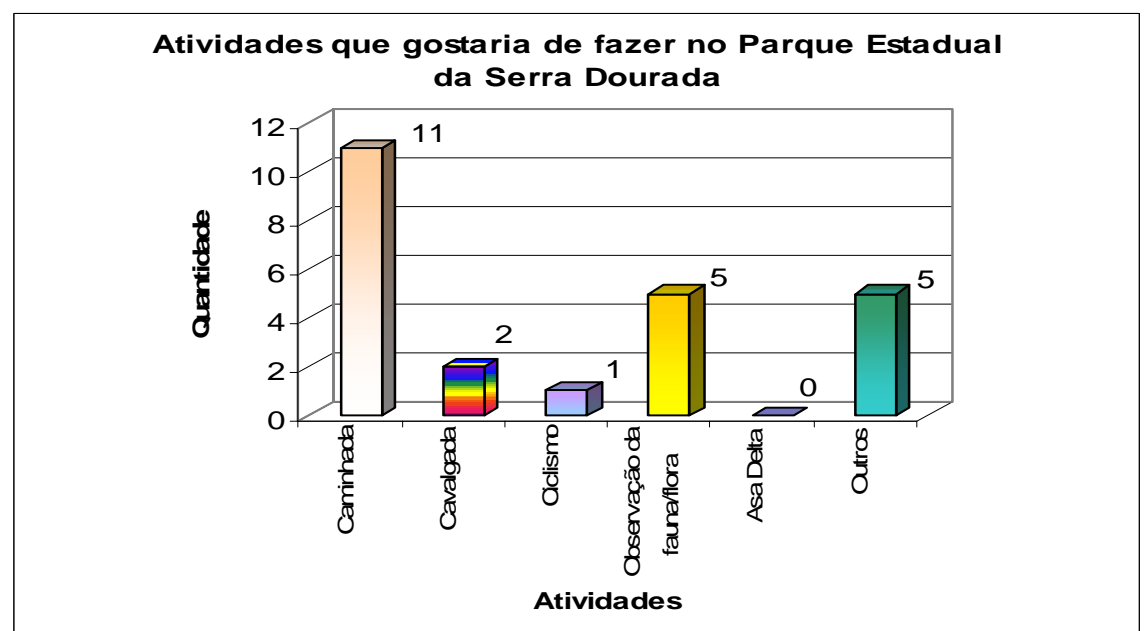

Fonte: Questionário aplicado na Cidade de Goiás em 2004.

Obs: Esta questão permitiu aos entrevistados marcar várias opções. 
Com relação aos dados coletados junto aos moradores da Cidade de Goiás, verifica-se em um primeiro momento, que dos (50) entrevistados, todos sem exceção, consideram bom ter a presença de turistas na cidade, pois o turismo aumenta a venda no comércio, fortalece a história, o patrimônio local e valoriza mais a cidade. Alguns dos moradores vêm como vocação essa atividade para a Cidade de Goiás, pois muitos sobrevivem da mesma.

Entretanto, mesmo considerando fundamental o turismo para o município, os moradores ainda apontam alguns problemas que podem ser gerados por essa atividade. Segundo a pesquisa, (14) dos (50) entrevistados consideraram o aumento do custo de vida e o lixo nos atrativos/cidade como sendo os principais impactos negativos, seguidos pela especulação imobiliária (11), barulho (6) e maus costumes (6), que podem ser observados no gráfico.

O turismo, na opinião de (29) moradores, já melhorou as condições de vida da comunidade, enquanto (21) pessoas ainda não acreditam nesse fato. Constata-se que um número grande de moradores nunca foi a Serra Dourada (20 pessoas das 50 entrevistadas), e isso acaba demonstrando que nem os próprios habitantes locais conhecem os recursos naturais da região, que podem ser trabalhados, como forma de serem transformados em um produto ecoturístico.

Verificou-se também que (48) moradores afirmam ser importante desenvolver o ecoturismo no Parque Estadual da Serra Dourada e (39) acharam ótima a iniciativa de implantação do parque estadual. Com a implantação dessa atividade na Serra Dourada, a comunidade entende que a cidade mudaria de uma certa forma, isto porque, (30) pessoas acham que a mesma poderia gerar emprego, (24) acreditam que diversificaria os serviços, permitindo com isso, que os turistas fiquem mais dias na cidade, até porque, segundo a pesquisa da AGETUR, os visitante geralmente permanecem de 1 a 3 dias. Além disso, (14) pessoas sentem que o ecoturismo poderá trazer mais infra-estrutura para a cidade e (11), que essa atividade permitirá a conservação da natureza.

Apesar de não estar exemplificado sob a forma de gráfico nessa monografia, os moradores relataram algumas necessidades que consideram importantes para a prática do turismo local. Informaram-me da necessidade de maiores investimentos na cidade, tanto em 
relação ao poder público, quanto em relação à iniciativa privada, principalmente referindo-se a infra-estrutura local. Alguns moradores sentem também a necessidade de maior divulgação do município, bem como, da própria organização e conscientização do trade turístico local, passando até mesmo, pela maior capacitação dos moradores que trabalham nesse segmento de mercado. A grande maioria dos entrevistados queixou-se também da falta de empregos e oportunidades no município.

Todos os moradores pesquisados caso pudessem expressar seu posicionamento junto aos órgãos de desenvolvimento do ecoturismo, estimulariam iniciativas e ações, não se opondo a elaboração de mais esse eventual produto turístico. Portanto, por parte da comunidade, a implementação do ecoturismo no Parque Estadual da Serra Dourada é totalmente viável e necessária.

No que se refere aos dados coletados junto aos turistas que freqüentam a Cidade de Goiás observa-se que no Carnaval, o gasto médio diário por pessoa é entre $\mathrm{R} \$ 15,00$ e $\mathrm{R} \$$ 75,00 (10 pessoas das 15 entrevistadas), entre $\mathrm{R} \$ 75,00$ e acima de $\mathrm{R} \$ 130,00$ na Semana Santa (8 pessoas das 15 entrevistadas), entre $\mathrm{R} \$ 45,00$ e $\mathrm{R} \$ 75,00$ em um final de semana comum (somente 3 pessoas entrevistadas) e entre $\mathrm{R} \$ 15,00$ e $\mathrm{R} \$ 45,00$ (8 pessoas das 15 entrevistadas), como pode ser constatado no gráfico.

As principais atividades desenvolvidas pelos turistas no município, tanto no Carnaval (15 pessoas), na Semana Santa (13 pessoas), no final de semana comum (2 pessoas) e no FICA (9 pessoas), é a visita a museus/igrejas. Por outro lado, caminhar pela cidade aparece em segundo lugar nas pesquisas em todos esses períodos, o que de uma certa forma, é favorável para o desenvolvimento do ecoturismo na região, pois muitas pessoas ficam andando pela cidade simplesmente por não ter outra opção de lazer, por isso mesmo, o ecoturismo é atividade ideal para suprir essa necessidade.

Também é fator complementar a esse dado a pesquisa da AGETUR, visto que, segundo essa fonte, a grande maioria das pessoas desloca-se para o município no intuito de viver culturas novas e diferentes, mas sendo também bastante significativo a porcentagem de pessoas interessadas em ficar mais próximas da natureza, como pode ser detectado no gráfico. 
No Carnaval, das 15 pessoas entrevistadas (13) já praticaram alguma atividade de ecoturismo, na Semana Santa (8), no final de semana (1) das 3 pessoas entrevistadas e no FICA (6) das 15 entrevistadas. Esse fato nos revela, portanto a demanda que existe na cidade para os praticantes interessados no turismo na natureza. Outra informação colhida, que se torna bastante interessante para a realização dessa monografia, é o fato de que já sabendo que alguns guias levam turistas para a Serra Dourada, mesmo sem a real estruturação do parque, tanto no Carnaval, na Semana Santa e no FICA (39) pessoas das 45 entrevistadas disseram não ter recebido nenhuma oferta para estarem conhecendo a serra, bem como, no final de semana os 3 visitantes entrevistados também não receberam nenhuma proposta ou tiveram conhecimento dessa atividade no município.

É quase unanimidade entre os turistas da cidade considerarem ótimo ou bom a realização do ecoturismo dentro de uma unidade de conservação, sendo no Carnaval (13) pessoas, na Semana Santa (15), no final de semana (3) e no FICA (15). Dos 15 entrevistados no Carnaval (13) disseram que gostaria de praticar o ecoturismo dentro do Parque Estadual da Serra Dourada, na Semana Santa (15), no final de semana (3) e no FICA (15). E, dentre as atividades que os turistas gostariam de fazer dentro do parque destaca-se a caminhada e a observação da fauna/flora local.

Como a pesquisa do perfil do visitante realizada pela AGETUR mostra que um número bastante significativo de pessoas já havia estado na região, parece extremamente importante diversificar os serviços oferecidos aos turistas, para que estes, possam continuar viajando para a mesma região, por isso, a implantação do ecoturismo na Serra Dourada é totalmente viável de acordo com o que foi observado nos questionários aplicados na cidade. 


\section{CAPÍTULO 9}

\section{SUGESTÕES E PROPOSTAS}

De início, é bom lembrar que a Serra Dourada é divisora de águas, pois de lá partem águas que alimentam três das importantes bacias hidrográficas do Brasil (Tocantins, Paraná e Araguaia). Essa área, como se pode constatar, e já falado anteriormente no capítulo 5, é importante porque tem um alto grau de endemismo, como por exemplo, o Papirus. Vale ressaltar também, que dentro da área do parque, vivem algumas espécies que são ameaçadas de extinção, além do que, essa região possui uma grande biodiversidade florística no que se refere a plantas frutíferas e medicinais, sendo que, a sua grande maioria faz parte da própria culinária goiana. São exemplos, o arroz com pequi, o empadão goiano que inclui a guariroba, os doces e licores que são produzidos com frutos nativos do cerrado, entre outros.

Os próprios recursos naturais, como os rios, as cachoeiras e as trilhas, são atrativos potenciais, e no caso da Cidade de Goiás, que já possui um patrimônio histórico e cultural que remonta toda a história do Estado, unindo então esses dois patrimônios, ou seja, tanto o histórico-cultural quanto o ambiental, pode-se trazer uma possibilidade de perspectiva de geração de emprego e renda e melhoria da qualidade de vida das pessoas do lugar. $\mathrm{Na}$ realidade, pode-se dizer, que a natureza no entorno da cidade funciona como uma moldura para o patrimônio histórico e cultural, valorizando-a ainda mais.

Dessa maneira, o Parque Estadual da Serra Dourada é de extrema importância para a manutenção do próprio título de Patrimônio Mundial, pois a UNESCO, hoje em dia, ao 
tombar um sítio, considera os aspectos arquitetônicos, históricos, culturais e ambientais de uma certa localidade, e por isso mesmo, da necessidade do parque ser implantado de fato, o mais rápido possível, para que se possa pensar dentro do plano de manejo um plano de uso público para desenvolver o ecoturismo dentro dessa unidade de conservação, no qual é previsto e definido que áreas poderão ser visitadas e quais os mecanismos para a visitação (uso de veículos, trilhas feitas somente a pé ou se vai ser permitido em algum ponto a visita a cavalo ou de bicicleta, entre outros).

Minha sugestão para o ecoturismo no Parque Estadual da Serra Dourada é inicialmente propor uma gestão compartilhada, ou seja, a Agência Ambiental, que é responsável pela gestão das unidades de conservação do Estado, estar atuando juntamente com outros órgãos no parque. O que quero dizer, é que seria adequado este órgão estar trabalhando com a Secretaria de Educação da Cidade de Goiás, de Mossâmedes e de Buriti de Goiás, com a Secretaria Estadual da Educação, com as escolas municipais, com as universidades, com a AGETUR, com as Secretarias Municipais de Cultura, Meio Ambiente e Turismo, com a Secretaria Estadual da Agricultura, com a SEMARH - Secretaria do Meio Ambiente e Recursos Hídricos, com a Associação de Condutores e Visitantes das cidades, com organizações não-governamentais, e até mesmo, com eventuais empresas privadas que possam prestar algum tipo de serviço dentro da UC.

No que se refere à parceria com as universidades poderia se trabalhar conjuntamente com os cursos de geografia, biologia, agronomia, veterinária, história, antropologia, sociologia e turismo, entre outros. Os profissionais dessas quatro primeiras áreas trabalhariam os aspectos físicos e ambientais da Serra Dourada, fazendo todo um inventário dos recursos naturais da área; também levantando dados necessários para a resolução da questão fundiária, bem como, buscando desenvolver questões relevantes para a adoção e prática de um programa de educação ambiental no parque.

Os acadêmicos do curso de história, sociologia e/ou antropologia poderiam fazer levantamentos sobre a história da região e verificar qual a importância da Serra Dourada dentro desse contexto. Os estudantes dos cursos de turismo poderiam focar nos estudos de mercado; trabalharem diretamente com a comunidade, demonstrando as vantagens e desvantagens do ecoturismo e todas as implicações dessa atividade, bem como, prestarem 
serviços diretamente aos visitantes do parque, com a elaboração de um programa de estágio temporário.

As Secretarias Municipais de Cultura, Meio Ambiente e Turismo, a Secretaria Estadual da Educação, as Secretarias Municipais de Educação e a Secretaria Estadual de Ciência e Tecnologia sendo responsáveis por programas específicos de capacitação dos moradores locais, através do CEP - Centro de Educação Profissional, cuja sede já se encontra no Quartel do XX na Cidade de Goiás. Laboratórios de gastronomia, cursos de guias, cursos de língua estrangeira, cursos de noções de primeiros socorros são apenas alguns dos exemplos que poderão ser oferecidos no CEP.

O desemprego foi uma das grandes reclamações constatadas durante a aplicação dos questionários com os moradores da Cidade de Goiás, e o próprio secretário de turismo da cidade, o Sr. Marco Antônio da Veiga informou-me do desinteresse do jovem da cidade em trabalhar com essa atividade, justamente porque, este não tem espaço. Os profissionais de nível superior não estão sendo aproveitados, por isso, o ideal seria a realização desses cursos de capacitação e a parceria com as universidades, como uma tentativa de aproveitar essa mãode-obra local para o ecoturismo na Serra Dourada.

A AGETUR, outra parceira desejável na gestão dessa unidade de conservação, contribuindo junto à sinalização turística do parque; permitindo também a construção de um Centro de Interpretação da Serra Dourada na Cidade de Goiás, proposta já idealizada pelo Sr. Rodrigo Santana. Esse centro teria todo um acervo de identificação da flora e fauna, permitindo que as pessoas pudessem visitar esse espaço e também conhecer toda a questão ambiental que envolve a serra, mostrando a importância da UC e quais a riquezas que existe ali. Seria também um instrumento a mais de educação ambiental, e ao mesmo tempo, partir daí um estímulo para as pessoas conhecerem o parque. A AGETUR poderia também divulgar o produto Parque Estadual da Serra Dourada, no mercado interno e externo.

A Secretaria da Agricultura e a SEMARH, inicialmente seriam responsáveis pela desapropriação das famílias rurais dentro da área do parque, pois essa categoria de unidade de conservação não permite nenhuma propriedade particular dentro dela. Esses órgãos deverão trabalhar conjuntamente com o conselho gestor do parque. 
A cargo da Associação dos Condutores e Visitantes estaria o cadastro dos guias do parque, bem como, estar verificando a necessidade de cursos de reciclagem profissional para os mesmos. Já as ONGS e as escolas dos municípios trabalhariam com os estudantes, no intuito de conscientiza-los da importância do meio ambiente preservado para as cidades. Enfim, diversas outras instituições e/ou órgãos poderiam fazer parte da gestão compartilhada do parque.

Na verdade, a gestão compartilhada só será possível quando da instituição do conselho gestor, que a meu ver, trata-se da parte mais trabalhosa de todo esse processo, assim como, da elaboração, implementação, execução e monitoramento dos regimentos do Plano de Manejo.

Criado o plano de manejo da área e estabelecendo os atores sociais envolvidos na gestão compartilhada, o próximo passo é estar estruturando o parque de uma infra-estrutura adequada tendo por base o zoneamento, ou seja, estar definido os usos dessas áreas tendo por base as características da localidade, bem como, os serviços necessários para o atendimento à demanda. E, depois de analisada toda a situação, em seguida, o conselho gestor do parque deverá determinar uma situação de turismo desejável e identificar os passos para concretizala, decidindo qual o melhor tipo de turismo para essa área. Por fim, será necessário elaborar uma estratégia e um plano propriamente dito de ecoturismo para o parque.

Dentro do plano de manejo, por exemplo, deverá constar a infra-estrutura necessária; a criação dos sistemas de visitação; um sistema de receptivo de forma a acolher o visitante desde a entrada até a saída; o quadro de funcionários, como forma de trabalhar com uma equipe multidisciplinar; os locais dentro do parque de maiores atrações turísticas; a existência de recursos frágeis e/ou de alguma espécie ameaçada de extinção; os estudos a serem elaborados para quantificar os impactos do turismo e a capacidade de carga da área; a demanda desejada pelo parque; um programa de marketing voltado para a atração de turistas, principalmente aqueles que já freqüentam a Cidade de Goiás; a adoção de programas de educação ambiental tanto para os visitantes quanto para as populações do entorno; um plano de captação de recursos, dentre tantas outras coisas.

Já o Plano de Ecoturismo, poderá ser totalmente viável, como evidenciam os questionários aplicados aos moradores da Cidade de Goiás e aos turistas. Sendo assim, entendo da importância do desenvolvimento dessa atividade estar condicionada ao Projeto 
Caminhos para o Desenvolvimento Sustentável de Goiás, pois por meio desse programa e mediante o intercâmbio e a cooperação técnica entre entidades, instituições empresariais e as micro e pequenas empresas, poderá ser oportunizado um novo mercado com expectativas para formatação de atrativos e/ou implantação e expansão de empreendimentos na cidade e em toda a sua região de abrangência.

A Cidade de Goiás, localizada no ponto central de dois dos caminhos projetados (Brasília - Cidade de Goiás e Goiânia - Aruanã), deve buscar incrementar o fluxo de investimentos no turismo e inserir-se particularmente dentro do Programa Caminhos do Ouro, pois não só a cidade, como todo o caminho trilhado pelos bandeirantes, àquela época, possui potencial turístico que pode ser organizado e disponibilizado, com benefícios diretos no desenvolvimento das comunidades e do Estado como um todo.

Essa monografia empenhou-se em demonstrar a importância da regionalização para o turismo, como é o caso da proposição do Caminho do Ouro para a Cidade de Goiás, entretanto, vale lembrar que essa cidade está na rota do Rio Araguaia, assim, outro roteiro integrado que pode ser desenvolvido para a cidade, é dentro do Caminho do Sol. Conforme o secretário de turismo da cidade, o Sr. Marco Antônio da Veiga, já foi inclusive feita uma tentativa de elaboração da rota (Goiás - Faina - Aruanã), que se mostrou falha, pois as prefeituras municipais não chegaram a nenhum acordo.

Assim, numa visão mais ampla, os municípios devem trabalhar em conjunto, na tentativa de vender apenas um único produto turístico, que nesse caso, é o Roteiro Integrado Caminho do Ouro, ordenamento territorial que já existe no Estado, porém, sem implantação efetiva, já que os municípios ainda não trabalham em parceria de fato.

Uma sugestão seria então a junção do trade turístico de todos esses municípios, ou seja, empresas de meio de hospedagem, de alimentação, de transporte, de recreação, entre outros, deverão, cada qual em seu segmento, procurar desenvolver um plano de Marketing que divulgasse os serviços de todas as cidades, demonstrando que uma cidade está ligada à outra, pela história dos bandeirantes, pela cultura regional, pela culinária local e pelas particularidades de seus ambientes naturais. 
Esse Plano de Marketing deverá conter ações inteligentes que façam os cliente menos sensíveis ao preço, e para tanto, é necessário uma comunicação persuasiva que exerça uma atração no turista, criando neles a necessidade de conhecer não só a Serra Dourada em Goiás, mas também as cachoeiras de Corumbá de Goiás, as cavalhadas de Pirenópolis, as casas seculares de Pilar de Goiás, o pólo de confecção de Jaraguá, o artesanato de Olhos d'Água, as quitandas das várias lanchonetes de Itauçu, os hotéis-fazenda de Alexânia, os produtos rurais como o polvilho e derivados de cana em Itaberaí, e assim sucessivamente. Enfim, existe uma quantidade enorme de atrativos que pode ser desenvolvida com vistas a atrair um número cada vez mais crescente de turistas.

Ações específicas devem ser voltadas para a capacitação de pessoal para lidar com os turistas, já que a vida desses moradores ainda é muito simples, e os mesmos, ainda não possuem um conhecimento verdadeiro do que é o turismo. Ainda hoje, os municípios goianos são muito carentes profissionalmente, e particularmente no que se refere à atividade turística. Esses municípios, por exemplo, necessitam não só de uma oficina participativa uma vez por ano, mas eles precisam de monitoramento e acompanhamento de profissionais habilitados para uma necessária orientação. Essas oficinas participativas são muito importantes, daí a necessidade de ter alguém para continuar o trabalho, iniciado pela facilitadora.

Seria impossível a AGETUR atender todos os municípios goianos, já que, possui 60 funcionários ao todo, tanto na área meio e fim, e por isso mesmo, sendo interessante promover nesses municípios a contratação dos bacharéis em turismo que estão se formando nas faculdades e universidades do Estado. Caso o estado e as prefeituras não disponibilizem sozinhas esse dinheiro, seria viável então, criar um fundo de turismo nessas cidades, fazer parcerias com o convention bureau e com a sociedade civil, como forma de contratar profissionais que iriam pelo menos duas vezes por mês e que passe três ou quatro dias, dependendo da necessidade do município, fazendo esse acompanhamento.

A sinalização ao longo do Caminho do Ouro também é importante como forma de transmissão de informação, bem como, ação indispensável, é o próprio inventário desses municípios.

Preponderante é a criação de uma linha de crédito compensatória, para os empresários que queiram empreender de uma charrete a uma pousada rural, estimulando a formatação de 
produtos turísticos, pois hoje é fato que o Estado não é capaz de bancar sozinho um programa como esse, por isso, a parceria é fundamental para a sua concretização, não me esquecendo de que o zelo pela coisa pública é inerente ao poder público. A gestão do programa como um todo, deve ser de responsabilidade da AGETUR, que poderá apoiar em um conselho consultivo do Programa Caminho do Ouro, dando assento a representantes de diversos outros órgãos, como por exemplo, o SEBRAE, o SENAC, as Universidades, as prefeituras, entre outros.

Quanto mais cidades conhecer dentro desse roteiro e quanto mais atrativos tiver, o turista poderá de fato entender melhor como foi o processo de colonização do Estado de Goiás, pois a característica principal que engloba todos esses municípios é justamente o fato de terem surgido a partir a exploração de seus recursos minerais, principalmente do ouro.

O próprio Programa Estrada Real, desenvolvido nos Estados de Minas Gerais, Rio de Janeiro e São Paulo, hoje é uma realidade de turismo regionalizado, pois esse programa envolve uma totalidade de 177 municípios dentro de um percurso de $1.400 \mathrm{~km}$, por isso mesmo, acredito que o Caminho do Ouro, tomando esse como um exemplo, possa ser desenvolvido como um dos roteiros que venha simbolizar o turismo praticado no Estado de Goiás. Sugiro que representantes da iniciativa privada, de órgãos públicos e até mesmo de organizações não-governamentais realizem viagens até essa região, como forma de conhecerem mais de perto como é desenvolvido o turismo nesses municípios da estrada real.

Essa monografia enfoca a Estrada Real como modelo de turismo praticado de forma regionalizada, entretanto, é bom deixar claro que outros Estados brasileiros já vêem fomentando esse tipo de turismo, como é, por exemplo, o caso do Rio Grande do Sul com o roteiro da Serra Gaúcha, o qual envolve diversos municípios. Na realidade, o ecoturismo no Parque Estadual da Serra Dourada seria então um complemento a mais da visita que o turista realiza na cidade, pois diversos outros produtos poderiam ser formatados também, e dentre eles, o Circuito da Estrada Imperial, uma trilha ligando a Cidade de Goiás ao povoado de Ferreiro e deste ao povoado de Ouro Fino.

Enfim, os municípios unidos em prol do turismo no Estado, permitirão uma maior profissionalização dessa atividade, ainda tão carente em qualidade, e mais ainda, fazendo com que o Estado dê visibilidade à identidade goiana nos planos nacional e internacional. 


\section{CONSIDERAÇÕES FINAIS}

O turismo é um fenômeno que vem atuando como uma forte ferramenta de desenvolvimento econômico e social ao longo dos últimos anos, sendo visto por muitos, como uma forma de aliviar o stress urbano das grandes cidades. E foi exatamente assim, que aos poucos, a atividade foi formando segmentos de consumo orientados pelos diferentes níveis de interesse dos viajantes, como é o caso particular do ecoturismo.

Um dos maiores desafios do ecoturismo é que esta atividade esteja pautada por preocupações de sustentabilidade em longo prazo, ou seja, é tentar operar os produtos em harmonia com o meio ambiente, com as comunidades locais, garantindo também um retorno financeiro satisfatório aos atores sociais envolvidos e atendendo as necessidades dos consumidores, podendo vir então, a ser definido como um tipo de turismo responsável. E uma das maneiras mais prováveis da atuação de um turismo responsável é fazer com que a própria comunidade local tenha o controle da atividade, tanto como implementadores quanto como gestores, entretanto, sem perder de vista a idéia de parcerias.

O objeto de estudo dessa monografia, analisando a viabilidade de implantação do ecoturismo no Parque Estadual da Serra Dourada, é uma tentativa de buscar otimizar o turismo na Cidade de Goiás, por meio da realização de atividades em um ambiente natural. Realmente gostaria que esse parque, segundo maior do Estado de Goiás, fosse um exemplo para as demais unidades de conservação dessa categoria. 
A Cidade de Goiás, apesar de ter melhorado em vários aspectos ao longo desses últimos anos como é, por exemplo, o caso do lixo urbano, muito ainda tem de ser melhorado e trabalhado, e que diferentemente do pessimismo de autoridades locais, que não vê uma situação a curto prazo para o município, eu entendo sim, que a atividade possa ser amplamente melhorada no dia-a-dia.

Essa melhora, é claro, necessitará tanto do apoio do poder público quanto da iniciativa privada. A prefeitura e o Estado devem buscar a atuação conjunta para a melhoria e ampliação da infra-estrutura, pois o secretário de turismo informou-me, inclusive, que o plano diretor da cidade está defasado e antigo, precisando, portanto de estar sendo atualizado, até para a melhora dessa estrutura.

Com isso, ao poder público, tanto municipal quanto estadual compete formular políticas e estratégias que sejam compatíveis com o desenvolvimento sustentável da Cidade de Goiás; garantir a conservação dessa unidade de conservação; adotar e fazer valer os processos de certificação do ecoturismo, como por exemplo, a adoção do selo verde para o parque; estabelecer legislações apropriadas para essa área natural; instituir estudos e pesquisas que sejam relevantes para o interior e entorno do parque; promover programas educacionais voltados ao ambiente natural entre tantos outros.

Outro fator inerente para a qualificação da atividade é a conscientização dos empresários quanto à necessidade de prestação de serviços de qualidade, assim, os profissionais devem ser treinados adequadamente; a associação de artesanato e de guias deve se fortalecer, pois só assim, o município conseguirá de fato beneficiar um maior número de moradores locais e não apenas uma pequena parcela da comunidade; os empreendedores deverão conduzir suas empresas tentando minimizar os impactos ao meio ambiente; deverão procurar trabalhar ativamente com a comunidade local; é necessário que diversifiquem suas ofertas de modo a oferecer atividades variadas.

As organizações não-governamentais, instituições de ensino e associações locais necessitarão cooperar com as organizações públicas e privadas durante o processo de desenvolvimento e gestão do turismo no Parque Estadual da Serra Dourada e a comunidade deverá fortalecer atividades como o artesanato, a culinária, a agricultura e o folclore local. 
Enfim, o ecoturismo no Parque Estadual da Serra Dourada surge então como uma opção de lazer a mais para o turista que freqüenta a cidade e permite à comunidade vislumbrar os benefícios que essa atividade acarreta, principalmente se estiverem participando das tomadas de decisões. 


\section{REFERÊNCIA BIBLIOGRÁFICA}

ANSARAH, Marília Gomes dos Reis. Turismo: segmentação de mercado. São Paulo: Futura, 1999.

BARRETTO, Margarita. Turismo e legado cultural: As possibilidades do planejamento. Campinas, SP: Papirus, 2000.

BARRETTO E BANDUCCI (orgs.). Turismo e Identidade Local: uma visão antropológica. Campinas, SP: Papirus, 2001.

COSTA, Patrícia Côrtes. Unidades de Conservação: matéria-prima do ecoturismo. São Paulo, Ed. Aleph, 2002.

DENCKER, Ada de F. Maneti. Métodos e Técnicas de Pesquisa em Turismo. São Paulo: Futura, 2000.

ÉLIS, Bernardo; MAIA, Tom e MAIA, Thereza Regina de Camargo. Vila Boa de Goiás. São Paulo. Ed. Nacional; Rio de Janeiro: Embratur, 1979.

FILHO, Américo Pellegrini. Ecologia, cultura e turismo. Campinas, SP: Papirus, 1993.

GOIÁS BRASIL - Turismo em Dados: Caminho do Ouro. Agetur, 2002.

IRVING, Marta de Azevedo e AZEVEDO, Julia. Turismo: o desafio da sustentabilidade. São Paulo: Futura, 2002.

LAVILLE, Christian e DIONNE, Jean. A construção do saber: Manual de Metodologia da pesquisa nas ciências humanas. Ed. UFMG, 1999.

LEÃO, Flávio. De volta ta à Estrada Real. Rona Editora.

LIMA, André (org.). O Direito para o Brasil Socioambiental. Instituto Socioambiental: Sergio Antonio Fabris Editor, 2002.

LINDBERG, Kreg e HAWKING, Donald. Ecoturismo: um guia para planejamento e Gestão. Ed. Senac, 2002.

MONTORO, Tânia Siqueira. Cultura do Turismo: desafios e práticas socioambientais. Brasília: Thesaurus, 2003.

MORCELLO, Carla. Áreas protegidas públicas e privadas: seleção e manejo. São Paulo: Annamblume; Fapesp, 2001.

PETROCCHI, Mario. Turismo: planejamento e gestão. Ed. Futura. São Paulo, 2002.

PINTO, Antônio Carlos Brasil. Turismo e Meio Ambiente: aspectos jurídicos. Campinas, SP: Papirus, 1998. 
RODRIGUES, Adyr Balastreri (org.). Turismo e Meio Ambiente: reflexões e propostas. São Paulo, $2^{\text {a }}$ ed. Hucitec, 1999.

SEABRA, Giovanni. Ecos do Turismo: o turismo ecológico em áreas protegidas. Ed. Papirus.

SEBRAE. Apostila Caminhos para o Desenvolvimento Sustentável de Goiás.

SERRANO, Célia M. Toledo e BRUHNS, Heloisa (orgs.). Viagens à natureza: turismo, cultura e ambiente. Campinas, SP: Papirus, 1997.

SILVA, Antônio Moreira da. Dossiê de Goiás. Máster publicidade, Goiânia.

SOUZA, Cibele e CARNEIRO, Maria Esperança F. Retrospectiva histórica de Goiás: da colônia a atualidade. Livraria Cultura Goiana, Goiânia, 1996.

SWARBROOKE, John. Turismo Sustentável: conceitos e impacto ambiental, 2000.

TEIXEIRA, João Gabriel L. C. (org.). Patrimônio imaterial, performance cultural e (re) tradicionalização. Brasília: ICS: Unb, 2004.

UNESCO, Caixa Econômica Federal. Patrimônio Mundial no Brasil. $2^{\text {a }}$ ed. Brasília, 2002.

UNIÃO EUROPEIA/EMBRATUR. Manual de Ecoturismo. 1994.

VIANNA, Gilney; SILVA Marina e DINIZ Nilo (orgs.). O desafio da sustentabilidade: um debate socioambiental no Brasil. São Paulo. Ed. Fundação Perseu Abramo, 2001.

WEARING, Stephen e NEIL, John. Ecoturismo: impactos, potencialidades e possibilidades. São Paulo: Manole, 2001.

WWF. Manual de Ecoturismo de Base Comunitária. 2003

CD-Room - Proposição de inscrição da Cidade de Goiás na Lista do Patrimônio da Humanidade

Sites: Google, Alta Vista, Yahoo, Cadê?, Aonde, MSN Busca.

www.embratur.gov.br

www.mma.gov.br

www.agetur.go.gov.br

www.sebrae.com.br

www.iphan.org.br

www.agenciaambiental.go.gov.br

www.ibama.gov.br

www.estradareal.org.br

www.goias.go.gov.br

www.descubraminas.com.br

www.cidadeshistoricas.art.br 
ANEXOS 
ANEXO 01 - Fotos Parque Estadual da Serra Dourada

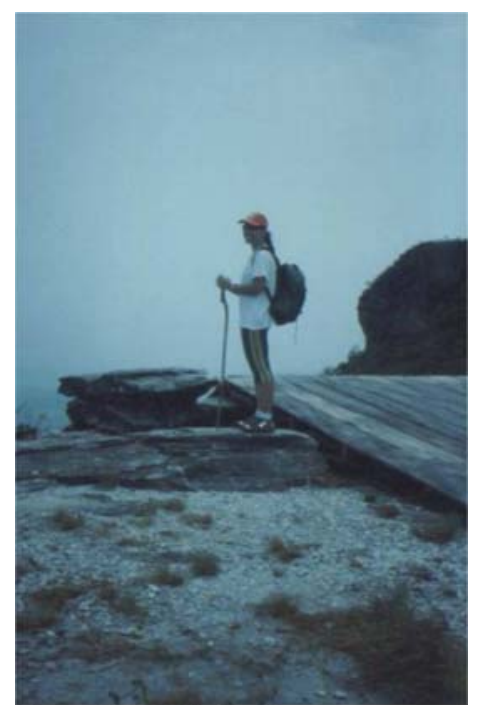

Foto 15: João Luiz

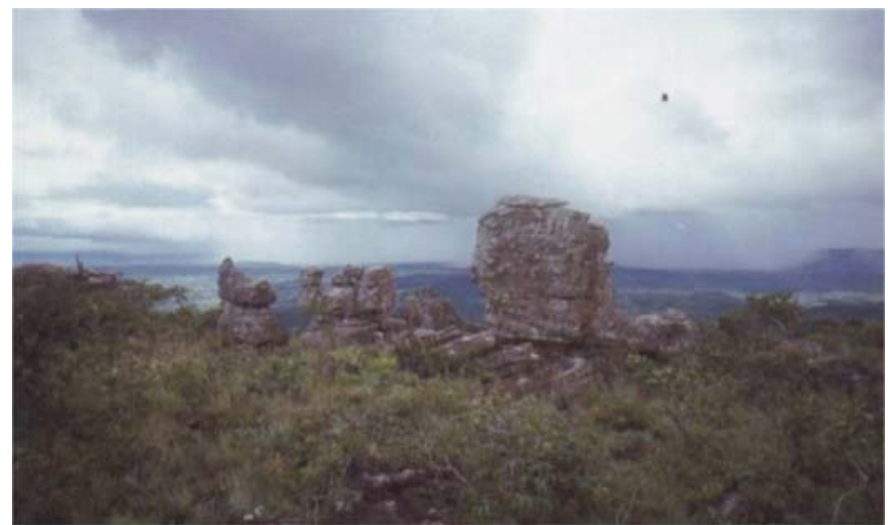

Foto 17: Fernanda Lima

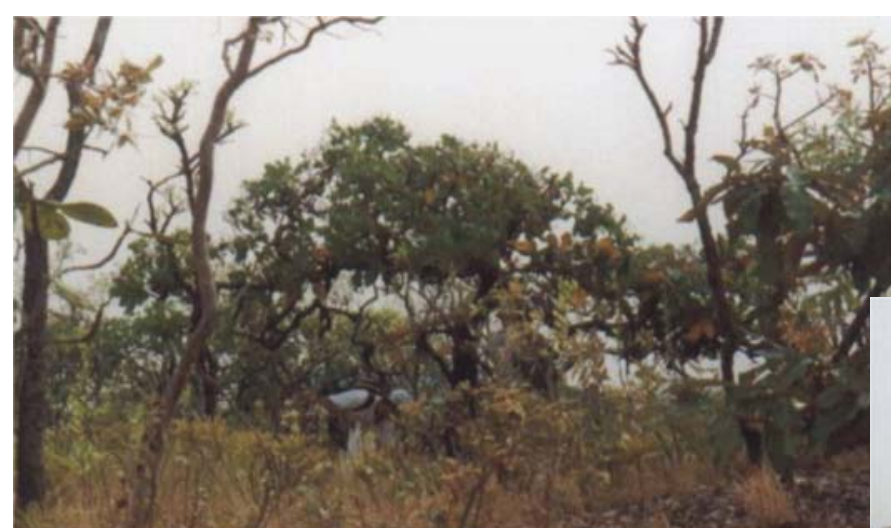

Foto 19: Fernanda Lima

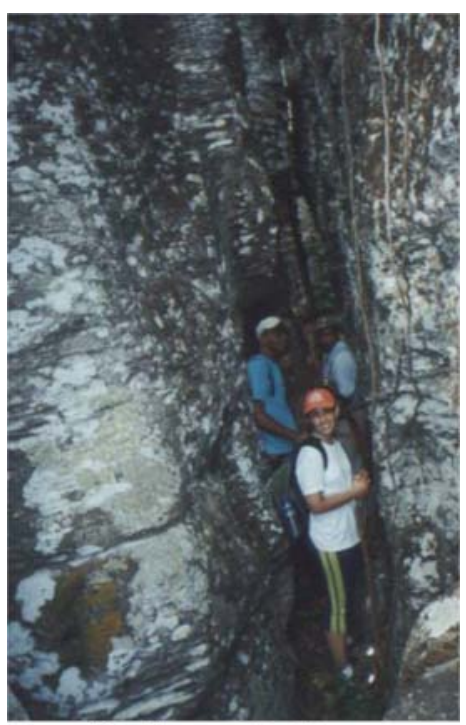

Foto 16: Fernanda Lima

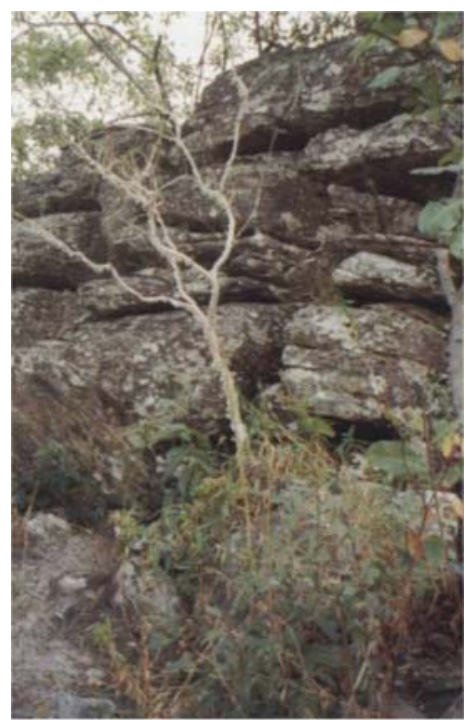

Foto 18: Fernanda Lima 

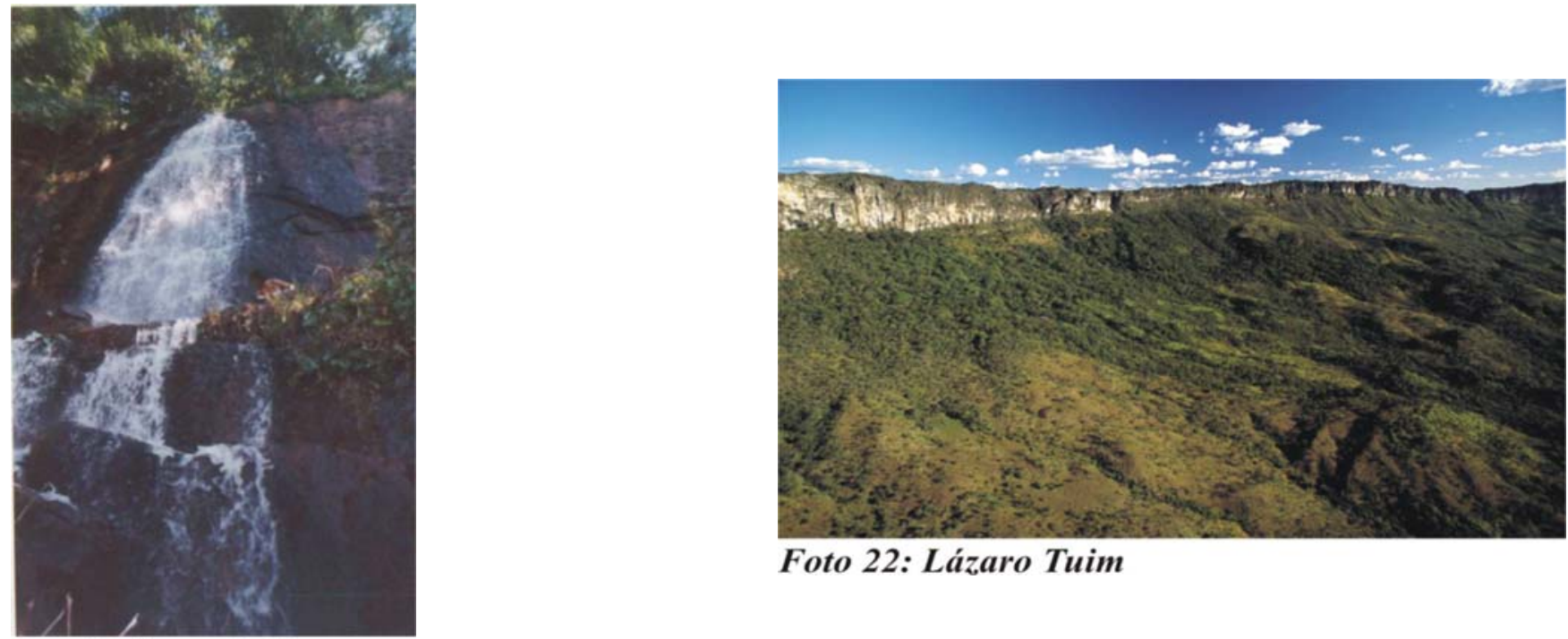

Foto 22: Lázaro Tuim

Foto 21: Fernanda Lima
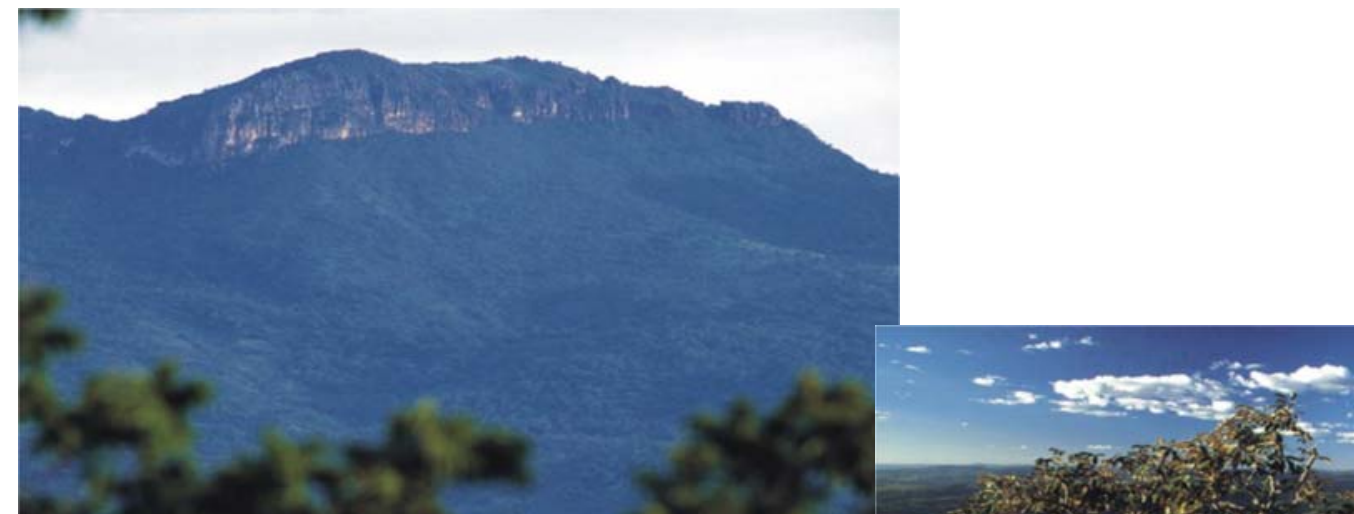

Foto 23: Lázaro Tuim
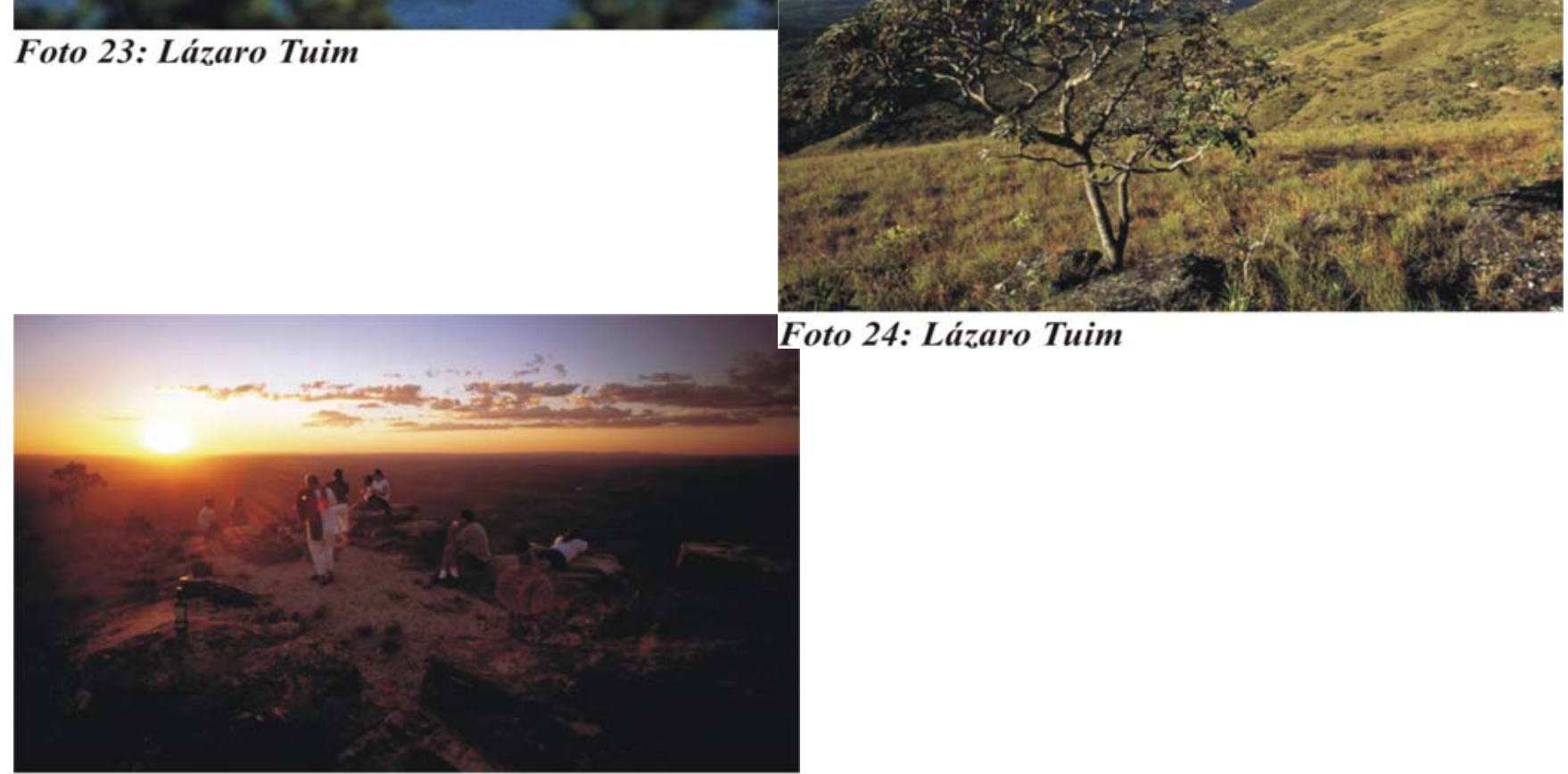

Foto 24: Lázaro Tuim

Foto 25: Lázaro Tuim 
ANEXO 02 - Mapas

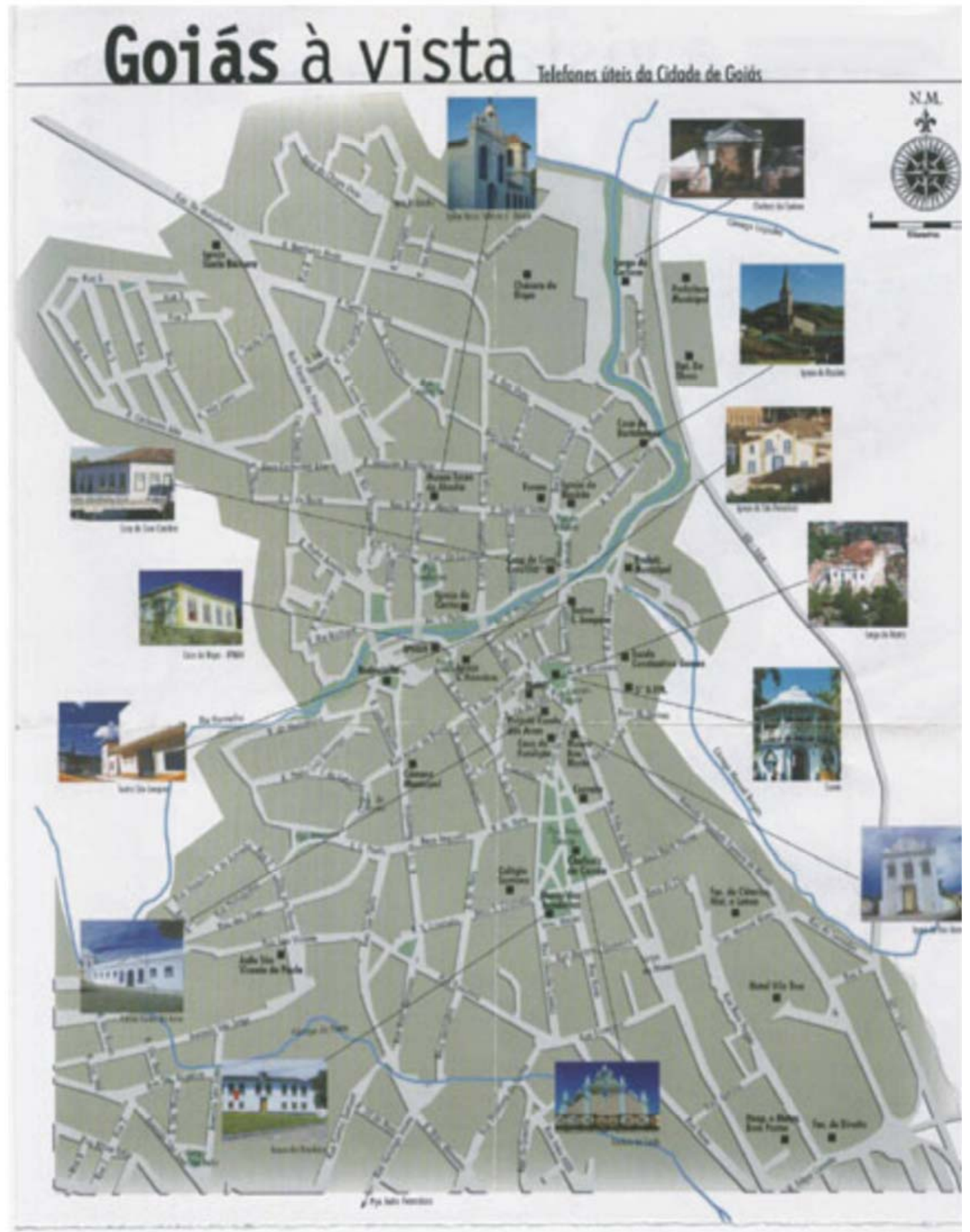

Mapa 01 


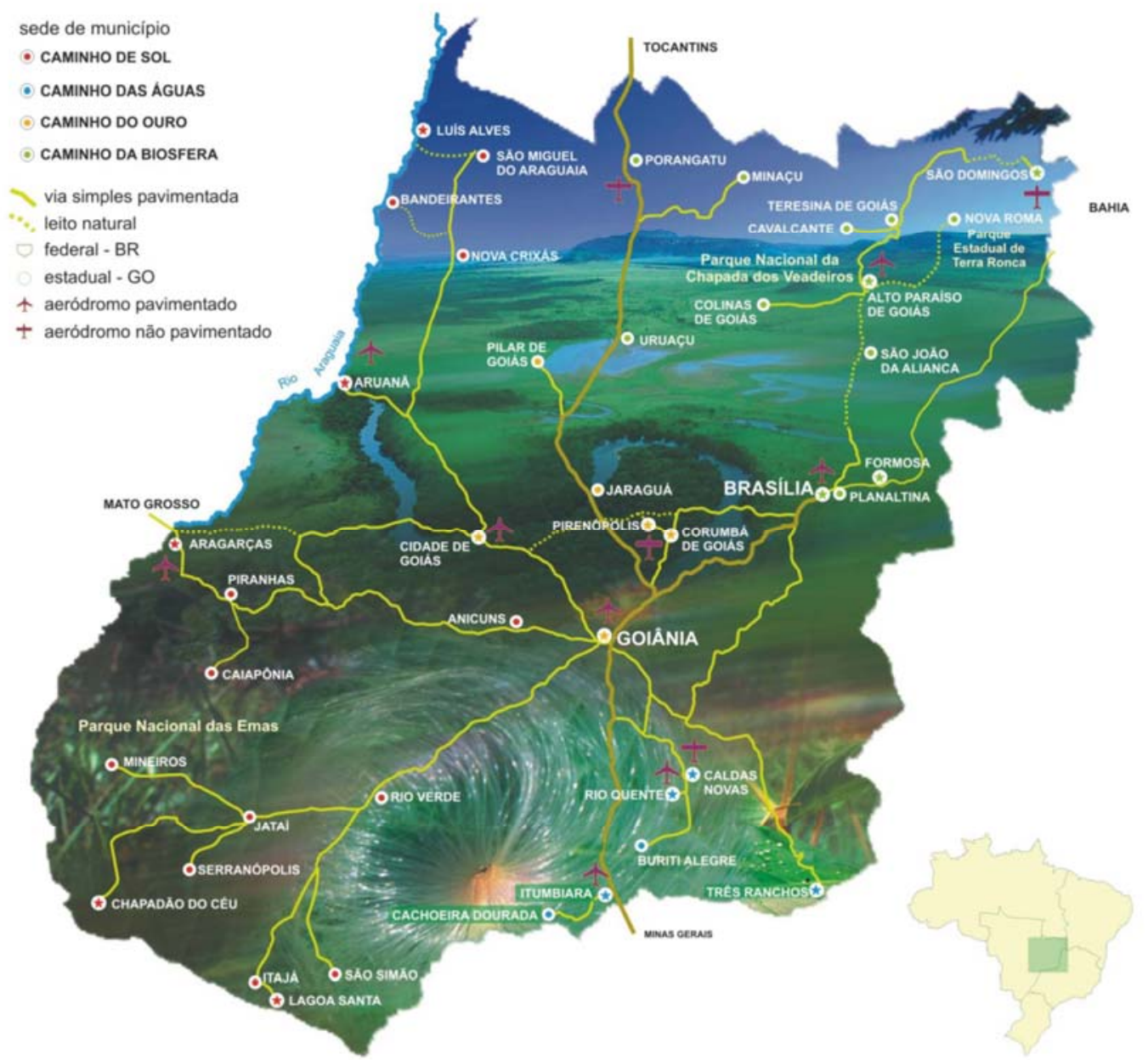

Mapa 02 


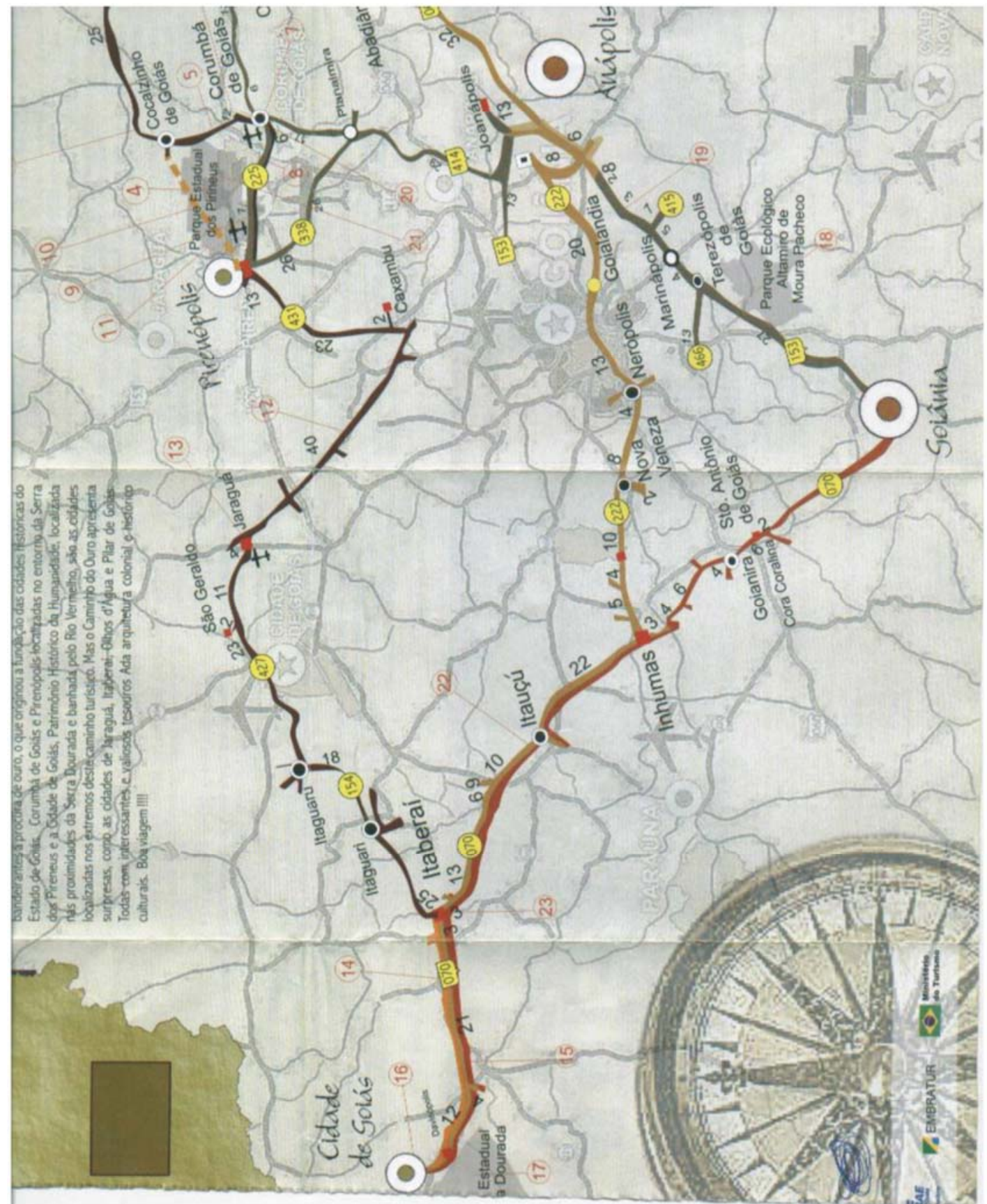

Mapa 03 


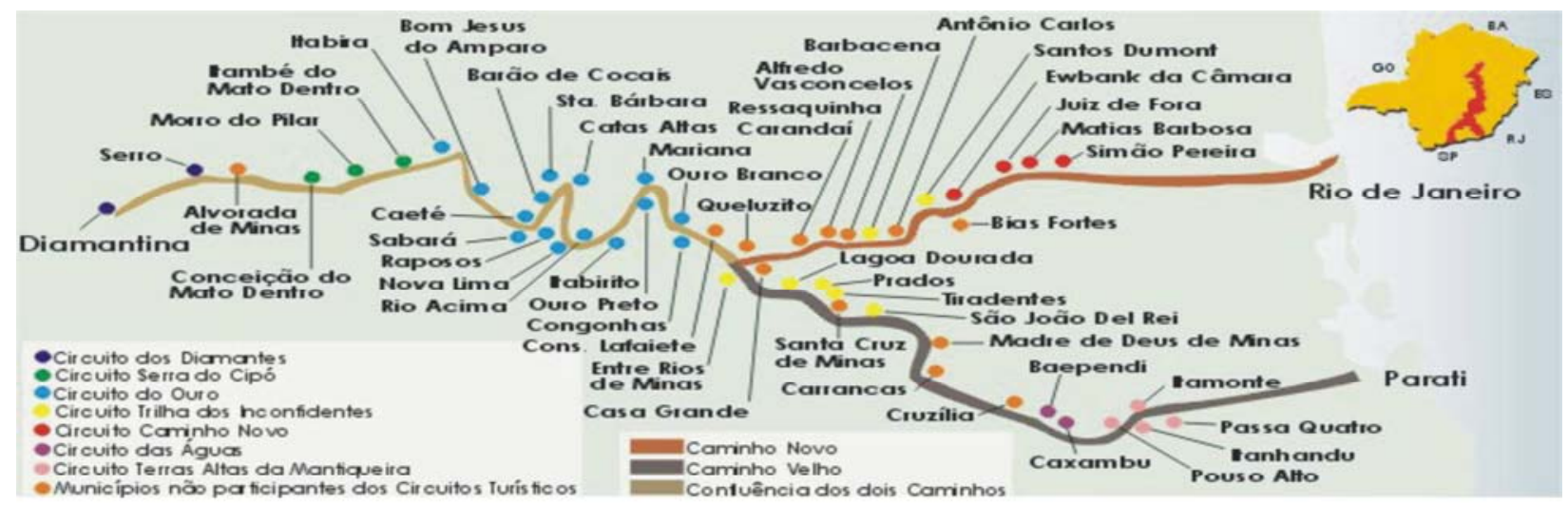

\section{Mapa 04}

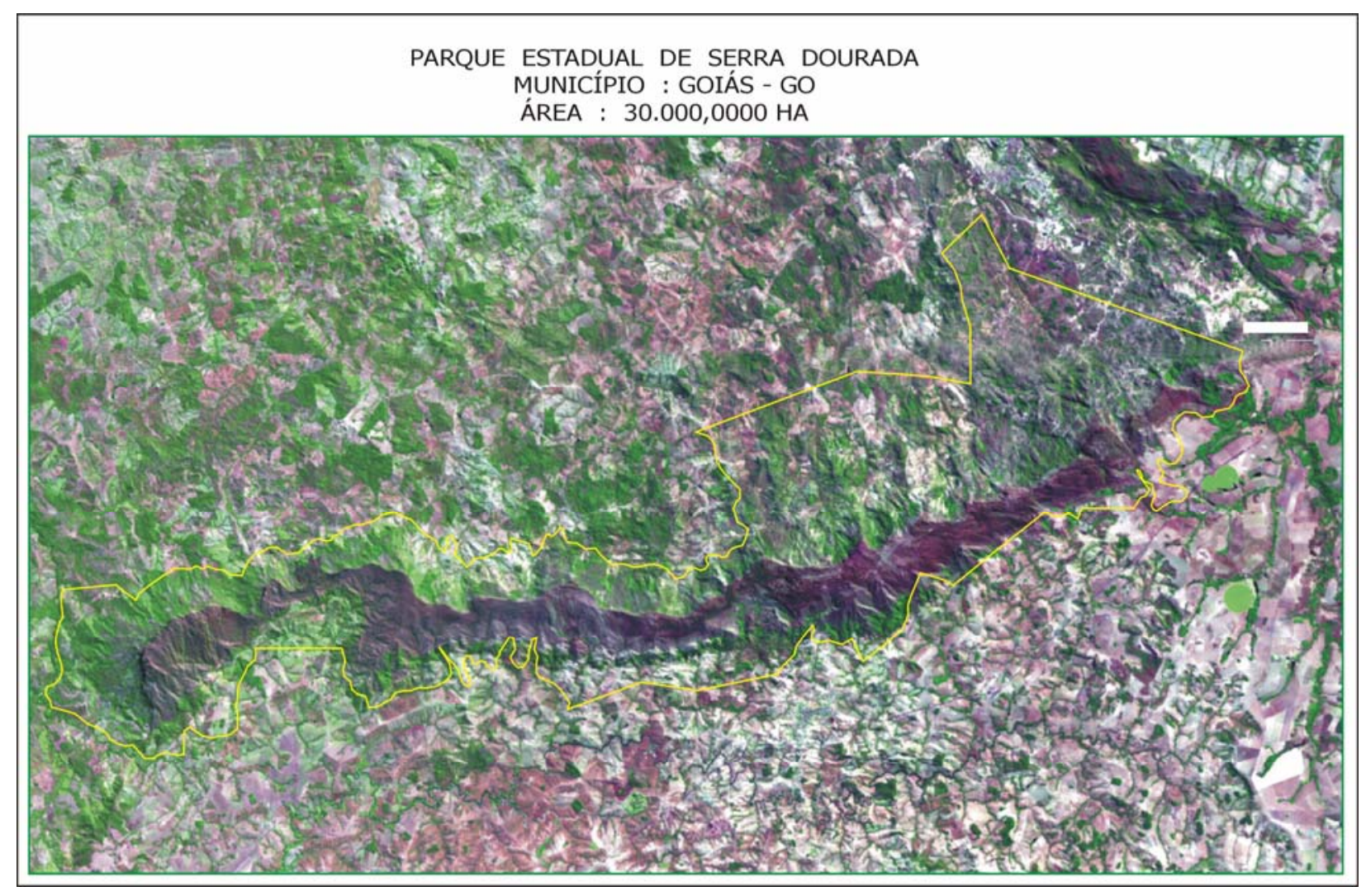

\section{Mapa 05}


ANEXO 03 - Reportagens

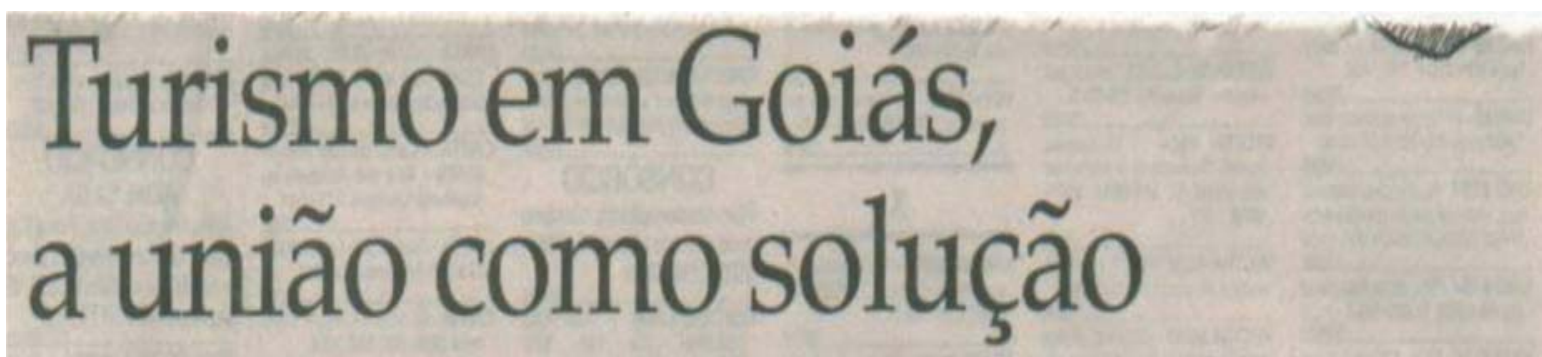

InEvides Joste de Morais Marco ANTónio Gomes Martins

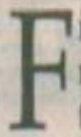
inda a temporada de praias, ca4 minhada ecológica e grande parte do Estado a par dos acontecimentos ao redor do Rio Araguaia, de Caldas Novas, Rio Quente e Chapada dos Veadeiros. Locais que apesar de conhecidos até mesmo fora do País, não são ainda capazes de fazer com que os goianos invistam mais recursos em turismo interno que externo.

Observando outras matérias sobre este mesmo tema neste jornal, pensamos ser uma boa época para refletir sobre o potencial turístico de Goiás. Falamos deste potencial de olho nas estratégias utilizadas por regiốes consideradas exemplos de sucesso neste assunto, comoé o caso da Bahia, Rio Grande do Sul e Ceará. Locais que ao contrário de muitos municípios goianos deixaram de fazer turismo como amadorese adotaram uma estratégia de divulgação turística baseada na parceria entre cidades ou mesmo Estados, que mostram resultados que chamam a atenção, e que com algumas modificaçōes poderiam ser adotadas por Golás.

Ejá que o turismo é considerado pela maioria dos especialistas como uma das principaise mais promissoras fontes geradoras de dividendos do inicio do século 21, este é um tema que deve ser tratado com seriedade.
0 potencial turístico em Goiás vai além dos conhecidos Rio Araguaia, Caldas Novas, Chapada dos Veadeiros, cidade de Goiás e Pirenópolis. Existe boa quantidade de locais com abundância de água doce, cachoeiras, matas e cerrado, apenas superficialmente explorados e divulgados, que podem projetar ainda mais o turismo goiano.

Um dos primeiros passos seria adotar a parceria entre cidades ou regiöes, utilizando como modelo a Bahia e o Rio Grande do Sul, já que lá as cidades se uniram para divulgação do potencial turístico não de uma cidade ou rio, mas de toda uma região, procurando mostrar que as opcôes sảo as mais variadas eestão além da orla martíma.

Assim como o Rio Grande do Sul, Goiás pode ser um Estado não apenas de uma ou duas cidades com potencial turístico bem explorado, mas, com uma rede de cidades e locais capazes de oferecer oppôes de lazer a preços aceitáveis com infra-estrutura que incentive o retorno posterior dos que a visitam devido às suas belezas e qualidade no atendimento. Existe uma série de atrativos em nosso Estado que poderiam ser mais bem aproveitados e ofencidos como uma rede de opcóes interessante em roteiros.

Para isto será preciso abolir a visão (por sinal bastante pequena) de uma cidade que por pouco não entra em guerra aberta com outras na disputa quase que "das sobras" dos turistas de outros Estados. Que em seu lugar seja colocada a associação de cidades, que, em vez de se olharem como inimigas, se vejam como parceiras na divulgaçäo da rede de opçōes turísticas de sua regiāo. Os exemplos do Rio Grande do Sul, Ceará e da Bahia mostram que isto é mais interessante que o turismo localizado em uma só cidade.

Apesar do pouco investimento, 0 programa Caminhos, implantado pela Agetur, que entre outras coisas procura dar uma identidade turística e conhecer o potencial de cada região goiana parece ser um indício (mesmo que tímido) de uma postura mais profissional.

Com a uniảo de cidades em prol do turismo, todos ganhamos. Ganha a população com novos empregos, ganham os municípios e o Estado, que a partir de então poderá contar com maior arrecadaçâo. Façamos com que Goiás ocupe o lugar que merece no turismo brasileiro. O que é bom para 0 Estadoe, consequientemente, bom para o povo goiano.

mEnoes posid ot morus édoutcrando em Socologia pela UnB, mestre em Historia pela UFG e professor da Paculade fadra

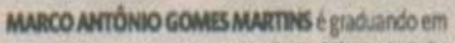
Gestio Ruratica pelocefet

\section{Figura 01}




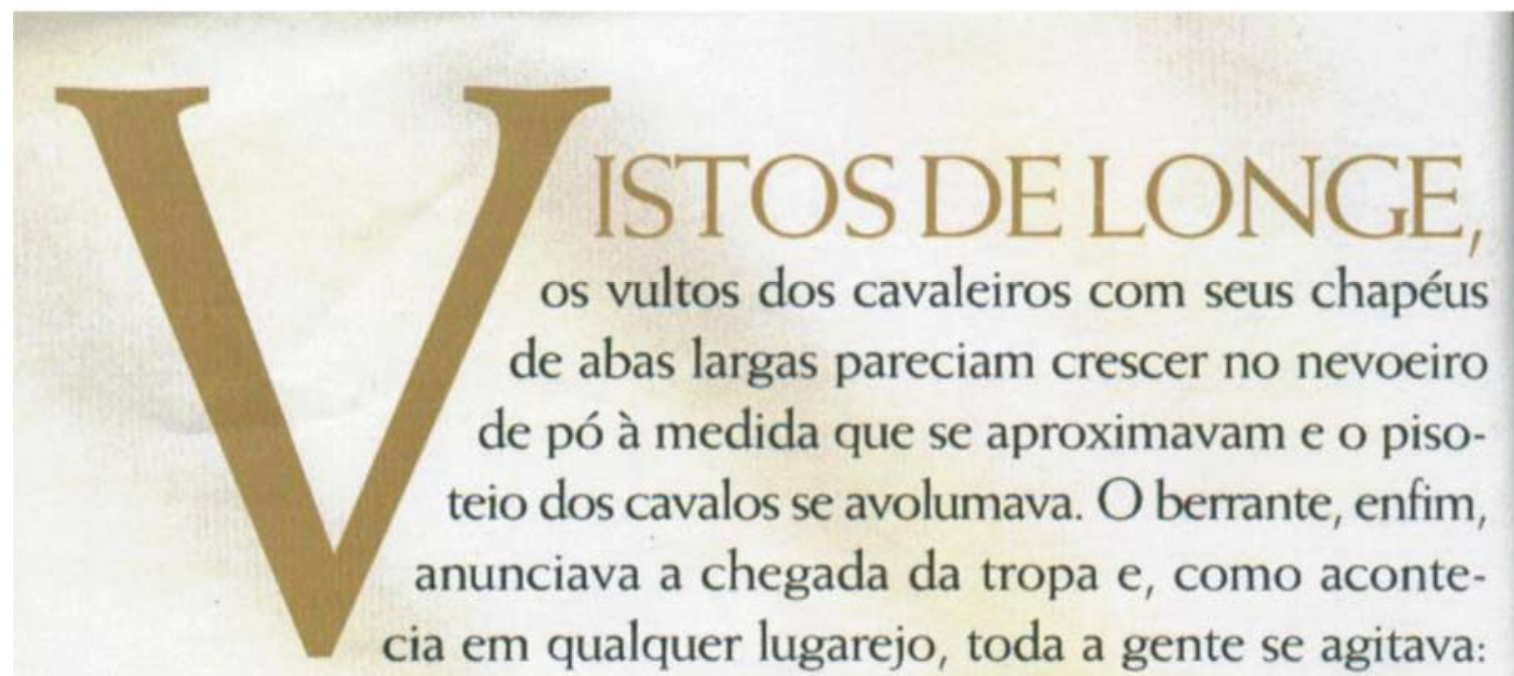

crianças descambavam ladeira abaixo para ver a novidade, enquanto o pessoal mais velho largava o corpo nos beirais das janelas balançando as mâos $\mathrm{em}$ boas-vindas aos forasteiros.

Aos poucos, de forma espontânea, a festa estava formada. Havia burburinho nas ruas $e$ as cozinhas exalavam 0 aroma do frango com quiabo, do angu, do feijão-tropeiro, do café fresco e do doce de leite com queijo. Afinal, fazia muito tempo que Minas Gerais năo via uma tropeirada como aquela. Para os mais idosos, essas imagens dos cavaleiros pareciam saídas da lembrança de um passado distante, um resgate da época em que os tropeiros com suas mulas e mercadorias acomodadas nas cangalhas traziam năo só comida mas também muita história de lugares longínquos.

Dessa vez, porém, aqueles tropeiros formavam uma expediçăo de 26 pessoas, entre cavaleiros e caminhantes, todos pesquisadores - biólogos, historiadores, arqueólogos, téc nicos em turismo, geógrafos, psicólogos, enfim, gente das mais diferentes atividades com um objetivo comum. Eles estavam refazendo os 440 quilômetros da velha Estrada Real, entre Ouro Preto e Diamantina, para garimpar as riquezas culturais, ecológicas $\mathrm{e}$ históricas largadas no fundo do baú de um Brasil que ainda nåo se conhece. Aberto no início do século XVIII, esse caminho foi um veio precioso por onde o país escoou quilates de riqueza em ouro e diamante, o sustento da Coroa portuguesa, dos projetos da revolução industrial inglesa e dos sonhos de Napoleão Bonaparte.

Por 22 dias durante o mês de julho, quando as noites nas montanhas de Minas sào frias e os dias de um calor intenso, o grupo cruzou uma das regióes mais fascinantes do Brasil, onde sobrevive esquecida meia centena de vilas e cidades históricas. A expedição levava o nome Spix \& Martius, em homenagem aos naturalistas Johann Baptiste von Spix e Carl Friedrich Phillip von Martius, dois alemães que em 1817 fizeram o mesmo percurso e catalogaram $40 \%$ da flora conhecida na época, além de detalharem a geografia, a fauna

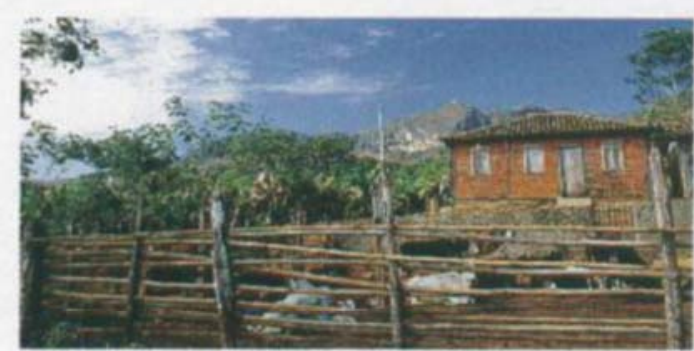

Fazenda em Itambé do Mato Dentro: memória preservada

\section{Eu vivo neste cantinho, onde não bate vento}

nem cbuva. Moro nas locas bá mais de 37 anos." Seu Domingos diz ter 67 anos, habita as cavernas da regiðo de Morro do Pilar $e$, conta, escolheu essa vida errante por causa de uma decepcào amorosa. $O$ ermitła, ao contrário do que pode parecer, nło é uma pessoa tristonha. Alegre, gosta de tocar a viola de uma corda só e conversar com os raros viajantes que cruzam esse trecho da Estrada Real. Emocionado, Domingos "abriu" sua caverna e distribuiu presentes a todos os expedicionários: frutas, păo, qualquer coisa que tinha ao alcance das măos. Um exemplo da hospitalidade que acompanhou os novos tropeiros de Minas.

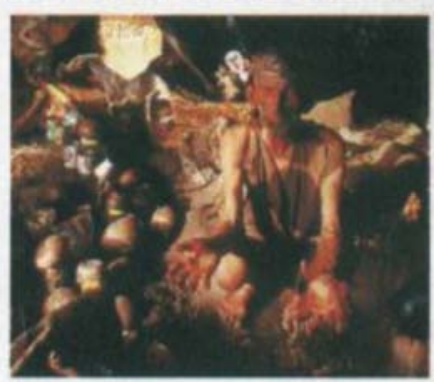

Ermităo das Gerais: seu Domingos vive soxinho nas cavernas que encontra na Estrada na Estra 
e a gente local. O trabalho dessa dupla, que durante três anos viajou pelo interior do país, resultou nos três volumes do livro Viagon ao Brasil.

Assim como os alemães de antanho, os expedicionários de hoje se embrenharam por regiốes de inestimáveis valores histórico e ecológico, como a Serra do Caraça, o Parque Nacional da Serra do Cipó, o Parque Estadual do Pico do ltambé, a Área de Proteção Ambiental das Águas Vertentes e o Vale do Jequitinhonha. Tào deslumbrados e criteriosos em suas anotações como foram Spix e Martius, os pesquisadores - a maioria nascida nas Alterosas - fizeram, no entanto, um trabalho que vai muito além da descriçăo da

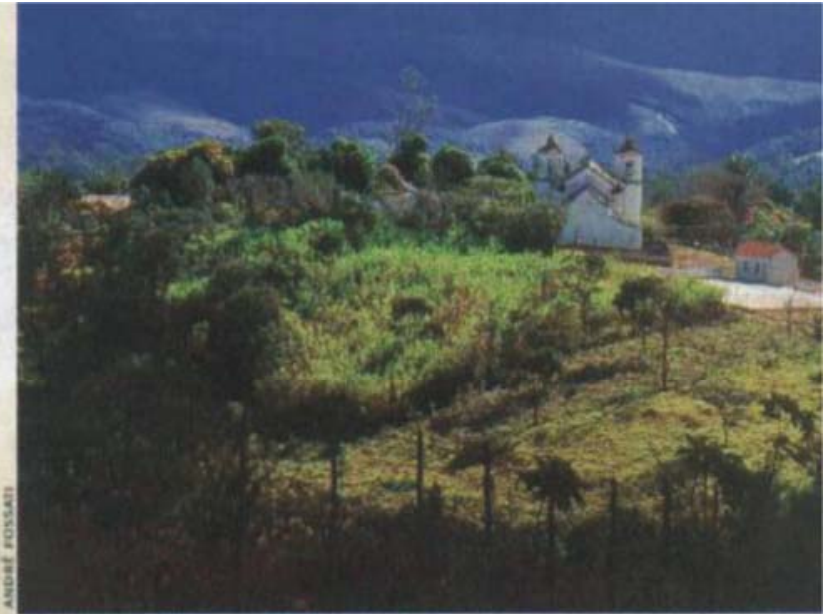

Igreja do Rosário, em Acurul: arte barroca perdida nas serras mineiras

ciso capacitar o povo para receber o turista. O turismo desordenado alteraria a natureza e roubaria um dos mais preciosos tesouros ainda preservados na regiảo: a cultura local."

Uma cultura, diga-se, tão rica quanto a arte barroca de Ouro Preto, as saborosas marmeladas cozidas nos tachos de São Gonçalo, o inigualável queijo do Serro, os finos chapéus de palha trançados nas ruas de Morro do Pilar, as inscriçōes rupestres de Baráo de Cocais, a marujada herdada dos escravos, as serestas, as capistranas e o casario do antigo Arraial do Tijuco - hoje Diamantina, que merecidamente aguarda ser reconhecida pela Unesco como patrimônio da humanidade em dezembro deste ano.

MARCAS DO TEMPO. Ao longo da História, entretanto, os cupins vêm devorando com voracidade esse baú mineiro. A paisagem, por exemplo, alterou-se muito desde que o zoólogo Spix e o botânico Martius percorreram essas trilhas. $\mathrm{Na}$ época, eles descreveram Caeté ("muita árvore", em tupi-guarani) como uma cidade envolta por mata espessa. Hoje, essa mesma região é uma imensidão de pastos, que teve sua floresta transformada, num primeiro estágio, em carvão para alimentar a indústria siderúrgica.

É nas vizinhanças da pequena Caeté, aliás, que a natureza tem sofrido mais. O Rio das Velhas, em Raposos, lím. pido e navegável no passado, agora escorre poluído com existe, tirado de uma pepita encontrada aqui na minba rua." trés tesouros que gosta de mostrar aos raros visitantes do vilarejo. Um deles é o anel de casamento, feito pelo marido em ouro puro, achado no chlo depois de uma chuva, nos anos 40. Outra riqueza é o orquidário, que enfeita 0 amplo quintal com dezenas de espécies (todas catalogadasi) do cerrado mineiro. Mas os olhos de dona Mariinha brilham como um diamante lapidado quando ela mostra a coleçlo inusitada: très centenas de latinhas de sardinha, areadas todos os meses e pregadas, com rara simplicidade, na parede da corinha.
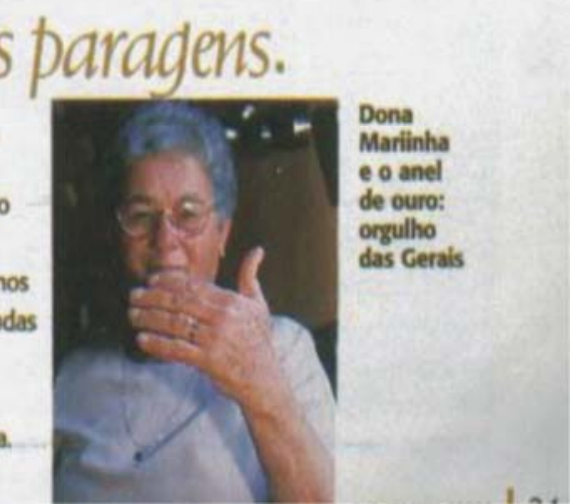


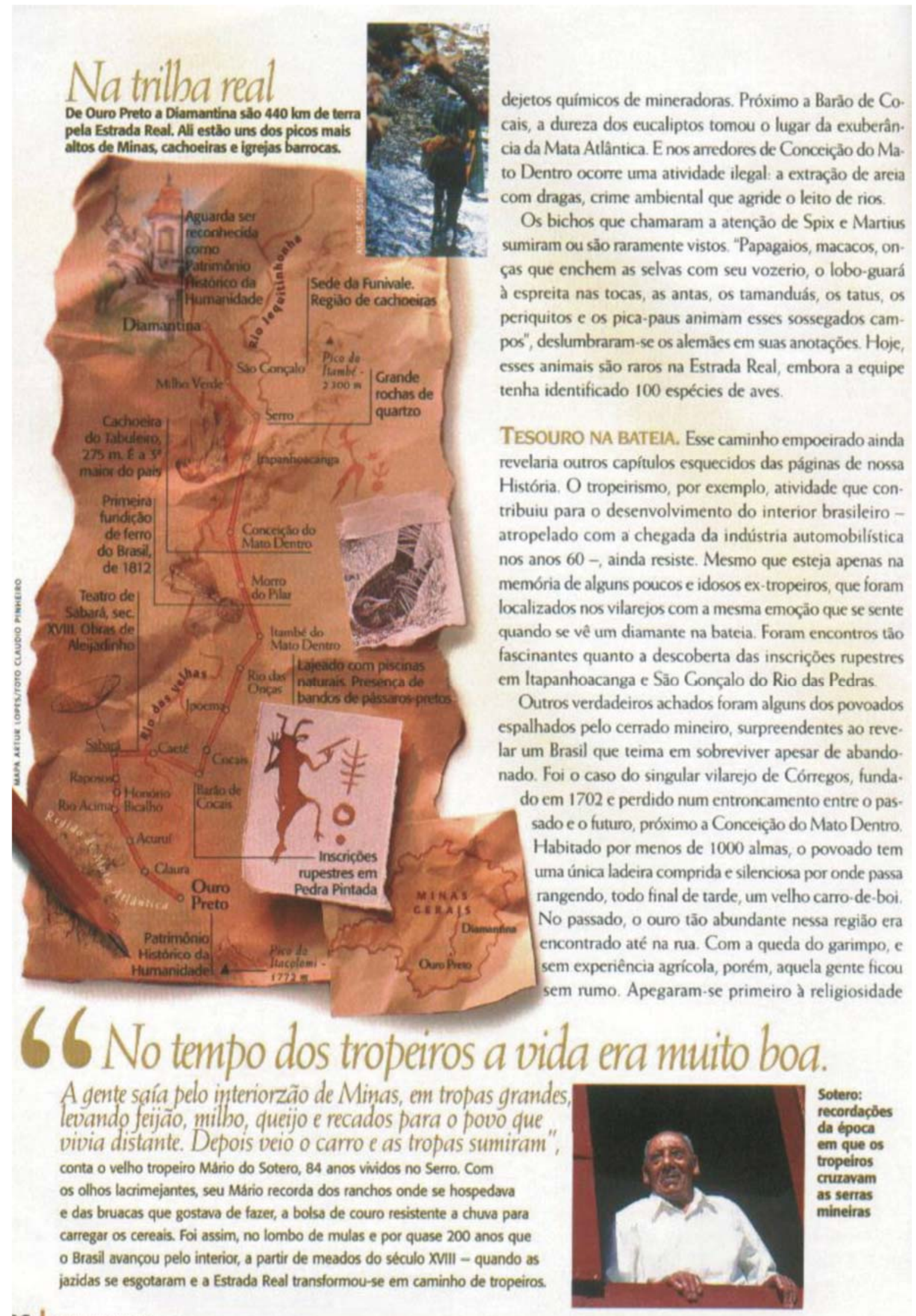

32 | uns answormm 


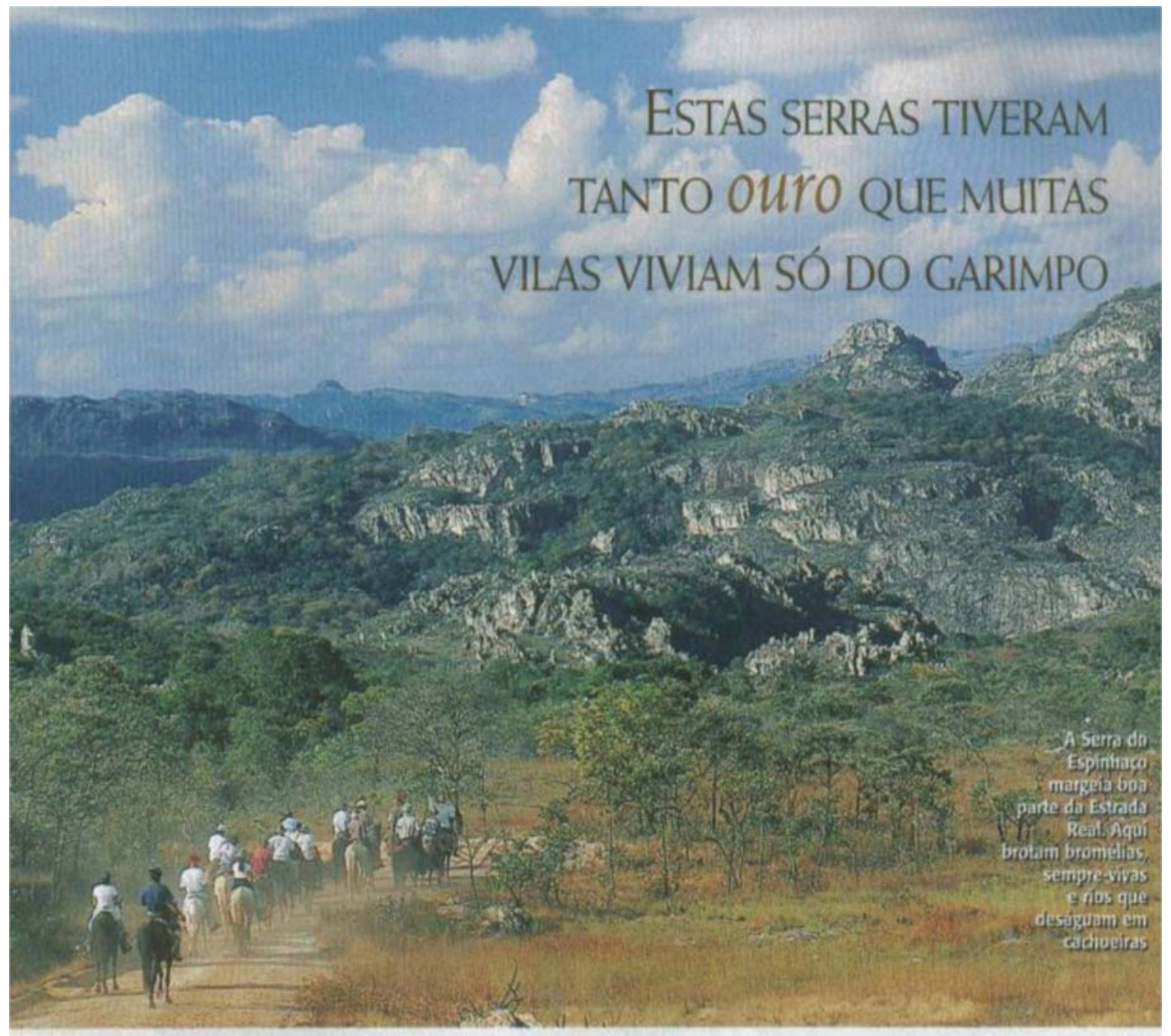

(daqui saíram 22 padres) e, agora, tentam acertar o pé no futuro por meio da cooperativa que planta e produz polpa de frutas, como maracujá, abacaxi e acerola. Única alternativa para que os jovens parem de sair da pequena Cómegos em busca do futuro incerto na cidade grande.

Uma realidade, aliás, compartilhada por boa parte dos povoados da Estrada Real, que ainda vislumbra na migraçăo uma saída para tempos melhores. Para muitos desses lugarejos, a passagem da expediçăo Spix \& Martius trouxe um novo ânimo. Afinal, conforme os planos de seus pesquisadores, a transformaçāo desse velho caminho num des. tino turístico poderá recuperar seu valor histórico e natural, trazendo oportunidades de trabalho e de uma nova vida para essa gente. $\mathrm{O}$ que seria mais do que merecido nesta véspera de comemoração dos cinco séculos de Brasil, onde Minas Gerais, por si só, sáo outros quinhentos. Ii

PARA IR MAIS LONGE

httip://expedicao scriptmaniacom, site da expedicho Spix \& Martius.

Viagens pelo Brasill limo dos naturalistas Spix e Martius, publicado pela editora titatiaia, tel. $0,31 / 222.8630$.

Associaclio Mineira de Ecoturisma, tel $0 \ldots$ 31/282-1320

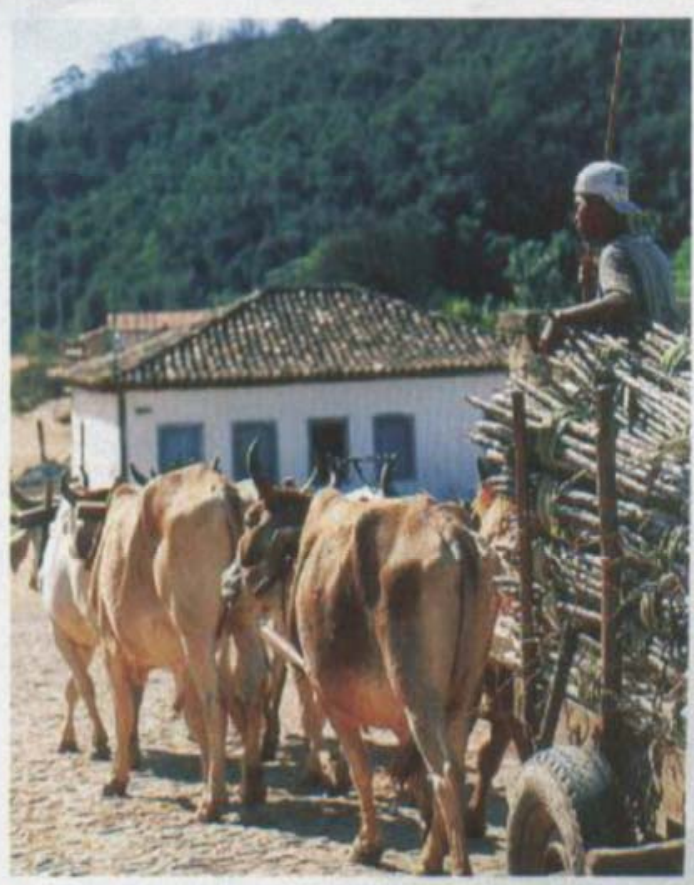

Visão antiga: o carro-de-boi cruxa a pequena Cónregos 


\section{ANEXO 04 - Modelo dos Questionários aplicados}

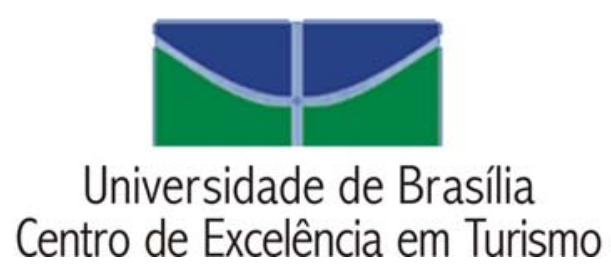

Projeto de Pesquisa sobre a viabilidade de implantação do ecoturismo no

Parque Estadual da Serra Dourada - Cidade de Goiás (GO)

Este questionário visa coletar dados junto aos moradores da cidade, como forma de verificar se são favoráveis ao desenvolvimento do ecoturismo no Parque Estadual da Serra Dourada. Solicitamos sua colaboração a fim de conhecermos suas necessidades e suas sugestões que poderão contribuir para o turismo no estado de Goiás. Agradeço atenciosamente.

01 - Sexo:

( )Feminino ( )Masculino

02 - Faixa etária:

( )menos de 20 anos ( )20 a 25 anos ( )26 a 35 anos （ )36 a 45 anos （ )46 a 55 anos （ )acima de 55 anos

03 - Escolaridade

( )nenhuma ( )ensino fundamental ( )nível médio ( ) superior （ ) pós graduação

04 - Ocupação atual:

05 - Como é ter a presença de turistas em sua cidade? （ )bom （ )ruim

Por que?

06 - O turismo melhorou as condições de vida da sua comunidade?

$\mathbf{0 7}$ - O turismo traz problemas para sua comunidade?

Se sim quais?
( )barulho
( )drogas
( )perda da tranqüilidade
( )impactos ambientais
( )aumento do custo de vida
( )maus costumes
( ) que problemas?
08 - O turismo traz mais benefícios
$\mathbf{0 9}$ - Você já foi na Serra Dourada?
( ) sim
( )lixo nos atrativos/cidade
( )especulação imobiliária
( ) $\operatorname{sim}$ ( )não
( )não

( ) sim

( ) sim

( )não

10 - Qual a sua visão sobre a Serra Dourada?

( )Acredito que a serra é um patrimônio natural e deve manter-se preservada sem a presença do homem pois já foi muito explorada pela mineração durante a colonização.

( )A serra pode ser utilizada apenas como objeto de estudo para pesquisadores.

( )O ecoturismo pode ser desenvolvido na Serra Dourada com práticas adequadas de manejo trazendo benefícios para a comunidade e valorizando ainda mais as tradições da região.

( )Outros

$\mathbf{1 1}$ - O que você acha da implantação do ecoturismo no Parque Estadual da Serra Dourada?
( )ótimo
( )bom
( )regular
( )ruim

12 - Sua comunidade mudaria com a vinda do ecoturismo nesta região?

( ) sim

( )não

Por que?

( )diversificação de serviços

( )geração de emprego

( )mais locais de lazer para a comunidade

( ) trará mais infra-estrutura

( )melhora na qualidade de vida

( )nenhuma mudança significativa

13 - Se você pudesse atuar junto ao desenvolvimento do ecoturismo o que faria?
( )não faria nada
( ) seria contra o ecoturismo
( )estimularia o seu desenvolvimento

( )outros 


\section{4 \\ Universidade de Brasília \\ Centro de Excelência em Turismo}

Projeto de Pesquisa sobre a viabilidade de implantação do ecoturismo no

Parque Estadual da Serra Dourada - Cidade de Goiás (GO)

Este questionário visa coletar dados junto aos turistas que visitam a cidade sobre o interesse em participar de práticas de ecoturismo no Parque Estadual da Serra Dourada. Esta pesquisa será de grande relevância para o turismo no estado de Goiás. Atenciosamente agradeço a colaboração.

01 - Sexo:

( )Feminino ( )Masculino

02 - Estado Civil:

( )Solteiro/a ( )Casado/a ( )União estável ( )Viúvo/a ( )Divorciado/a

( )Outros:

03 - Faixa etária:

( )menos de 20 anos ( )20 a 25 anos ( )26 a 35 anos ( )36 a 45 anos ( )46 a 55 anos ( )acima de 55 anos

04 - Em que estado você mora?

05 - Com quem você está viajando?

$\begin{array}{lllll}\text { ( )sozinho/a } & \text { ( ) )1casal } & \text { ( )grupo de amigos } & \text { ( )casal com filhos } & \text { ( )família } \\ \text { ( )excursão } & \text { ( ) outros_l } & & \end{array}$

06 - Qual seu local de hospedagem?

( )hotel/pousada ( )casa alugada ( ) $2^{\text {a }}$ residência ( )com amigos/parentes

( )camping ( )outros

07 - Qual o tempo médio de sua permanência?
( )de 1 à 3 dias
( ) de 3 à 5 dias
( )de 5 à 7 dias
( ) acima de 7dias

08 - Já visitou este município com objetivo turístico?

( )sim ( )não

Se sim, quantas vezes incluindo esta? ( ) ) 2 $2^{\mathrm{a}}$ visita （ )entre 3 e 5 vezes
09 - Épocas de sua visitação:

( )mais de 5 vezes
( )feriados ( )finais de semana
( )férias
( ) dias úteis

10 - Qual o seu gasto médio diário?

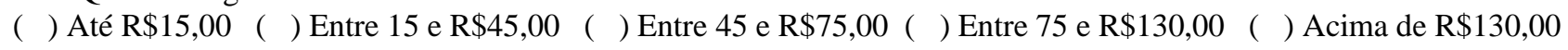

11 - Durante a visita, com quais atividades você se envolve mais?
( )visita a museus/igrejas/monumentos
( )relaxar/descansar
( ) caminhar pela cidade

( )manifestações populares

Se sim qual?

13 - Você já teve conhecimento ou te ofereceram algum passeio na Serra Dourada?

( ) $\operatorname{sim}$ ( )não

14 - O que você acha do ecoturismo sendo realizado dentro de uma Unidade de Conservação (Parque Estadual)?
( )ótimo
( )bom
( )regular
( )ruim

15 - Você gostaria de praticar o ecoturismo no Parque Estadual da Serra Dourada? ( )sim （ )não

16 - Se sim que atividades seriam estas?
( )caminhada
( )cavalgada
( )ciclismo
( ) )observação da fauna/flora
( ) )asa delta

\section{( )outros}




\section{FONTES}

Diagnóstico de criação do Parque Estadual da Serra Dourada -- Agência Ambiental Fotografias tiradas na Cidade de Goiás ------------------ Fernanda Rodrigues de Lima

Fotografias tiradas na Serra Dourada-------------------- Fernanda Rodrigues de Lima Fotografias tiradas na Serra Dourada -------------------------------------- Lázaro Tuim Gráficos de 2002 aplicados na Cidade de Goiás ------------------------------- AGETUR Gráficos de 2004 aplicados na Cidade de Goiás -------- Fernanda Rodrigues de Lima Mapa da Cidade de Goiás -------------------------------------------------- Revista Electra Mapa de delimitação da área da Serra Dourada-------------------- Agência Ambiental Mapa do percurso da Estrada Real ----------------------------------------------- Internet Mapas do Programa Caminhos do Ouro --------------------------------------- AGETUR Questionários aplicados com turistas e moradores ----- Fernanda Rodrigues de Lima Reportagem: No caminho perdido dos velhos tropeiros ------------------- Revista Terra Reportagem: Turismo em Goiás, a união como solução -------------- Jornal O Popular 